\title{
A MONOGRAPH OF THE FORAMINIFERAL FAMILY POLYMORPHINIDAE, RECENT AND FOSSIL
}

\author{
By Joseph A. Cushman, of Sharon, Massachusetts \\ and
}

Yoshiaki Ozawa, ${ }^{*}$ of the Imperial University of Tokyo

\section{INTRODUCTION}

The Polymorphinidae, like many other families and groups of Foraminifera, are in a state of confusion that makes it difficult to identify species on account of the great number of forms figured under the same name. Many names have also been given to the same species. Brady, Parker, and Jones, in 1870, reviewed the subject in their work, A Monograph of the Genus Polymorphina, and Jones and Chapman later dealt at some length with the fistulose forms.

We finished, two years ago, a preliminary study of the family introducing a new classification of the group, based on the relationships as worked out in a joint study of many species. Some of the results of this study have been published: An Outline of a Revision of the Polymorphinidae, ${ }^{1}$ Some Species of Fossil and Recent Polymorphinidae Found in Japan, and A Revision of Polymorphinidae. ${ }^{2}$

Since the completion of the first studies we have both spent some time in Europe studying collections and collecting and preparing material, the results of which are embodied in the present paper after a further six months' study together of the material brought together in our combined collections.

We found that the published figures for the most part were not accurate enough in their details to be reliable in many cases, and except for a study of the available type specimens the study of our own abundant material has been the main source of our conclusions. Nevertheless the type figure and description have been studied in all

\footnotetext{
* While this paper was in press, notice of the death of Doctor Ozawa in Tokyo on December 29, 1929, was received. The correction of proof is therefore entirely mine, with the exception of some few notes I received from Doctor Ozawa after his return to Japan, where he again went over the duplicate manuscript. It is to be regretted that he was not able also to examine the proofs, for his keen mind would undoubtedly have found errors that I have probably overlooked.

Through the characteristic generosity of Doctor Ozawa, my collection at Sharon was made the depository of nearly all the types and slides of all the species and varieties from the various localities. This collection, which will eventually find its way to the U. S. National Museum, is therefore exceptionally complete for this family, which occupies considerably more than a thousand slides and many thousands of specimens.JOSEPH A. Cushmaiv.
}

1 Contr. Cushman Lab. Foram. Res., vol. 4, 1928, pp. 13-21, pl. 2.

2 Jap. Journ. Geol. Geogr., vol. 6, 1929, pp. 63-83, pls. 13-17.

$92709-30-1$ 
cases, usually with a study of topotype material at the same time. We have been exceptionally fortunate in having abundant material from nearly all the important type localities of Europe and elsewhere, so that the species that we have actually seen from their type localities represent a large part of the total number. Many persons and institutions have supplied us with material, and all can not be thanked individually. We have ourselves collected at many of the type localities. In Vienna, for example, Ozawa washed down more than a quarter of a ton of clays from the type localities of Baden and Nussdorf, with the result that we have had for study beautiful suites of specimens of species from these important localities. Of the localities of England, France, Italy, Spain, Belgium, Holland, Germany, Austria, Hungary, etc., we have also had abundant material. From Japan, Australia, Fiji, New Guinea, etc., material has been abundantly supplied as well as from northern South America, Trinidad, Mexico, and the United States. Altogether we have studied material probably from more than a thousand localities, and the number of mounted specimens totals many thousands. We have had for study therefore an exceptional collection, and the results of our study, while not in any sense final, will nevertheless have the satisfaction of being based on abundant material from type localities.

\section{DISTRIBUTION}

In the present work it has been found useless to try to check up the distribution of species from the published records. So many of the species have been wrongly used and so many of the records are unaccompanied by figures that the resulting confusion can only be straightened out by an actual study of the existing collections on which these records were based. Such a study at this time is impossible. For these reasons we have used the specimens available to us and the notes made in studies of European collections.

Even with the many thousands of mounted specimens of Polymorphinidae that we have, it will be found that the ranges both geographically and geologically are probably not entirely correct for some of the species. The distribution of species as we have identified them was plotted in colors on a world map so that the distribution of each species as we have identified it might be quickly seen.

The maps show one thing in particular that was already apparent from our study of many specimens; that is, that smooth, rather primitive species such as Globulina gibba and Guttulina problema have a very long geologic history and are widely distributed. On the other hand, a similar study of the maps of the species of Polymorphina shows that they are each restricted to narrow limits both in present oceans and in the fossil series. In the latter, we are dealing with species of a genus that is specialized and has developed most of its species in the late 
Tertiary and in the present seas. Similarly, it will be found that some of the species of various genera that are highly ornamented or have very characteristic shapes do not range widely, while smooth forms of the same genera for the most part have very much greater ranges. We have recognized this fact, and it is possible in our material to indicate several groups under a single specific name with more restricted ranges, but it was found very difficult to show these differences so that they would be really of use to the worker in the group. Some of these forms undoubtedly overlap in their characters, yet those of given areas or formations may have minor characters which are distinctive when the specimens themselves are studied.

With the smooth Polymorphinidae, especially in the more primitive species of Guttulina, the limits of variation are very difficult to definitely fix, and young stages are also usually perplexing. Forms that seem distinct in two areas may have connecting forms which bridge the gaps, and all are placed together. It will probably be possible with intensive work on restricted areas to definitely fix the limits of variation in different species much more clearly than can be done at the present time.

Microspheric and megalospheric forms, even in the same area or formation, are often considerably different in certain characters, and when the full characters of the two forms are known in each species the distribution will probably be restricted.

Some distributions as shown by well-defined species are very interesting. Some of these are already well known from other groups of the foraminifera. There are, of course, many areas in which there have developed specialized species, very restricted in their distribution and characterizing that particular area or horizon. Many such examples will be found in the species given here, and a few only need be mentioned: Guttulina regina with a restricted Australian-East Indian range, a very striking species difficult to mistake; Polymorphina advena, Oligocene of the Mint Spring marl of Mississippi; P. alleni of the Eocene of England; P. burdigalensis, Miocene of Europe; $P$. complanata, Miocene of Nussdorf; $P$. cushmani, lower Eocene, Midway of Texas; P. frondea, lower Oligocene, Gulf Coastal Plain of the United States; $P$. frondiformis, Pliocene of Sutton, England; $P$. longistriata, lower Eocene, Thanet beds of Pegwell Bay, England; $P$. parallela, Pliocene of St. Erth, England; P. subrhombica, Eocene of New Jersey. These are well-characterized species, and their absence in other regions is due to restricted distribution and not to being overlooked. Some interesting relationships of rather remote regions have been noted. That the lower Oligocene of the Gulf Coastal Plain and the Miocene and living faunas of the Australian region are closely related has been often mentioned. The Pliocene and Recent faunas of the region of Japan and southern 
California are closely related, and a number of species are common to the two areas both fossil and Recent: Guttulina orientalis, Polymorphina charlottensis, and others. The Miocene of the Florida region and that of central Europe have certain species in common. The Eocene of the Paris Basin and allied areas are related to that similar age in America and the Miocene of Australia. The Tortonian Miocene of central Europe is related to the Pliocene of Italy and to the Recent fauna of the Mediterranean. Some of the Oligocene species of Germany are very close to or identical with those of the Cooper marl, upper Eocene of South Carolina, but not equally related to those of the Jackson of the Gulf Region.

An interesting relation is that shown between the living fauna of the Carolina coast and that of the warm area of the Philippines, for example, not in shallow-water forms but in those of a hundred fathoms or more.

The fossil fauna of Trinidad has some very peculiar relationships with those of other regions. Some of the species of the Trinidad Eocene are much like those now living in the Philippine region, and in many respects the fauna has an Indo-Pacific relationship.

The Cretaceous faunas of Europe and America, especially of Mexico and the United States, have much in common. Yet each area in addition to species in common has certain specialized species of its own.

One of the interesting facts in regard to distribution brought out in our studies is the peculiar distribution of Globulina. While the genus was widely distributed in the Cretaceous and early Tertiary, it is much restricted in later times and in the present oceans. Globulina gibba, for example, while it is extremely common through the Miocene, becomes rare in the Pliocene and in the present oceans, not occurring at all in the Pacific and restricted to the Mediterranean and the Eastern Atlantic.

\section{CLOCKWISE OR CONTRACLOCKWISE ARRANGEMENT OF CHAMBERS}

In most of the Polymorphinidae the chambers are arranged, at least in the early stages, in a spiral, quinqueloculine or sigmoid series. In each of these series there are two different plans of arrangement; those are clockwise and contraclockwise. In the present paper a clockwise or contraclockwise arrangement of chambers is used in the sense of the direction in which each succeeding chamber is added when a specimen is viewed from the base. In a spiral species there is no difficulty in determining the direction of the spiral series. In those species having either a quinqueloculine or sigmoid arrangement of the chambers they are separated into two series for purposes of convenience. Therefore in this case the term clockwise or contraclockwise series is based on the direction of the arrange- 
ment of chambers in each series. Accordingly if a species with either a quinqueloculine or sigmoid series of chambers has each succeeding chamber added in a clockwise direction, each of the two series of chambers is directed contraclockwisely, as is shown by the figure.

The question is whether or not the direction of the spiral, quinqueloculine or sigmoid arrangement is fixed in the species. As far as we have examined a great number of specimens of various species, it is fixed in some species, especially those species of more advanced genera, such as Sigmomorphina, Sigmoidella, and Polymorphina.

\section{FISTULOSE OUTGROWTHS}

One of the most interesting peculiarities of the Polymorphinidae is the development of irregular fistulose outgrowths, generally covering the upper part of the test and often extending over the whole surface. It is interesting to note that the fistulose tubes are often rugose, as is the wall of an extra small chamber. The fistulose forms have been treated by some writers as constituting collectively a distinct species or even generic group. Raphanulina, Apiopterina, and Aulostomella are generic names given to fistulose forms. Brady, Parker, and Jones, in their monograph of the genus Polymorphina, unite all fistulose forms and put them in Polymorphina orbignii (Zborzewski), but much later H. B. Brady found that almost all the common species of the Polymorphinidae have fistulose varieties, and expressed the opinion that it appears more natural to assign fistulose modifications to their respective types, and their true position is that of individuals of monstrous development. We are of the same opinion as Brady on these problems, and in the present paper fistulose forms are not separated even as a variety.

The trouble is with the identification of the fistulose specimens, because important characters of the species are often concealed beneath the fistulose outgrowths. Many authors have figured and named fistulose forms, and in most cases the fistulose part is carefully drawn, while the body of the test itself is neglected. Therefore it is very difficult to determine to what species the figured fistulose form is related.

For example, Raphanulina humboldti has well-developed fistulose outgrowths, but it is impossible to determine the arrangement of chambers. Therefore we are compelled to abandon it as a species, although it is described as early as 1834. Many varietal and specific names given to the fistulose forms are omitted in the present paper because of the difficulty in specifically determining them.

\section{ATTACHED FORMS}

Attached forms are not common in the family. Most attached forms are compressed, and the main body of the test resembles some 
particular species. However, in this paper, attached forms are separated from the others.

\section{ORNAMENTATION OF WALL}

Many species in the family have ornamented varieties. Ornamented forms are separated as a variety of smooth forms having the same characters. When an ornamented form is described earlier than a smooth form, the smooth form is taken as a variety.

\section{PHYLOGENETIC RELATION OF THE GENERA OF THE POLYMORPHINIDAE}

The closeness of the relationship between the Polymorphinidae and the Lagenidae is very marked. The wall is similar and especially the terminal radiate aperture. However, the arrangement of chambers is very different from anything seen in the Lagenidae. It is spiral, triloculine, quinqueloculine, or sigmoidal, and in some advanced groups it becomes biserial or uniserial. The most important problem to make clear is how the spiral arrangement of chambers is derived and what the relationship is between various genera with different arrangements of chambers. That is the phylogenetic problem of the Polymorphinidae.

In order to study the phylogenetic relations of various genera of the Polymorphinidae, the detailed examination of the arrangement of chambers of any species is of utmost importance as in other groups of the foraminifera. Excepting d'Orbigny, who gives end views of his earliest species of the family in his Tableaux Methodique, no one has figured end views showing an arrangement of chambers of any species of the Polymorphinidae.

This circumstance caused great difficulties in identification. Some authors considered that the arrangement of chambers of Guttulina is irregular or triserial, but we have examined very many species of Guttulina and have not seen a single specimen having either an irregular or triserial arrangement of chambers. We are convinced that the arrangement of chambers in the Polymorphinidae is very regular and that the family can be divided into several genera according to the various arrangements of chambers as in other families of Foraminifera.

In order to discuss the relationships of various arrangements of chambers, it is of interest to study some typical species of various groups according to their geologic distribution. The geologically oldest species of the Polymorphinidae hitherto recorded are Polymorphina avia and $P$. abavia, both described by Ehrenberg from the Ordovician of the neighborhood of Leningrad. These two species are aggregations of glauconite, and there are some doubts about their organic origin. 
Chapman described two species of Polymorphina, $P$. seminis, and $P$. archaica from the Middle Devonian of Eifel in Germany. They resemble Globulina in their general outline. From the phylogenetic consideration of the family, we doubt if they be true Globulina. No other authors have noted the occurrence of the Polymorphinidae in the Paleozoic rocks.

In the Mesozoic the Polymorphinidae became gradually frequent although most Triassic species are doubtful. Gutiulina (?) raibliana, described by Gümbel from the Upper Triassic of Austria, judged from the figure, surely belongs to the Polymorphinidae. It resembles Guttulina, but the chambers seem to be arranged in a spiral series, as in many of the more primitive Jurassic species.

With the beginning of the Jurassic the Polymorphinidae are of rather frequent occurrence, and more than 50 species are recorded from various Jurassic deposits in Europe. Some of them are identified with Tertiary or Recent species, such as $P$. burdigalensis, $P$. compressa etc., but most of them are known only from the Jurassic. Terquem described most of the Jurassic species from the Oolite and the Lias in France. These Jurassic species are very important for a study of the earlier forms of the Polymorphinidae and its relationships with the Lagenidae. Terquem's figures are probably not drawn well, and no end view showing the arrangement of chambers is given. Ozawa tried to examine Terquem's original specimens in Paris, but it was almost impossible because they are not in good order. Therefore the following discussion of the arrangement of chambers of Jurassic species is according to Terquem's figures with the aid obtained from a study of our Jurassic specimens found in England.

Among Terquem's species, Polymorphina bilocularis is a twochambered fusiform species and is very similar to Vaginulina, but the second chamber more or less deviates from the coiled position of Vaginulina, and is in a spiral position.

Schwager's Globulina secale (1865), in its external appearance, is almost identical with $P$. bilocularis (1864), but it has numerous chambers, most of which are entirely embraced by the last two chambers and are not visible from the exterior. From Schwager's description and figures alone it is almost impossible to determine whether or not the species really belongs to the Polymorphinidae.

Polymorphina intorta Terquem, $P$. nitidiuscula Terquem, and $P$. obliqua Terquem, judging from their figures, may represent intermediate stages between coiled Vaginulina and spiral Polymorphinidae. Their successive chambers are added in planes less than $90^{\circ}$ apart from one another. $P$. sacculus Terquem is a rather interesting species, having three chambers, arranged evidently in a spiral series. Terquem's species Polymorphina triloba, P. breoni, P. polygona, $P$. ovula, and $P$. avena have more than two chambers arranged 
in a spiral series, and each succeeding chamber is removed very much farther from the base. Among them, $P$. polygona is the most interesting, and Terquem put several forms with very different appearances in this species, some three chambered and compressed, the others with an early stage similar to $P$. sacculus. We have a specimen from the Kimmeridge clay in England which is very similar to Terquem's first and second figures of $P$. polygona, and we have identified it with Terquem's species; and it is described in the present paper. In a certain position in side view the specimen is very much like an elongated Guttulina, but the chambers are arranged in a spiral series instead of a quinqueloculine one.

Terquem's species Polymorphina distincta, $P$. amygdala, and $P$. pyriformis are very similar to $P$. polygona in their arrangement of chambers.

From such spiral species are derived elongated forms such as $P$. mutabilis (immutabilis) Schwager, $P$. pyriformis Terquem, $P$. pupiformis Terquem, $P$. ovigera Terquem, $P$. quadrata Terquem, and $P$. distincta Terquem. In these species chambers are arranged in a spiral, and each succeeding chamber is removed much farther from the base, giving to the test an appearance of having a somewhat uniserial or biserial arrangement of chambers.

In such species as Polymorphina cruciata Terquem, $P$. lagenalis Terquem, and probably $P$. squammata Terquem, and $P$. angustata Terquem, the chambers are added in planes $90^{\circ}$ apart from one another, and accordingly they are tetraserial. $P$. irregularis Terquem may represent an intermediate form between such tetraserial forms and the spiral species above referred to. Two such tetraserial forms are reported by Chapman from the Lower Greensand in England (Littleton, Bargate Bed of Surrey). They are Polymorphina rhabdogonioides and $P$. frondicularioides, both of which are figured on Plate 1 of this paper. Chapman added in the description that he thinks that they may represent a new genus or subgenus.

Polymorphina imbricata Terquem is a cylindrical form with chambers seemingly arranged in a biserial series, but we doubt if it is a truly biserial species.

One of the most important groups among the Jurassic Polymorphinidae is that having globular or fusiform species with the sutures not depressed and chambers arranged in a nearly triserial spiral series. In this group are included Polymorphina liassica Strickland, $P$. fontinensis Terquem, Globulina laevis Schwager, Guttulina similis Terquem and Berthelin, and several others. The globular species such as $P$.fontinensis and Guttulina similis are few chambered forms, and in their general outline they are very similar to Cretaceous and Tertiary Globulinas such as Globulina lacrima and G. gibba. But if we examine in detail figures of Jurassic globular forms, we can easily 
recognize the striking difference in arrangement of chambers between Jurassic globular Polymorphinidae and Cretaceous and Tertiary Globulina. For example, we may note Globulina laevis Schwager from the Lower Oxfordian ${ }^{3}$ and Polymorphina gibbosa Terquem from the Fuller's Earth. They are oval forms, having a few chambers which are arranged in a quite different series from the arrangement of chambers in Globulina gibba. In both species each succeeding chamber apparently becomes smaller and smaller, and the chambers are arranged in a spiral series. Such globular, spiral forms are evidently derived from other primitive Jurassic spiral forms by having more overlapping and somewhat regularly triserial chambers.

The fusiform $P$. liassica is also similar to species of Cretaceous and Tertiary fusiform Globulinas such as Globulina prisca and G. minuta in its general outline, and it is apparently impossible to separate them. However, it may be considered that there are probably some globular or fusiform Polymorphinidae in the Jurassic and Cretaceous derived directly from the primitive spiral group.

There is only one species of the Polymorphinidae described from the Jurassic which may be placed under Guttulina with some doubt. That is an ovate, somewhat compressed Polymorphina pygmaea Schwager reported from the lower Oxfordian in Germany. It is quite different from any of the other hitherto known Jurassic species and somewhat resembles Guttulina lactea, but the chambers are arranged in a clockwise series. The biserial species appear also to be rare. Excepting for very doubtful $P$. imbricata, already noted, Polymorphina sinuata Terquem is the only species having a compressed test and biserial chambers. It evidently differs from more advanced biserial Pseudopolymorphina and Polymorphina which are derived from Guttulina and Sigmomorphina, respectively. It may be derived directly from some Jurassic spiral group. Some Cretaceous biserial species such as Polymorphina pleurostomelloides and $P$. gaultina are undoubtedly related to Jurassic biserial forms.

There are some ambiguous species described from the Jurassic, such as $P$. annulata, $P$. oviformis, and $P$. septata, etc. They are either doubtful Polymorphinidae or abnormal species. Spiral and tetraloculine Polymorphinidae seem to have disappeared in the Lower Cretaceous. We have a spiral species from the Gault in England which is new. The two tetraloculine species described by Chapman are also from England.

These primitive Polymorphinidae are replaced by the more advanced Guttulina, which becomes rather common in both Lower and Upper Cretaceous, as do Pyrulina and Globulina as well. Guttulina having the elongate quinqueloculine arrangement of chambers may

${ }^{3}$ Jahresh. Ver. vat. Nat. Württ., vol. 21, 1865, pl. 7, fig. 7. 
be taken as an original stock from which various Tertiary and Recent specialized genera having different arrangements of chambers arose.

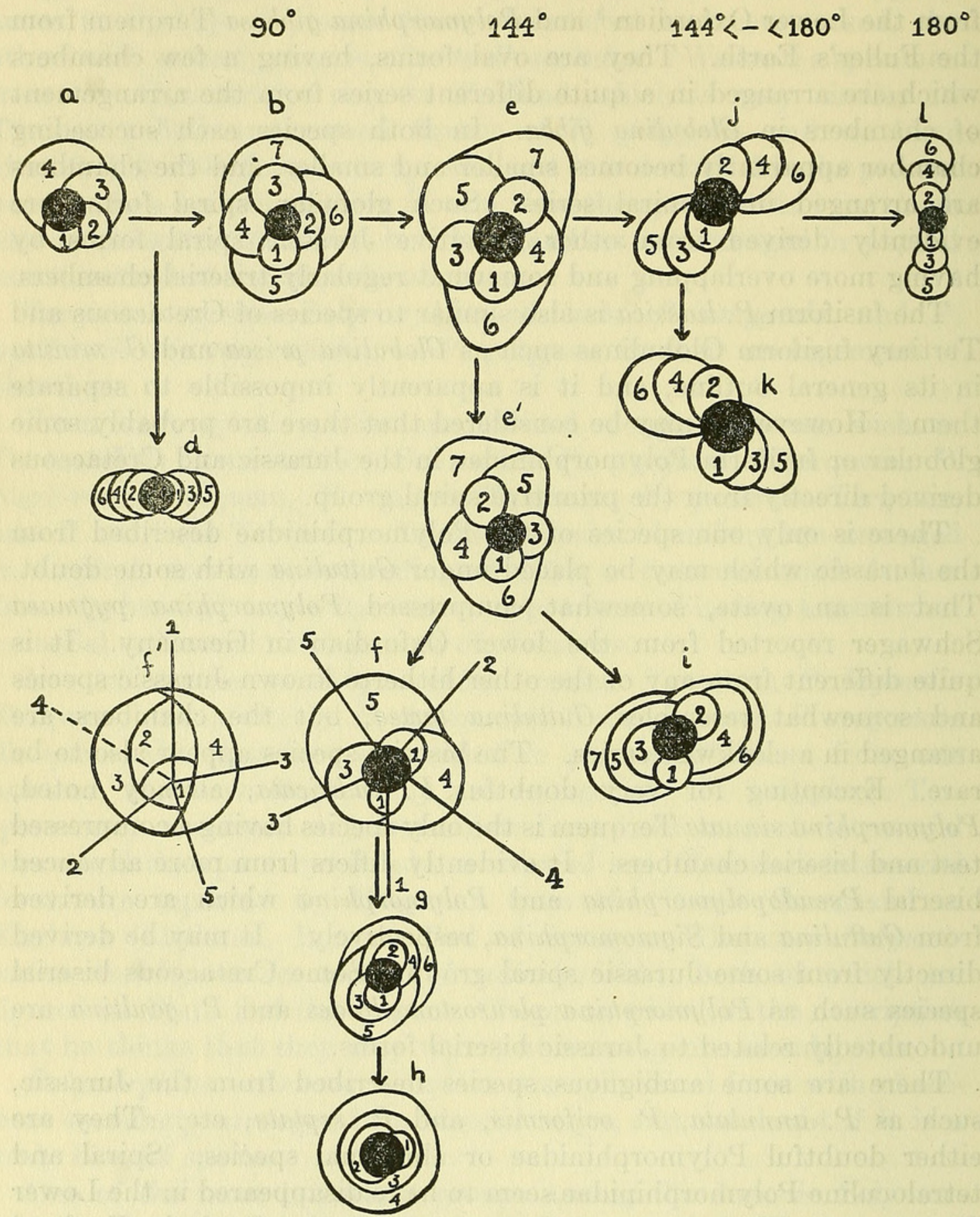

Figure 1.-Idealized basal views of various genera of the Polymorphinidae to show the

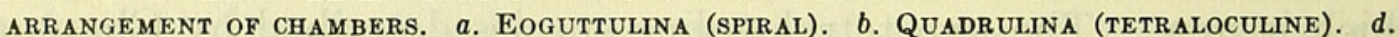

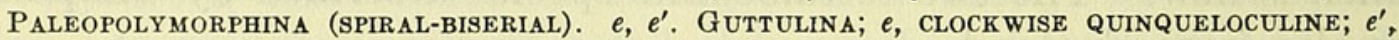
CONTRACLOCK WISE QUINQUELOCULINE. $f, f^{\prime}$. GLOBULINA; $f$, MicrosPHERIC FORM; $f^{\prime}$, MEgALOSPHERIC form. $g$. Pyrulina (QUiNQUeloculine-Biserial). $h$. Glandulina (Biserial-Uniserial). $i$. PSEUdopolymorPhina (QUINQUeloculine-Biserial), $j, k$. Sigmomorphina, Sigmoidella (sigMOIDAL); $j$, CLOCK WISE; $k$, CONTRACLOCK vise. $l$. POLYMORPHINA (EISERIAL)

Guttulina is characterized by a quinqueloculine arrangement of chambers, and each succeeding chamber is added upwardly, so that all apertures are directed toward one end. Its chambers are added in planes $144^{\circ}$ apart from one another. 
Globulina has apparently triserial chambers. However, the actual arrangement is not triserial but somewhat quinqueloculine. The apparent triserial series of chambers has resulted from much overlapping of the chambers as shown by the text figures.

Pyrulina is an elongate or fusiform genus, in which the chambers are typically quinqueloculine in the early stage, later becoming biserial. As is already noted, it is very difficult to separate some Tertiary and Recent species of Globulina and Pyrulina from some Jurassic globular or fusiform species because of their homeomorphy or parallel evolution.

Pyrulina and Globulina are abundant in the Upper Cretaceous, Eocene, Oligocene, and Miocene. In the Pliocene and Recent, they are of rather rare occurrence compared with other genera.

Glandulina, as far as its genotype species Glandulina laevigata is concerned, is closely related to Pyrulina and should be included in the Polymorphinidae. The microspheric form of Glandulina laevigata has the early chambers invariably arranged in a biserial series, although in the later stage and also in the megalospheric form the septa are almost horizontal and parallel.

In the Upper Cretaceous Pseudopolymorphina is introduced. It has a test with the early chambers arranged in a quinqueloculine series, while the later ones become biserial and the chambers are slightly overlapping.

Much more advanced genera such as Sigmomorphina, Sigmoidella, and Polymorphina appear for the first time with the beginning of the Tertiary. Sigmoidina is a group having a quinqueloculine arrangement of chambers as in Guttulina, but each succeeding chamber extends down to the base and embraces the earlier ones, so that but a few chambers are visible from the exterior.

Sigmoidella is undoubtedly related to Sigmoidina, and the chambers are involute, but they are arranged in an open sigmoid series.

Sigmomorphina arose from Guttulina s. str. by developing elongated chambers added laterally in a sigmoid series. In some elongated Sigmomorphina each succeeding chamber in the later stage is removed much farther from the base. Sigmomorpha, the genotype species of which is $S$. sadoensis, is included in Guttulina, after the detailed examination of numerous species, although some specimens show a more or less sigmoid arrangement of chambers.

Polymorphina is the most advanced and specialized genus. The primitive forms have a sigmoid arrangement of chambers in their early stages, but the advanced species are entirely biserial, and each succeeding chamber is farther removed from the base.

Dimorphina tuberosa seems to us to be a very doubtful species. Ozawa found that the original specimen has been lost, and the figures 
of the species given by Fornasini are evidently a Marginulina. ${ }^{4}$ Two species of Dimorphina described from the Vienna Basin by d'Orbigny are also Marginulina with coiled chambers in their early stage.

Therefore Dimorphina is a very uncertain genus. We have a few specimens having the early chambers arranged in a quinqueloculine or somewhat triloculine series, later becoming uniserial. Such forms correspond somewhat with the supposed Dimorphina, but provisionally we have included them in Pseudopolymorphina, from which they are undoubtedly derived by adding chambers in a uniserial arrangement.

Dimorphina compacta described by H. B. Brady, Parker, and Jones from the Crag of Sutton is an arcuate species resembling Marginulina. It does not belong to the Polymorphinidae.

In the following is summarized the evolution of the Polymorphinidae from the standpoint of the changes in arrangement of the chambers.

1. Some doubtful species of the Polymorphinidae are recorded from the Palaeozoic as far back as the Ordovician, but undisputed species belonging to the family are known only from the Triassic and later formations.

2. The Polymorphinidae are undoubtedly derived from some coiled form of the Lagenidae such as Marginulina or Vaginulina by introducing a spiral arrangement of chambers. The family may be divided into the following groups based on the differences in the arrangement of the chambers:

a. Chambers arranged in a spiral series added in planes less than $90^{\circ}$ apart from one another, each succeeding chamber removed farther from the base.

Eoguttulina.

This group is the most primitive among the Polymorphinidae and is known from the Triassic, Jurassic, and Lower Cretaceous of Europe. Provisionally we include in the group those forms having the spiral chambers added in planes more than $90^{\circ}$ but less than $144^{\circ}$ apart from one another.

$b$. Chambers added in planes $90^{\circ}$ apart from one another, that is, arranged in a tetraloculine series at least in the later stage................ Quadrulina.

This group is also known only from the Jurassic and Lower Cretaceous of Europe.

c. Chambers added in planes $120^{\circ}$ apart from one another, that is, arranged in a spirally triloculine series. Chambers more or less overlapping, giving the test a globular or fusiform appearance. This group should be studied in detail. At present we include the group in Eoguttulina because of its spiral arrangement of chambers.

$d$. Test with the early chambers spiral, later ones becoming biserial.

Paleopoly morphina.

$e$. Chambers more or less elongated, added in planes $144^{\circ}$ apart from one another, that is, the chambers arranged in a quinqueloculine series. This group is subdivided into two divisions-one, Guttulina s. str. in which each succeeding chamber is removed farther from the base; the other, Sigmoidina, in which normally each succeeding chamber entirely embraces the earlier ones of its series.

\footnotetext{
4 Mem. Acca 3. Sei. Istit. Bologna, ser. 5, vol. 8, 1900, p. 35, fig. 39.
} 
A quinqueloculine arrangement of chambers seems to be rather stable in the family, as Guttulina is known from the Jurassic (?) and is rather common in the Cretaceous, especially in the Upper Cretaceous, and very abundant in various Tertiary deposits as well as Recent forms throughout the world.

$f$. Chambers, in the early stage of the microspheric form, arranged in a quinqueloculine series, later much overlapping, becoming apparently triserial, that is, chambers added in planes more than $144^{\circ}$ and less than $180^{\circ}$ apart from one

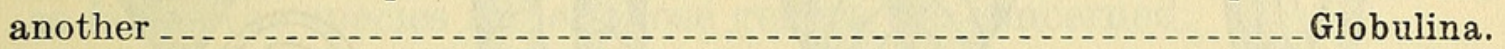

g. Chambers invariably more or less elongated and embracing, arranged at first in a somewhat quinqueloculine series, later becoming biserial_.... Pyrulina.

$h$. Early chambers added in a quinqueloculine or biserial manner, later ones

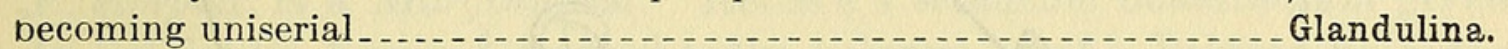

This group is of rather rare occurrence in the older Tertiary, but common from the Miocene to the Recent.

$i$. Early chambers in a quinqueloculine series, later each succeeding chamber farther removed from the base, becoming biserial and in some cases uniserial.

Pseudopolymorphina.

The supposed Dimorphina is provisionally included in the present group.

Pseudopolymorphina occurs in the Cretaceous, but not as commonly as in the Tertiary and Recent.

$j$. Test at least in the adult with the chambers added in planes slightly less than $180^{\circ}$ and more than $144^{\circ}$ apart from one another, each succeeding chamber

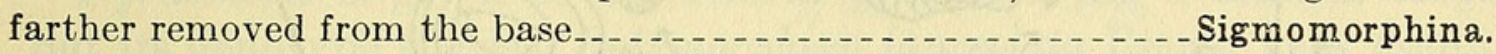

This group is derived from Guttulina and is known only from the Tertiary and Recent.

$k$. Chambers arranged as those of the preceding group, but each succeeding chamber embracing the earlier ones of its series. It is derived from Sigmoidina and is known from the Tertiary as well as Recent.............. Sigmoidella.

$l$. Test with the early chambers arranged in a sigmoid series becoming biserial or entirely biserial from the start. This is the most advanced group among the Polymorphinidae and the chambers are added in planes $180^{\circ}$ apart from one another. It is only known from the Tertiary and Recent. It must be kept in mind that even though it may be made up of an entirely biserial series of chambers the test has an appearance of a slightly sigmoid arrangement of the chambers continuing the shape of its ancestral development........... Polymorphina.

\section{BRIEF NOTES ON VARIOUS GENERIC NAMES GIVEN TO THE POLYMORPHINIDAE}

There are not so many generic names given to various groups of the Polymorphinidae. De Montfort's three genera, Arethusa, Misilus, and Cantharus, are so very rough and ill drawn that they are recognized with difficulty as belonging to the Polymorphinidae, notwithstanding evidence of their having been copied from Soldani's plates. Arethusa is given to the figure copied from Soldani's figure $n n$ (misprinted L L by de Montfort) in Plate 107, and Misilus is considered by Parker and Jones to be used for a globular fistulose form. While Cantharus (seventy-fifth genus) is a very inaccurate copy of Soldani (Testaceogr. pl. 107, fig. $r r$, misprinted $p p$ by de Montfort), Parker and Jones compared Soldani's figure with 'Polymorphina lactea.' 


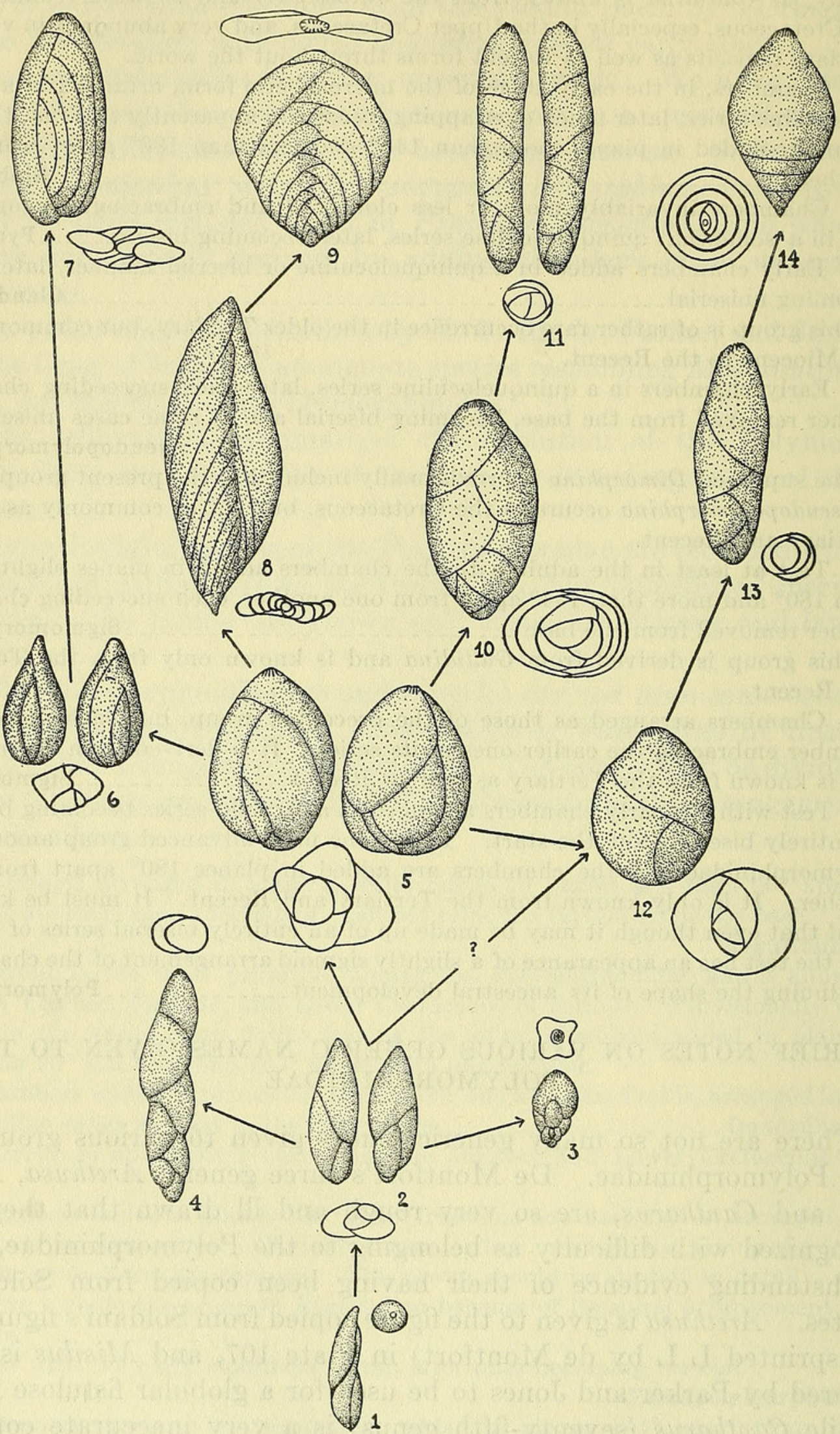

Figure 2.-Development and Relationships of the genera of the Polymorphinidae. 1, 2. Eoguttulina. 3. Quadrulina. 4. Paleopolymorphina. 5. Guttulina. 6, 7. Sigmoidella. 8. Sigmomorphina. 9. Polymorphina. 10, 11. Pseudopolymorphina. 12. Globulina. 13. Pyrulina. 14. Glandulina 
Arethusa was used by Fleming, Bowditch, and Thorpe, but the other two genera were abandoned for a long time. At present no one uses any of Montfort's three generic names because of their poor and rough illustrations. To the fistulose forms three different generic names were given. Those are Zborzewski's Raphanulina and Apiopterina and Alth's Aulostomella, which are included in Globulina, as far as the species under those genera are concerned.

Psecadium is said to have been used by Reuss in manuscript, but it was used for the first time by Neugeboren in 1856. Its first species, P. simplex, is a Marginulina. Reuss's Psecadium acuminatum given to Schlicht's figures ${ }^{5}$ undoubtedly belongs to the Polymorphinidae and is considered by us as a synonym of Glandulina.

Von Schlicht's Rostrolina is considered by Brady, Parker, and Jones to be placed under Polymorphina, but as is already discussed by Silvestri, most of its species belong to the Ellipsoidinidae, and the first species of Rostrolina, according to A. Silvestri, is Ellipsopleurostomella rostrata. The first species of Atractolina is named by Reuss Psecadium acuminatum.

Pyrulinella is given to a fusiform group having a biserial stage, but its genotype species, Polymorphina lanceolata Reuss, very doubtfully belongs to the Polymorphinidae, and it resembles Virgulina, and accordingly the name is dropped and the fusiform group having a biserial stage is placed under Pyrulina.

Dimorphina is an ambiguous genus, although it has been used since d'Orbigny established it. D'Orbigny's species, Dimorphina tuberosa, considered from Fornasini's figure, is a Marginulina. Most species hitherto described under Dimorphina can be placed in other genera.

SPECIES DESCRIBED AS BELONGING TO THE POLYMORPHINIDAE BUT NOT ACTUALLY POLYMORPHINIDAE

There are many species which are described under the Polymorphinidae but actually do not belong to the family. D'Orbigny's Polymorphina acuta and $P$. digitalis, both described from the Vienna Basin, have been recognized by later authors as good species but they are Virgulina (original and paratype specimens examined by Ozawa). Reuss's $P$. lanceolata is used often by later authors, but the first figured specimen appears to belong to Virgulina.

Costa from 1856 to 1864 described fifteen species of the Polymorphinidae. There are two under Polymorphina, seven under Guttulina, five under Globulina, and one under Aulostomella. His Polymorphina is Virgulina, his Guttulina and Globulina are mostly Bulimina,

6 Foram. Septar. Pietzpuhl, 1870, pl. 25, figs. 1-10. 
and one Aulostomella (A. dorsigera) appears to belong to the Polymorphinidae.

Ehrenberg described very many species of Polymorphina which were examined by us at the Museum of Natural History in Berlin, but most of them are mounted in Canada Balsam, and it is very difficult to determine them. Ehrenberg placed under Polymorphina various biserial forms such as Virgulina and Bolivina, but there are none of his species which can be considered with confidence to belong to the Polymorphinidae. Therefore we omitted his species.

Miller's three species of Polymorphina are apparently glauconitic nodules with cracks and not recognizable. Polymorphina complexa Sidebottom from the Kerimba Archipelago has the same arrangement of chambers as Guttulina, but it has pores along the suture lines, and the aperture is quite different from any genus of the family. It may be a new genus belonging to some other family.

Silvestri described one new species and two new varieties from the Pliocene at Coroncina. His Polymorphina pliocaena and its variety tricostata are evidently young specimens of Robulus. $P$. oblonga var. fistulosa is a fistulose Guttulina.

There are still many doubtful species of the family which are not treated in the present paper: as, d'Orbigny's Polymorphina irregularis (1839), $P$. rochefortiana, and many others.

\section{Genus EOGUTTULINA Cushman and Ozawa, new genus}

Test with the chambers arranged in a spiral series added in planes less than $90^{\circ}$ apart from one another, each succeeding chamber removed farther from the base.

Genotype.-Eoguttulina Anglica.

EOGUTTULINA ANGLICA Cushman and Ozawa, new species

Plate 1, figures $3 a-c$

Test elongated, more or less cylindrical, the greatest breadth in the upper half, obtuse at the base, acuminate toward the apertural end; chambers somewhat longer than broad, inflated, not much embracing, arranged in a spiral series, each succeeding chamber much farther removed from the base; sutures depressed, distinct; wall smooth; aperture radiate.

Length $0.65 \mathrm{~mm}$.; breadth $0.28 \mathrm{~mm}$.

Holotype.-(Cushman Coll. No. 10990.) From Cretaceous, Cambridge Greensand, Saxon Cement Works, Cambridge, England.

In a certain position in side view, Eoguttulina anglica resembles some elongated forms of Guttulina. Each succeeding chamber is removed farther from the base, as in an elongated Guttulina, but the chambers are arranged in a spiral series and not quinqueloculine. 
EOGUTTULINA LIASSICA (Strickland)

Plate 1, figures $2 a-c$

Polymorphina liassica Strickland, Quart. Journ. Geol. Soc., vol. 2, 1846, p. 30 , fig. $b$ (in text).

Polymorphina metensis Terquem, Quatr. Mem. Foram. Lias, 1864, p. 301, pl. 13, figs. 38a,b.-Terquem and Berthelin, Mém. Soc. Géol. France, sér. 2, vol. 10, pt. 3 , 1875, p. 68, pl. 6, figs. $1 a-j$.

Globulina laevis Schwager, Wurttemberg, Naturwiss. Jahreshefte, vol. 21, 1865 , p. 137 , pl. 7 , figs. 5,25 .

Test elongated fusiform; chambers few, elongated, embracing, arranged in a triserially spiral series, each succeeding chamber removed farther from the base; sutures not depressed, distinct; wall smooth; aperture radiate.

Length $0.35 \mathrm{~mm}$.; breadth $0.15 \mathrm{~mm}$.

The present species was described by Strickland from the Liassic formation at Wainlode Cliff, Gloucestershire, England. We have a single specimen from the Liassic in Gloucestershire which is very similar to Strickland's species in general aspect. The only difference is that our specimen is slightly more slender.

In general outline it is very similar to the Cretaceous Globulina prisca, and it is almost impossible to separate them at a glance. The arrangement of chambers is seemingly different, that of the present species being spiral from the first chamber, while in that of Globulina prisca the first chambers are completely surrounded by the following ones. This may be a primitive form of an elongated Globulina, but for the present, we prefer to place it in Eoguttulina.

Polymorphina metensis described by Terquem from the Middle Lias of Saint-Julien-les-Metz and also by him with Berthelin from the Lower Lias of d'Essey-les-Nancy seems to be very close to the present species, although its chambers are much more embracing.

Globulina laevis from the Jurassic in Germany has a small $(0.3 \mathrm{~mm}$. in length) fusiform, slightly compressed test, and in its general features it is very similar to the present species.

Polymorphina oolithica from the Jurassic of Conflans and Fontenoy resembles the present species in general outline, but it is compressed. It may be different from the present species.

Distribution.-All the records of this species are from the Jurassic.

\section{EOGUTTULINA POLYGONA (Terquem)}

Plate 1, figures $1 a-c$

Polymorphina polygona Terquem, Quatr. Mém. Foram. Lias, 1864, p. 305, pl. 14, figs. 16-20, 21-41(?).

Test somewhat compressed, elongated, acute toward the apertural end; chambers longer than wide, more or less triangularly compressed, arranged in a spiral series, each succeeding chamber farther removed $92709-30-2$ 
from the base; sutures depressed, rather distinct; wall smooth; aperture radiate.

Length $0.33 \mathrm{~mm}$; ; breadth $0.12 \mathrm{~mm}$.

We have one specimen from the Kimmeridge Clay in England which is very similar to Terquem's figures of few chambered specimens.

Terquem's Figures 16-20 appear to be very similar and may be included in the present species, but as to the others, it is doubtful whether or not they are the same as the present species.

Distribution.-Terquem reported it from the lower Lias at Beauveau and Auline in France.

\section{Genus QUADRULINA Cushman and Ozawa, new genus}

Test with the chambers added in planes $90^{\circ}$ apart from one another, that is, arranged in a tetraloculine series, at least in the later stage.

Genotype.-Quadrulina rhabdogonioides.

\section{QUADRULINA RHABDOGONIOIDES (Chapman)}

Plate 1, figures $4 a, b$

Polymorphina rhabdogonioides Chapman, Quart. Journ. Geol. Soc., vol. 50, 1894, p. 716, pl. 34, figs. $12 a, b$.

"Test subpyramidal and quadrifacial; bluntly pointed at the base and rapidly increasing in width toward the oral extremity. The test is smooth and consists of a Polymorphine series of chambers (slightly twisted as regards the commencement), the margins of which are deeply sunken, and the chambers themselves, numbering about five to seven on each face of the test, well inflated, especially in the case of the more or less central one visible on each face. The terminal chamber is large and embracing, subquadrangular in section, but not regular. The aperture is circular and with margin pectinate.

"Length one-seventieth inch $(0.36 \mathrm{~mm}$.); width diagonally one one hundred and tenth inch $(0.23 \mathrm{~mm}$.).

"The foregoing species is probably a dimorphous form, combining Polymorphina with Rhabdogonium, and in the event of other varieties becoming known it may be found necessary to form a distinct genus for this type.

"Two specimens from the pebble beds, Littleton, Bargate Bed of Surrey (lower greensand)."

We have no specimen of this species. The above is quoted directly from Chapman, and the figures are copied from his plate.

From Chapman's figures and description the present species seems to have the chambers arranged in a spiral series in the early stages, later becoming tetraserial. 


\section{QUADRULINA FRONDICULARIOIDES (Chapman)}

Plate 1, figures $5 a, b$

Polymorphina frondicularioides Chapman, Quart. Journ. Geol. Soc., vol. 50, 1894, p. 716, pl. 34, figs. $13 a, b$.

"Test subpyriform, but somewhat compressed, tapering more acutely towards the aboral extremity; test rhomboidal in section, surface smooth, and swollen along the centre of each face. About six chambers are visible on each surface, slightly inflated, and bordered by "well marked sutures. The last chamber is pinched up towards the apex; but it embraces the whole width of the test, after the manner of Frondicularia and Lingulina. Aperture slightly elongate, with a stellate border. Length one sixty-sixth inch $(0.37 \mathrm{~mm}$.), width one one-hundred-and-thirtieth inch $(0.19 \mathrm{~mm}$.).

"This form also appears to represent a new genus or subgenus, combining two hitherto distinct generic types.

"One specimen from the pebble bed, Littleton."

We have no specimen of the present species.

The above is quoted directly from Chapman, and the figures are copied from his plate.

\section{QUADRULINA LAGENALIS (Terquem)}

Plate 1, figures $6 a, b$

Polymorphina lagenalis Terquem, Quatr. Mém. Foram. Lias, 1864, p. 301, pl. 13, figs. $39 a, b$.

Terquem's description of the species runs as follows:

P. testa laevigata, elongata, ovata, rotundata, postice obtusa, antice succisa, lateribus aequali, loculis septem alanis, quatuor induplice cruce dispositis, uno in medio quadrangulari, apertura magna, long. $0.58 \mathrm{~mm}$.

Locality: Quenleu-les-Metz, lower Lias.

This is a distinctive species having a tetraloculine arrangement of chambers and is here copied in order to show a Jurassic example of the genus.

Terquem's figures are not sufficient to show completely the tetraloculine arrangement of chambers.

Genus GUTTULINA d'Orbigny, 1826

\section{GUTTULINA PROBLEMA d'Orbigny}

Plate 2, figures 1-6; Plate 3, figures $1 a-c$

Guttulina problema d'Orbigny, Ann. Sci. Nat., vol. 7, 1826, p. 266, No. 14.Cushman and Schenck, Univ. Calif. Publ., Bull. Dept. Geol. Sci., vol. 17,1928 , p. 310 , pl. 43 , figs. $9-11$.

Polymorphina problema d'Orbigny, Modèles, 1826, No. 61.-H. B. Brady, Rep. Voy. Challenger, Zoology, vol. 9, 1884, p. 568, pl. 72, fig. 20; pl. 73, fig. 1.-Jones, Foram. Crag, pt. 3, 1896, p. 267, pl. 1, fig. 64; pl. 5, fig. 23; pl. 6, figs. $12 a$, b.-Burrows and Holland, Proc. Geol. Assoc., 
vol. 15, 1897, p. 46, pl. 2, fig. 17.-Weller, Geol. Surv. New Jersey, Paleontology, vol. 4, 1907, p. 253, pl. 3, figs. 27, 28.-Cushman, Bull. 100, U. S. Nat. Mus., vol. 4, 1921, p. 264, pl. 54, figs. 3, 4; U. S. Geol. Survey Prof. Paper 133, 1923, p. 33, pl. 5, fig. 6.-Chapman, New Zealand Geol. Survey, Pal. Bull. No. 11, 1926, p. 68, pl. 5, figs. 10-12.

Polymorphina (Guttulina) problema Andreae, Abhandl. Geol. Special-Karte Elsass-Lothringen, vol. 2, pt. 3, 1884, p. 118, pl. 9, fig. $21 a-c$.

Polymorphina problema var. Hosius, Ver. Nat. Hist. Vereins Pr. Rheinlande, vol. 50, 1893, p. 103, pl. 2, figs. $2 a-c$ (not figs. 3-5).

Guttulina communis d'Orbigny, Ann. Sci. Nat., vol. 7,1826 , p. 266, No. 15, pl. 12, figs. 1-4, Modèles No. 62.-Reuss in Geinitz, Grundr. Verstein., $1845-46$, p. 669 , pl. 24 , fig. 82.

Polymorphina communis Roemer, Neues Jahrb. f. Min., etc., 1838, p. 385, fig. 29.-H. B. Brady, Parker, and Jones, Trans. Linn. Soc., vol. 27, 1869 , p. 224, pl. 39, figs. $10 a$, b.-H. B. BraDy, Rep. Voy. Challenger, Zoology, vol. 9, 1884 , p. 568, pl. 72, fig. 19.-Fuint, U. S. Nat. Mus. Rept., 1897, p. 319, pl. 67, fig. 6 (part).-BAGG, Bull. 88, U. S. Geol. Survey, 1898, p. 60, pl. 6, fig. 2.-Fornasini, Mem. Accad. Sci. Istit., Bologna, ser. 5, vol. 8, 1900, p. 33, fig. 37.-Weller, Geol. Survey New Jersey, Paleontology, vol. 4, 1907, p. 248, pl. 3, fig. 18.-BAGG, U. S. Geol. Survey, Bull. 513, 1912, p. 68, pl. 21, figs. $7 a, b, 13-15$.-Cushman, Bull. 71, U. S. Nat. Mus., pt. 3, 1913, p. 87, pl. 37, fig. 7.

Polymorphina lactea Walker and JaCOB var. communis Williamson, Recent Foram. Great Britain, 1858, p. 72, pl. 6, figs. 153-155.

Polymorphina (Guttulina) lata EgGer, Neues Jahrb. für Min., Jahrg. 1857, p. 288, pl. 13, figs. 22-24.

Guttulina cretacea ALth, Haidinger's Nat. Abhandl., vol. 3, 1850, p. 262, pl. 13, fig. 14.-Reuss, Haidinger's Nat. Abhandl., vol. 4, 1851, p. 28, pl. 4 , fig. 10 .

Polymorphina cretacea EgGer, Abhandl. Kön. bay. Akad. Wiss. München, Cl. II, vol. 21 , pt. 1,1899 , p. 127 , pl. 17 , figs. $12,13$.

Globulina irregularis Terquem, Mém. Soc. Géol. France, sér. 3, vol. 1, 1878, p. 44 , pl. 4 (9), figs. 13,14 .

Polymorphina lactea Sidebottom, Mem. Proc. Manchester Lit. Philos. Soc., vol. 5, No. 9, 1907, p. 9, pl. 2, fig. 11.-Franke, Abhandl, geol. pal. Instit. Univ. Greifswald, vol. 6, 1925, p. 77, pl. 6, fig. 18; Danmarks Geol. Unders. 2, Raekke, No. 46, 1927, p. 34, pl. 3, fig. 13.

Globulina gibba var. glomula Fornasini, Mem. Accad. Istit. Bologna Sci., ser. 5, vol. 9, 1900-1902 (1902), p. 68, fig. 20 in text.

Test broadly fusiform, acute at the apertural end, more or less rounded at the initial end in the megalospheric form, rather rounded at the base in the microspheric form; chambers elongated, more or less inflated, arranged in a clockwise, quinqueloculine series, each succeeding chamber slightly removed from the base; sutures depressed, very distinct; wall rather thick, smooth; aperture radiate.

Length, 0.50-1.25 mm.; breadth, 0.40-1.25 mm.; thickness, 0.28$0.70 \mathrm{~mm}$.

Most authors describe Guttulina problema as a species having chambers arranged triserially or crowded together irregularly, but we have seen no specimens having triserial or irregularly arranged chambers, and all the specimens are characterized by a quinquelocu- 
line arrangement of chambers. Brady, Parker, and Jones give a figure drawn from d'Orbigny's model No. 61 (pl. 39, fig. 71a), but so far as our model shows, the figure is not well drawn and does not represent the species correctly. The trouble is that d'Orbigny's Guttulina problema, figured from the Vienna Basin, so far as his original specimen examined by Ozawa is concerned, is different from his original represented by the model. Moreover the model, judging from ours, seems not to be made well.

That is, the arrangement of chambers shown by the model appears at first to be in a very roughly clockwise quinqueloculine series, and the third chamber is added abnormally. D'Orbigny's original specimen is lost; therefore the model is the only reference having any authority. It may be supposed that d'Orbigny's original of Guttulina problema was an abnormal specimen.

We have examined some Pliocene material from Castel Arquato, which is the original locality of d'Orbigny's Guttulina problema, and obtained some specimens which are very close to d'Orbigny's model, but there is no abnormal specimen just like the model. One of our specimens is figured. The figured specimen, as well as the others. from the same locality, more or less resemble Guttulina communis figured by d'Orbigny in 1826, the differences are that Guitulina problema has one more chamber than the latter, and its later chambers are slightly more slender. Such differences are, of course, of very little importance for specific separation in this group, as they are not constant.

Brady, Parker, and Jones recognized the close relationship between Guttulina problema and Guttulina communis, but they preferred to accept the models No. 61 and No. 62 as a basis of subdivision, while later Brady proposed to unite them in the Challenger report, although he gave separate names to the figures.

Reuss, when he described Polymorphina problema var. deltoidea in $1866,{ }^{6}$ placed together Guttulina communis, Guttulina problema, and Guttulina austriaca; this conclusion might have been guided by the figures in the Vienna Basin monograph. However, d'Orbigny's Guttulina communis figured in the Vienna Basin monograph is the same as Reuss's Guttulina dilatata described in 1851, and d'Orbigny's Guttulina problema in the same paper is nothing but a specimen having one more chamber than Guttulina communis (Guttulina dilatata). Guttulina austriaca is, as discussed later, quite different from the other two. The above discussion was confirmed by the study of both the holotypes and paratypes.

At first, we endeavored to separate Guttulina problema and Guttulina communis, but a study of the large accumulation of both fossil and

${ }^{6}$ Deutsch. d. Matem.-Natur. Classed. k. Akad. Wissens, vol. 25, p. 154. 
recent specimens led us to unite them. The difference between them is only in the shape of chamber, more precisely the degree of elongation.

Guttulina cretacea Alth differs from the present species in its inflated chambers, and is close to Globulina gibba var. glomula Fornasini from the Pliocene of Siena which, according to Fornasini, is an intermediate between Guttulina problema and Globulina gibba. However, both Guttulina cretacea and Globulina gibba var. glomula, though they have slightly depressed sutures, retain the quinqueloculine arrangement of chambers, and they resemble Guttulina problema more than Globulina gibba. Therefore, they are included in Guttulina problema.

We have specimens referred to this species from the following localities: Recent.-Albatross D4807, off Japan; D5141, vicinity of Jolo, P. I.; D5469, east coast of Luzon, P. I.; D2756, off Brazil; shore sand, Rimini, Italy; off southwest Ireland; Dry Tortugas, Fla.

Pleistocene.-United States, Lomita quarry, Palos Verdes Hills, Calif.

Pliocene.--United States, Timms Point, San Pedro, Calif.

Miocene.-Germany, Dingden, Westphalia, Ortenburg; Hungary, Kostej, Banat; Tortonian sand, Varpolata; Austria, Bujtur, Siebenburgen; France, Burdigalien superieur, Pont Gourguet, Saucats; Burdigalien moyen, Le Coquillat, Leognan; Burdigalien inferieur, St. Paul de Dax; Moulin de l'Eglise, Saucats; Australia, Filter quarry, near Batesford, Victoria; Bird Rock Cliffs, Torquay, Victoria; Danger Point, Torquay, Victoria; lower beds, Muddy Creek; United States, Oak Grove sand, 100 yards below Oak Grove Bridge, Yellow River, Fla.; Chipola marl, Chipola River, Calhoun County, Fla.

Oligocene.-Germany, Upper Oligocene, Ahnatal, near Cassel; Doberg, near Bünde; middle Oligocene, Septarienthon, Hermsdorf, near Berlin; Flonheim, Mainz Basin; Wiesloch, near Heidelberg; Oeding, Westphalia; Düsseldorf; Hildesheimer Wald, near Dickholzen, Hanover; Lobsann, Alsace; United States, lower Oligocene, Red Bluff clay, Red Bluff, Wayne County, Miss.

Eocene.-United States, Jacksonian, Tarkiln Creek, one-half mile above Neuches River, Tex.; Cooper marl, South Carolina; Claibornian of Alabama, Mississippi, and Louisiana; Vincentown, N. J.; Cipero section, Trinidad, British West Indies; Midwayan, Texas; France, Lutetien, Parnes (Les Bôves); Vaudancourt; Orbitolites bed and Middle bed, Grignon; Campbon Liveau de Rilly, Damery; Belgium, Wansin.

Cretaceous.-Holland, upper Senonian, Maastricht; United States, Ripley formation, Owl Creek, Miss.; Upper Cretaceous, Texas. 


\section{GUTTULINA BULLOIDES (Reuss)}

\section{Plate 1, figures 7,8}

Globulina bulloides Reuss, Sitz. Akad. Wiss. Wien, vol. 44, pt. 1, 1861 (1862), p. 318 , pl. 3 , fig. 4 .

Guitulina bulloides Terquem (?), Mém. Soc. Géol. France, sér. 3, vol. 1, 1878 , p. 47 , pl. 4 (9), figs. $27 a, b$.

Globulina deformis D'Orbigny, Ann. Sei. Nat., vol. 7, 1826, p. 267, No. 27.

Polymorphina (Globulina) deformis Fornasini, Riv. Ital. Pal., vol. 8, 1902, p. 3 , pl. 1, fig. 9 .

Test diagonally oval, nearly as wide as long, rounded at both ends; chambers inflated, rounded, slightly embracing, arranged in an almost clockwise, quinqueloculine series; sutures much depressed, distinct; wall smooth, thick; aperture radiate.

Length $0.40-1.50 \mathrm{~mm}$; breadth $0.40-1.40 \mathrm{~mm}$; thickness $0.25-$ $0.75 \mathrm{~mm}$.

The present species is characterized by rounded chambers, the last of which is much removed from the base. We have several specimens of the present species from the Miocene in the environs of Bordeaux which are just the same as Fornasini's figure. In its essential features, our specimens resemble Globulina bulloides described by Reuss from the Cretaceous of Maastricht. Our series of specimens shows that the species is a variable one.

Guttulina bulloides Terquem, having rounded chambers separated by deep sutures, seems perhaps to belong to the present species, but we have no topotype specimens for comparison.

Specimens in our collection which may be referred to this species with more or less question are from the following localities:

Recent.-Shore sand, Coffins Beach, Annisquam, Mass.; Albatross D2415, 440 fathoms, and D2416, 276 fathoms, both off the Carolina coast.

Pliocene.-Crag, Sutton, England.

Miocene.-France, Helvetian, Salles, Moulin du Minoy; Burdigalien, Moulin de l'Eglise, Saucats; St. Paul de Dax; Hungary, Lapugy; Trinidad, Cipero section.

\section{GUTTULINA BARTSCHI Cushman and Ozawa, new species}

Plate 1, figures $10 a-c$

Test ovate, with broadly rounded end (young) to oblong (adult), initial end obtuse and rounded, apertural end acuminate; chambers inflated, slightly longer than wide, slightly embracing, arranged in a nearly quinqueloculine series; sutures depressed, distinct; wall smooth, thick, translucent; aperture radiate.

Length $0.50-0.70 \mathrm{~mm}$; breadth $0.35-0.60 \mathrm{~mm}$.; thickness $0.30-$ $0.45 \mathrm{~mm}$. 
Holotype-(U. S. Nat. Mus. No. 12612.) From Albatross D5178, in 78 fathoms off Romblon, P. I.

It also occurs in the Philippines from the following stations: D5143, 19 fathoms and D5144, 19 fathoms, both off Jolo Jolo; D5152, 34 fathoms, Tawi Tawi group; D5268, 170 fathoms, Verde Island Passage; D5319, 340 fathoms, China Sea off Formosa. It also occurs at D4883, 53 fathoms, off Japan. We have specimens from off the Poor Knights Islands, New Zealand, in 60 fathoms, and from Van Diemans Inlet, Gulf of Carpenteria, Queensland, Australia, 10 fathoms. There are specimens in the collection from the lower Pliocene of Beaumaris, near Melbourne, Victoria, Australia.

The species is named after Dr. Paul Bartsch, of the United States National Museum, who collected much of the material in the Albatross cruise in the Philippines.

In general outline, Guttulina bartschi is similar to Guttulina regina distributed in the Indo-Australian region; but $G$. bartschi has a smooth surface.

\section{GUTTULINA ORIENTALIS Cushman and Ozawa}

Plate 3 , figures 2,3

Guttulina orientalis Cushman and Ozawa, Contr. Cushman Lab. Foram. Res., vol. 4, 1928, p. 15, pl. 2, fig. 1; Jap. Journ. Geol. Geogr., vol. 6, 1929, p. 66, pl. 13, fig. 1; pl. 14, figs. 1, 2.

Test ovate to broadly fusiform, greatest breadth usually slightly below the middle, base broadly rounded; chambers inflated, clavate, arranged in a clockwise, quinqueloculine series, each succeeding chamber farther removed from the base; sutures only slightly depressed, distinct; wall smooth, polished, thick; aperture radiate.

Length of adult specimens, $1.00-1.42 \mathrm{~mm}$.; breadth, $0.65-0.83 \mathrm{~mm}$.; thickness, $0.55-0.69 \mathrm{~mm}$.

Guttulina orientalis most closely resembles Guttulina problema, from which it is distinguished by its more inflated chambers arranged much closer in a quinqueloculine series, and each succeeding chamber is removed much farther from the base. From Guttulina austriaca it is easily separated by its less depressed sutures, more rounded base, and inflated chambers.

Distribution.-The species occurs at numerous localities about Japan. The type locality is from the upper Pliocene of Sawane, Island of Sado, Japan. It occurs also in the upper Pliocene of Natsukawa, and there are numerous Recent specimens from off Kobama. In the Albatross dredgings, it occurs at D4826, 114 fathoms, D4843, 100 fathoms, both off Japan.

In addition, there is in the collection a single specimen of similar form in Doctor Bagg's material from Timms Point, Calif. It may be noted also that we have a very few specimens from the Miocene of 
Bordeaux that in size and general arrangement of chambers are very similar.

\section{GUTTULINA IRREGULARIS (d'Orbigny)}

Plate 3, figures 4, 5; Plate 7, figures 1, 2

Globulina irregularis D'Orbigny, Foram. Foss. Bass. Tert. Vienne, 1846, p. 226, pl. 13, figs. 9, 10.-Cushman and Thomas, Journ. Pal., vol. 3, 1929 , p. 177 , pl. 23 , figs. $2 a-c$.

Guttulina dilatata Reuss, Denkschr. K. Akad. Wiss. Wien, vol. 1, 1850, p. 378 , pl. 48 , fig. 11 .

Guttulina problema D'Orbigny (not d'Orbigny 1826), Foram. Foss. Bass.

Tert. Vienne, 1846, p. 224, pl. 12, figs. 26-28.-Reuss, in Geinitz,

Grundr. Verstein., 1845-46, p. 669, pl. 24, fig. 83.

Globulina guttula Reuss, Zeitschr. deutsch. geol. Ges., vol. 3, 1851, p. 82, pl. 6 , fig. 46 .

Gultulina semiplana Reuss, Zeitschr. deutsch. geol. Ges., vol. 3, 1851, p. 82, pl. 6 , fig. 48 .

Guttulina centrata Terquem, Mém. Soc. Géol. France, sér. 3, vol. 1, 1878, p. 46 , pl. 4 (9), figs. $25 a-26$.

Polymorphina byramensis Cushman, U. S. Geol. Survey Prof. Paper 129-E, 1922, p. 94, pl. 17, figs. $2 a$, $b$; Idem, Prof. Paper 133, 1923, p. 31, pl. 5, figs. $1-5$.

Guttulina byramensis Cushman and Schenck, Univ. Calif. Publ., Bull. Dept. Geol. Sci., vol. 17, 1928, p. 309, pl. 43, figs. 6-8.

Test oval to subdeltoidal, equilaterally triangular with rounded sides and angles, excepting the acute apertural end; chambers more or less angular, elongated, arranged in a clockwise, quinqueloculine series, each succeeding chamber excepting the last one or two chambers in full grown specimens coming down to the base; sutures depressed, distinct; wall smooth, but in full-grown specimens often having the last small chamber with spines or covered with fistulose tubes; aperture radiate.

Length, 0.45-1.40 mm.; breadth, 0.30-1.20 mm.; thickness, $0.20-0.75 \mathrm{~mm}$.

Guttulina irregularis is closely related to Guttulina problema in its quinqueloculine arrangement of chambers and depressed sutures, and naturally it was recorded by most authors under the names of Guttulina problema or Guttulina communis. D'Orbigny himself described and figured the present species in the Vienna monograph as three different species, Guttulina communis, Guttulina problema, and Globulina irregularis. Ozawa examined both holotype and paratype specimens of the above three species as well as a great deal of material collected from the Vienna Basin Tertiary, and is convinced that the three species as used in the 1846 paper are really nothing more than one and the same organism in different phases of growth. "Guttulina communis" is the adult and most common form of d'Orbigny. Guttulina problema is an older stage with one more chamber, and Globulina irregularis represented by a somewhat 
abnormal specimen having an irregular growth of chambers. There is some doubt about the holotype specimen of Globulina irregularis preserved in the Museum of Paris, because the specimen is also labelled "Guttulina communis, var.," and it is equilaterally triangular in outline instead of globular as figured by d'Orbigny. It would be considered that d'Orbigny's figures for Globulina irregularis are much modified from the specimen now in the museum as in the case of Guttulina problema and Guttulina communis in the same paper. There is no specimen like the Globulina irregularis figured by d'Orbigny, either in the paratype specimens or among our topotypes. Therefore, in this paper we take the specimen in the Museum at Paris as the holotype and give the somewhat abnormal specimen having the very inadequate name of Globulina irregularis the priority over several specific names given the specimens considered to be identical with the present species. It is to be noted here that Polymorphina irregularis d'Orbigny in the Cuban monograph is a different species from Globulina irregularis in the Vienna monograph in which Globulina is used as a genus.

Guttulina dilatata Reuss recorded from the Vienna Basin Miocene in 1850 is different from Polymorphina dilatata described by the same author in the following year 1851, and is a very good representation of the present species. Reuss' Globulina guttula and Guttulina semiplana from Hermsdorf are the same, the former being a young and the latter an adult. They are very close to Guttulina irregularis and are placed in the synonymy.

Guitulina centrata Terquem, having a rounded outline and much involute chambers is approaching Sigmoidella. This is shown in young stages of Guttulina irregularis. It appears not to be well drawn and is provisionally included in the present species.

Polymorphina byramensis Cushman, one of the most common species in the American older Tertiary, in its general features is closely related to the present species.

Distribution.-This is one of the most common species of the Polymorphinidae. It ranges from the Cretaceous to the Recent, and geographically is also widely distributed. We have specimens from the following localities referable to this species:

Recent.-Italy, shore sand, Lido, Venice; Australia, shore sand, Torquay, on Bass Strait, Victoria; New Zealand, off North Cape, 75 fathoms; off Oamaru, 50 fathoms; off the Big King, 98 fathoms; off Poor Knights Islands, 60 fathoms; east coast United States, Albatross D2415, off the Carolina coast, 440 fathoms; D2262, south of New England, 250 fathoms.

Pliocene.-Island of Cyprus, Lanarka; Italy, Coroncina, near Siena; Castel Arquato; Ponticello, near Bologna. 
Miocene.-United States, Choctawhatchee marl, near Red Bay, Fla.; Chipola marl, Chipola River, Calhoun County, Fla.; Australia, Janjukian, Filter quarries, Batesford, Victoria; Bird Rock Cliffs, Torquay, Victoria; bore, Hopevale Station, Sutherlands Creek, near Geelong, Victoria; Balcombian, Kackeraboite Creek, Victoria; Austria, Amphistegina-marl and Leithakalk, Grunes Kreuz, Nussdorf, near Vienna; Tortonian, Loos, Vienna Basin; Hungary, Tortonian, Varpolata; Lapugy; Kostej; France, Helvetian, Pontlevoy; Salles, Moulin de Minoy; Burdigalien moyen, Le Coquillat, Leognan; Burdigalien recifal, St. Paul de Dax, Landes, Burdigalien inferieur, Moulin de l'Eglise, Saucats (Gironde).

Oligocene.-Germany, upper Oligocene, Ahnatal, near Cassel; middle Oligocene, Flonheim, Mainz Basin; Hermsdorf near Berlin; Pietzpuhl; Söllingen; Duisberg; Oeding; Düsseldorf, Dickholzen; Lobsann; lower Oligocene, Lattdorf; Australia, Clifton Bank, near Hamilton, Victoria; United States, Byram marl, Byram and Vicksburg, Miss.; Mint Spring Marl, Mint Spring Bayou, Vicksburg, Miss., and many other localities recorded; Mexico, numerous localities in Tampico embayment region.

Eocene.-United States, Jacksonian, 11/2 miles south of Shubuta, Miss.; 1 mile south of Yazoo City, Miss.; west bank of Chipola River, east of Marianna, Jackson County, Fla., and many other stations.; Claibornian, Cook Mountain formation, Moseleys Ferry, Caldwell County, Tex.; Sabine County, Tex.; Alabama; Louisiana; Vincentown, N. J.; Midwayan, Naheola formation, Naheola Landing, Tombigbee River, Ala.; Midway, Tex. Mexico, many stations in Alazan clays, Guayabal formation, Guayahal. Trinidad, Hermitage quarry, Dumfries Road; Cipero section; Vistabella quarry. Hungary, Neustift, Ofen. Austria, Bartonian, Bruderndorf, near Stockerau. France, Lutetien, Parnes (Les Bôves); Damery; Chaussy; Grignon; Courtagnon. Italy, Bartonian, Val di Lonte. England, Bracklesham beds, White Cliff Bay, Isle of Wight. Belgium, basal Eocene, Wansin.

GUTTULINA IRREGULARIS d'Orbigny var. NIPPONENSIS Cushman and Ozawa, new variety

Plate 7 , figures $3 a-c$

Variety differing from the typical in having the later chambers not much removed from the base and having a tendency to embrace the earlier ones; that is, it is approaching Sigmoidella. It is noteworthy that the direction of the quinqueloculine arrangement of chambers is either clockwise or contraclockwise as in Sigmoidella pacifica.

Length $0.70-0.75 \mathrm{~mm}$.; breadth $0.45-0.55 \mathrm{~mm}$.; thickness $0.33-0.37$ $\mathrm{mm}$.

Holotype of variety (Cushman Coll. No. 11140).-From upper Pliocene, Okuwa, Province of Kaga, Japan. Paratypes in Geological Institute, Imperial University of Tokyo, Japan. 
The specimens having a contraclockwise arrangement of chambers, more or less resemble Guttulina lactea, but the sutures are more depressed and the outline is more triangular instead of the oval or ovate form of Guttulina lactea.

Distribution.-Found only in the Japanese Pliocene deposits and as a Recent form.

GUTTULINA FRANKEI Cushman and Ozawa, new species

Plate 4, figures $1 a-c$

Polymorphina lactea var. cuspidata Franke, Abhandl. Mus. Nat. Magdeburg, 1925, p. 177, pl. 6, fig. $46 b$.

Test nearly quadrangular, almost symmetrical, apertural and initial ends very acute, forming opposite diagonal angles, other two angles rounded; chambers clavate, not embracing, earlier ones small, later ones much enlarged, arranged in a clockwise, quinqueloculine series; sutures depressed, distinct; wall smooth, rather thick; aperture radiate.

Length $0.60-0.82 \mathrm{~mm}$; breadth $0.35-0.55 \mathrm{~mm}$.; thickness $0.25-$ $0.35 \mathrm{~mm}$.

Holotype (Cushman Coll. No. 10588).-From the middle Oligocene of Söllingen, Germany. We also have specimens from the Oligocene of Oeding, Westphalia, Germany. Very similar specimens occur in the upper Eocene, Cooper marl of South Carolina.

Guttulina frankei more or less resembles Guttulina irregularis in its general characters, but the former has the more acute base, often with a spine at its initial end. It differs from the microspheric form of Guttulina irregularis which has invariably a rounded base and is usually more or less equilaterally triangular.

Franke's Polymorphina lactea var. cuspidata reported from the lower Oligocene of Magdeburg is characterized by a cuspidate initial end and is very similar to the present species. However, the name cuspidata has already been used by Brady, and we have attached Doctor Franke's name to this species.

\section{GUTTULINA TRIGONULA (Reuss)}

Plate 4, figures $2 a-c$

Polymorphina trigonula Reuss, Die Verstein. böhm. Kreide, 1845, p. 40, pl. 13, fig. 84.-H. B. Brady, Parker, and Jones, Trans. Linn. Soc., vol. 27,1870 , p. 232 , pl. 40 , figs. $16 a, b$.

Polymorphina damaecornis Reuss, Die Verstein. böhm. Kreide, 1845, p. 40, pl. 13, fig. 85.

Polymorphina (Guttulina) damaecornis Jones and Chapman, Journ. Linn. Soc. Zool., vol. 25, 1896, p. 508, fig. 2 (in text).

Test spheroidal, truncate at the base, obtuse at the apertural end; chambers rounded, inflated, arranged in a clockwise, quinqueloculine series, each succeeding chamber extending back to the base but not 
covering the earlier chambers at the base; sutures depressed, distinct; wall smooth, the apertural end often covered with fistulose tubes; aperture produced, radiate.

Length $0.35-0.70 \mathrm{~mm}$; breadth $0.35-0.65 \mathrm{~mm}$.; thickness $0.25-$ $0.48 \mathrm{~mm}$.

Guttulina trigonula is allied to Guttulina problema and like it has the chambers arranged in a quinqueloculine series, but differs from it in the truncate, somewhat three-sided base. The test itself is much rounded and much wider than long. Guttulina damaecornis mentioned by Reuss in the same paper as the present species is undoubtedly a fistulose specimen of Guttulina trigonula.

Polymorphina glomerata Roemer ${ }^{7}$ characterized by a spheroidal test composed of inflated and rounded chambers, appears to be very close to Guttulina trigonula, but the figures lack details. The fact also that we have no specimens in our collection that seem identical has left us in doubt whether it be a valid species or a synonym of the present one.

Distribution.-Reuss recorded the present species from the Cretaceous of Luschnitz in Bohemia. Our figured specimen was obtained from the lower Gault clay at Barnwell Pit, in Cambridge, England. The other localities of our specimens from the Cretaceous are: Maastricht, Holland; Stemmerberg, Westphalia; Hinter-Fessen near Pirna, Germany; Velasco shale, Hacienda El Limon, west of Panuco, Mexico.

\section{GUTTULINA AUSTRIACA d'Orbigny}

Plate 4, figures $3-5$

Guttulina austriaca D'Orbigny, Foram. Foss. Bass. Tert. Vienne, 1846, p. 223, pl. 12, figs. 23-25.-Terquem, Mém. Soc. Géol. France, sér. 3, vol. 2, 1882 , p. 133 , pl. 13 (21), fig. 36.

Polymorphina oblonga D'Orbigny, Foram. Foss. Bass. Tert. Vienne, 1846, p. 232, pl. 12, figs. 29-31.-Terquem, Mém. Soc. Géol. France, sér. 3, vol. 2 , 1882 , p. 145 , pl. 15 (23), fig. 9.-H. B. Brady, Rep. Voy. Challenger, Zoology, vol. 9, 1884, p. 569, pl. 73, fig. 4 (not figs. 2 and 3).Chaster, First Rept. Southport Soc. Nat. Sci., 1890-91 (1892), p. 64, pl. 1, fig. 13.-BAGG, U. S. Geol. Survey, Bull. 513, 1912, p. 73, pl. 20, figs. 10-12.-Cushman, Bull. 71, U. S. Nat. Mus., pt. 3, 1913, p. 88, pl. 37, fig. 6; Idem, Bull. 100, vol. 4, 1921, p. 268, pl. 52, fig. 3 .

Polymorphina guttata Reuss, Sitz. Akad. Wiss. Wien, vol. 62, pt. 1, 1870, p. 487.-v. Schlicht, Foram. Septar. Pietzpuhl, 1870, pl. 30, figs. 25-32.

Test fusiform to oblong, more or less rounded at the base, rather acute at the apertural end, often botryoidal, greatest breadth usually above the middle; chambers oval to clavate, slightly embracing, arranged in a clockwise, quinqueloculine series, each succeeding chamber removed much farther from the base; sutures depressed and very distinct; wall smooth, translucent; aperture produced, radiate. 
Length $0.60-1.15 \mathrm{~mm}$; breadth $0.40-0.55 \mathrm{~mm}$; thickness $0.35-$ $0.50 \mathrm{~mm}$.

Original specimen in Paris, paratypes in Vienna.

Guttulina austriaca has been often confused and mistaken by various authors. It is generally considered to be identical with Guttulina problema and $G$. communis. We do not deny its close relationship to Guttulina problema, because it has the same arrangement of clavate chambers, although in the present species each succeeding chamber is removed from the proloculum, which is always very distinct in a young specimen. In the plate are illustrated three phases of the growth of Guttulina austriaca from specimens collected from the original locality. The youngest is a specimen coinciding in every respect with d'Orbigny's Guitulina austriaca, and the largest adult specimen is nothing but the species described by d'Orbigny under the name Polymorphina oblonga (not of Roemer nor of Williamson).

Polymorphina guttula Reuss, a name given to the figures (pl. 30, figs. 25-30) of Schlicht, having a botryoidal test, is closely related to the present species.

Distribution.-We have specimens of this species from the following localities:

Recent.-Italy, Shore sand, Rimini; Pacific, off Watson's Bay, Port Jackson, New South Wales, Australia; Kobama, Japan; Albatross D5318, 340 fathoms, China Sea, vicinity of Formosa.

Pleisiocene.-Canada, Glacial clays, McGill College Grounds, Montreal.

Pliocene.-Italy, Castel Arquato; Coroncina, near Siena; Belgium, Crag noir, Antwerp; Japan, Okuwa, Province of Kaga; Natsukawa, Province of Echigo.

Miocene.-Hungary, Kostej; Lapugy; Varpolata; Austria, Tortonian, Grunes Kreuz, Nussdorf; Perchtoldsdorf; Baden, near Vienna.

Oligocene.-Upper Oligocene, Germany, Ahnatal near Cassel. Middle Oligocene, Flonheim, Mainz Basin. Lower Oligocene, Lattdorf.

Eocene.-France, Lutetien, Parnes (Les Bôves); Lutetien moyen, Grignon. Lower Eocene, Belgium, Wansin.

GUTTULINA YABEI Cushman and Ozawa

Plate 4, figures 6,7

Guttulina yabei Cushman and Ozawa, Jap. Journ. Geol. Geogr., vol. 6, 1929, p. 68 , pl. 13 , fig. 2 ; pl. 14, fig. 6 .

Polymorphina oblonga H. B. Brady (not d'Orbigny), Rep. Voy. Challenger, Zoology, vol. 9, 1884, pl. 73, figs. 2, 3.

Test elongate fusiform, rounded, greatest breadth above the middle, base rounded; chambers numerous, inflated, one and one-half times as long as broad, arranged in a close sigmoid series, each chamber added with its base at about the middle of the previous chamber 
adjacent to it; sutures very distinct, depressed; wall smooth, polished, thick, translucent; aperture radiate, terminal.

Length $1.50 \mathrm{~mm}$.; breadth $0.75 \mathrm{~mm}$.

Holotype.-(Geological Institute, Imperial University of Tokyo, Japan.) From the upper Pliocene, Sawane, Island of Sado.

This species is evidently the same as that figured by Brady. ${ }^{8}$ Brady's specimens are from the Australian region, and are not the same as d'Orbigny's Polymorphina (Guitulina) oblonga from the Miocene of the Vienna Basin, which is a much smaller species as well as differing in other characters. Topotypes of d'Orbigny's species have been compared with the Japanese specimens.

In the Albatross collections, the species occurs at Stations D4807, 44 fathoms and D4826, 114 fathoms off Japan.

\section{GUTTULINA YABEI Cushman and Ozawa var. OVALE Cushman and Ozawa}

\section{Plate 40 , figure 6}

Guttulina yabei Cushman and Ozawa var. ovale Cushman and Ozawa, Jap. Journ. Geol. and Geog., vol. 6, 1929, p. 68, pl. 13, fig. 3; pl. 14, fig. 7.

Variety differing from the typical form in having the sutures less depressed, and the chambers less inflated, due to the greater overlapping of the chambers. The figured specimen measured $2.5 \mathrm{~mm}$. in length, and $1.1 \mathrm{~mm}$. in breadth.

The types are from the upper Pliocene of Sawane, Island of Sado, Japan.

\section{GUTTULINA SPICAEFORMIS (Roemer)}

Plate 5, figures 1, 2

Polymorphina spicaeformis Roemer, Neues Jahrb. für Min., 1838, p. 386, pl. 3 , fig. 31 .

Polymorphina austriaca D'Orbigny var. io Cushman and Applin, Bull. Amer. Assoc. Petr. Geol., vol. 10, 1926, p. 174, pl. 9, figs. 6, 7.

Guttulina plancii D’Orbigny, Voy. Amér. Mérid., vol. 5, pt. 5, "Foraminifères," 1839 , p. 60 , pl. 1 , fig. 5 .

Polymorphina uviformis Reuss, Zeitschr. deutsch. geol. Ges., vol. 7, 1855, p. 289, pl. 11, fig. 5 .

Test fusiform, initial end rounded, apertural end acute, margin slightly lobulate; chambers clavate, but little embracing, arranged in a contraclockwise, quinqueloculine series, each succeeding chamber removed from the base; sutures depressed, distinct; wall smooth; aperture radiate.

Length $0.35-0.75 \mathrm{~mm}$; breadth $0.20-0.35 \mathrm{~mm}$; thickness $0.12-$ $0.25 \mathrm{~mm}$.

In general form, Guttulina spicaeformis most resembles Guttulina austriaca d'Orbigny from the Vienna Basin in that it has rather short, clavate chambers combined so as to form a typical fusiform test. It 
however possesses a contraclockwise quinqueloculine arrangement of chambers as distinctly shown in the figure given by Roemer.

Polymorphina uviformis Reuss may represent a Cretaceous specimen of the present species, and we have no reason to separate it from Guttulina spicaeformis.

Guttulina plancii d'Orbigny described from the Bay of San-Blas, Patagonia, and Polymorphina austriaca var. io Cushman and Applin are also placed under the synonymy of the present species.

Distribution.-Geologically and geographically Guttulina spicaeformis is widely distributed. We have species from the following localities:

Recent.-Atlantic, West Indies, Dry Tortugas, 11 and 18 fathoms; San Juan Harbor, P. R., 6 fathoms; coast of Belgium; Gaspé Bay, 10-15 fathoms; Australia, Hardwick Bay, east side of Spencer Gulf; New Zealand, off the Big King, 98 fathoms; off the Snares; Oamaru.

Miocene.-Australia, Filter Quarry, Batesford, Victoria.

Oligocene.-Germany, Düsseldorf; Söllingen; Oeding, Westphalia.

Eocene.-United States, Cooper marl, west side of Biggin Creek, Berkeley County, S. C.; Ocala limestone, west bank of Chipola River, at Wagon Bridge, east of Marianna, Jackson County, Fla.; east bank of Sepulga River, north of Brooklyn, Conecuh County, Ala.; road from Perdue Hill to Claiborne, Monroe County, Ala.; Jacksonian, Jackson, Miss.; bluff on Garlands Creek, 5 miles northeast of Shubuta, Wayne County, Miss.; bluff on Chickasawhay River at Hayes Chapel, Wayne County, Miss.; Stovall Creek, east of Diboll, Tex.; three-fourths mile below Robinson's Ferry, Sabine River, Sabine, Tex.; Wilmington, N. C., Claibornian; roadside going down to river, Claiborne, Ala.; Midwayan, Tex. England, Bracklesham beds X, XIII, XVIII, Isle of Wight. Thanetian, Pegwell Bay. France, Lutetien, Parnes (Les Bôves), Damery.

\section{GUTTULINA SPICAEFORMIS (Roemer), var. AUSTRALIS (d'Orbigny)}

Plate 5, figures $3 a-c$

Globulina australis d’Orbigny, Voy. Amér. Mérid., 1839, vol. 5, pt. 5, “Foraminifères," p. 60 , pl. 1, figs. 1-4.

Polymorphina australis H. B. Brady, Parker, and Jones, Trans. Linn. Soc., vol. 27,1869 , p. 239 , pl. 41 , figs. $27 a, b$.

Polymorphina regina Cushman, U. S. Geol. Survey Prof. Paper 129, 1921, p. 94, pl. 18, fig. 4; Carnegie Instit. Washington, Publ. No. 311, 1922, p. 33, pl. 4, figs. 5, 6; U. S. Geol. Survey Prof. Paper 133, 1923, p. 33.

Variety differing from the typical in its ornamentation, consisting of fine, longitudinal costae, generally well developed on the lower half of the test. There are intermediate specimens in which the markings become obscure.

Length $0.45-0.63 \mathrm{~mm}$; breadth $0.25-0.32 \mathrm{~mm}$; thickness $0.18-$ $0.25 \mathrm{~mm}$. 
Distribution.-This variety has occurred in considerable numbers at various stations off the Dry Tortugas, off Florida, and off Cuba. Specimens of very similar character and seemingly identical occur in the Eocene, Bracklesham beds XVII and XVIII, Isle of Wight, England, and in the lower Oligocene, Byram marl of Byram, Miss.

GUTTULINA HANTKENI Cushman and Ozawa, new species

Plate 5, figures 4-6

Polymorphina acuta HAntKen, Mitth. Jahrb. K. Ungar. geol. Anstalt, vol. 4, 1875 (1881), p. 60, pl. 8, fig. 4 (acuminata on explanation of plate).

Test oval, botryoidal, more or less rounded at the base, acute at the aperture, greatest breadth above the middle; chambers ovate, embracing but little, arranged in a contraclockwise, quinqueloculine series, each succeeding chamber removed farther from the base sutures much depressed, very distinct; wall smooth, thick; aperture acutely produced, radiate.

Length $0.60-1.20 \mathrm{~mm}$; breadth $0.35-0.75 \mathrm{~mm}$; thickness 0.30 $0.60 \mathrm{~mm}$.

Holoiype.-(Cushman Coll. No. 11194.) Eocene, Kleinzellen, bei Ofen, Hungary.

Guttulina hantkeni has a typical botryoidal test consisting of ovate chambers, while other botryoidal species such as Guttulina austriaca and Guttulina spicaeformis have invariably more slender tests consisting of clavate chambers.

The Cretaceous Polymorphina uviformis Reuss, which is included in Guitulina spicaeformis (Roemer) in this paper, seems to represent an intermediate form between Guttulina hantkeni and Guttulina spicaeformis. Both Hantken's names, Polymorphina acuta, and Polymorphina acuminata, given to the present species, are preoccupied; therefore a new specific name is proposed, named for Doctor Hantken.

Distribution.-Guttulina hantkeni seems to be limited in its geological distribution. Our specimens were obtained from the Eocene formations of Neustift, Ofen, Hungary, the type Jocality of Hantken's specimens, also from the middle Eocene of the United States, Claibornian, of New Jersey and Louisiana. We also have specimens from the upper Senonian of Maastricht, Holland, which are very similar.

\section{GUTTULINA PULCHELLA d'Orbigny}

Plate 5, figures $7 a-c$

Guitulina pulchella D'OrBigny, in De la Sagra, Hist. Fis. Pol. Nat. Cuba, vol. 6,1840 , p. 129 , pl. 2 , figs. $4-6$.

Polymorphina pulchella H. B. Brady, PARker, and Jones, Trans. Linn. Soc., vol. 27, 1870, p. 239, pl. 41, figs. $28 a, b .-C u s h m A N$, Carnegie Instit. Washington, Publ. No. 311, 1922, p. 33, pl. 4, figs. 7, 8; Bull. 104, U. S. Nat. Mus., pt. 4,1923 , p. 157 , pl. 40 , fig. 6.

Test elongate fusiform, greatest breadth slightly below the middle; chambers elongate, clavate, scarcely overlapping, arranged in a contra.

$92709-30-3$ 
clockwise, quinqueloculine series, each succeeding chamber farther removed from the base; sutures depressed, distinct; wall thin, ornamented with fine, regular, longitudinal costae; aperture radiate.

Length $0.60-0.95 \mathrm{~mm}$; breadth $0.25-0.30 \mathrm{~mm}$; thickness $0.18-$ $0.23 \mathrm{~mm}$.

Guttulina pulchella is one of a few well-defined species among the Polymorphinidae described by d'Orbigny. Its slender, elongate chambers, marked with regular, longitudinal costae, are its characteristics and can not be confused with any of the other known species.

Distribution.-D'Orbigny recorded the present species from the shore sand of Cuba and Martinique. We have specimens from numerous stations off the Dry Tortugas, near Florida, 7-18 fathoms, and from Albatross D2420 off the eastern coast of the United States in 104 fathoms.

\section{GUTtUlina REgina (H. B. Brady, Parker, and Jones)}

Plate 6, figures 1,2

Polymorphina regina H. B. Brady, Parker, and Jones, Trans. Linn. Soc., vol. 27,1870 , p. 241 , pl. 41 , figs. $32 a, b .-$ H. B. Brady, Rep. Voy. Challenger, Zoology, vol. 9, 1884, p. 571, pl. 73, figs. 11-13.-EgGeR, Abhandl. kön. bay. Akad. Wiss., München, Cl. II, vol. 18, 1893, p. 310, pl. 9, figs. 45, 50, 51.-Chapman, Journ. Quekett Micr. Club, ser. 2, vol. 10,1907 , p. 132 , pl. 10, fig. 4.-Cushman, Bull. 71, U. S. Nat. Mus., pt. 3, 1913, p. 91, pl. 41, figs. 6, 7; Bull. 676, U. S. Geol. Survey, 1918, p. 54, pl. 11, figs. 3, 4; Prof. Paper 129-E, 1922, p. 94, pl. 18, fig. 4 ; Prof. Paper $129-$ F, 1922, p. 131, pl. 30, fig. 8.

Test broadly fusiform, obtuse and rounded at the initial end, acute at the apertural end; chambers inflated, oval, but little embracing, arranged in a quinqueloculine series, each succeeding chamber rapidly enlarged, removed slightly from the base; sutures much depressed, distinct; wall marked by equidistant, longitudinal costae; aperture radiate.

Length $0.63-0.80 \mathrm{~mm}$; breadth $0.35-0.42$; thickness $0.25-0.35 \mathrm{~mm}$.

This is a well-defined species described by H. B. Brady, Parker, and Jones, and there is but little danger of confusing it with any other species of the genus.

The surface markings are very regular and distinct, although in some specimens they are much finer.

Distribution.-The original authors reported it from soundings from Storm Bay, Tasmania. It is common off the eastern coast of Australia. We have specimens from Albatross D5152, 34 fathoms, Sulu Archipelago; D5311, 88 fathoms, China Sea, off southern Luzon, P. I.; shore sand, Torquay, on Bass Strait, Victoria, Australia; shore sand, Newcastle Bay, New South Wales; Van Dieman's Inlet, Gulf of Carpenteria, Queensland, 10 fathoms; and Wool Bay, Yorkes Peninsula, west side of St. Vincent Gulf, South Australia. 
GUtTulina REgina (H. B. Brady, Parker, and Jones) var. CRAssiCOStata Cushman and Ozawa, new variety

\section{Plate 11, figures $5 a-c$}

Variety differing from the typical in the very broad, coarse costae and in the shape of the test, which instead of having the greatest breadth decidedly below the middle has a more regularly fusiform test; the chambers not as inflated as in the typical form.

Holotype of variety. - (Cushman Coll. No. 11891.) From the lower Pliocene, Beaumaris, near Melbourne, Victoria, Australia.

This variety is very distinct from the typical form. The costae are extremely thick and heavy, even more so than shown in the figure.

\section{GUTTULINA COSTATULA Galloway and Wissler}

\section{Plate 6, figures $3 a, b$}

Polymorphina (Guttulina) costatula Galloway and Wissler, Journ. Pal., vol. 1, 1927, p. 57, pl. 9, figs. $10 a, b$.

Test short, somewhat fusiform, acute at both ends; chambers inflated, rounded, not much embracing, arranged in a contraclockwise, quinqueloculine series, each succeeding chamber removed much farther from the base; sutures depressed, distinct; wall ornamented with numerous distinct, rounded costae, of which there are five more strongly developed at the base, radiating from the acute initial end independent of the sutures and taking positions in accord with the quinqueloculine arrangement of the early chambers; aperture produced, radiate.

Length $0.40-0.60 \mathrm{~mm}$.; breadth $0.27-0.35 \mathrm{~mm}$.; thickness $0.18-0.24$ $\mathrm{mm}$.

Guttulina costatula is very close in its general outline and ornamentation to Guttulina regina (H. B. Brady, Parker, and Jones), but it has generally much smaller dimensions, and its five strong costae radiating from the initial end is an important character developed in only one other known species of Guttulina. It is an ornamented species close to a rather common species found in the same locality (Guttulina quinquecosta Cushman and Ozawa), which has a smooth wall excepting for the five strong costae developed at the basal region. It grows much larger than the present species.

Distribution.- The types were described from the Pleistocene, lower bed, of the Lomita Quarry, Palos Verdes Hills, 2 miles south of Lomita, Calif. We have specimens from the type locality, and also specimens that seem to be identical from the Miocene of Filter Quarry, Victoria, Australia. 


\section{GUTTULINA CAUDATA d'Orbigny}

Plate 6, figures 4, 5

Guttulina caudata D'Orbigny, Ann. Sci. Nat., vol. 7, 1826, p. 266, No. 16.Fornasini, Boll. Soc. Geol. Ital., vol. 19, 1900, p. 137, fig. 2 (in text).

Test unequally compressed, front view nearly an isosceles triangle, with broadly rounded base, the initial end with a spine; chambers elongate, arranged in a clockwise, quinqueloculine series, each succeeding chamber nearly reaching to the base; sutures but little depressed, distinct; wall smooth; aperture radiate.

Length $0.32-0.48 \mathrm{~mm}$; breadth $0.20-0.35 \mathrm{~mm}$.; thickness $0.08-0.15$ $\mathrm{mm}$.

This is one of the species listed by d'Orbigny in 1826 and figured much later by Fornasini. Its regular triangular outline with the spine at the initial end are important features which will distinguish Guttulina caudata. The quinqueloculine arrangement of the chambers of the species is very regular.

Distribution.-D'Orbigny listed it from the Adriatic Sea and as fossil from France and Castel Arquato. We have iossil specimens from France from the Eocene, Lutetien of Parnes (Les Bôves), Vaudancourt, and Beauves.

\section{GUTTULINA ADHAERENS (Olszewski)}

Plate 1, figures $9 a-c$; Plate 6 , figures $7 a, b$

Polymorphina adhaerens OLszewski, Sprawodz. Kom. Fizyj. Akad. Umiej. Krakowie, vol. 9, 1875, p. 119, pl. 1, fig. 11.

Test ovate, broadest below the middle, rounded at the base, acute toward the apertural end; chambers clavate, arranged in an almost quinqueloculine series, each succeeding chamber slightly removed from the base; sutures but little depressed, distinct; wall smooth; aperture radiate.

Length $0.50-1.10 \mathrm{~mm}$.; breadth $0.35-0.80 \mathrm{~mm}$.; thickness $0.22-0.50$ $\mathrm{mm}$.

The quinqueloculine arrangement of the chambers of the present species has a tendency to become triserial. Accordingly a side view often shows only three chambers of which the middle one seems to be much inflated and produced between the others. This appearance is very characteristic of the species.

Distribution.-Rather common in various Cretaceous deposits in Europe, especially in the Chalkmarl and the Gault of England. We have it also from the Cretaceous of Maastricht, Holland. 
GUTTULINA ADHAERENS (Olszewski) var. CUSPIDATA Cushman and Ozava, new variety

Plate 6, figure 6

Polymorphina species, Burrows, Sherborn, and Balley, Journ. Roy. Micer. Soc., 1890, p. 561, pl. 11, fig. 15.

Variety differing from the typical in the development of a distinct basal spine.

Length including spine $0.50-0.65 \mathrm{~mm}$; breadth $0.30-0.45 \mathrm{~mm}$; thickness $0.18-0.30 \mathrm{~mm}$.

Holotype of variety.-(Cushman Coll. No. 11209.) From the Cretaceous, chalk marl of Folkestone, England.

This variety is abundant in our collections from the chalk marl and Cambridge Greensand of the Saxon Cement Works, at Cambridge, England. Burrows, Sherborn, and Bailey's specimen was from the Red Chalk in England. We also have it from the lower Cenomanian, Tecklenburg Wald, Westphalia, Germany.

\section{GUTTULINA PRAELONGA (Egger)}

Plate 6, figures $8 a-c$

Polymorphina praelonga EgGer, Neues Jahrb. für Min., Jahrg., 1857, p. 287, pl. 13, figs. 25-27.-Terquem, Mém. Soc. Géol. France, sér. 3, vol. 1, 1878 , p. 39 , pl. 3 (8), figs. 20-21b.-Jones and CHAPMAN, Journ. Limn. Soc. Zool., vol. 25,1896 , p. 511, fig. 20 (in text).-BAGG, Maryland Geol. Surv. (Eocene), 1901, p. 249, pl. 63, fig. 14.

Polymorphina (Globulina) angusta EgGer, Neues Jahrb. für Min., Jahrg. 1857, p. 290, pl. 13, figs. 13-15.-Andrate, Abhandl. Geol. SpecialKarte Elsass-Lothringen, vol. 2, pt. 3, 1884, p. 210, pl. 9, fig. 17,EgGer, Abhandl. kön. bay. Akad. Wiss., München, Cl. II, vol. 18, 1893, p. 308, pl. 9, figs. 5-7.

Guttulina austriaca D'Orbigny var. angusta Terquem, Essai Class. Anim. Dunkerque, 1881, p. 130, pl. 17, fig. $5 a, b$.

Polymorphina dispar Terquem, Essai Class. Anim. Dunkerque, 1881, p. 130, pl. 17 , fig. $4 a, b$.

Test elongate, more or less cylindrical, broadest below the middle, tapering toward the aperture, rounded at the initial end; chambers elongate, clavate, arranged in a quinqueloculine series, not much embracing; sutures depressed, distinct; wall smooth; apertural end often with fistulose tubes; aperture radiate.

Length $0.45-0.95 \mathrm{~mm}$; ; breadth $0.22-0.38 \mathrm{~mm}$.; thickness $0.10-0.16$ $\mathrm{mm}$.

We have examined a paratype specimen of Egger's Polymorphina praelonga and are convinced that it is identical with Polymorphina angusta described by him in the same paper. Egger's Polymorphina praelonga is a full-grown specimen having one or two nore chambers than Polymorphina angusta. The figures of Polymorphina praelonga Egger show the chambers arranged in a biserial series, but they are undoubtedly not well drawn.

Terquem figured and described Polymorphina praelonga in 1878, which is the same as Polymorphina angusta Egger. 
Terquem's Guttulina austriaca var. angusta and Polymorphina dispar are also placed in the synonymy of the present species. The former has a slightly shorter test.

The latter appears to have one or two more chambers than the usual specimens of Polymorphina praelonga.

Polymorphina cylindrica Prochazka having a cylindrical test consisting of rather short chambers, is not much different from Polymorphina angusta or Polymorphina austriaca var. angusia Terquem.

Distribution.-Egger's types are from the Miocene. We have a paratype of Egger's from Ortenburg. The species occurs also in the Miocene of France at Dax and Le Coquillat, Leognan, France, as well as in the upper Oligocene (Stampien ) of Jeurs, France. All these localities have a fauna very closely related to that described by Egger. Somewhat similar specimens occur in widely different localities such as the upper end of Buzzards Bay, Mass., Kobama, Japan; Wool Bay, Yorkes Peninsula, west side of St. Vincent Gulf, Australia. Somewhat similar specimens occur in the Pliocene of Fiji and in the Eocene of the Isle of Wight, England, Grignon and Parnes (Les Bôves), France, and in the Jackson of the United States. It is probable that these do not all represent a single species, but the specimens have a very similar arrangement and shape of the chambers. Some are clockwise and others contraclockwise in their arrangement, but the distinction does not seem to be constant.

\section{GUTTULINA GUTTIFORMIS (Terquem)}

Plate 6, figures $9 a-c$

Polymorphina guttiformis Terquem, Mém. Soc. Géol. France, sér. 3, vol. 1, 1878, p. 42 , pl. 9 (14), fig. $24 a, b$.

Test slender, in front view an isosceles triangle, broadest at the base, tapering toward the apertural end; chambers cylindrical, arranged in a quinqueloculine series, but little embracing, all extending back nearly to the base; sutures depressed, distinct; wall smooth; aperture radiate.

Length $0.65-0.90 \mathrm{~mm}$.; breadth $0.25-0.35 \mathrm{~mm}$.; thickness $0.16-0.24$ $\mathrm{mm}$.

This is one of the well marked species of Guttulina. Its test is elongated, but it is quite different from other elongate Guttulinas characterized by a botryoidal test, in having the chambers all extending down to the base. The nearest ally of the present species is Guttulina praelonga in which the chambers are much more inflated.

Distribution.-We have specimens from the following localities:

Miocene.-Burdigalien, France, St. Paul de Dax; Moulin de l'Eglise, Saucats.

Oligocene.-Germany, Ahnatal, near Cassel; Hildesheimer Wald, Dickholzen, Hanover. 
Plate 7, figures 4, 5

Test ovate, greatest breadth near the middle, broadly rounded at the base, more or less acute at the apertural end; chambers inflated, twice as long as wide, not much embracing, arranged in a clockwise, quinqueloculine series, each succeeding chamber removed regularly from the base giving a rounded appearance at the base; sutures depressed, distinct; wall smooth, thick; aperture radiate.

Length $0.90-1.80 \mathrm{~mm}$.; breadth $0.80-1.50 \mathrm{~mm}$; thickness $0.50-$ $1.00 \mathrm{~mm}$.

Holotype-(Cushman Coll. No. 11226.) From Tertiary, lower marl, Cipero section, Trinidad.

The present species is generally very large, attaining to nearly 2 millimeters in length. In its general appearance, it has an intermediate character between Guttulina problema and Guttulina hantkeni. From the former it differs in its rather broad base and much obliquely added chambers, and from the latter in its more or less elongate chambers, of which each succeeding one is not much removed from the base.

Distribution.-Several specimens were found in the Tertiary material from Trinidad, collected by P. W. Jarvis. They are from the Eocene of the Cipero section and also from the "Uvigerina bed" and the "upper marl" of the same part of the island. We have a single specimen from Albatross D5318 off the Philippines which is very close to this species from Trinidad.

\section{GUTTULINA LEHNERI Cushman and Ozawa, new species}

Plate 8, figures 1,2

Test ovate to clavate, broadest in the lower half, broadly rounded at the base, tapering to the apertural end; chambers elongated, embracing, arranged in a regular, quinqueloculine series; sutures not depressed, not very distinct; wall smooth, thick, often with fistulose tubes at the apertural portion; aperture radiate.

Length $0.65-1.35 \mathrm{~mm}$; breadth $0.38-0.55 \mathrm{~mm}$.; thickness $0.25-$ $0.36 \mathrm{~mm}$.

Holotype.-(Cushman Coll. No. 10436.) From Tertiary, lower marl, south end of Hospital Hill, San Fernando, British West Indies.

Guttulina lehneri resembles Guttulina problema in general character, but it has elongated but not inflated chambers and nondepressed sutures, therefore its surface is quite even, and at a glance it can be easily separated from other Guttulinas. It is approaching Globulina, but the chambers are arranged in a regular quinqueloculine series.

Distribution.-Rather common in the Tertiary of Trinidad. It occurs in the "lower marl" of the Cipero section and also in the "Sagrina beds" of Oropouche Lagoon, Trinidad. 
Plate 8 , figures 3,4

Test elongate, the base broadly rounded, uniformly tapering toward the apertural end; chambers elongated, especially in the later ones, arranged in a quinqueloculine series, each succeeding chamber slightly removed from the base; sutures but little depressed, distinct; wall smooth, rather thick; aperture radiate.

Length $0.80-1.35 \mathrm{~mm}$.; breadth $0.35-0.65 \mathrm{~mm}$; thickness 0.20 $0.45 \mathrm{~mm}$.

Holotype.-(Cat. No. 20950, U.S. N. M.) From Albatross D4807, in 44 fathoms off Cape Tsiuka, Japan.

The elongated test composed of elongated chambers is very characteristic of the present species. The specific name is dedicated to Prof. N. Yamazaki, Geographical Institute, Imperial University of Tokyo.

Distribution.-The species occurs living off Japan, and is fossil in the upper Pliocene.

Recent.-Albatross D4807, off Cape Tsiuka, Japan, 44 fathoms. Tuscarora 11 , in 437 fathoms.

Pliocene.-Natsukawa, Province of Echigo, Japan.

\section{GUTTULINA KISHINOUYI Cushman and Ozawa, new species}

\section{Plate 8, figures 5, 6}

Test elongated, the greatest breadth in the lower half, broadly rounded at the base but pointed at the initial end, gradually tapering toward the aperture; chambers much elongated, roundly triangular in cross section, embracing, arranged in a clockwise quinqueloculine series, each succeeding chamber but little removed from the base; sutures slightly depressed, distinct; wall smooth, polished; aperture radiate.

Length $0.52-0.95 \mathrm{~mm}$.; breadth $0.30-0.40 \mathrm{~mm}$.; thickness $0.18-0.25$ $\mathrm{mm}$.

Holotype.-(Cushman Coll. No. 11234.) From the upper Pliocene, Natsukawa, Province of Echigo, Japan. (Paratypes, Geological Insíitute, Imperial University of Tokyo, Japan.)

The present species resembles Guttulina yamazakii found in the same region in its elongated test composed of long chambers. However, it has more slender chambers which are invariably but little removed from the base, and the chambers are embracing and much more strongly involute than those of $G$. yamazakii. The species is named for the late Professor Kishinouyi, of Japan, whom we both claimed as a friend.

Distribution.-Recent specimens are from Albatross dredgings, China Sea, off Formosa, D5315, in 148 fathoms, and D5585 Sibuko Bay, Borneo in 476 fathoms. It also occurred at Tuscarora 11, lat. $33^{\circ} 46^{\prime} \mathrm{N}$., long. $140^{\circ} 21^{\prime} \mathrm{E}$. in 437 fathoms. 
Plate 9, figures 1,2

Test large, ovate, broadly rounded at the base; chambers elongated, especially the later ones, numerous, not much embracing, arranged in a quinqueloculine series, each succeeding chamber removed farther from the base in the early stage, but little in the later stage; sutures depressed, but not very distinct; wall thick, smooth; aperture radiate.

Length $1.15-1.55 \mathrm{~mm}$; breadth $0.70-0.80 \mathrm{~mm}$; thickness $0.50-$ $0.60 \mathrm{~mm}$.

Holotype-(Cat. No. 20951, U.S.N.M.) From Albatross D2416, lat. $31^{\circ} 26^{\prime} \mathrm{N}$., long. $79^{\circ} 07^{\prime} \mathrm{W}$., in 276 fathoms off the southeastern coast of the United States.

The present species is one of the largest among our collection of Polymorphinidae. Its early stage is just the same as Guitulina problema, but it has more numerous chambers, and the later chambers are much elongated and often added in a spiral series. It may be interesting to compare the present species with Sigmomorpha crassa, which is very large and in its early stage resembles Gutiulina problema, but later the chambers are more or less shortened and added in a sigmoid series instead of a quinqueloculine series as in the present species. It is named for Prof. J. W. Bailey, one of the early American workers on the foraminifera.

Distribution.-Besides the type locality, we have material very similar from Albatross D5151, 24 fathoms, Tawi Tawi Group, Philippines.

\section{GUTTULINA ROEMERI (Reuss)}

Plate 9, figures $3 a-c$

Globulina roemeri Reuss, Sitz. Akad. Wiss. Wien, vol. 18, 1855 (1856), p. 245 , pl. 6 , fig. 63 .

Guttulina deformata Reuss, Sitz. Akad. Wiss. Wien, vol. 18, 1855 (1856), p. 245 , pl. 6 , fig. 64 .

Polymorphina uvula EgGer, Neues Jahrb. für Min., Jahrg. 1857, p. 285, pl. 10, figs. 26-29.

Guttulina dubia Awerinzew, Mem. Acad. Imp. Sci. St. Petersbourg, vol. 29, No. 3, 1911, p. 19, pi., figs. $4 a-d$.

Polymorphina deflexa Grzyвowski, Mikrofauna Karpackiego piaskowka Z. Pod. Dukli Krakowie, 1894, p. 16, pl. 3, figs. 1, 2.

Polymorphina sororia Chapman, Bull. Geol. Surv., W. Australia, No. 72, 1917, p. 34, pl. 10, fig. 92.

Test ovoid to oblong, almost roundly triangular in the end view, the greatest breadth above the middle, rounded at the base; chambers inflated, oval, embracing, arranged in a nearly triserial series; sutures slightly depressed, distinct; wall thick, smooth; aperture radiate.

Length $0.70-1.80 \mathrm{~mm}$.; breadth $0.50-1.00 \mathrm{~mm}$.; thickness $0.38-0.75$ $\mathrm{mm}$. 
In its general aspect excepting for the depressed sutures, Guttulina roemeri bears much resemblance to Globulina rotundata. It is not difficult to separate them if one examines closely their earlier stages. By taking off one chamber from such specimens as Globulina obtusa or G. globosa figured by Bornemann, they are very close to Globulina gibba. On the other hand, Guttulina roemeri is undoubtedly derived from such a form as Guttulina problema by losing the quinqueloculine arrangement of chambers and the chambers becoming more inflated and embracing. The sutures, therefore, are always more or less depressed.

Globulina roemeri figured by Reuss appears to us not to represent the typical form of the species. Although its sutures are depressed, it resembles Globulina rotundata in its general aspect.

Guttulina deformata described by Reuss in the same paper as the above species, with its test almost triangular in the end view is close to Grzybowski's Polymorphina deflexa from the Miocene of Europe.

Such a form as the latter is of the most common occurrence in various deposits. In the synonymy of the present species, Egger's Polymorphina uvula may be placed with some doubts. Egger's specimens are apparently very variable, but they have invariably triangular sections and the chambers are separated by the depressed sutures and arranged in a nearly triserial series. Awerinzew's Polymorphina dubia is close to the present species, the difference being mainly in the one extra chamber, and is undoubtedly to be placed in the synonymy of the present species.

Distribution.- Specimens referred to this species are in our collection from the following localities:

Recent.-Off Tripoli.

Pliocene.-Crag of Sutton, England.

Miocene.-Austria, Tortonian, Amphistegina marl of Grunes Kreuz, Nussdorf, Vienna. France, Burdigalien moyen, Le Coquillat, Leognan. United States, Choctawhatchee marl, Red Bay, Fla.

Oligocene.-Germany, Ahnatal, near Cassel; Doberg, near Bünde. Mexico, near Cuesta Blanca, Zacamixtle, Vera Cruz.

GUTTULINA ROEMERI (Reuss) var. GIGAS (Karrer)

Plate 9, figures $4 a-c$

Polymorphina gigas KARRer, Abhandl. k. k. geol. Reichsanst, vol. 9, 1877, p. 384 , pl. 16 b, fig. 44 .

Variety differing from the typical by the more compressed and compact test and less depressed sutures with the apertural end more tapering.

Length $0.75 \mathrm{~mm}$; breadth $0.38 \mathrm{~mm}$; thickness $0.35 \mathrm{~mm}$.

Ozawa examined the original specimen in the Museum of Natural History, Vienna, and found that the species is very close to Guttulina 
roemeri in its general aspects. We have three specimens from the original locality: Tortonian, Grunes Kreuz, Nussdorf, Vienna Basin, Austria.

\section{GUTTULINA LACTEA (Walker and Jacob)}

Plate 10, figures 1-4

Serpula tenuis ovalis laevis WALKER and JACOB, Test. Min., 1784, p. 2, pl. 1, fig. 5 .

Serpula lactea WALker and $\mathrm{J}_{\mathrm{ACOB}}$ (fide Kanmacher), Adams Essays, ed. 2, 1798 , p. 634 , pl. 14 , fig. 4.

Polymorphina lactea Williamson, Recent Foram. Gt. Britain, 1858, p. 70, pl. 6, figs. 145-152.-H. B. Brady, Proc. Somerset Arch. Nat. Hist. Soc., vol.13, 1865-66 (1867), p. 114, pl. 3, fig. 49.-H. B. BRADY, PARKER, and Jones, Trans. Linn. Soc., vol. 27, 1870, p. 213, pl. 39, figs. $1 a, b$ (not 1 c).-Terquem, Essai Class. Anim. Dunkerque, 1875, p. 37, pl. 5, fig. $12 ; 1876$, p. 79 , pl. 10, figs. 19, 20.-BAGG, U. S. Geol. Survey, Bull. 513, 1912, p. 71, pl. 21, fig. 12 (not fig. $16 a, b$ ).-Cushman, Bull. 104, U. S. Nat. Mus., pt. 4, 1923, p. 146, pl. 39, fig. 9 (not fig. 11).

Guttulina lactea Ozawa, Contr. Cushman Lab. Foram. Res., vol. 5, 1929, p. 36 , pl. 6, figs. 6-10.

Guttulina deplanata Reuss, Sitz. Akad. Wiss. Wien, vol. 18, 1855 (1856), p. 246 , pl. 6, fig. 67 .

Test ovate, rounded triangular in section, tapering but little, rounded at the base; chambers elongate, somewhat compressed, arranged in a contraclockwise, quinqueloculine series, often tending to become a sigmoid series, each succeeding chamber very slightly removed from the base; sutures depressed, distinct; wall smooth, translucent; aperture radiate.

Length $0.60-0.85 \mathrm{~mm}$; ; breadth $0.35-0.40 \mathrm{~mm}$.; thickness $0.20-0.28$ $\mathrm{mm}$.

This is the earliest figured species belonging to the family of the Polymorphinidae, obtained in the sand of the seashore near Sandwich, England. Although the figures are small and can be hardly considered as well drawn, and moreover, the description being very simple, yet they are sufficient to show that the figured specimen has a rather compressed test, the chambers of which are arranged in a contraclockwise, quinqueloculine series, and in these respects it has the same characters as one of the forms figured by Williamson in the Foraminifera of Great Britain, 1858. ${ }^{9}$ Williamson's other two figures identified as Polymorphina lactea are different from Figure 147 in their acute initial end and biserial arrangement of later chambers. They are similar to Polymorphina subcompressa d'Orbigny (=Polymorphina compressa d'Orbigny). Such a biserial Polymorphina is also described by Fleming under the name of Vermiculum lacteum as early as 1822. Williamson's figure is well drawn and was taken by Brady, Parker, and Jones as a typical specimen representing Poly- 
morphina lactea in their monograph of the Genus Polymorphina. They apparently fixed the species very well, but they placed many different species in the synonymy of Polymorphina lactea, which led later authors into confusion, and since the publication of their paper the name Polymorphina laciea has been used very often, and accordingly the species has been mistaken. Probably no other species in Foraminifera has been more misunderstood than the present one.

We have examined shallow sea foraminiferal material obtained from off England, Ireland, and Iceland and isolated many specimens which can be identified with Polymorphina lactea, which are tolerably definite in their essential characters - ventricose test with depressed sutures, the elongate chambers arranged in a contraclockwise, quinqueloculine series-but often the test tends to become compressed by losing the quinqueloculine arrangement of chambers, that is, the later chambers have a tendency to be arranged in a sigmoid series.

Guttulina deplanata, described by Reuss in 1856 from the upper Oligocene of Cassel, Germany, is a compressed variety of the present species. It is rather common in the sand of Cassel, and we have many specimens from Cassel which show the same range of variation as does Guttulina laciea in a series of Recent specimens.

Distribution.-This is one of the most common species found in the shallow sea off England, Iceland, and Ireland. In the fossil state it is not as common as in the Recent. We have the species from the following localities:

Recent.-Ten miles off Glencoe, southwest Ireland, 53 fathoms; Nymph Bank, south of Cork Harbor, Ireland, 52 $\frac{1}{2}$ fathoms; off Bantry Bay, southwest Ireland, 100 fathoms; coast of Belgium; Coast of Iceland; Labrador; bathing beach, Newport, R. I.; Dry Tortugas, Fla., 18 fathoms; Montego Bay, Jamaica; Albatross D2112, Caribbean, 15 1/2 fathoms; D2614, east coast United States, 16 fathoms; D4856, coast of Japan, 898 fathoms; D5311, Philippines.

Pliocene-Japan, Natsukawa, Province of Echigo. Italy, Castel Arquato.

Miocene.-France, Burdigalien inferieur, Moulin de l'Eglise, Saucats; Le Coquillat, Leognan.

Oligocene--Germany, Ahnatal, near Cassel; Hildesheimer Wald, Dickholzen, Hanover.

Eocene.-France, Lutetien, Parnes (Les Bôves); Lutetien moyen, Grignon. 
GUTTULINA LACTEA (Walker and Jacob) var. EARLANDI Cushman and Ozawa, new variety

Plate 10, figure 5

Polymorphina concava Jones (not Williamson), Foram. Crag, pt. 3, 1896, p. 264, pl. 5, fig. 22.-Heron-Allen and Earland, Journ. Roy. Mier. Soc., 1909, p. 431, pl. 17, fig. 6 .

Polymorphina laciea var. concava Sidebottom, Mem. Proc. Manchester Lit. Philos. Soc., vol. 51, No. 9, 1907, p. 14, pl. 3, figs. 8, 9.

Variety differing from the typical in the attached character. It holds to the short form seen in the early stages of $G$. lactea.

Distribution.-From the records the variety has been found Recent in the Mediterranean, in the Pliocene (Crag) of Sutton, England, and at Selsey, England.

GUTTULINA SCHAFFERI Cushman and Ozawa, new species

Plate 11, figures $1 a-c$

Test oval, but little compressed; chambers more or less longer than wide, arranged in a nearly quinqueloculine series, each succeeding chamber removed from the base; sutures but little depressed, not very distinct; wall ornamented by rather strong, uniformly distributed spines; aperture radiate.

Length of holotype $0.65 \mathrm{~mm}$; breadth $0.42 \mathrm{~mm}$; thickness 0.25 $\mathrm{mm}$.

Holotype.-(Cushman Coll. No. 11259.) From the Miocene, Tortonian, Amphisiegina marl of Grunes Kreuz, Nussdorf, near Vienna, Austria. (Paratypes, Geological Institute, Imperial University of Tokyo, Japan.)

The shape of the test and the arrangement of chambers of the present species are very similar to Guttulina deformata, but the chambers are more slender and the surface is uniformly ornamented by blunt spines. The specific name is given for Prof. F. X. Schaffer, Director of the Geological and Paleontological Department of the Museum of Natural History in Vienna.

Distribution.-Specimens were collected from the Amphistegina marl at Grunes Kreuz in the Vienna Basin.

\section{GUTTULINA WOODSI Cushman and Ozawa, new species}

Plate 11, figures $2 a-c$

Test fusiform, greatest breadth slightly above the middle; charnbers rather inflated, not much longer than broad, embracing, arranged in a nearly quinqueloculine series, each succeeding chamber farther removed from the base; sutures but little depressed, distinct; wall rather thin, smooth; aperture produced, radiate.

Length $0.35 \mathrm{~mm}$.; breadth $0.15 \mathrm{~mm}$; thickness $0.15 \mathrm{~mm}$.

Holotype-(Cushman Coll. No. 11260.) From the Cretaceous, lower Gault, of Barnwell Pit, Cambridge, England. 
Guttulina woodsi resembles the Cretaceous Guttulina elliptica, described from Bohemia by Reuss, in its general outline, but Reuss's species is more or less compressed and the chambers are shorter. We have some doubts about the arrangement of chambers of Reuss's species.

The specific name is given for Doctor Woods of the Sedgwick Museum of Cambridge, England.

GUTTULINA QUINQUECOSTA Cushman and Ozawa

Plate 11, figures $3 a-c$

Guttulina quinquecosta Cushman and Ozawa, MS. in Cushman and Valentine, Contrib. Dept. Geol., Stanford Univ., vol. 1, 1930, p. 19, pl. 5, figs. $6 a-c$.

Test oblong, greatest breadth above the middle, regularly tapering toward the base which ends in a spine; chambers inflated, slightly longer than broad, not much embracing, arranged in a quinqueloculine series, each succeeding chamber removed farther from the base; sutures depressed, generally distinct, especially those of the later chambers; wall thick, smooth, ornamented at its basal portion with five more or less strong costae starting from the caudal spine radiating in five directions in accordance with the quinqueloculine arrangement of chambers; aperture slightly produced, radiate.

Length $0.40-0.90 \mathrm{~mm}$.; breadth $0.25-0.50 \mathrm{~mm}$.; thickness $0.20-0.40$ $\mathrm{mm}$.

Holotype-(Cushman Coll. No. 11930.) From off the Channel Islands, Calif.

In its general outline it is similar to Guttulina yabei, but it is smaller and invariably ornamented by five costae at its basal portion, as in the case of Guttulina costatula, which is an entirely ornamented and much smaller species.

Distribution.- - It seems to be limited to the California coast, where it occurs in the Pliocene and Pleistocene and also as a Recent species.

GUTTULINA PAALZOWI Cushman and Ozawa, new species

Plate 11, figures $4 a, b$

Test elongate fusiform, obtuse at the initial end, acute at the apertural end; chambers elongated but little inflated, much embracing, arranged in a quinqueloculine series, each succeeding chamber farther removed from the base; sutures but little depressed, often obscure; wall thick, smooth; aperture radiate.

Length $1.40-1.70 \mathrm{~mm}$.; breadth $0.50-0.55 \mathrm{~mm}$.; thickness $0.40-0.45$ $\mathrm{mm}$.

Holotype.-(Cushman Coll. No. 11265.) From the Upper Cretaceous of Maastricht, Holland. 
The present species is one of the most elongated and slender forms of Guttulina, and is comparable in its general outline to Pyrulina, but its chambers are arranged in a nearly quinqueloculine series. It may be considered to be an elongated, specialized form of the Cretaceous Guttulina woodsi.

The species is named for Mr. Richard Paalzow, from whom the Cretaceous material of Maastricht was obtained.

Distribution.-It is only known from the Upper Cretaceous material from Maastricht where it is rather common.

\section{GUTTULINA EMERSONI (Bagg)}

Plate 11, figure 6

Polymorphina emersoni BAGG, Bull. 88, U. S. Geol. Survey, 1898, p. 60, pl. 6, fig. 3.-Weller, Geol. Survey New Jersey, Paleontology, vol. 4, 1907, p. 249 , pl. 3 , fig. 19 .

We have no specimens comparable with the present species. Bagg's figure is not enough to give any definite idea of the species, and we can not with certainty determine to what genus it belongs. It is probably a Guttulina. If it is, it may be a young specimen having two chambers or possibly three. Bagg's description runs as follows:

"Test elongate oval, oral end acute, posterior obtusely rounded; surface of test covered completely by fine longitudinal costae; chambers two, elongated, oblique, separated by nearly straight septa slightly marked near the posterior end, depressed at the peripheral margin ; aperture rotund."

The type locality is from the Cretaceous, Monmouth formation, Freehold, N. J., recorded as very rare.

\section{GUTTULINA DA WSONI Cushman and Ozawa, new species}

Plate 12, figures 1,2

Test elongated, the greatest breadth in the upper half, uniformly tapering to the base; chambers elongated, more than three times as long as wide, not much embracing, arranged in a contraclockwise, quinqueloculine series, each succeeding chamber much farther removed from the base; sutures slightly depressed, distinct; wall rather thin, smooth; aperture radiate.

Normal forms, length $0.90-1.00 \mathrm{~mm}$; breadth $0.33-0.38 \mathrm{~mm}$.; thickness $0.30-0.35 \mathrm{~mm}$.

Holotype.-(Cushman Coll. No. 11267.) From Gaspé Bay, Province of Quebec, Canada.

We also have specimens from Hudson Bay, bay on east coast, south of Black Whale Harbor.

The present elongated species is somewhat similar to Guttulina paalzowi from the Upper Cretaceous of Maastricht in the general 
appearance, but its chambers are arranged in a contraclockwise series instead of a clockwise series, as in G. paalzowi. Moreover, its test has the greatest breadth in the upper half, while G. paalzowi is elongated fusiform.

The species is named for G. M. Dawson, one of the early workers on American foraminifera.

\section{GUTTULINA COSTULATA (Cushman)}

Plate 12, figures $3 a, b$

Polymorphina cuspidata H. B. BRAdy var. costulata Cushman, U. S. Geol. Survey Prof. Paper 129-F, 1922, p. 133, pl. 31, fig. 1; Prof. Paper 133, 1923, p. 32.

Test elongate, fusiform, a strong spine at the base; chambers elongated, inflated, not much embracing, arranged in a quinqueloculine series, each succeeding chamber removed farther from the base; sutures depressed, distinct; wall ornamented by strong, continuous, bladelike costae rather widely separated from each other; aperture radiate.

Length of holotype $0.70 \mathrm{~mm}$; breadth $0.20 \mathrm{~mm}$.

The present species is one of the most clearly marked species of Guttulina. In its general outline, it resembles Guttulina pulchella d'Orbigny from which it is easily distinguished by its strong bladelike costae entirely covering the test and a large spine at the base.

Distribution.-Cushman reported it from the lower Oligocene, Mint Spring marl, Mint Spring Bayou, Vicksburg, Miss. Specimens which seem identical occur in the lower Pliocene of Beaumaris, near Melbourne, Victoria, Australia.

As it occurs slightly earlier in the fossil series, this may be the ancestral form of Pseudopolymorphina rutila, which in its earlier stages is Guitulina-like, but later becomes definitely a Pseudopolymorphina. This is another of the interesting species connecting the lower Oligocene of the United States with the late Tertiary and Recent faunas of the Australian region.

\section{GUTTULINA SEMICOSTATA (Marsson)}

Plate 15 , figures $8 a-c$

Polymorphina semicostata Marsson, Mitth. Nat. Ver. Neu-Vorpommern. u. Rügen, Jahrg. 10, 1878, p. 150, pl. 2, figs. $19 a-c$.-Franke, Abhandl. geol. pal. Instit. Univ. Greifswald, vol. 6, 1925, p. 78, pl. 6, fig. 21.

Polymorphina var. Wright, Proc. Belfast Nat. Field Club, Appendix, 1885-86, p. 331 , pl. 27, figs. 13, 14.-Jones and Chapman, Journ. Linn. Soc. Zool., vol. 25,1896 , p. 509, fig. 3 (in text).

Test globular, broadest above the middle, more or less obtuse at the initial end; chambers rounded, much inflated, but little embracing, arranged in a quinqueloculine series, each succeeding chamber 
removed farther from the base; sutures much depressed, distinct; wall partly ornamented by longitudinal costae independent of the sutures; aperture radiate.

Polymorphina semicostata was first described by Marsson from the uppermost Cretaceous of Rügen. His figures are apparently well drawn, but seem to us not to give fully the details of the species, especially as the arrangement of chambers is not drawn in sufficient detail. Franke quite recently figured Marsson's specimen. His figure shows a nearly quinqueloculine arrangement of chambers characteristic of Guttulina. Wright figures similar specimens from the Cretaceous of Keady Hill, County Derry, Ireland. We have some material from the Cretaceous of Rügen, but could not find any specimen like the present one, and accordingly Marsson's figures are reproduced in the present paper.

Distribution.-Only known from the Upper Cretaceous (upper Senonian) of Rügen; very rare.

\section{GUTTULINA SADOENSIS (Cushman and Ozawa)}

Plate 37 , figures 1,2

Sigmomorpha sadoensis Cushman and Ozawa, Contr. Cushman Lab. Foram. Res., vol. 4, 1928, p. 17, pl. 2, fig. 11; Jap. Journ. Geol. Geogr., vol. 6, 1929 , p. 73 , pl. 13 , figs. $9-11$; pl. 16 , figs. $2-4$.

Test more or less rhomboid, greatest breadth usually below the middle, generally triangular in end view; chambers numerous, elongate, two to three times as long as broad, varying considerably in the amount of overlapping, some of the specimens with the chambers almost extending down to the base, others with the chambers considerably above the base and the last-formed chamber in the adult often not reaching back more than halfway to the base of the test; chambers arranged in a quinqueloculine series, often becoming sigmoidal; sutures depressed, distinct; wall thick but translucent, smooth; aperture radiate.

Length of holotype $0.83 \mathrm{~mm}$.; breadth $0.50 \mathrm{~mm}$.; thickness 0.36 $\mathrm{mm}$.

The present species has rather slender, clavate chambers arranged in a quinqueloculine series, which in later stages often tends to become sigmoidal. We took the present species as the genotype of Sigmomorpha, but we think it better to include it in Guttulina. It is an intermediate form between Gutiulina and Sigmomorphina.

Distribution.- It is only known from the Pliocene of Japan, at Sawané, Island of Sado in the Sea of Japan, where it is very abundant. $92709-30-4$ 
Plate 37 , figures $3-5$

Sigmoidella (Sigmoidina) pacifica Cushman and Ozawa, Contr. Cushman Lab. Foram. Res., vol. 4, 1928, p. 19, pl. 2, fig. 13; Jap. Journ. Geol. Geogr., vol. 6, 1929, p. 77, pl. 16, figs. 12, 13.

Polymorphina elegantissima Chapman (not H. B. Brady, Parker, and Jones), New Zealand Geol. Surv., Pal. Bull. No. 11, 1926, p. 67, pl. 13, fig. 10.

Test ovate, the greatest breadth below the middle, acuminate toward the aperture; chambers elongated, more or less inflated, arranged in either clockwise or contraclockwise, quinqueloculine series, earlier chambers invisible from the exterior, each succeeding chamber involves the earlier one; suture depressed, distinct; wall smooth, rather thick; aperture radiate.

Measurements of the holotype specimen as follows: Length 0.76 $\mathrm{mm}$.; breadth $0.53 \mathrm{~mm}$.; thickness $0.31 \mathrm{~mm}$.

Holotype.-(Cat. No. 20313, U.S.N.M.) From Albatross D5318, China Sea near Formosa, 340 fathoms.

Distribution.-We also have specimens from the following:

Recent.-Albatross D5315, China Sea near Formosa, 148 fathoms; from off Kobama, Sea of Japan; from off Terao Miura, Japan; off Poor Knight's Islands, New Zealand, 60 fathoms; off the Snares, New Zealand.

Miocene.--Chuthulin, Batesford, Victoria, Australia.

\section{GUTTUlina (SIGMOIDiNA) SEGUENZANA (H. B. Brady)}

Plate 37 , figures 8,9

Polymorphina seguenzana H. B. BRADy, Rep. Voy. Challenger, Zoology, vol. 9,1884 , p. 567 , pl. 72 , figs. $16,17$.

Test elongate, fusiform, compressed on three sides; broadest somewhat below the center, tapering gradually toward the apertural end and somewhat more rapidly toward the opposite extremity, which finishes in a sharp point; segments few in number, only three visible externally, long, narrow, erect; surface smooth, sutures marked by fine lines without external depressions.

Length $1.6 \mathrm{~mm}$.

The trifacial compression of the test, its acuminate initial end, and the erect position of the segments are sufficient to distinguish the species from its near allies.

This is an unusual species among the Polymorphinidae. It appears to have a triserial arrangement of chambers like Triloculina, but both ends are acute. The above description is from Brady.

Distribution.-Very rare off the Ki Islands, southwest of New Guinea, 129 fathoms; Port Jackson, New South Wales, 2-10 fathoms. 
GUTTULINA (SIGMOIDINA) SILVESTRII Cushman and Ozawa, new species

Plate 37 , figures 6,7

Test almost circular in outline, much inflated in the central part, periphery more or less angular; chambers elongated, arranged in either clockwise or contraclockwise, quinqueloculine series, involute, extra chamber short, inflated, not extending down to the base; sutures very little depressed, distinct; wall smooth, rather thick; aperture radiate.

Length $0.60-1.25 \mathrm{~mm}$; breadth $0.60-1.05 \mathrm{~mm}$; thickness $0.40-$ $0.65 \mathrm{~mm}$.

Holotype.-(Cushman Coll. No. 9863.) From the Miocene (Janjukian), Filter quarry, Batesford, near Victoria, Australia.

It differs from Sigmoidina pacifica in its circular test, more angulate peripheries and very slightly depressed sutures. It may be specially noted here that when the present species has an extra chamber the chamber is added in the same series as the arrangement of the earlier ones, although it is much shorter and does not extend down to the base. (See pl. 37, fig. 7a.) From this fact it is easily understood that the species is not a young stage of Sigmoidella elegantissima.

Guttulina disciformis, reported by Terquem from the Pliocene of the Isle of Rhodes, is very similar to the present species and may represent either a young stage or the megalospheric form of the species, but it has a rounded periphery, and it may be possible that the specimen is the young of some other species, such as Sigmoidella elegantissima, which we found in the Miocene of Pontlevoy, France. Therefore we do not like to place these specimens under such an ambiguous species as $G$. disciformis.

The species is named for Prof. A. Silvestri of Milan.

Distribution.-Recent from Australia, New Zealand and the Philippines; fossil in the Miocene of Australia. We have specimens from the following localities:

Recent.-Australia, Wool Bay, Yorkes Peninsula, west side of St. Vincent Gulf, South Australia; Hardwick Bay, east side of Spencer Gulf; New Zealand, Oamaru, 50 fathoms; off the Big King, 98 fathoms. Miocene.-Australia, Janjukian, Filter quarries, Batesford, Victoria.

\section{Genus PYRULiNA d'Orbigny, 1826}

PYRULINA GUTTA d'Orbigny

Plate 13, figures $1 a-c$

Pyrulina gutta D'Orbigny, Ann. Sei. Nat., vol. 7, 1826, p. 267, No. 28, model 30.-Ozawa, Contr. Cushman Lab. Foram. Res., vol. 5, 1929, p. 39 , pl. 6 , figs. 4,5 .

Polymorphina gutta H. B. Brady, PARker, and Jones (not d'Orbigny), Trans. Linn. Soc., vol. 27, 1870, p. 218, pl. 39, figs. $3 a, b .-$ SherborN and Chapman, Journ. Roy. Mier. Soc., ser. 2, vol. 6, 1886, p. 755, pl. 16 , fig. $6[?]$. 
Polymorphina clavata Roemer, Neues Jahrb.f. Min., etc., 1838, p. 386, pl. 3, fig. 38.

Polymorphina amygdaloides Cushman (not Reuss), U. S. Geol. Survey Prof. Paper 133, 1923, p. 32, pl. 4, fig. 9.

Test clavate, rounded at the base, tapering toward the apertural end, margin entire; chambers rounded, embracing, arranged at first in an almost triserial series, later tending to become biserial; sutures not depressed, distinct; wall smooth; aperture radiate, pointed.

Length $0.50-0.60 \mathrm{~mm}$; breadth $0.18-0.25 \mathrm{~mm}$; thickness $0.18-$ $0.25 \mathrm{~mm}$.

The original specimen (in paleontological department, Museum of Natural History, Jardin des Plantes, Paris) is lost.

D'Orbigny's figures represent the species fairly well, although his basal view showing the arrangement of chambers is not well drawn as far as the figure of the side view is concerned. D'Orbigny's specimen was obtained from the Pliocene at Castel-Arquato. We have examined material from the same locality, but we could not obtain any specimen resembling his species. The specimen figured here was found in the Eocene material from Wansin in Belgium, and the specimen is very much like d'Orbigny's model in every respect. Our specimen presents an arrangement of chambers not strictly triserial, at first somewhat triserial, but later tending to become biserial. As d'Orbigny's original specimen is lost and his figure of the basal view apparently is not well drawn, the figure showing the side view is the only means of knowing how the chambers of d'Orbigny's specimen are arranged. Judging from his figure, at least the later chambers of his species appear to be arranged in an almost biserial series, which seems to be the usual arrangement in a group of elongate, cylindrical Polymorphinidae.

D'Orbigny compared his species with Soldani's Polymorphium pyriformium figured in the Testaceographia. Soldani's specimen resembles Pyrulina gutta in its shape, but judging from the figure it seems to have fewer chambers, and it may be considered to a be a young stage of Pyrulina gutta, but it is characterized by a peculiar sigmoid suture, in which point it is quite distinct, and therefore it is advisable not to place it in the synonymy of $P$. gutta.

On the other hand, Polymorphina (Globulina) clavata figured by Roemer from the German middle Oligocene, considered from his figure, very closely resembles Pyrulina gutta.

We have additional specimens from the Eocene of France, Lutetien of Grignon, Chaussy and Courtagnon; also from the Eocene, Bracklesham beds XVII and XVIII, White Cliff Bay, Isle of Wight, England. 
PYRULINA LABIATA (Schwager)

Plate 12, figures $4 a, b$

Polymorphina labiata Schwager, Novara-Exped., Geol. Theil, vol. 2, 1866, p. 246 , pl. 7 , fig. 90 .

Test elongated, acute at both ends; chambers elongated, overlapping, arranged in a nearly triserial series from the beginning to the end, growth rapid; sutures not depressed, not distinct; wall smooth, rather thin; aperture radiate.

Length, $0.75-0.80 \mathrm{~mm}$.; breadth, $0.30-0.33 \mathrm{~mm}$; thickness, $0.30-0.33 \mathrm{~mm}$.

Pyrulina labiata in its general feature resembles $P$. cylindroides, but its chambers are arranged in a triserial series even in the later stages, and the chambers are slightly shorter than those of the latter species. Schwager's figure of the species does not clearly show the arrangement of chambers, especially that of the early stage.

Distribution.-Schwager recorded the present species from the Pliocene, upper clay of Kar Nicobar. We have specimens from the Pliocene of Fiji.

\section{PYRULINA VICKSBURGENSIS (Cushman)}

Plate 13, figures $2 a-c$

Polymorphina vicksburgensis Cushman, U. S. Geol. Survey, Prof. Paper 129-F, 1922, p. 133, pl. 31, fig. 2; Prof. Paper 133, 1923, p. 33.

Test elongate, fusiform, broadest near the initial end, which is subcircular in transverse section, the later portion becoming compressed and narrower, initial end bluntly pointed, or with a short spine; chambers becoming shorter toward the apertural end in the adult and arranged in an almost biserial series; surface smooth or with very slight longitudinal costae; sutures not depressed but often standing out as clearer areas in side view; aperture radiate.

Length, $1.50 \mathrm{~mm}$. or less; breadth, $0.40 \mathrm{~mm}$.

Type specimen from Station 6451, Mint Spring Bayou, Vicksburg, Miss. This species occurs also at Station 6448, Glass Bayou, Vicksburg, Miss.

This seems to be different from the other described species of this genus, and may be distinguished especially by the cuspidate initial end and the peculiar change in shape from the rounded early portion to the narrow, compressed last-formed portion.

\section{PYRULINA EXTENSA (Cushman)}

Plate 12, figures $5 a-c$

Polymorphina longicollis H. B. Brady; Rep. Voy. Challenger, Zoology, vol. 9, 1884 , p. 572, pl. 73, figs. 18, 19.-EGGER, Abhandl. kön. bay. Akad. Wiss., München, Cl. II, vol. 18, 1893, p. 310, pl. 9, fig. 21.-Cushman, Bull. 71, U. S. Nat. Mus., pt. 3, 1913, p. 90, pl. 41, figs. 1-3.

Polymorphina extensa Cushman, Bull. 71, U. S. Nat. Mus., pt. 3, 1913, p. 90 , pl. 41, figs. 1-3; Bull. 104, pt. 4, 1923, p. 156, pl. 41, figs. 7, 8. 
Test elongate, fusiform, margin almost entire, initial end more or less pointed, apertural end produced into an elongate, cylindrical neck; chambers not numerous, inflated; sutures fairly distinct, but not depressed, except in the case of the last-formed one; wall more or less hispid, the last chamber especially more inflated and spinose and often covered with fistulose tubes; aperture a long neck, not radiate.

Length, $0.50-0.85 \mathrm{~mm}$; breadth, $0.22-0.28 \mathrm{~mm}$.; thickness, $0.22-0.28 \mathrm{~mm}$.

The present species is very unique in its long produced neck and lip, which are similar to those of Uvigerina, but the other characters are undoubtedly those of Pyrulina.

Distribution.-It is known as a Recent species and seems to be mostly limited to the deep sea. Brady figures an excellent specimen from the South Atlantic from Challenger 388, in 1,990 fathoms (3,640 meters), and records it also from the South Pacific. We have Recent specimens from the Atlantic off the eastern coast of the United States from Albatross D2035 in 1,362 fathoms, D2105 in 1,395 fathoms, and D2562 in 1,434 fathoms. There are also specimens with hispid exterior from the Tertiary of Trinidad, from South of Hospital Hill, San Fernando, collected by P. W. Jarvis which are very close to Recent specimens. We have also a single smooth specimen with an elongated neck similar to this species from the middle Oligocene of Hermsdorf near Berlin, which should be noted in connection with this species. More specimens are needed to definitely place it. It also occurs in the Pliocene of Fiji, a series of sediments deposited in fairly deep water.

\section{PYRULINA FUSIFORMIS (Roemer)}

Plate 13, figures 3-8

Polymorphina fusiformis Roemer, Neues Jahrb. für Min., etc., 1838, p. 386, pl. 3, fig. 37.-H. B. Brady, PARKer, and Jones, Trans. Linn. Soc., vol. 27, 1870, p. 219, pl. 39, figs. $5 b, c$; and Woodcut e.-Jones and Chapman, Journ. Linn. Soc. Zool., vol. 25, 1896, p. 511, fig. 15 (in text).

Gütulina cylindrica Bornemann, Zeitschr. deutsch. geol. Gesell., vol. 7, 1855, p. 347, pl. 18, figs. 4-6.

Polymorphina cylindroides Reuss (not Roemer), Sitz. Akad. Wiss. Wien, vol. $18,1855(1856)$, p. 249 , pl. 8 , fig. 78 .

Guttulina ovalis Bornemann, Zeitschr. deutsch. geol. Gesell., vol. 7, 1855, p. 345 , pl. 17, fig. 7.-Cushman, Bull. Soc. Sci. Seine-et-Oise, ser. 2, vol. 9 , 1928, p. 50, pl. 1, fig. $7 a, b$.

Polymorphina subteres Reuss, Sitz. Akad. Wiss. Wien, vol. 42, 1860, p. 361 , pl. 2, fig. 14 .

Pyrulina obtusa Reuss, Sitz. Akad. Wiss. Wien, vol. 46, pt. 1, 1862 (1863), p. 79 , pl. 9 , fig. 9 .

Polymorphina lanceolata Reuss, Sitz. Akad. Wiss. Wien, vol. 48, pt. 1, 1863, p. 58, pl. 7, figs. $75,79-84$ (not figs. $76-78$ ) ; vol. 62 , pt. 1,1870 , p. 487 .v. Schlicht, Foram. Septar. Pietzpuhl, 1870, only pl. 31, figs. 1, 2, 5-8, 
17-20, 25-27.-Hosius (not Reuss), Ver. Nat. Hist. Vereins Pr. Rheinlande, vol. 50, 1893, p. 107, pl. 2, fig. 7.-Jones and Chapman, Journ. Linn. Soc. Zool., vol. 25, 1896, p. 510, figs. 11, 12 (in text).-PAALzow, Ber. Offenb. Ver. Nat., 1912, p. 68, pl. 1, figs. 11, 12.-Cushman, Bull. 71, U. S. Nat. Mus., pt. 3, 1913, p. 86, pl. 40, fig. 2.-Franke, Danmarks Geol. Unders. 2, Raekke, No. 46, 1927, p. 36, pl. 3, fig. 12.

Polymorphina (Guttulina) lanceolata Andreat, Abhandl. Geol. SpecialKarte Elsass-Lothringen, vol. 2, pt. 3, 1884, pp. 118, 141, pl. 9, figs. $18-20$.

Polymorphina tenera Karrer, Sitz. Akad. Wiss. Wien, vol. 58, abt. 1, 1868, p. 174 , pl. 4 , fig. 9 .

Polymorphina sororia var. cuspidata Chapman (not H. B. Brady), Journ. Roy. Micr. Soc., 1896, p. 13, pl. 2, fig. 13.

Polymorphina ampla Cushman (not Karrer), Bull. Amer. Assoc. Petr. Geol., vol. 10,1926 , p. 603 , pl. 20 , fig, 6 .

Polymorphina angusta H. B. BRAdy (not Egger), Rep. Voy. Challenger, Zoology, vol. 9 , 1884, p. 563, pl. 71, figs. $17-19$; pl. 72 , fig. 4.-СНАРмAN and PARR, Journ. Linn. Soc. Zool., vol. 36, 1926, p. 392, pl. 21, fig. 75 .

Test fusiform to cylindrical, acute at both ends, often with a spine at the initial end, almost circular in end view; chambers rather short, not much embracing, arranged at first in a nearly triserial series, later becoming biserial; sutures not depressed, generally distinct; wall smooth; aperture radiate.

Length $0.55-1.25 \mathrm{~mm}$; breadth $0.20-0.50 \mathrm{~mm}$.; thickness $0.20-$ $0.50 \mathrm{~mm}$.

There are many specific names given to this cylindrical member of the genus, having the chambers rather short and not much embracing. Of these names, that of Roemer's appears to be the earliest. Roemer's figure, as nearly as can be made out and considered from our study of many topotypes obtained from Cassel, seems to represent a rather young stage, having but few chambers. Pyrulina fusiformis is quite distinct from Pyrulina cylindroides which has long fusiform chambers.

Among the figures of Guttulina cylindrica given by Bornemann, Figures 4 and 5 are fair representatives of the present species, and Figure 6 is considered to be an adult specimen. Guttulina ovalis Bornemann is closely related to Globulina minima but it has more chambers regularly arranged, and it seems better to place it in the synonymy of the present species.

Reuss's Polymorphina lanceolata, figured in 1863 (excepting figures 76,77 ), and Polymorphina subteres coincide in their every feature with Pyrulina fusiformis.

Polymorphina tenera Karrer having a rounded initial end, and Polymorphina sororia var. cuspidata H. B. Brady, with an initial spine, are considered to be included in the range of variation of the present species. 
Distribution.-Rather common in various Tertiary deposits in Europe and widely distributed geographically in the Recent oceans. Our specimens are obtained from the following localities:

Recent.-Atlantic, Albatross D2035, 1,362 fathoms; D2038, 2,033 fathoms; D2042, 1,555 fathoms; D2109, 142 fathoms; D2174, 1,594 fathoms; D2228, 1,582 fathoms; D2677, 478 fathoms; D2678, 731 fathoms, all off the eastern coast of the United States; D2160, 167 fathoms off Cuba. Pacific, Nero Stations 170, 1,990 fathoms; $1287,1,606$ fathoms; $1,299,1,817$ fathoms; $1300,1,529$ fathoms; 1312, 1,552 fathoms; 1316, 1,649 fathoms; 1324, 1,915 fathoms. There are specimens also from off Alaska.

Pleistocene.-Leda Clay, Province of Quebec, Canada.

Miocene.-Hungary, Kostej, Banat. Austria, Baden, Vienna Basin.

Oligocene.-Germany, Ahnatal, near Cassel; Hermsdorf, near Berlin; Pietzpuhl; Hildesheimer Wald, Dickholzen, Hannover; Lobsann; Doberg, near Bünde.

\section{PYRULINA CYLINDROIDES (Roemer)}

Plate 14, figures $1-5$

Polymorphina cylindroides Roemer, Neues Jahrb. f. Min., etc., 1838, p. 385, pl. 3, fig. 26.-H. B. Brady, Parker, and Jones, Trans. Linn. Soc., vol. 27,1870 , p. 221 , pl. 39 , figs. $6 a, b, c$.

Polymorphina fusiformis Cushman (not Roemer), Bull. Amer. Assoc. Petr. Geol., vol. 10, 1926, p. 604, pl. 20, fig. 14.

Test elongate, fusiform to cylindrical, acuminate toward both extremities, almost circular in cross section; chambers elongate, not much embracing, arranged in a nearly triserial series, tending to become biserial, each succeeding chamber farther removed from the base; sutures but little depressed; wall smooth; aperture radiate.

Length $0.50-1.10 \mathrm{~mm}$.; breadth $0.18-0.32 \mathrm{~mm}$.; thickness $0.15-$ $0.30 \mathrm{~mm}$.

As Roemer's figures of the present species are rather obscure, owing to their small size and poor execution, we have endeavored to get a specimen which is most nearly like his figures among our abundant specimens from the German Oligocene of various localities. The specimen figured in the plate is considered by us as typical of Roemer's Polymorphina cylindroides, and the above description is written in accordance with our specimen. Pyrulina cylindroides of our diagnosis was generally identified with Polymorphina fusiformis, from which it is easily separable by its elongate chambers.

Cretaceous Pyrulina porrecta Reuss is almost impossible to distinguish from the present species, and as far as the material examined is concerned there is no distinction between them. From Cretaceous Pyrulina acuminata it is easily separated by its elongate chambers but little embracing. 
Distribution.-The present species is widely distributed in various Cretaceous deposits both in Europe and America. In the Tertiary and Recent, it is not as common as in the Cretaceous, and these may finally be recognized as distinct. The localities of our specimens are as follows:

Recent.-Albatross stations off the east coast of the United States and Brazil (rare specimens of the same general form as this species).

Pliocene-Belgium, Crag noir, Antwerp (very rare specimens which may be referred to this species at present).

Miocene.--"Green clay," Cipero section, Trinidad (a single specimen referred to this species).

Oligocene.-Germany, Ahnatal, near Cassel; Hermsdorf, near Berlin; Söllingen; Düsseldorf.

Eocene.-South of Hospital Hill, San Fernando, Trinidad, British West Indies.

Cretaceous.-England, Chalkmarl, Folkestone; Saxon Cement Works, Cambridge; Cambridge Greensand, Saxon Cement Works, Cambridge; Gault, Folkestone; Barnwell Pit, Cambridge. Germany, upper Senonian, Dasbeck, near Hanover, Westphalia; Turonian, Birkwitz, near Pirna. Mexico, Velasco Shale, Hacienda El Limon, near Panuco.

\section{PYRULINA THOUINI (d'Oribigny)}

Plate 14, figures $6 a-c$

Polymorphina thouini D'Orbigny, Ann. Sci. Nat., vol. 7, 1826, p. 265, No. 8; model No. 23.-H. B. Brady, PArker, and Jones, Trans. Linn. Soc., vol. 27, 1870, p. 232, pl. 40, fig. 17.-GoËs, Kongl. Svensk. Vet. Akad. Handl., vol. 25 , no. 9, 1894 , p. 59 , pl. 10, figs. 557-558.

Test attenuate, subcylindrical, almost circular in end view; chambers elongate, not much embracing, arranged at first in a nearly triserial series becoming biserial later, each succeeding chamber removed much farther from the base; sutures slightly depressed, distinct; wall smooth, translucent; aperture radiate.

Length $0.65-0.95 \mathrm{~mm}$; breadth $0.20-0.25 \mathrm{~mm}$.; thickness $0.18-$ $0.25 \mathrm{~mm}$.

Pyrulina thouini is one of the best defined species of Pyrulina, and is closely related to the widely distributed Pyrulina cylindroides, from which it may be derived by drawing out the slender fusiform chambers which are placed less obliquely, and accordingly the test becomes more elongate. Terquem's Polymorphina thouini from Vaudancourt somewhat resembles d'Orbigny's species, but we should hesitate to place it under the synonymy of the present species, as it has much depressed sutures.

We have examined material from the Paris Basin, and obtained some excellent specimens coinciding well with the model of d'Orbigny. The original specimen is lost. 
Distribution.-We have specimens in our collection from the Eocene of France from Grignon and Damery.

\section{PYRULINA ACUMINATA d'Orbigny}

Plate 14, figures $7 a-c$

Pyrulina acuminata D’Orbigny, Mém. Soc. Géol. France, 1840, p. 43, pl 4, figs. 18, 19.-Reuss, in Geinitz, Grundr. Verstein., 1845-46, p. 670, pl. 24, fig. 64.-D'Orbigny, Prodrome de Paleont., vol. 2, 1850, p. 282, No. 1405.-Reuss, Haidinger's Nat. Abhandl., vol. 4, 1851, p. 26.-Beissel, Abhandl. kön. Preuss. geol. Landes., n. ser., vol. 3, 1891, p. 63, pl. 10, figs. 54-59.

Pyrulina ovulum Ehrenberg, Mikrogeologie, 1854, pl. 31, figs. 35, 36.

Polymorphina acuminata H. B. Brady, PARKer, and Jones (not d'Orbigny), Trans. Linn. Soc., vol. 27, 1870, p. 219, pl. 39, figs. $4 a$, b.-EgGeR, Abhandl. kön. bay. Akad. Wiss. München, Cl. II, vol. 21, pt. 1, 1899, p. 130 , pl. 17, fig. 3 .

Polymorphina (Pyrula) acuminata Egger, Ber. nat. Ver. Passau, 1907, p. 40 , pl. 4 , fig. 27.

Test ovate-elongate to fusiform, both ends acuminate; chambers inflated, much embracing, arranged in a nearly triserial series in the early stages, becoming biserial later; sutures not depressed, difficult to recognize; wall smooth; aperture produced, radiate.

Length $0.80-1.30 \mathrm{~mm}$; breadth $0.28-0.50 \mathrm{~mm}$; thickness $0.25-$ $0.50 \mathrm{~mm}$.

In some of its characters, Pyrulina acuminata bears some resemblance to Pyrulina porrecta, but the latter has generally a much more slender test, the chambers scarcely overlapping, and is not as compactly built as is the present species. Both extremities are strongly acuminate, a very characteristic feature of the species.

Distribution.-Not rare in Cretaceous deposits, but very rare in the earlier Tertiary. We have specimens of Pyrulina acuminata from the following localities: France, Upper Cretaceous, Chalk, Bougival. Germany, Upper Senonian, Rinkerode and Dasbeck, both in Westphalia. We have a series of specimens from the lower Tertiary of San Fernando, Trinidad, British West Indies, collected by P. W. Jarvis, which seem identical with this species. The series contains slightly compressed as well as normal specimens and several that are fistulose.

PYRULINA ALBATROSSI Cushman and Ozawa, new species

Plate 15, figures 1-3

Test elongate, fusiform to cylindrical, acute at both ends; chambers elongated, much embracing, arranged in a triserial series, becoming biserial later, but often one extra, rounded chamber added at the top of the test, each succeeding chamber slightly removed from the base; sutures but little depressed, nearly vertical, generally distinct; wall smooth, thin, almost transparent; aperture radiate. 
Holotype, length $1.85 \mathrm{~mm}$; breadth $0.65 \mathrm{~mm}$.; thickness $0.40 \mathrm{~mm}$. Holotype.-(Cat. No. 20952, U.S.N.M.) From Albaiross D2160, 167 fathoms off Cuba.

In its general appearance it closely resembles Pyrulina cylindroides, but most of its sutures are almost vertical instead of oblique. It has often one extra chamber added at the top of the main test. In such a case, the suture of this extra chamber can not be distinguished from the others because of its similar appearance.

Distribution.- In addition to the type locality, we have specimens from Albatross D2756, 417 fathoms, coast of Brazil, and D2105, 1,395 fathoms, east coast of United States. There is a specimen also from Nero 613 in the Pacific that is close to the present species.

\section{PYRULINA RETICULOSA Cushman and Ozawa}

Plate 15 , figures $4 a, b$

Pyruilina reticulosa Cushman and Ozawa, Jap. Journ. Geol. Geogr., vol. 6, 1929, p. 69 , pl. 15 , fig.1.

Test elongate, elliptical, irregular in form, nearly circular in transverse section; chambers few, apparently three in the type specimen; sutures obscured by the ornamentation which consists of generally longitudinal costae with transverse ones between, making an irregular reticulation; aperture radiate.

Length $0.70 \mathrm{~mm}$.; breadth $0.33 \mathrm{~mm}$.

Holotype.-(Cat. No. 20312, U.S.N.M.) From Albatross D4882, Blake Reef off Vagadosaki Lighthouse, 248 fathoms.

This species is unique in its ornamentation. It may represent an intermediate between Globulina and Pyrulina.

\section{PYRULINA VELASCOENSIS (Cushman)}

Plate 29, figures $1 a-c$

Polymorphina velascoensis Cushman, Bull. Amer. Assoc. Petr. Geol., vol. 10, 1926, p. 604, pl. 20, figs. $16 a, b$.

Test elongate, fusiform in front view, in side view with the sides unequal, one side convex, the other concave, the concave side in front view with a central depression; chambers not elongated, rather compressed, arranged in a biserial series; sutures not at all depressed, very indistinct; wall smooth; aperture radiate.

Length $0.70 \mathrm{~mm}$.; breadth $0.25 \mathrm{~mm}$.; thickness $0.18 \mathrm{~mm}$.

This is a very peculiarly curved species having a longitudinal central depression.

Distribution.-This species is from the Velasco shale of the Tampico embayment, Mexico. 


\section{Genus GLOBULINA d'Orbigny, 1826}

\section{GLOBULINA GIBBA d'Orbigny}

Plate 16, figures 1-4

Globulina gibba D'Orbigny, Ann. Sci. Nat., vol. 7, 1826, p. 266, No. 10, Modèles No. 63; Foram. Foss. Bass. Tert. Vienne, 1846, p. 227, pl. 13, figs. 13, 14.-Terquem, Essai Class. Anim. Dunkerque, 1875, p. 38, pl. 5, fig. 15; Mém. Soc. Géol. France., sér 3, vol. 1, 1878, p. 43, pl. 4 (9), figs. 1-5; vol. 2 , 1882, p. 130, pl. 13 (21), figs. 22-27.-Jones and Chapman, Journ. Linn. Soc. Zool., vol. 25, 1896, pp. 509, 515, figs. 6, 7, 40 (in text).

Polymorphina (Globulina) gibba EGGER, Neues Jahrb. für Min., Jahrg. 1857, p. 289, pl. 13, figs. 1-4.-Andreat, Abhandl. Geol. Special-Karte ElsassLothringen, vol. 2, pt. 3, 1884, pp. 117, 141, pl. Ix, figs. 10-12, $13 a, b$.

Polymorphina gibba H. B. Brady, Parker, and Jones, Trans. Linn. Soc., vol. 27, 1870, p. 216, pl. 39, figs. $2 a, b$.-Reuss, Sitz. Akad. Wiss. Wien, vol. 62 , pt. 1, 1870, p. 485.-v. Schlicht, Foram. Septar. Pietzpuhl, 1870, pl. 27, figs. 1-6, 16-18; pl. 26, figs. 31-34.-H. B. Brady, Rep. Voy. Challenger, Zoology, vol. 9, 1884, p. 561, pl. 71, figs. $12 a, b$. -SHerborN and Chapman, Journ. Roy. Micr. Soc., ser. 2, vol. 6, 1886, p. 755, pl. 16, fig. 5.-GoËs, Kongl. Svensk. Vet. Akad. Handl., vol. 25, no. 9, 1894, p. 55, pl. 9, figs. 520-526.-Jones, Foram. Crag, pt. 3, 1896, p. 253, pl. 1, figs. 49-51.-Jones and Chapman, Journ. Linn. Soc. Zool., vol. 25, 1896, pp. 513, 514, figs. 31-33 (in text).-BAGG, Maryland Geol. Surv. (Eocene), 1901, p. 248, pl. 63, fig. 12; (Miocene), 1904, p. 477, pl. 133, fig. 4.-Weller, Geol. Surv. New Jersey, Paleontology, vol. 4, 1907, p. 250, pl. 3, fig. 21.-Sideвоттом, Mem. Proc. Manchester Lit. Philos. Soc., No. 9, vol. 51, 1907, p. 10, pl. 2, figs. 15-17.-PaAlzow, Ber. Offenb. Ver. Nat., 1912, p. 67, pl. 1, fig. 10.-Cushman, U. S. Geol. Surv. Bull. 676, 1918, pp. 10, 52, pl. 2, fig. 4; pl. 11, fig. 5; Prof. Paper 129-F, 1922, pp. 93, 94, pl. 17, fig. 3; pl. 18, figs. $3 a$, b.-Plummer, Bull. 2644, Univ. Texas, 1927, p. 122, pl. 6, figs. $8 a$, b.-Stadnichenko, Journ. Pal., vol. 1, 1928, p. 230, pl. 38, figs. 20-22.

Gutiulina (Globulina) gibba Cushman, Bull. Soc. Sci. Seine-et-Oise, ser. 2, vol. 9,1928, p. 50 , pl. 1 , figs. $4 a-c, 5 a, b$. (Separate, p. 4, pl. 1, figs. $4 a-c, 5 a, \mathrm{~b})$.

Globuitina globosa Reuss (not Münster) in Geinitz, Grundr. Verstein., 1845-46, p. 669, pl. 24, fig. 85; Sitz. Akad. Wiss. Wien, vol. 44, pt. 1, 1861 (1862), p. 318, pl. 3, fig. 3 .

Globulina tubulosa D'Orbigny, Foram. Foss. Bass. Tert. Vienne, 1846, p. 228, pl. 13, figs. 15,16 .

Polymorphina (Globulina) gibba D'Orbigny var. ovoidea EgGer, Neues Jahrb. für Min., Jahrg., 1857, p. 289, pl. 13, figs. 5-7.

Polymorphina (Globulina) gibba D'Orbigny var. subgibba EgGer, Neues Jahrb. für Min., Jahrg., 1857, p. 289, pl. 13, figs. 8-10.

Polymorphina (Globulina) gibba D'Orbigny var. pirula Egger, Neues Jahrb. für Min., Jahrg., 1857, p. 290, pl. 13, figs. 11, 12.

Globulina amplectens Bornemann (not Reuss), Zeitschr. Deutsch. geol. Ges., vol. 12,1860, p. 160 , pl. 6 , figs. 12 a-c.

Polymorphina gibba D'Orbigny var. orbicularis Karrer, Sitz. Akad. Wiss. Wien, vol. 58, abt. 1, 1868, p. 174, pl. 4, fig. 8 .

Globulina subgibba Gümbel, Abhandl. kön. bay. Akad. Wiss. München, Cl. II, vol. 10,1870 , p. 645 , pl. 2 , fig. 79 . 
Globulina ovalis Terquem, Essai Class. Anim. Dunkerque, 1876, p. 77, pl. 10, fig. 2.

Globulina oviformis Terquem, Mém. Soc. Géol. France, sér. 3, vol. 1, 1878, p. 44 , pl. 4 (9), figs. 9-12.

Globulina transversa Terquem, Mém. Soc. Géol. France, sér. 3, vol. 2, 1882, p. 129 , pl. 13 (21), figs. 17-21.

Guttulina ponderosa Terquem, Mém. Soc. Géol. France, sér. 3, vol. 2, 1882, p. 135 , pl. 14 (22), fig. $1 a, b$.

Guttulina gravida Terouem and Terquem (not Terquem 1878), Bull. Soc. Zool. France, vol. 11, 1886, p. 334, pl. 11, fig. 21.

Polymorphina inflata Terquem and Terquem (not Terquem 1878), Bull. Soc. Zool. France, vol. 11, 1886, p. 335, pl. 11, fig. 23.

Polymorphina laciea (Walker and JACOB) var. diffusa Cushman, Bull. 71, U. S. Nat. Mus., pt. 3, 1913, p. 84, pl. 41, fig. 8.

Test globular to subglobular, transverse section almost circular; chambers few, inflated, rounded, arranged in a nearly triserial series; sutures not depressed, generally clear; wall smooth, translucent, often with fistulose tubes, especially at apertural end; aperture radiate.

Length $0.45-1.10 \mathrm{~mm}$.; breadth $0.40-0.90 \mathrm{~mm}$.; thickness 0.40 $0.90 \mathrm{~mm}$.

D'Orbigny's original specimen is lost.

Globulina gibba is definite in its general characters; still there are several distinct varieties, and many specific and varietal names are given by various authors to forms which seem merely variations of the typical.

D'Orbigny's model has a globular test, with a slightly produced apex. Egger's Polymorphina gibba var. pyrula represents a form with a much produced apex, and Gümbel's Globulina subgibba is typically spherical, while Karrer's Polymorphina gibba var. orbicularis has a spheroidal test, shorter than broad.

There are some individuals which can be compared with Egger's Polymorphina gibba var. ovoidea and subgibba and Terquem's Globulina oviformis, transversa, ponderosa, and inflata, in which the chambers are either unequally overlapped or not very regularly combined.

There are numerous fistulose forms, some of which are very elaborate and have been given different names, in which the main body of the test is typically Globulina gibba.

Distribution.-Globulina gibba is often recorded from the Jurassic and Cretaceous formations, but as far as our material is concerned there are no Mesozoic Globulina gibba.

The Cretaceous Globulinas having a more or less globular test are separated from Tertiary Globulina gibba, as is described in later pages. We have examined in our collection more than 1,200 specimens of Globulina gibba, and the distribution of these is given below. It is very noteworthy that of all these specimens the only Recent ones are from the Mediterranean and off Ireland. In the Pliocene the records are almost entirely from the same region. In the Miocene the dis- 
tribution is wide, as it is in the Oligocene and Eocene. Unlike many species of foraminifera, this species died out in the Pacific region and only persisted in the Atlantic and Mediterranean. The opposite is usually the case.

Recent.-Mediterranean, Tripoli; Lido, Venice; 10-14 fathoms, off island of Delos. Southwest of Ireland, dredged by steam tug "Lord Bandon," log. 28, 26 fathoms, off Baltimore, Ireland.

Pliocene.-England, Crag, Sutton. Belgium, Crag, Antwerp. Spain, Garrobo. Italy, Castel Arquato; Coroncina, near Siena. Lanarka, island of Cyprus. United States, Shell Creek, De Soto County, Fla.

Miocene.-Austria, Tortonian, Baden; Grunes Kreuz, near Nussdorf; Vosslau; Perchtoldsdorf. Hungary, Tortonian, Varpolata; Kostej; Bujtur, Siebenburgen; Lapugy. France, Helvetian, Pontlevoy; Moulin de Minoy, Salles; Aquitanian superieur, La Brede Larriey, near Bordeaux; St. Avit; Aquitanian inferieur, La Brede, rauche de Chemin de Fer; Burdigalien superieur, Merignac; Pont Gourguet, Saucats; Burdigalien moyen, Le Coquillat, Leognan; St. Paul de Dax, Dax; Burdigalien inferieur, Moulin de l'Eglise, Saucats. Germany, Ortenberg. Australia, Janjukian, Filter quarry, Batesford, Victoria; green marl, Bird Rock Cliffs, Torquay, Victoria; Danger Point, Torquay, Victoria; Balcombian, Kackeraboite Creek. United States. Duplin marl, Marysville, S. C.; Choctawhatchee marl, 1 mile east of Red Bay, Walton County, Fla.; Chipola marl, Chipola River, Calhoun County, Fla.

Oligocene.-Germany, Upper Oligocene. Ahnatal, near Cassel. Middle Oligocene, Söllingen, Hermsdorf, near Berlin; Wiesloch near Heidelberg; Egisheim. Lower Oligocene, Lattdorf. United States, lower Oligocene, Byram marl, Mississippi; upper fossiliferous zone, 600-700 feet north of bridge over Glass Bayou, Vicksburg; PearI River at bridge at Byram; Chickasawhay River at wagon bridge, onefourth mile west of Woodward, 2 miles northwest of Waynesboro; 500 feet west of bridge, $2 \frac{1}{2}$ miles south of Waynesboro; road north of National Cemetery, Vicksburg; Leaf River, one-half mile below bridge on Taylorsville-Silvarena Road, near old Blakney post office; calcareous sands, railroad cut east of Brandon; Glendon limestone, Mississippi, below waterfall in Glass Bayou, Vicksburg; Robinson's quarry, 4 miles east of Brandon, Ala.; west bank of Conecuh River at McGowan's bridge, about 1 mile below mouth of Sepulga River; Tiger Hill, east bluff of East Tallahala Creek, sec. 7, T. 1 N., R. 12 E., 10 miles in air line south by east of Bay Springs, Miss.; Marianna limestone, Mississippi, 1 1/2 miles southsoutheast of Heidelberg; $1 \frac{1}{2}$ miles northeast of Brandon; Bay Springs, Tallahala Road east of Tallahala Creek; $2 \frac{1}{2}$ miles northeast of Calmar post office. Ala. $2 \frac{1}{2}$ miles north of Millry; St. Stephens Bluff, right bank of Tombigbee 
River, about 9 miles above Jackson; gully west of road from Perdue Hill to Claiborne, 250 feet above Alabama River; east end of wagon bridge on Murder Creek, east of Castleberry; $2 \frac{1}{2}$ miles southwest of Whatley; near head of branch about 1 mile east by south of Fail, about 300 yards north of road from Isney to Healing Springs; Mint Spring marl, Mississippi, below waterfall at Glass Bayou, Vicksburg; foot of waterfall in Mint Spring Bayou, Vicksburg; Chickasawhay River, 1 1 $\frac{1}{4}$ miles northwest of mouth of Limestone Creek, 4 miles northwest of Waynesboro; Brown's Cave, east bluff of Leaf River, Smith County; Red Bluff clay, Mississippi, old Red Bluff Landing on Chickasawhay River at Hiwanee, $3 \frac{1}{2}$ miles south of Shubuta, Ala.; St. Stephens Bluff, right bank of Tombigbee River, about 9 miles above Jackson, bed 3 of section; near head of small branch about 1 mile southeast of Fail, Ala. Mexico, Huasteca Railroad, between kilometers 9 and 10, 1 kilometer east of Big Cut, Tampico region.

Eocene.-England, Bracklesham bed XVII, White Cliff Bay, Isle of Wight. France, Lutetien, Vaudancourt, Parnes (Les Bôves), Grignon, Courtagnon, Damery, Chaussy, Campbon. Austria, Bartonian, Bruderdorf, bei Stockerau. Italy, Bartonian, Val di Lonte. Germany, Hammer, upper Bavaria. Belgium, lower Eocene, Wansin. Mexico, Guayabal formation, Guayabal. Trinidad, Cipero section. United States, Jacksonian, Alabama; Conecuh River at Beck, Covington County; $3 \frac{1}{4}$ miles north of Grove Hill, on road to Thomasville, Clarke County; road from Perdue Hill to Claiborne, Monroe County; east bank of Sepulga River, about 4 miles northeast of Brooklyn, Conecuh County; Powell's Landing, east bank of Sepugla River, sec. 35, T. 4 N.; R. 13 E., Covington County, road from Bladen Springs to Millry, about $3 \frac{1}{2}$ miles southeast of Cullomburg. Mississippi, roadside on hill above pumping station at Jackson; bluff on Garlands Creek, about 5 miles northeast of Shubuta, Quitman County. Florida, Ocala limestone, on road near Blue Springs, 6 miles northeast of Marianna, Jackson County; west bank of Chipola River, at wagon bridge, east of Marianna; quarry of Florida Lime Co., on southwest edge of Ocala, Marion County; phosphate mine, $1 \frac{1 / 2}{2}$ miles west of Croom, Hernando County. Georgia, 5 miles north of Millen, Jenkins County; east bank of Flint River, at bar three-fourths mile northeast of Atlantic Coast Line Railroad station at Bainbridge; Rich Hill, Crawford County, 6 miles southeast of Roberta. South Carolina, Cooper marl, Ingleside marl pit, Charleston; Mill Creek, Beldock, Barnwell County; steep bluff, west side of Biggin Creek, three-fourths mile below the Coastal Highway, Berkeley County; highway, 173/4 miles west of old Biggin Church, Berkeley County; dump heap from Charleston Aqueduct, 1 mile west of Givhan's Dorchester County. 
Claibornian, New Jersey, Vincentown. Alabama, right bank of Tombigbee River at bend about 1 mile above St. Stephens Bluff, Washington County. Midwayan, Tex.

GLOBULINA GIBBA d'Orbigny var. GLOBOSA (v. Münster)

Plate 17, figures 8,9

Polymorphina globosa v: MÜNster, in Roemer, Neues Jahrb. f. Min., etc., 1838 , p. 386 , pl. 3, fig. 33.-REuss, Die Verstein. böhm. Kreide., 1845, p. 40, pl. 13, fig. 82.-EGGER, Abhandl. kön. bay. Akad. Wiss. München, Cl. II, vol. 21, pt. 1, 1899, p. 129, pl. 17, fig. 26.

Polymorphina acuia Roemen, Neues Jahrb. f. Min. etc., 1838, p. 386, pl. 3, fig. 36.

Globulina acuta Reuss, Sitz. Akad. Wiss. Wein, vol. 18, 1855 (1856), p. 245, pl. 6 , fig. 62 .

Globulina aequalis D'Orbigny, Foram. Foss. Bass. Tert. Vienne, 1846, p. 227, pl. 13, figs. 11, 12 .

Polymorphina equalis Cushman, U. S. Geol. Survey Prof. Paper 129-F, 1922, p. 132, pl. 31, fig. 3; Bull. 104, U. S. Nat. Mus., pt. 4, 1923, p. 149, pl. 40, fig. 3.

Polymorphina gibba var. aequalis H. B. Brady, PARKer, and Jones, Trans. Linn. Soc., vol. 27,1870 , p. 216, pl. 39, figs. $2 c, d$.

Globulina turbinata Terquem, Mém. Soc. Géol. France., sér. 3, vol. 1, 1878, p. 43 , pl. 4 (9), figs. $6-8$.

Test subglobular to broadly oval, rather convex on one side in the microspheric form, more or less equally compressed in the megalospheric form, slightly produced at the apertural end; chambers more or less compressed, generally up to seven in the microspheric, four in the megalospheric form, the later chambers more embracing on one side, arranged in an almost triserial series, each succeeding chamber more or less above the base; sutures not depressed, distinct; wall smooth, thick, often with fistulose tubes; aperture radiate.

Length $0.65-0.90 \mathrm{~mm}$.; breadth $0.40-0.65 \mathrm{~mm}$.; thickness $0.20-0.35$ $\mathrm{mm}$.

This is a compressed modification of Globulina gibba, and there is a certain range of variation in its test.

Globulina acuia (Roemer), from the German Oligocene has a rather elongated test with an acuminate apertural end, and in Globulina turbinata Terquem the test is rhombic with rounded edges.

Globulina aequalis d'Orbigny, of which both the originals and paratypes were examined by Ozawa, shows a wide range of variation in its shape.

Distribution.-Like Globulina gibba and Globulina inaequalis, the present variety is widely distributed both geologically and geographically. We have specimens from the following localities:

Recent.-Atlantic off Nymph Bank, South of Cork Harbor, Ireland, $52 \frac{1}{2}$ fathoms; Dogs Bay, Ireland; coast of Iceland. Mediterranean, Rimini, Italy. Pacific, shore sand, Torquay, on Bass Strait, Victoria, Australia. 
Pliocene.-Belgium, Crag noir, Antwerp. Italy, Castel Arquato. Miocene.-France, Aquitanian superieur, Mont de Marson, St. Avit; Burdigalien moyen, Le Coquillat, Leognan; Burdigalien inferieur, Moulin de l'Eglise, Saucats. Austria, Tortonian, Amphistegina marl, Grunes Kreuz, Nussdorf, near Vienna; Perchtoldsdorf, near Vienna; Bujtur, Siebenburgen. Hungary, Tortonian shell sand, Varpolata; Kostej, Banat; Lapugy. United States, Choctawhatchee marl, three-fourths mile east of Red Bay, Walton County, Florida.

Oligocene.-Germany, Ahnatal, near Cassel; Doberg, near Bünde; Flonheim, Mainz Basin; Cothen; Hildesheimer Wald, Dickholzen; Hermsdorf, near Berlin. Mexico, near Cuesta Blanca, Zacamixtle, Vera Cruz.

Eocene.-England, Bracklesham beds, from material washed upon beach at Selsey. Austria, Bartonian, Bruderndorf, near Stockerau. United States, Wilmington, N. C.; Cooper marl, Ashley, Dorchester County, S. C.; Steep Bluff, west side of Biggen Creek, three-fourths mile below Coastal Highway, Berkeley County, S. C.; Vincentown, N. J.

\section{GLOBULINA GIBBA d'Orbigny var. COGNATA (Franzenau)}

Plate 19, figures $8 a-c$

Polymorphina cognata Franzenad, Glasnick. Kra. nav. Druztva God., vol. 6,1894 , p. 35 , pl. 6 , fig. 59 .

Variety differing from the typical form in having the spine at the initial end. Length of figured specimen $0.55 \mathrm{~mm}$.; breadth $0.40 \mathrm{~mm}$.; thickness $0.40 \mathrm{~mm}$.

Recent.-Mediterranean, off Island of Delos, 10-14 fathoms.

Pliocene.-Sepik River, Borneo.

\section{GLOBULINA GIBBA d'Orbigny var. STRIATA Egger}

Plate 16 , figures $5-7$

Polymorphina (Globulina) striata EgGer, Neues Jahrb. für Min., Jahrg. 1857, p. 291, pl. 14, figs. 3, 4.

Polymorphina (Globulina) costata EgGer, Neues Jahrb. für Min., Jahrg. 1857, p. 291, pl. 14, figs. 5, 6.

Polymorphina costata H. B. Brady, Parker, and Jones, Trans. Linn. Soc., vol. 27,1870 , p. 240 , pl. 41 , figs. $31 a, b$.

Variety with the test not compressed, often somewhat longer than broad, wall thick, translucent, ornamentation of the surface consisting of longitudinal, platelike costae, independent of the sutures, each broken into numerous irregular, jagged portions; apertural end usually broadly rounded.

Length $0.30-0.40 \mathrm{~mm}$.; breadth $0.20-0.33 \mathrm{~mm}$.; thickness $0.18-0.30$ $\mathrm{mm}$.

We have examined Egger's paratypes of Polymorphina (Globulina) striata and Polymorphina (Globulina) costata, together with other $92709-30-5$ 
European Miocene material, and find all gradations between these forms. The platelike costae, broken into numerous irregular, jagged portions are very characteristic of the variety, and by this character Globulina gibba var. striata can easily be distinguished from the allied forms such as Globulina gibba var. ornata (Karrer), and var. myristiformis (Williamson).

Plate 16, figure 5, is from a paratype of Egger's, and figure 7 is from, Ortenburg, Germany.

\section{[GLOBULINA GIBBA d'Orbigny var. MYRISTIFORMIS (Williamson)}

Plate 16, figures $8 a, b$; Plate 20, figures $6 a, b$

Polymorphina myristiformis Williamson, Recent Foram. Great Britain, 1858 , p. 73 , pl. 6 , figs. $156-157$.-H. B. Brady, Trans. Linn. Soc. Zool., vol. 24, 1864, p. 473 (table).-H. B. Brady, PARKer, and Jones, Trans. Linn. Soc., vol. 27,1870 , p. 240 , pl. 41 , figs. $30 a-c .-H$. B. BrADY, Rep. Voy. Challenger, Zoology, vol. 9, 1884, p. 571, pl. 73, figs. 9, 10.Balk will and Millett, Journ. Micr., vol. 3, 1884, p. 16, pl. 4, fig. 10.BALKwILl and Wright, Trans. Roy. Irish. Acad., vol. 28, Sci., 1885, p. 346.-H. B. Brady, Journ. Roy. Micr. Soc., 1887, p. 914.-Wright, Proc. Roy. Irish Acad., ser. 3, vol. 1, 1891, p. 487.-Robertson, Trans. Nat. Hist. Soc. Glasgow, vol. 3, pt. 3, 1889-92, p. 241.-Wright, Irish Nat., vol. 9, no. 3, 1900, p. 55.-Sideвоттом, Mem. Proc. Manchester Lit. Philos. Soc., No. 9, vol. 51, 1907, p. 13, pl. 3, fig. 7.-Millett, Recent Foram. Galway, 1908, p. 6, pl. 4, fig. 10.-Heron-Allen and Earland, Journ. Roy. Micr. Soc., 1909, p. 434; 1911, p. 324; Proc. Roy. Irish Acad., vol. 31, pt. 64, 1913, p. 103, pl. 8, figs. 18, 19; Journ. Roy. Micr. Soc., pt. 1, 1916, p. 48; Trans. Linn. Soc. London, vol. 11, ser. 2, 1916, p. 265; Bull. Soc. Sci. Hist. Nat. Corse, 1922, p. 131.-Cushman, Bull. 104, U. S. Nat. Mus., pt. 4, 1923, p. 158, pl. 41, figs. 9-12.

Polymorphina sulcata D'ORBigny, Ann. Sci. Nat., vol. 7, 1826, p. 266, No. 21.-Fornasini, Mem. Accad. Sci. Istit. Bologna, ser. 5, vol. 10, 1902, p. 52 , fig. 52 .

Variety having the wall marked by numerous longitudinal costae usually interrupted at the sutures and occasionally broken, especially in the basal area.

Length $0.30-0.40 \mathrm{~mm}$; breadth $0.25-0.35 \mathrm{~mm}$; thickness $0.25-$ $0.35 \mathrm{~mm}$.

Globulina sulcata, named by d'Orbigny in 1826, but figured much later by Fornasini, is undoubtedly the same as the present variety.

There are specimens in our collections from the following:

Recent.-Ireland, Steam Tug Lord Bandon, log. 33, Nymph Bank, south of Cork, 52 fathoms; log. 11, southwest of Ireland, 38-44 fathoms. England, off Plymouth. Italy, beach, Lido, Venice.

Pliocene.-England, Crag of Sutton. Italy, Castel Arquato.

Miocene.-Austria, Baden and Nussdorf.

Eocene.-France, Lutetien moyen, Grignon.

It may be noted that specimens from the Eocene of Grignon have very heavy costae as do also those of the Crag of Sutton. 
GLOBULINA GIBBA d'Orbigny var. ORNATA (Karrer)

\section{Plate 16, figure 9}

Polymorphina ornata KARrer, Sitz. Akad. Wiss. Wien, vol. 58, abt. 1, 1868, p. 175 , pl. 4, fig. 10.-H. B. Brady, PARKer, and Jones, Trans. Linn. Soc., vol. 27,1870 , p. 242 , pl. 41 , figs. $34 a, b$.

Variety ornamented with slightly raised warts or tubercles in more or less regular lines parallel to the long axis of the test.

Length $0.45-0.75 \mathrm{~mm}$; breadth $0.35-0.65 \mathrm{~mm}$; thickness $0.35-$ $0.65 \mathrm{~mm}$.

In the parallel arrangement of the broken costae, the present variety resembles var. granulosa, but it has a much coarser ornamentation. From Globulina gibba var. myristiformis, which has parallel broken costae, it is often very difficult to separate the present variety because of the intermediate forms. The variety is very abundant at Varpolata. The Eocene specimens are somewhat doubtfully of this variety, as is also that of Ahnatal.

We have specimens from the following localities:

Miocene.-Tortonian: Hungary, Varpolata; Kostej, Banat. Austria, Voslau brickyard, near Baden, near Vienna.

Oligocene.-Upper: Germany, Ahnatal, near Cassel (?).

Eocene.-Lutetien: France, Campbon (?).

GLOBULINA GIBBA d'Orbigny var. VERRUCOSA Cushman and Ozawa, new variety

Plate 17, figures $2 a, b$

Polymorphina ornata Heron-Allen and Earland (not Karrer), Journ. Roy. Micr. Soc., 1909, p. 434, pl. 17, fig. 8.

Variety differing from the typical in ornamentation of the surface which consists of thick wart-like, raised areas, arranged generally in longitudinal lines.

Holotype: Length $0.35 \mathrm{~mm}$; breadth $0.33 \mathrm{~mm}$; thickness 0.33 $\mathrm{mm}$.

Holotype-(Cushman Coll. No. 11421.) From the Lutetien, Campbon, in France.

Polymorphina ornata described and figured by Heron-Allen and Earland from Selsey Bill, Sussex, England is identical with the present variety.

GLOBULINA GIBBA d'Orbigny var. FISSICOSTATA Cushman and Ozawa, new variety

Plate 17 , figures $3 a, b$

Variety differing from the typical in the ornamentation which consists of numerous fine, broken, longitudinal costae covering the entire surface.

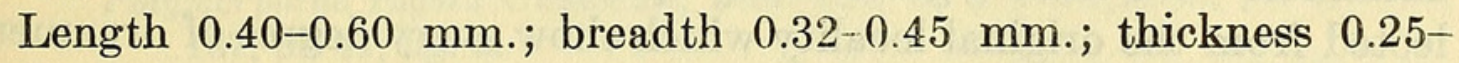
$0.38 \mathrm{~mm}$. 
Holotype of variety.-(Cushman Coll. No. 11398.) From the upper Oligocene of Ahnatal, near Cassel, Germany, where the variety is very abundant. We have a single specimen from the Pliocene of Castel Arquato, Italy, that may belong to this variety.

GLOBULINA GIBBA d'Orbigny var. LONGITUDINALIS Cushman and Ozawa, new variety

Plate 18, figures $1 a, b$

Variety differing from the typical form in its slightly compressed elongated test and its numerous, distinct, longitudinal costae. In its shape it is similar to Globulina gibba var. globosa, but it is ornamented by costae.

Holotype: Length $0.55 \mathrm{~mm}$; breadth $0.38 \mathrm{~mm}$; thickness 0.25 $\mathrm{mm}$.

Holotype of variety.-(Cushman Coll. No.11422.) From the Pliocene, Castel Arquato, Italy.

GLOBULINA GIBBA d'Orbigny var. TUBERCULATA d'Orbigny

Plate 17 , figures 6,7

Globulina tuberculata D'Orbigny, Foram. Foss. Bass. Tert. Vienne, 1846, p. 230, pl. 13, figs. 21, 22.-Terquem, Mém. Soc. Géol. France, sér. 3, vol. 2 , 1882, p. 132 , pl. 13 (21), figs. 33,34 .

Polymorphina (Globulina) tuberculata EgGER, Neues Jahrb. für Min., Jahrg. 1857 , p. 292 , pl. 14 , figs. $7,8$.

Polymorphina tuberculata H. B. Brady, PARKer, and Jones, Trans. Linn. Soc., vol. 27, 1870, p. 242, pl. 41, fig. 35 a-d.-Jones, Foram. Crag, pt. 3, 1896, p. 273, pl. 5, fig. 29.-Cushman, Bull. Amer. Assoc. Petr. Geol., vol. 10,1926 , p. 603 , pl. 20 , fig. 5 .

Globulina spinosa D'OrBigny, Foram. Foss. Bass. Tert. Vienne, 1846, p. 230, pl. 13, figs. 23, 24.-Terquem, Mém. Soc. Géol. France, sér. 3, vol. 2, 1882 , p. 132 , pl. 13 (21), fig. 35.

Polymorphina (Globulina) spinosa EGGer, Neues Jahrb. für Min., Jahrg. 1857 , p. 292, pl. 14, figs. 9, 10.

Polymorphina spinosa H. B. Brady, PARKer, and Jones, Trans. Linn. Soc., vol. 27,1870 , p. 243 , pl. 42 , figs. $36 a$, b.-BALKWILL and Wright, Trans. Roy. Irish Acad., vol. 28, Sci., 1885, p. 347, pl. 12, fig. 27.Cushman, U. S. Geol. Surv. Prof. Paper 129-F, 1922, p. 133, pl. 31, fig. 5; Bull. 104, U.S. Nat. Mus., pt. 4, 1923, p. 157, pl. 41, figs. 1, 13.

Globulina asperula GüMBeL, Abhandl. kön. bay. Akad. Wiss. München, Cl. II, vol. 10, 1870, p. 646 , pl. 2, figs. $81 a, b$.

Polymorphina frondiformis Searles Wood var. brevis Jones, Crag Foram., Pal. Soc. Mon. 19, 1866-1897, p. 271, pl. 7, fig. 20.

Variety ornamented with strong spines of unequal size and irregularly spaced. Ozawa examined the original specimens of Globulina tuberculata and G. spinosa, which show no special difference excepting the size of the tubercles or spines, which are not equal even in an individual specimen. d'Orbigny figured forms of both extremes. We have a great many specimens of these two forms collected from the original locality which show every degree of ornamentation between d'Orbigny's two species. 
Length with spines $0.70-0.90 \mathrm{~mm}$; breadth $0.60-0.80 \mathrm{~mm}$; thickness $0.50-0.70 \mathrm{~mm}$.

Globulina asperula as described by Gümbel, having tubercles uniformly distributed, is undoubtedly the same as the present variety.

Polymorphina frondiformis var. brevis, recorded from the Crag by Jones, is described as having a subovate test with somewhat round chambers ornamented with irregular and subquadrate droplike beads and is evidently identical with the present variety tuberculaia.

Ozawa examined d'Orbigny's specimens of Globulina tuberculata and spinosa in Paris and Vienna and is certain that they were obtained from Nussdorf and not Baden, as d'Orbigny records. The specimens show the same appearance as our Nussdorf specimens.

Distribution.-Specimens are in our collections from the following localities:

Pliocene.-Italy, Castel Arquato. England, Crag of Sutton.

Miocene.-Austria, Tortonian, Amphistegina marl of Grunes Kreuz, Nussdorf, Vienna; Ziegelgrube, Baden. Hungary, Kostej, Banat. France, Helvetian, Salles, Moulin du Minoy.

Oligocene.-Germany, upper Oligocene, Ahnatal, near Cassel. United States, lower Oligocene, Byram marl, Mississippi, Leaf River, $1 / 2$ mile below bridge on Taylorsville-Silvarena road, near Old Blakney post office; Glendon limestone, Mississippi, from loose blocks of limestone below waterfall in Glass Bayou; Alabama, west bank of Conecuh River at McGowans Bridge, about 1 mile below mouth of Sepulga River; Mint Spring marl, Mississippi, below waterfall at Glass Bayou, Vicksburg; waterfall in Mint Spring Bayou, Vicksburg; Chickasawhay River, $1 \frac{11}{4}$ miles northwest of mouth of Limestone Creek, 4 miles northwest of Waynesboro.

Eocene.-Germany, Hammer, Upper Bavaria.

GLOBULINA GIBBA d'Orbigny var. PUNCTATA d'Orbigny

Plate 17, figures 4,5

Globulina punctata D'Orbigny, Foram. Foss. Bass. Tert. Vienne, 1846, p. 229, pl. 13, figs. 17, 18.

Polymorphina hirsuta H. B. Brady, Parker, and Jones, Trans. Linn. Soc., vol. 27,1870 , p. 243 , pl. 42 , fig. 37.-Reuss, Sitz. Akad. Wiss. Wien, vol. 62 , pt. 1, 1870, p. 486.-v. Schlicht, Foram. Septar. Pietzpuhl, 1870, pl. 34, figs. 1-3.-Jones and Chapman, Journ. Linn. Soc. Zool., vol. 25, 1896, p. 511, figs. $21 a$, b, (in text).-Jones, Foram. Crag, pt. 3, 1896, p. 273 , pl. 6, figs. $14 a$, b.-Heron-Allen and Earland, Journ. Roy. Micr. Soc., 1909, p. 435, pl. 17, fig. 7.-Franke, Abhandl. geol. pal. Instit. Univ. Greifswald, vol. 6, 1925, p. 79, pl. 6, fig. 22.

Globulina rugosa D'Orbigny, Foram. Foss. Bass. Tert. Vienne, 1846, p. 229, pl. 13, figs. 19, 20.-Terquem, Essai Class. Anim. Dunkerque, 1876, p. 77 , pl. 10, fig. 1 .

Polymorphina rugosa Cushman, Bull. 104, U. S. Nat. Mus., pt. 4, 1923, p. 157, pl. 41, fig. 6 .

Polymorphina globosa Karrer (not v. Münster), Sitz. Akad. Wiss. Wien, vol. 52 , abt. 1,1865 , p. 497 , pl., fig. 12 . 
Variety ornamented with small spines or punctations (not depressions, as described by d'Orbigny).

The original specimen in Paris is lost. Paratype specimens preserved in the geological department, Museum of Natural History in Vienna, are mostly Orbulina universa with a few Globulina gibba (some fistulose forms) and one specimen somewhat resembling the figure of Globulina punctata given by d'Orbigny. This is slightly elongated, just like a specimen in our collection from the Tortonian clay of Baden in the Vienna Basin. Brady, Parker, and Jones regarded Globulina punctata as representing a thin-walled condition in a shell of the common type of Globulina gibba, but the minute depressions on the surface noted by d'Orbigny are not depressions and do not represent the minute foramina in the chamber wall, but are surface ornamentations. Brady, Parker, and Jones separated the forms beset with fine spines as a distinct species, Polymorphina hirsuta, but such forms grade into typical variety punctata, and we think it is unnecessary to separate them.

Length $0.35-0.65 \mathrm{~mm}$; breadth $0.30-0.55 \mathrm{~mm}$.; thickness $0.30-0.55$ $\mathrm{mm}$.

D'Orbigny's Globulina rugosa, described as having a globular test marked by longitudinally arranged depressions, was considered by several authors to be the same as Polymorphina (not Globulina) rugosa, having a peculiar test beset with spines, but there is no data whether d'Orbigny considered them as synonyms. The original specimens of these two species are lost, but paratype specimens of Globulina rugosa are in the Museum in Vienna and were examined by Ozawa. They are mostly Globulina gibba with one Orbulina universa, and there is nothing like the form figured by d'Orbigny.

If the specimen has the feature as illustrated by d'Orbigny and characterized by small depressions arranged longitudinally, then Globulina rugosa is considered to be nothing but Globulina punctata. In the middle Miocene (Tortonian) clay in the Vienna Basin Ozawa collected some Globulina ornamented with broken but strong costae, which resemble Globulina myristiformis Williamson. They appear to be Globulina rugosa, but there is no original specimen, and the paratype specimens are all quite different from the figure, therefore it is more advisable to place Globulina rugosa as a synonym of Globulina gibba var. punctata d'Orbigny.

Distribution.-We have specimens referable to this variety from the following:

Recent.-Mediterranean, Shoresand, Rimini; Island of Delos, 14 fathoms.

Pliocene.-England, Crag of Sutton. Italy, Castel Arquato.

Miocene.-Austria, Tortonian, Ziegelgrube, Vöslau, Vienna Basin; Baden, Vienna; Perchtoldsdorf, near Vienna; Bujtur, Siebenburgen. 
Hungary, Lapugy. France, Helvetian, Moulin du Minoy, Salles; Burdigalien superior, Merignac (Gironde); Burdigalien moyen, Le Coquillat, Leognan; St. Paul de Dax, Dax.

Oligocene.-Germany, Ahnatal, near Cassel; Hildesheimerwald, Dickholzen; Doberg, near Bünde.

Eocene.-Lutetien, Parnes (Les Bôves); Lutetien, Grignon, Chaussy.

GLOBULINA GLACIALIS Cushman and Ozawa, new species

Plate 15, figures 6,7

Test fusiform, slightly more acute at the base than at the apertural end; chambers more or less inflated, longer than wide, embracing, arranged in a clockwise, nearly triserial series, each succeeding chamber but little removed from the base, often with an extra chamber added higher up on the test; sutures very slightly depressed, distinct; wall smooth, thin, almost transparent; aperture radiate.

Length $0.30-0.45 \mathrm{~mm}$; breadth $0.14-0.22 \mathrm{~mm}$; thickness $0.12-$ $0.18 \mathrm{~mm}$.

Holotype.-(Cushman Coll. No. 11456.) From Pleistocene clays of the Glen, Montreal, Canada.

In general aspect it resembles Globulina minuta of the European Tertiary, but its arrangement of chambers is in a clockwise spiral (almost triserial) series instead of contraclockwise, as in G. minuta. There are some specimens with one extra chamber which is invariably inflated and added higher up on the test, while in $G$. minuta an extra chamber shows no great difference in position from the others.

Distribution.-This species is a cold-water one found in the glacial clays of Canada and New England and living in very cold waters.

Recent.-Canada, Murray Bay, Province of Quebec.

Pleistocene.-Canada, glacial clays, the Glen, and McGill College Grounds, Montreal. United States, Leda clay, Portland, Me.

GLOBULiNA LANDESI (G. D. Hanna and M. A. Hanna)

Plate 15, figures $9 a, b$

Polymorphina landesi G. D. Hanna and M. A. Hanna, Publ. Geol. Univ. Washington, 1924, vol. 1, no. 4, p. 60, pl. 13, figs. 16, 17.

Test compressed, almost circular in outline except for the produced apertural end; chambers elongated, much embracing, arranged in a more or less triserial series, each succeeding chamber not removed from the base; sutures not depressed but distinct; wall smooth, rather thick; aperture produced, radiate.

Figured specimens: Length, $0.45 \mathrm{~mm}$; breadth, $0.35 \mathrm{~mm}$; thickness, $0.25 \mathrm{~mm}$.

The present species is one of the few Globulinas described from the Pacific region and was described from the Eocene of North America.

It is the only species of Globulina found in Japanese Recent and Tertiary material. It is characterized by an almost circular test, and 
the chambers are much embracing. European Globulina inaequalis has a compressed and rounded test, but not as regularly circular as the Japanese species. A young stage of Sigmomorphina semitecta resembles the present species, but it is more compressed and invariably elongated.

Distribution.-G. D. Hanna and M. A. Hanna described the present species from the Eocene in Lewis County, Wash. Japanese specimens are from shore sand, Kobama (Sea of Japan), Province of Echizen. We have a few specimens which are very similar to the present species from various European Tertiary deposits: Pliocene of Castel Arquato, Italy; Miocene, Burdigalien inferieur, Moulin de l'Eglise, Saucats, France; and Eocene, Lutetien, Parnes (Les Bôves), France. A specimen from the Tortugas, off Florida in 11 fathoms, is also very similar.

\section{GLOBULINA DENTIMARGINATA (Chapman)}

Plate 15, figures $10 a, b$

Polymorphina concava Williamson var. dentimarginata Chapman, Quart. Journ. Geol. Soc., vol. 50, 1894, p. 717, pl. 34, fig. $14 a, b$.-Jones and Chapman, Journ. Linn. Soc. Zool., vol. 25, 1896, p. 514, figs. $35 a, b$ (in text).

"Test adherent, flat on the attached and convex on the opposite face, subovate in outline, and sharply pointed at both ends on the upper and lower surfaces, in the central area of the test, is exhibited a regular Polymorphine series, consisting of five chambers on the upper surface, and surrounding this is a secondary or later growth of shell material, depauperate and thin, which appears to turn back upon the under surface, forming the adherent portion. The thin outer flangelike portion of the test shows the septation of five flattened segments. The delicate margin of the test is broken up into a fine pectinate edge, and by careful observation the surface is seen to be studded sparsely with minute prickles. Length, one thirty-eighth inch $(0.65 \mathrm{~mm}$.); width, one eighty-fifth inch $(0.30 \mathrm{~mm}$.)."

We have no specimen representing the present species. Considered from the original figures and descriptions, Globulina dentimarginata is quite different from Sigmomorpha concava in its arrangement of chambers and can be safely separated as a good species. The arrangement of chambers of the present species appears to be abnormal from that of a regular Globulina, considering this from the arrangement of chambers, and it seems to be a specialized globular species of Quadrulina, but we can not say anything definite without examining the original specimen. Therefore the present species is provisionally included in Globulina. The above description is copied in full from the original.

Chapman's specimens were from the Cretaceous, Bargate beds of Surrey, England. 


\section{GLOBULINA PRISCA Reuss}

Plate 12, figures $6 a-c$

Globulina prisca Reuss, Sitz. Akad. Wiss. Wien, vol. 46, pt. 1, 1862 (1863), p. 79 , pl. 9 , fig. 8 .

Polymorphina acuta Olszewski, Sprawozd. Kom. Fizyj. Ak. Umiej. Krakowie, vol. 9 , 1875, p. 120, pl. 1, fig. 13.

Polymorphina fusiformis Chapman (not Roemer), Journ. Roy. Micr. Soc., 1896, p. 11, pl. 2, fig. 9 (not fig. 10).

Test elongate, fusiform, more or less compressed, acuminate toward both ends; chambers elongate, tapering to the base, arranged in an almost triserial series; sutures but little depressed; wall smooth; aperture radiate.

Length, 0.50-0.80 mm.; breadth, 0.25-0.35 mm.; thickness, 0.18 $0.27 \mathrm{~mm}$.

This is one of the more common species among the Cretaceous Polymorphinidae. It resembles compressed Globulina minuta in the Tertiary, with which it may be confused, but Globulina prisca is always compressed and usually very slender, its later chambers generally coming down almost to the base, while in Globulina minuta the test is as a rule typically fusiform with a circular section and the later chambers removed farther from the base.

As Olszewski's Polymorphina acuta is not well drawn, we can not be positive without seeing the types, but it seems to be very close to Globulina prisca.

Distribution.-This species is fairly common in the Cretaceous of Europe and America. We have specimens as follows:

Cretaceous.-England, Cambridge greensand, Saxon Cement Works, Cambridge; chalk marl, Saxon Cement Works, Cambridge and Folkestone; lower Gault, Barnwell pit, Cambridge, and bed VI, Gault of Folkestone. Germany, upper Senonian. Dasbeck b. Hanover, Westphalia. Mexico, numerous specimens from Upper Cretaceous, Velasco shale, Hacienda El Limon, west of Panuco.

\section{GLOBULINA INAEQUALIS Reuss}

Plate 18, figures 2-4

Globulina inaequalis Reuss, Denkschr. K. Akad. Wiss. Wien, vol. 1, 1850, p. 377 , pl. 48 , fig. 9 .

Globulina discreta Reuss, Denkschr. K. Akad. Wiss. Wien, vol. 1, 1850, p. 378 , pl. 48 , fig. 10 .

Globulina amplectens Reuss, Zeitschr. deutsch. geol. Ges., vol. 3, 1851, p. 81, pl. 6 , fig. 44 .

Globulina inflata REuss, Zeitschr. deutsch Geol. Ges., vol. 3, 1851, p. 81, pl. 6, fig. 45 .

Globulina amygdaloides Reuss, Zeitschr. deutsch. Geol. Ges., vol. 3, 1851, p. 82 , pl. 6 , fig. 47.

Polymorphina amygdaloides Reuss, Sitz. Akad. Wiss. Wien, vol. 62, pt. 1, 1870, p. 486.- v. Schlicht, Foram. Septar. Pietzpuhl, 1870, pl. 27, figs. 7-9, 10-12. 
Guttulina diluta Bornemann, Zeitschr. deutsch. geol. Ges., vol. 12, 1860, p. 160, pl. 6, fig. $11 a, b, c$.

Polymorphina pauperata Terquem, Mém. Soc. Géol. France, sér. 3, vol. 1, 1878 , p. 38 , pl. 3 (8), figs. 11 a-19.

Globulina translucida D'Orbigny, Ann. Sci. Nat., vol. 7, 1826, p. 267, No. 25.-Terquem, Mém. Soc. Géol. France, sér. 3, vol. 2, 1882, p. 131, pl. 13 (21), fig. $31 a, b$.

Polymorphina translucida Fornasini, Mem. Accad. Sci. Istit. Bologna, ser. 5, vol. 10 , 1902 , p. 52 , fig. 51 .

Test ovate, more or less compressed, broadly rounded at the base, tapering toward the apex; chambers few, inflated, much overlapping, arranged in a nearly triserial series; sutures very slightly if at all depressed, distinct; wall smooth, translucent; aperture radiate.

Length, 0.50-0.85 mm.; breadth, 0.45-0.85 mm.; thickness, $0.25-$ $0.50 \mathrm{~mm}$.

As in the case of Globulina gibba, many different specific names are given to divergent forms of the globular, but compressed variety of Globulina, among which Globulina inaequalis Reuss has the priority. Globulina discreta Reuss reported in 1850 from the same locality as the present variety seems to us an abnormal form of the typical.

Reuss's several names given to the middle Oligocene compressed Globulinas are considered by the authors, after the examination of a great number of topotype specimens to be nothing but individual variations of one species, and they are placed with the Miocene Globulina inaequalis. Bornemann's Guttulina diluta has a rounded test and is not at all compressed. It might appear to be more reasonable to put it in Globulina gibba than in inaequalis, but we consider it an abnormal form of the present species, having the later chambers not fully developed.

Globulina translucida, named by d'Orbigny and illustrated much later by Terquem as well as by Fornasini, in its every respect is identical with the present species. Guttulina nitida d'Orbigny, figured by Fornasini, is doubtlessly related to the present one, as it has rather elongate chambers.

Distribution.-Our material includes the following localities:

Recent.-Mediterranean, shore sand, Rimini. Pacific, Australia, Torquay, on Bass Strait, Victoria. New Zealand, off Poor Knights Islands, 60 fathoms; off the Big King, 98 fathoms.

Pliocene.-United States, Santa Barbara, Calif. England, Crag, Sutton.

Miocene.-France, Helvetian, Moulin du Minoy, Salles; Aquitanian superieur, La Brêde, Larriey; St. Avit, near Mont de Marson; Burdigalien superieur, Pont Gourguet, Saucats; Burdigalien moyen, Le Coquillat, Leognan; St. Paul de Dax, Dax; Burdigalien inferieur, Moulin de l'Eglise, Saucats. Germany, Dingden, near Bochaft, Westphalia. Austria, Tortonian, Amphistegina marl, Grunes Kreuz, 
Nussdorf, Vienna; Voslau, Vienna. Hungary, Tortonian, Varpolata; Kostej, Banat; Lapugy. United States, Yellow River, Fla., threefourths mile east of Red Bay, Walton County, Fla.

Oligocene.-Germany, Ahnatal, near Cassel; Doberg near Bünde; Wiesloch, near Heidelberg; Lobsann; Flonheim, Mainz Basin; Hermsdorf, near Berlin; Cothen; Düsseldorf, Ratigen; Oeding. France, Stampien, Jeurs (Seine et Oise). United States, Byram marl, Byram, Miss.; southwest bank of Chickasawhay River, 500 feet west of bridge, $2 \frac{1}{2}$ miles south of Waynesboro, Miss.

Eocene.-France, Lutetien, Parens (Les Bôves); Lutetien, Grignon, Chaussy; Damery. England, Bracklesham bed XVII, White Cliff Bay, Isle of Wight; from Bracklesham material washed up on beach at Selsey; Thanetian, bed B, Pegwell Bay. Belgium, lower Eocene, Wansin. Germany, Hanover, upper Bavaria. Hungary, Neustift, Ofen. United States, Jacksonian, three-fourths mile below Robinson's Ferry, Sabine River, Sabine County, Tex., Cooper marl, pit on United States Highway No. 17, 1 mile south of Moncks Corner, Berkeley County, S. C.; Claibornian, Vincentown, N. J.; Midwayan, Tex.

\section{GLOBULINA INAEQUALIS Reuss var. CARIBAEA d'Orbigny}

Plate 18, figures 5,6

Globulina caribaea D'Orbigny, in de la Sagra., Hist. Fis. Pol. Nat. Cuba, vol. 6, 1840 , p. 130 , pl. 2 , figs. $7,8$.

Polymorphina leprosa Reuss, Sitz. Akad, Wiss. Wien, vol. 55, pt. 1, 1867, p. 89 , pl. 4 , fig. 3 .

Polymorphina horrida KARRer, Abhandl. k. k. geol. Reichsanst, vol. 9, 1877 , p. 385 , pl. $16 b$, fig. 46.

Polymorphina asperella KARRer, Abhandl. k. k. geol. Reichsanst, vol. 9, 1877 , p. 385 , pl. $16 b$, fig. 47.

Globulina hispida Terquem, Mém. Soc. Géol. France, sér. 3, vol. 2, 1882, p. 131, pl. 13 (21), fig. 32 .

Polymorphina spinosa Sideвoтtom, Mem. Proc. Manchester Lit. Philos. Soc., vol. 51, no. 9, 1907, p. 15, pl. 3, figs. 10, 11 .

Polymorphina lactea Cushman, Carnegie Instit. Washington, Publ. No. 311, 1922, p. 34, pl. 4, figs. 10, 11.

Variety differing from the typical, the wall ornamented, wholly or partly, with fine short spines.

Length $0.45-0.50 \mathrm{~mm}$; ; breadth $0.38-0.40 \mathrm{~mm}$; thickness $0.22-0.25$ $\mathrm{mm}$.

D'Orbigny's original specimen is lost. We have studied the material dredged from off $\mathrm{Cuba}$ and adjacent areas, and obtained several specimens close to Globulina caribaea, but in which the spiny ornamentation covers the entire surface and the sutures are not as much depressed as shown in the figure of Globulina caribaea as well as described by d'Orbigny. But the surface ornamentation of any species of the Polymorphinidae is subject to variation; therefore we have placed our specimens under d'Orbigny's species. 
Polymorphina rugosa, described in the same paper by d'Orbigny, has an abnormally enlarged but compressed last chamber. Although treated by d'Orbigny as a distinct species from Globulina caribaea, we consider it better to include it in that species.

There are many other names given to ornamented, compressed forms of Globulina by various authors, of which Polymorphina leprosa Reuss, recorded from the Miocene (Salzthone) in Galicia, is a form with more or less depressed sutures and the surface marked with roughly scattered spines.

Polymorphina asperella Karrer and Globulina hispida Terquem are characterized by fine spines uniformly distributed, while in Polymorphina horrida Karrer, having one extra chamber, the spines are much stouter, giving the rough appearance to the surface.

Globulina caribaea is often found attached to shells by its flattened surface.

Distribution.-Often found in various Tertiary deposits, as well as in Recent shallow-water dredgings. Our specimens were obtained from the following localities:

Recent.-Atlantic, numerous stations off the Dry Tortugas, Fla., 10-18 fathoms; beach sand, Newport, R. I.; Albatross D2112, 15.5 fathoms, and D2262, 250 fathoms, east coast of United States.

Miocene.-France, Burdigalien moyen, Le Coquillat, Leognan; Burdigalien inferieur, Moulin de l'Eglise, Saucats.

Oligocene.-Germany, Ahnatal, near Cassel.

Eocene.-France, Lutetien, Parnes (Les Bôves); Lutetien, Grignon; Courtagnon; Damery.

GLOBULINA INAEQUALIS Reuss var. DOLLFUSSI Cushman and Ozawa, new variety

Plate 18, figure 7

Variety differing from the typical form in its attached state.

Holotype: Length, $0.55 \mathrm{~mm}$; breadth, $0.47 \mathrm{~mm}$; thickness, 0.27 $\mathrm{mm}$.

Holotype of variety.-(Cushman Coll.No.11547.) From the Miocene, lower Burdigalien, Le Coquillat, Leognan, near Bordeaux, France.

This variety is named for Professor Dollfuss of Paris.

GLOBULINA INAEQUALIS Reuss var. SPINATA Cushman and Ozawa, new variety

Plate 17, figures $1 a, b$

Variety differing from the typical in its attached state and spiny surface.

Holotype: Length, $0.30 \mathrm{~mm}$; breadth, $0.25 \mathrm{~mm}$; thickness, 0.16 $\mathrm{mm}$

Holotype of variety. - (Cushman Coll. No.11546.) Found in the upper Oligocene at Cassel, Ahnatal, Germany. 


\section{GLOBULINA LACRIMA Reuss}

Plate 19, figures 1, 2

Polymorphina (Globulina) lacrima Reuss, Die Verstein. böhm. Kreide., 1845 , p. 40 , pl. 12 , fig. 6 ; pl. 13, fig. 83.-EGGER, Abhandl. kön. bay. Akad. Wiss. München, Cl. II, vol. 21, pt. 1, 1899, p. 125, pl. 17, figs. 39,40 .

Globulina lacrima Reuss, Haidinger's Nat. Abhandl., vol 4, 1851, p. 27, pl. 4, fig. 9 .

Globulina lacrynia ALth, Haidinger's Nat. Abhandl., vol. 3, 1850, p. 263, pl. 13, fig. 16.

Polymorphina gibba Chapman (not d'Orbigny), Journ. Roy. Micr. Soc., 1896, p. 9, pl. 2, fig. 5.-EGGer, Abhandl. kön. bay. Akad. Wiss. München, Cl. II, vol. 21, pt. 1, 1899, p. 128, pl. 17, figs. 19, 20.-Franke, Abhandl. geol. pal. Instit. Univ. Greifswald, vol. 6, 1925, p. 76, pl. 6, fig. $15 a, b$.Cushman, Bull. Amer. Assoc. Petr. Geol., vol. 10, 1926, p. 604, pl. 20, figs. 8, 15.-Franke, Danmarks Geol. Unders. II, Raekke, No. 46, 1927, p. 32 , pl. 3 , fig. 9 .

Polymorphina longicollis KARRER, Jahrb. k. k. geol. Reichsanstalt, vol. 20, 1870 , p. 181, pl. 2, fig. 11.

Polymorphina gutta Chapman (not d'Orbigny), Journ. Roy. Micr. Soc., 1896, p. 10, pl. 2, fig. 7.-Franke (not d'Orbigny), Danmarks Geol. Unders. II, Raekke, No. 46, 1927, p. 33, pl. 3, fig. 11.

Polymorphina laclea EGGER (not Walker and Jacob), Ber. nat. Ver. Passau, 1907, p. 40 , pl. 4 , fig. 24.

Test subglobular, the base broadly rounded, apertural end produced and regularly acuminate, the sides straight and not concave, typically rounded in end view; chambers few, extending back almost to the base; sutures not depressed; wall smooth; aperture radiate, slightly produced.

Length, $0.55-0.75 \mathrm{~mm}$.; breadth, 0.40-0.55 mm.; thickness, $0.40-$ $0.55 \mathrm{~mm}$.

We do not deny that the Cretaceous Globulina lacrima is very close to and almost identical with Tertiary and Recent Globulina gibba. If, however, we should examine Globulina lacrima, or Cretaceous Globulina gibba identified by other authors, we would be surprised to find all specimens constant in their characters. The apertural end is definitely produced. The Cretaceous specimens of both Europe and America that we have examined are constant in this character. Among Tertiary and Recent Globulina gibba there are some which have a produced aperture as in Globulina gibba var. pyrula Egger, but in this case the side is always concave instead of straight as in $G$. lacrima. Polymorphina longicollis Karrer is described as having a compressed test, and may be distinct from the present species. Polymorphina ovulata Dunikowski, judging from the figure, appears to be a young stage of Marginulina; but if it be Globulina, it would be related to Globulina lacrima.

Distribution.-The geological range seems to be limited. We have specimens from the Cretaceous, both of America and Europe. The localities are: England, chalk marl, Folkestone; Saxon Cement 
Works, Cambridge. France, chalk, Bougival. Germany, Galling, near Siegsdorf, Upper Bavaria; Dasbeck, Stemmerberg, and Rinkerode, Westphalia; Merkinghaven, near Henrichburg, Westphalia. Trinidad, Lizard Spring. Mexico, Velasco shale, Hacienda El Limon, Vera Cruz. United States, Navarro formation, clay pit, 3 miles south of Corsicana, Tex.

GLOBULINA LACRIMA Reuss var. SUBSPHAERICA (Berthelin)

Plate 19 , figures $5-7$

Polymorphina subsphaerica Berthelin, Mém. Soc. Géol. France, sér. 3, vol. 1,1880 , p. 58, pl. 4 , fig. $18 a, b$.

Polymorphina gibba Jones and Chapman (not d'Orbigny), Journ. Linn. Soc. Zool., vol. 25,1896 , p. 509, fig. 5 (in text).

Variety differing from the typical in the slightly compressed test, which is more rounded at the base than at the apertural end.

Length $0.33-0.45 \mathrm{~mm}$; breadth $0.30-0.40 \mathrm{~mm}$; thickness 0.20 $0.30 \mathrm{~mm}$.

This variety of the Cretaceous is a slightly compressed Globulina lacrima with a rounded base. Somewhat similar forms can be found among the Tertiary and Recent Globulina gibba, but like the typical form of Globulina lacrima, the variety keeps its definite character, so far as we have examined specimens from the Cretaceous, both of Europe and America.

Distribution.-We have specimens representing the following Cretaceous localities: England, lower Gault, Barnwell pit, Cambridge; brickyard, Cambridge. Germany, Stemmerberg, Westphalia; Galling, near Siegsdorf, Upper Bavaria; Turonian, HinterFessen, near Pirna. United States, Navarro formation, clay pit, 3 miles south of Corsicana, Tex.; core at Mexia, 248-455'. Ripley formation, $3 \frac{1}{2}$ miles northeast of Ripley Bluff, on Owl Creek, Miss. Mexico, Velasco shale, Hacienda El Limon, Vera Cruz.

GLOBULINA LACRIMA Reuss var. ERICIA Cushman and Ozawa, new variety

\section{Plate 19, figure 4}

Polymorphina gutta Jones and Chapman, Journ. Linn. Soc. Zool., vol. 25, 1896, p. 513, fig. 29 (in text).-Chapman, Journ. Roy. Micr. Soc., 1896 , p. 10 , pl. 2 , fig. 8 .

Variety differing from the typical in the ornamentation of the test, consisting of scattered, stout, blunt spines, often unequally distributed.

Holotype: Length, including spines, $0.65 \mathrm{~mm}$; breadth $0.40 \mathrm{~mm}$. Holotype of vuriety.-(Cushman Coll. No. 11574.) From the chalk marl of Saxon Cement Works, Cambridge England. Paratype in collection of Geological Institute, Imperial University of Tokyo, Japan. 
The variety can be compared with Globulina gibba d'Orbigny var. tuberculata d'Orbigny in its stout spiny ornamentation, but the form of the test and the tapering apertural end will distinguish the two.

GLOBULINA LACRIMA Reuss var. HORRIDA Reuss

Plate 19, figure 3

Globulina horrida Reuss, Verstein. Böhm. Kreide, pt. 2, 1845-46 (1846), p. 110 , pl. 43, fig. 14; Haidinger's Nat. Abhandl., vol. 4, 1851, p. 27, pl. 4, fig. 8.-Jones and Chapman, Journ. Linn. Soc. Zool., vol. 25, 1896 , p. 510, fig. 10 (in text); p. 511, fig. 16 (in text).

Polymorphina horrida EgGer, Abhandl. kön. bay. Akad. Wiss. München, Cl. II, vol. 21 , pt. 1,1899 , p. 130, pl. 17 , fig. 16 .

Aulostomella pediculus Alth, Haidinger's Nat. Abhandl., vol. 3, 1850, p. 264, pl. 13, fig. 17.

Polymorphina orbignii Weller (not Zborzewski), Geol. Surv. New Jersey, Paleontology, vol. 4, 1907, p. 252, pl. 3, fig. 26.

Variety differing from the typical in having the surface finely spinose and usually the apertural end fistulose.

Length $0.40-0.75 \mathrm{~mm}$; breadth $0.22-0.30 \mathrm{~mm}$; thickness 0.20 $0.30 \mathrm{~mm}$.

This variety occurs with the typical form in the Cretaceous of Europe and America and is to be distinguished from the typical form mainly by the two characters, the ornamentation of the surface and the peculiar arrangement of the fistulose outgrowths which are somewhat regularly stellate.

Distribution.-We have specimens from the following Cretaceous localities: Germany, Galling, near Siegsdorf, Upper Bavaria. England, Cambridge greensand, Saxon Cement Works, Cambridge. United States, Navarro formation, clay pit 3 miles south of Corsicana, Tex.

\section{GLOBULINA AMPULLA (Jones)}

Plate 19, figures $9 a-c$

Polymorphina ampulla Jones, Quart. Journ. Geol. Soc., vol. 8, 1852, p. 267, pl. 16, fig. 14.

Polymorphina gibba D'Orbigny var. ampulla Burrows and Holland, Proc. Geol. Assoc., vol. 15, 1897, p. 45, pl. 2, fig. 14.

Guttulina nitida D'Orbigny, Ann. Sci. Nat., vol. 7, 1826, p. 266, No. 17.Fornasini, Mem. Accad. Sci. Istit. Bologna, ser. 5, vol. 9, 1901, p. 70, fig. 22.

Polymorphina lactea Chapman (not Walker and Jacob), Journ. Roy. Micr. Soc., 1896, p. 9, pl. 2, fig. 3.

Polymorphina lactea Plummer (not Walker and Jacob), Bull. 2644, Univ. Texas, 1927, p. 121, pl. 6, figs. $7 a-c$.

Test oval, pointed at both ends, unequally convex; chambers few, each slightly farther from the base as added; sutures very slightly 
depressed, distinct; wall smooth, thin, almost transparent, initial end sometimes with spines; aperture very finely radiate, produced.

Length $0.40-0.75 \mathrm{~mm}$; breadth $0.30-0.60 \mathrm{~mm}$; thickness 0.25 $0.50 \mathrm{~mm}$.

Globulina ampulla has been neglected by later authors probably because of its resemblance to Globulina gibba. It is different from the latter in its pointed end, often with a spine and slightly depressed sutures which are stronger at the base.

Distribution.-Jones described this form from the lower Eocene, Thanetian beds of Pegwell Bay, England. We have specimens from the Eocene of France from the Lutetien of Parnes (Les Bôves) and Vaudancourt. A specimen from the Burdigalien inferieur of Moulin de l'Eglise, Saucats, France, is also referred here with some question.

GLOBULINA EXSERTA (Berthelin)

Plate 20, figures $2 a-c$

Polymorphina exserta Berthelin, Mém. Soc. Géol. France, sér. 3, vol. 1, 1880 , p. 57, pl. 4 , figs. $22 a-23 b$.

Polymorphina bucculenta Berthelin, Mém. Soc. Géol. France, sér. 3, vol. 1, 1880 , p. 58 , pl. 4 , figs. $16 a-17 b$.

Test more or less compressed, oval to ovate, initial end often produced; chambers inflated, earlier ones small, later ones much larger, not much embracing, arranged in a nearly triserial series; sutures but little depressed, distinct; wall smooth; aperture radiate.

Length $0.55-0.60 \mathrm{~mm}$.; breadth $0.30-0.35 \mathrm{~mm}$; thickness $0.23-$ $0.27 \mathrm{~mm}$.

Berthelin described two species of Polymorphina: P. exserta, and $P$. bucculenta which appear to be closely related to each other. They have the early chambers relatively small, the last two large, and show no great difference in important characters. $P$. bucculenta is rather unsymmetrical compared with the other, because the last chamber does not extend down to the base. $P$. exserta has a produced initial chamber. Such differences are not important as shown by Berthelin's figures of two individuals of $P$. bucculenta which he considered to be individual variation.

We have many specimens of the present species from both European and North American Cretaceous, and we are convinced that the species is variable in the range shown by Berthelin's figures of the above cited species.

Distribution.-P. exserta is apparently limited to the Cretaceous and is very common in the Lower Cretaceous. The localities of our specimens are: Cretaceous, England, chalk marl, Saxon Cement Works, Cambridge; Cambridge greensand, same locality. United States, Goodland formation, near Fort Worth, Tex. 
GLOBULINA FLEXA Cushman and Ozawa, new species

Plate 20, figures $1 a-c$

Test longer than broad, greatest width above the middle, sides not equally convex, base broad but tending to become pointed at the middle, round in transverse section; chambers few, extending well toward the base; sutures distinct, doubly curved in a sigmoid manner, the upper part convex, the basal portion concave; wall smooth, translucent; aperture radiate, somewhat extended.

Length $0.60-0.70 \mathrm{~mm}$; breadth $0.32-0.37 \mathrm{~mm}$; thickness $0.25-$ $0.30 \mathrm{~mm}$.

Holotype-(Cushman Coll. No. 11,587.) From upper Oligecene, Doberg, near Bünde, Germany.

The elongate test and the doubly curved sutures in a sigmoid manner are very characteristic of the species, and there is little danger of confusing Globulina flexa with any other species or varieties of Globulina. The nearest species is Globulina ampulla, having a broadly rounded base pointed at the middle as in the present species, but Globulina flexa has a longer test with sigmoid, curved sutures.

Soldani's Polymorphium pyriformium, compared by d'Orbigny with his Pyrulina gutta, has an elongate test, and its sutures are curved in a sigmoidal manner and is probably identical with the present species.

Distribution.-We have specimens of this striking and beautiful foraminifer from the upper Oligocene of Ahnatal, near Cassel, Germany. A very similar form occurs in Recent material from Dogs Bay, Ireland.

\section{GLOBULiNA GRANULOSA Egger}

Plate 20, figures 5,7

Polymorphina (Globulina) granulosa EgGer, Neues Jahrb. für Min., Jahrg. 1857, p. 290, pl. 14, figs. 1, 2.

Polymorphina granulosa H. B. Brady, Parker, and Jones, Trans. Linn. Soc., vol. 27,1870 , p. 238 , pl. 41 , figs. $26 a, b$.

Globulina graieloupi D'OrBigny, Ann. Sci. Nat., vol. 7, 1826, p. 267, No. 23. Polymorphina (Globulina) grateloupi Fornasini, Riv. Ital. Pal., vol. 8, 1902, p. 2 , pl. 1, fig. 6 .

Globulina elongata D'Orbigny, Ann. Sci. Nat., vol. 7, 1826, p. 267, No. 24.

Polymorphina (Globulina) elongata Fonnasini, Riv. Ital. Pal., vol. 8, 1902, p. 2 , pl. 1 , fig. 7 .

Test oval, rounded at the initial end, more or less acute toward the aperture, nearly circular in end view; chambers few, arranged in an almost triserial series, the last-formed one generally much removed from the base; sutures not depressed, often indistinct; wall fairly thick, ornamented by numerous fine longitudinal costae not greatly raised, independent of the sutures and close together; aperture broad, radiate, slightly produced.

Length, $0.50-0.65 \mathrm{~mm}$; breadth, $0.30-0.42 \mathrm{~mm}$; thickness, $0.30-$ $0.40 \mathrm{~mm}$. 
Polymorphina granulosa Egger seems to be closer to Globulina striata in general features, especially in its shape, but the paratype specimen of the latter examined by us is an ornamented Globulina gibba, and the test is not elongated as in Polymorphina granulosa.

D'Orbigny's Globulina grateloupi and Globulina elongata, both from Dax and figured by Fornasini, coincide in their general features with the present species; the differences are the more acuminate apertural end and slightly compressed test. We have examined a large number of specimens from Dax and Bordeaux which are referable to Globulina grateloupi or G. elongata, and found that most specimens are closer to Egger's Globulina granulosa.

Globulina granulosa is distinguished from other related Globulinas by its elongate test.

Distribution.-The species is rather common in European younger Tertiary deposits. Our specimens represent the following localities:

Miocene.-France, Burdigalien superieur, Pont Pourguet, Saucats; Burdigalien moyen, Le Coquillat, Leognan; St. Paul de Dax, Dax; Burdigalien inferieur, Moulin de d'Eglise, Saucats. Germany, Ortenberg.

\section{GLOBUliNA GRANULOSA Egger var. POLITA (Terquem)}

Plate 21, figures $1 a-c$

Polymorphina polita Terquem, Mém. Soc. Géol. France, sér. 3, vol. 2, 1882, p. 139, pl. 14 (22), figs. 23-25.-H. B. Brady, PARKer, and Jones, Trans. Zool. Soc., vol. 12, 1888, p. 224, pl. 44, fig. 11.

Guttulina laevigata D'OrBigny, Ann. Sci. Nat., vol. 7, 1826, p. 266, No. 19.Fornasini, Mem. R. Accad. Sci. Istit. Bologna, ser. 6, vol. 5, 1908, p. 43 , pl. 1, figs. $10,10 a, 10 b$.

Polymorphina pupa D'Orbigny, Ann. Sci. Nat., vol. 7, 1826, p. 265, No. 9.Fornasini, Riv. Ital. Pal., vol. 8, 1902, p. 2, pl. 7, fig. 3.

Variety differing from the typical in its surface, which is smooth.

Among the figures of Polymorphina polita Terquem from the Eocene of Vaudancourt, at least figure 25 can be included in the present variety. His figure 24 shows a specimen having the last chamber much farther removed from the base and the Figure 23 having the chamber still more removed. We place them under this variety with some doubts. Polymorphina obscura d'Orbigny, figured by Terquem, resembles figure 23 of Polymorphina polita, the difference being only in the compressed test. D'Orbigny's Guttulina laevigata, figured by Fornasini, is probably a shorter form of the present variety.

Length, $0.40-0.80 \mathrm{~mm}$.; breadth, $0.23-0.55 \mathrm{~mm}$.; thickness, $0.20-$ $0.50 \mathrm{~mm}$.

Distribution.-We have specimens from the following localities:

Pliocene.-England, Crag of Sutton (?). Italy, Castel Arquato.

Miocene.-France, Aquitanian superieur, St. Avit, near Mont de Marsan; Burdigalien moyen, Le Coquillat, Leognan; Burdigalien 
inferieur, Moulin de l'Eglise, Saucats. Austria, Tortonian, Streibersdorf; Voslau, near Baden, Vienna Basin.

Oligocene.--Upper, Germany, Ahnatal, near Cassel. Lower, Latt$\operatorname{dorf}(?)$.

Eocene.-Italy, Bartonian, Val di Lonte (?).

\section{GLOBULINA MINUTA (Roemer)}

Plate 20, figures 3,4

Polymorphina minuid Roemer, Neues Jahrb. f. Min., etc., 1838, p. 386, pl. 3, fig. 35.-Reuss. Sitz. Akad. Wiss. Wien, vol. 62, pt. 1, 1870, p. 486.v. Schlicht, Foram. Septar. Pietzpuhl, 1870, pl. 27, figs. 13-15; pl. 25, figs. 51-56.-Bornemann, Zeitschr. deutsch. geol. Gesell., vol. 7, 1855, p. 344 , pl. 17 , fig. 3 .

Polymorphina (Guttulina) aff. minima Andreat, Abhandl. Geol. SpecialKarte Elsass-Lothringen, vol. 2, pt. 3, 1884, p. 118, pl. 9, fig. 16.

Polymorphina similis Reuss, Sitz. Akad. Wiss. Wien, vol. 18, 1855 (1856), p. 249 , pl. 7 , fig. 79 .

Polymorphina sororia Reuss, Sitz. Akad. Wiss. Wien, vol. 48, pt. 1, 1863, p. 57, pl. 7, figs. 72 (?), 73, 74; Bull. Acad. Roy. Sci. Belg., ser. 2, vol. 15, 1863 , p. 151 , pl. 2 , fig. 25 (not 26-29).

Polymorphina gracilis Reuss, Sitz. Akad. Wiss. Wien, vol. 62, pt. 1, 1870, p. 486.-v. Schlicht, Foram. Septar. Pietzpuhl, 1870, pl. 31, figs. 34-37, $42,45-49$; pl. 32 , figs. 5-16, 27, 28.

Polymorphina acuta Reuss, Sitz. Akad. Wiss. Wien, vol. 62, pt. 1, 1870, p. 486.-v. Schlicht, Foram. Septar. Pietzpuhl, 1870, pl. 27, figs. 19-21; pl. 29 , figs. $15,16,43-46$.

Polymorphina lactea Burrows, Sherborn, and BaIley (not Walker and Jacob), Journ. Roy. Micr. Soc., 1890, p. 561, pl. 11, figs. 9, 10.-EGger, Abhandl. kön. bay. Akad. Wiss., München, Cl. II, vol. 18, 1893, p. 308, pl. 9, figs. 8, 14, 15.-Mills, Trans. Hull. Sci. \& Field Nat. Club, vol. 1,1900 , p. 149 , pl. 11, fig. 33 .

Polymorphina lactea elongate variety, Weller, Geol. Surv. New Jersey, Paleontology, vol. 4, 1907, p. 251, pl. 3, figs. 24-25.

Test fusiform, pointed at both ends, circular to elliptical in section; chambers few, elongate, each some distance from the base; sutures distinct, not depressed; wall smooth; aperture radiate, pointed.

Length $0.50-0.70 \mathrm{~mm}$.; breadth $0.20-0.35 \mathrm{~mm}$.; thickness $0.20-0.35$ $\mathrm{mm}$.

This is an elongate, fusiform Globulina, having the chambers arranged as in Globulina gibba. Globulina similis, described as having seven chambers, may represent the microspheric form of the present species. It has a slightly compressed test and is placed as intermediate between Bornemann's Globulina minima and Roemer's Globulina minuta. The latter two forms may be considered to represent both extremes in the degree of the compression of the test. Among Polymorphina gracilis Reuss, which name is given to Schlicht's figures, there are some which can be included in Globulina minuta. They are the figures $5-8$ and 27,28 in Plate 32. 
Very distinct characters are lacking to make this a well-defined species. Early stages of other Polymorphinidae are often very similar to this and may be confused with it.

Distribution.--Our specimens, some of them referred very questionably to this species, are from the following localities:

Recent.-Tripoli.

Pliocene.-Fiji.

Miocene.-Hungary, Lapugy.

Oligocene.-Germany, Düsseldorf; Söllingen; Oeding.

Eocene.-France, Lutetien, Grignon; Chaussy. Italy, Bartonian, Val di Lonte. Belgium, Wansin. United States, Jacksonian, east bank of Sepulga River, 6 $\frac{1}{2}$ miles north of Brooklyn, Conecuh County, Ala. Trinidad, Cipero section.

\section{GLOBULINA GRAVIS (Karrer)}

Plate 21, figures $2 a-c$

Polymorphina gravis KARReR, Jahrb. k. k. geol. Reichsanstalt, vol. 20, 1870, p. 181, pl. 2, fig. 12 .

Test ovate, rounded at the base, acute at the apertural end; chambers inflated, oval, arranged in a nearly triserial series; sutures slightly depressed, distinct; wall smooth; aperture radiate.

Figured specimen length $1.10 \mathrm{~mm}$.; breadth $0.60 \mathrm{~mm}$; thickness $0.50 \mathrm{~mm}$.

Globulina gravis, in its general features, resembles Globulina rotundata, but it has more elongated chambers, and the test is very acute toward the apertural end. It is evidently related to Globulina lacrima, while Globulina rotundata is derived from Globulina gibba.

Distribution.-Globulina gravis is limited to the Cretaceous. We have specimens from Maastricht, Holland, and from the Cambridge greensand, Saxon Cement Works, Cambridge, England.

\section{GLOBULINA AMPLA (Karrer)}

Plate 21, figure 5

Polymorphina ampla KARRer, Jahrb. k. k. geol. Reichsanstalt, vol. 20, 1870, p. 181, pl. 2, fig. 13 .

Test oval, somewhat rounded at both ends; chambers few, slightly longer than wide, embracing, arranged in a nearly triserial series; each succeeding chamber more or less removed from the base; sutures not depressed, distinct; wall smooth; aperture radiate.

Figured specimen, length $0.60 \mathrm{~mm}$.; breadth $0.50 \mathrm{~mm}$.; thickness $0.40 \mathrm{~mm}$.

The present species is described as having a coarse test which would probably be affected by fossilization. Our specimen obtained from the uppermost Cretaceous at Maastricht is very similar to Karrer's species in general features, but the wall is smooth. It may represent 
a Cretaceous form corresponding to Tertiary Globulina rotundata, which has almost the same features.

\section{GLOBULINA CONSOBRINA (Fornasini)}

Plate 21, figures $6 a-c$

Polymorphina sororia Reuss var. consobrina Fonnasini, Mem. Istit. Bologna Accad. Sci., ser. 5, vol. 18, 1900-1902, p. 69, fig. 21 (in text).

Test typically fusiform, pointed at both extremities; chambers rounded, arranged in an almost triserial series; sutures depressed but little, distinct; wall smooth; aperture radiate.

Length $0.60-1.25 \mathrm{~mm}$; breadth $0.45-0.90 \mathrm{~mm}$; thickness $0.30-$ $0.60 \mathrm{~mm}$.

Globulina consobrina is closely related to Clobulina rotundata, but its initial end is acuminate.

Distribution.-Rather common in European young Tertiary deposits. Fornasini's figured specimen was obtained from the Pliocene of Siena. We have specimens from the following localities:

Miocene.-Hungary, Tortonian, Varpolata. Austria, Tortonian, Amphistegina marl, Grunes Kreuz, Nussdorf, Vienna. France. St. Avit, near Mont de Marsan, Helvetian, Moulin de Minoy, Salles; Burdigalien inferieur, Moulin de l'Eglise, Saucats.

\section{GLOBULINA MÜNSTERI (Reuss)}

Plate 22, figures $3 a-c$

Polymorphina münsteri Reuss, Sitz. Akad. Wiss. Wien, vol. 18, 1855 (1856), p. 249 , pl.. 8 , fig. 80 .

Polymorphina ovulum Reuss, Sitz. Akad. Wiss. Wien, vol. 18, 1855 (1856), p. 250 , pl. 8 , fig. 83 .

Polymorphina amygdaloides Reuss, Sitz. Akad. Wiss. Wien, vol. 18, 1855 (1856), p. 250, pl. 8, fig. 84.-Burrows and Holland, Proc. Geol. Assoc., vol. 15, 1897, p. 46, pl. 2, fig. 18.

Polymorphina communis D'ORBIGNy var. etrusca Fornasini, Mem. Accad. Sci. Istit. Bologna, ser. 5, vol. 9, 1900-1902, p. 70, fig. 23 (in text).

Polymorphina obtusa D'Orbigny, Ann. Sci. Nat., vol. 7, 1826, p. 265, No. 1.Fornasini, Boll. Soc. Geol. Ital., vol. 19, 1900, p. 146, fig. 4 (in text).

Polymorphina gibba Burrows, Sherborn, and Bailey, Journ. Roy. Micr. Soc., 1890 , p. 561, pl. 11, fig. 13.

Test ovate to oval, more or less compressed, rounded at the base; chambers rather elongated, embracing, arranged in a nearly overlapping, triserial series; sutures not depressed, generally distinct; wall smooth, often with fistulose tubes; aperture radiate.

Length $0.45-0.70 \mathrm{~mm}$; breadth $0.25-0.50 \mathrm{~mm}$; thickness $0.18-0.38$ $\mathrm{mm}$.

In 1856 Reuss described three species of compressed and o al Globulina from the German Oligocene. They are Polymorphina münsteri, $P$. amygdaloides, and $P$. ovulum, of which the second is the 
most compressed, but does not show any difference in its arrangement of chambers from the first. Of the last species, two different specimens are figured from the same side, and the figures show no important difference from the other two species.

Polymorphina communis var. etrusca Fornasini has an ovate test with broadly rounded base, but the arrangement of its chambers and the compressed test are the same as those of the present species, and it can be safely put in the synonymy.

Polymorphina obtusa d'Orbigny, figured by Fornasini, has almost the same appearance as Fornasini's Polymorphina etrusca, and we have no reason to separate them. On the other hand, d'Orbigny's species figured by Terquem is from the figure a 4-chambered specimen, having rather rounded chambers arranged in an alternating almost uniserial series. It seems to be quite distinct from the specimen figured by Fornasini. According to Terquem's description, his Polymorphina obtusa has a compressed test. In this point it differs from Pyrulina. It is impossible for us to place his species in any known species.

Distribution.-Our material ranges from Miocene to Upper Eocene as follows:

Miocene.-France, Helvetian, Pontlevoy. Hungary, Tortonian, Varpolata. Austria, Tortonian, Amphistegina marl, Grunes Kreuz, Nussdorf, Vienna. Germany, Ortenburg.

Oligocene.--Germany, Ahnatal, near Cassel. Mexico, TampicoPanuco Railroad, kilometer post 20.9, Vera Cruz; near Cuesta Blanca, Zacamixtle, Vera Cruz.

Eocene-France, Bartonian, Le Guepelle (Seine et Oise). United States, Alabama, Jacksonian, road from Perdue Hill to Claiborne, Munroe County; on small stream entering Conecuh River, 1 mile east of Beck, Covington County; east bank Sepulga River, 31/2 miles northeast of Brooklyn, Conecuh County, Ga., on old Waynesboro Road, 5 miles north of Millen, Jenkins County.

\section{GLOBULINA ROTUNDATA (Bornemann)}

Plate 21, figures 3,4

Guttulina rotundaia Bornemann, Zeitschr. deutsch. geol. Gesell., vol. 7, 1855 , p. 346 , pl. 18 , fig. 3 .

Polymorphina rotundata H. B. Brady, PARKer, and Jones, Trans. Linn. Soc., vol. 27, 1870, p. 234, pl. 40, figs. $19 a-e$; Woodcuts $k, l, m$.-H. B. Brady, Ann. Mag. Nat. Hist., ser. 5, vol. 1, 1878, p. 435, pl. 20, figs. $6 a, b$.-Sideвоттом, Mem. Proc. Manchester Lit. Philos. Soc., vol. 151, No. 9, 1907, p. 11, pl. 2, fig. 18.

Guttulina fracta Bornemann, Zeitschr. deutsch. geol. Gesell., vol. 7, 1855, p. 344 , pl. 17 , fig. 4 .

Guttulina incurva Bornemann, Zeitschr. deutsch. geol. Gesell., vol. 7, 1855, p. 345 , pl. 17 , fig. 6 . 
Guttulina globosa Bornemann, Zeitschr. deutsch. geol. Gesell., vol. 7, 1855, p. 346 , pl. 18 , fig. 1 .

Guttulina obtusa Bornemann, Zeitschr. deutsch. geol. Gesell., vol. 7, 1855, p. 346 , pl. 18 , fig. 2 .

Guttulina turgida Reuss, Sitz. Akad. Wiss. Wien, vol. 18, 1855 (1856), p. 246 , pl. 6 , fig. 66 .

Polymorphina turgida Reuss, Sitz. Akad. Wiss. Wien, vol. 62, pt. 1, 1870, p. 487.-v. Sснцicht, Foram. Septar. Pietzpuhl, 1870, pl. 28, figs. 6-10; pl. 29 , figs. $1-5$.

Globulina subalpina Gümbes, Abhandl. kön. bay. Akad. Wiss. München, Cl. II, vol. 10,1870 , p. 646 , pl. 2 , fig. $80 a, b$.

Polymorphina subcruciata Terquem, Mém. Soc. Géol. France, sér. 3, vol. 2, 1882 , p. 140 , pl. 14 (22), figs. $26,27$.

Test ellipsoidal or ovoid to cylindrical, rounded at the base, slightly produced at the apertural end; chambers rounded, almost as long as broad, arranged in a nearly triserial series, each succeeding chamber removed much farther from the base, rarely becoming almost uniserial in the last chamber; sutures but little depressed, generally distinct; wall smooth, thick, often with fistulose tubes; aperture radiate.

Length $0.45-0.90 \mathrm{~mm}$; ; breadth $0.30-0.60 \mathrm{~mm}$.; thickness $0.25-0.55$ $\mathrm{mm}$.

In their monograph of the genus Polymorphina, H. B. Brady, Parker, and Jones united many compact, oval species of the Polymorphinidae described by Bornemann in 1855 from the Septaria clay of Hermsdorf under the name Polymorphina roiundata. This was selected by them because it represented the best-developed specimen in spite of the earliest name among their synonyms, which is Guitulina fracta.

The present species is almost circular in section; therefore its figures show more or less differences according to the position of the specimen drawn. For example, Bornemann's Guttulina obtusa, judging from his figures, has almost the same cylindrical test as his $G$. rotundata, but in its sutures appears to be quite different from the latter. Bornemann's Guitulina globosa (1855), although it has the test more inflated at the base, presents the same feature of the sutures as his Guttulina obiusa, so far as shown by the figures. The difference of shape can be considered to be within the range of usual variation. Terquem's Polymorphina subcruciata and d'Orbigny's Polymorphina pupa, figured by Fornasini, are also related to the present group.

Reuss's Guttulina turgida from the Oligocene of Luithorst has the later chambers each much farther removed from the base as in Globulina rotundata, though it has almost an oval test.

The present species as above described has a tendency to add the later chambers in a more or less uniserial series, as is shown in Bornemann's Guttulina fracta and G. incurva, of which the latter appears to 
be an abnormal form, because its last chamber is added on the same side as the former one. Such an abnormality often occurs in the Polymorphinidae.

Distribution.-Fairly common in the various European Tertiary deposits, although it occurs in other continents and as a Recent species.

Recent.-Tripoli.

Pliocene.-England, Crag of Sutton.

Miocene.-France, Helvetian, Pontlevoy; Moulin de Minoy, Salles; Aquitanian superieur, St. Avit, near Mont de Marson; Burdigalien superieur, Merignac; Burdigalien moyen, Le Coquillat, Leognan. Hungary, Tortonian, Varpolata (very abundant); Lapugy. Austria, Perchtoldsdorf, near Vienna. United States, Choctawhatchee formation, 1 mile east of Red Bay, Walton County, Fla.

Oligocene.-Germany, Ahnatal, near Cassel; Hermsdorf, near Berlin; Hildesheimer Wald, Dickholzen; Doberg, near Bünde.

Eocene.-England, Bracklesham bed XVIII, White Cliff Bay, Isle of Wight; Thanetian, Pegwell Bay. France, Lutetien, Grignon. Belgium, lower Eocene, Wansin. United States, Cooper marl, dump heap from Charleston Aqueduct tunnel, 1 mile west of Givhans, Dorchester County, S. C.; pit on United States Highway No. 17, threefourths mile west of Moncks Corner, Berkeley County, S. C.

GLOBULINA ROTUNDATA (Bornemann) var. PYRULA (Fornasini)

Plate 15, figures $5 a-c$

Polymorphina rotundata Bonnemann var. pyrula Fonnasini, Mem. Istit. Bologna Accad. Sci., ser., vol. 9, 1900-1902, p. 67, fig. 19 (in text). end.

Variety differing from the typical in having spines at the initial

We can not find any specimen like the present variety in our collection; therefore we have copied Fornasini's figures here.

GLOBULINA TRISERIALIS Cushman and Ozawa, new speciee

Plate 22, figures 1,2

Test globular to oval, more or less acute toward the initial end, circular in cross section; chambers numerous, rounded, much embracing, arranged in an almost triserial series, each succeeding chamber farther removed from the base; sutures not depressed, often obscured; wall smooth, but often the last-formed chamber finely spinose; aperture radiate.

Length $0.40-0.70 \mathrm{~mm}$; breadth $0.33-0.45 \mathrm{~mm}$; thickness 0.28 $0.35 \mathrm{~mm}$.

Holotype-(Cushman Coll. No. 11653.) From the Miocene, Helvetien, Salles, Moulin de Minoy, France. 
The present Globulina is a many chambered species. Its chambers are rounded and short, each succeeding one is removed from the base, and accordingly the test is becoming more or less oval and approaching Pyrulina.

Distribution.-Found only in the Miocene near Bordeaux. Besides the type locality, it occurs in the Burdigalien inferieur, Moulin de l'Eglise, Saucats, France.

\section{GLOBULINA species(?)}

Plate 22, figures $4 a, b$

This peculiar form is figured here for reference. It is Recent from Porcupine Station 16 off the British Isles.

\section{Genus PSEUDOPOLYMORPHINA Cushman and Ozawa, 1928}

\section{PSEUDOPOLYMORPHINA LIGUA (Roemer)}

Plate 22, figures 5, 6

Polymorphina ligua Roemer, Neues Jahrb. für Min. etc., 1838, p. 385, pl. 3, fig. 25.

Polymorphina compressa D'Orbigny, Foram. Foss. Bass. Tert. Vienne, 1846, p. 233, pl. 12, figs. 32-34.-H. B. Brady, Parker, and Jones, Trans. Linn. Soc., vol. 27,1870 , p. 227 , pl. 40 , figs. $12 a-f$.-Schlumberger, Feuille des Jeunes Nat., vol. 12, 1881, pl. 1, fig. 16.-BAGG, U. S. Geol. Survey, Bull. 513, 1912, p. 69, pl. 20, figs. 1-9, 19-21; pl. 21, figs. 9-11. Polymorphina subcompressa D'Orbigny, Prodrome de Paleont., vol. 3, 1852, p. 159 , No. 2976.

Guttulina elongata Karrer, Sitz. Akad. Wiss. Wien, vol. 44, pt. 1, 1861 (1862), p. 448, pl. 2, fig. 3 .

Polymorphina amoena KARRer, Abhandl. k. k. geol. Reichs., vol. 9, 1877, p. 385 , pl. 16 b, fig. 45 .

Polymorphina inequalis D'Orbigny, Ann. Sci. Nat., vol. 7, 1826, p. 265, No. 4.Fornasini, Boll. Soc. Geol. Ital., vol. 19, 1900, p. 142, fig. 3 (in text).

Test oblong, inequilateral, compressed; chambers much longer than wide, slightly inflated, arranged at the start in a quinqueloculine series, becoming biserial later, each succeeding chamber much farther from the base; sutures slightly depressed, distinct; wall smooth, rather thick; aperture radiate.

Length $0.65-2.10 \mathrm{~mm}$; breadth $0.42-0.80 \mathrm{~mm}$; thickness $0.28-$ $0.50 \mathrm{~mm}$.

Polymorphina ligua has long been neglected by later authors. Reuss in 1864 compared the species with Polymorphina acuta and said that they may be identical but Polymorphina acuta is not a Polymorphina, but a Virgulina (examined by Ozawa). H. B. Brady, Parker, and Jones put it in the synonymy of Polymorphina complanata, with doubt.

We examined material from the type locality, Oligocene of Cassel, and found specimens like the figure given by Roemer. Our specimen resembles Polymorphina compressa d'Orbigny, from the Vienna 
Basin (the specific name was changed by d'Orbigny to subcompressa because it is preoccupied by Phillips), and we can find no reason for separating them.

Holotype specimens of Guttulina elongata and Polymorphina amoena, both described by Karrer from Nussdorf in the Vienna Basin, were examined by Ozawa, who found that they are nothing but Polymorphina subcompressa d'Orbigny. They should be included in Pseudopolymorphina ligua.

The original specimen of Polymorphia compressa is lost and the paratype specimens are mostly Virgulina with one specimen resembling the figure of Polymorphina compressa.

Polymorphina inequalis d'Orbigny, figured by Fornasini in 1900, has a rather broad test, but it is not different from the present species in other respects.

Distribution.-Pseudopolymorphina ligua is rare in the Oligocene, but common in various Miocene and Pliocene deposits in Europe. We have specimens from the following localities:

Pliocene.-Belgium, Crag noir, Antwerp. England, Crag, Sutton; Aldeburg, Suffolk.

Miocene.-Austria, Tortonian, Amphistegina marl, Grunes Kreuz, Nussdorf, near Vienna.

Oligocene.-Germany, Ahnatal, near Cassel.

\section{PSEUDOPOLYMORPHINA NOVANGLIAE (Cushman)}

Plate 23, figures 1, 2

Polymorphina lactea (WALKer and $\mathrm{J}_{\mathrm{ACOB}}$ ) var. novangliae Coshman, Bull. 104, U. S. Nat. Mus., pt. 4, 1923, p. 146, pl. 39, figs. 6-8.

Test elongated, more or less compressed, tapering toward the base, either acute or obtuse at the initial end; chambers longer than broad, embracing, arranged at first in a nearly contraclockwise, quinqueloculine series, later becoming more or less biserial; sutures but little depressed, generally distinct; wall smooth, often with fistulose tubes at the apertural end; aperture radiate.

Length $1.15-1.95 \mathrm{~mm}$; breadth $0.55-0.65 \mathrm{~mm}$; thickness $0.20-$ $0.35 \mathrm{~mm}$.

The present species differs from Pseudopolymorphina ligua in the rounded chambers and slightly depressed sutures which give the test a more compact appearance. Its more or less quinqueloculine arrangement of the early chambers is always contraclockwise instead of clockwise, as in $P$. ligua. Its apertural end is often covered by fistulose tubes. Williamson's Polymorphina lactea var. acuminata is an elongated test having an acute initial end, and the arrangement of chambers is similar to that of the present species and is closely related to it. 
Distribution.-This species is apparently confined to the cold water of the American side of the Atlantic, very abundant off the New England coast. Our specimens are from the following localities: Bay on east coast (south of Black Whale Harbor, Hudson Bay), 10 fathoms; Gaspé Bay, 10-40 fathoms; Cobscook Bay; off Trials Island, Eastport, Me.; between Crotch and Stave Islands, Casco Bay, Me., 7 fathoms; shore sand, Coffins Beach, Annisquam, Mass.; beach sand, Newport, R. I. ; one broken specimen, which may be this species, is from off Iceland. It occurs also at Albatross stations in cold water off the New England coast.

\section{PSEUDOPOLYMORPHINA SUBOBLONGA Cushamn and Ozawa, new species}

Plate 23, figures $3 a-c$

Test elongated, the greatest breadth in the upper half, obtuse at the base, acute at the apertural end; chambers twice as long as wide, inflated, slightly overlapping, arranged at first in a quinqueloculine series, later becoming biserial; sutures depressed, distinct; wall smooth, rather thick; aperture radiate.

Length $0.90-1.30 \mathrm{~mm}$; breadth $0.35-0.60 \mathrm{~mm}$; thickness $0.20-$ $0.35 \mathrm{~mm}$.

Holotype-(Cushman Coll. No. 11663.) From upper Pliocene, Okuwa, Province of Kaga, Japan. Paratypes in collection of Geological Institute, Imperial University of Tokyo, Japan.

The present species represents an intermediate form between Guttulina and Pseudopolymorphina, and the arrangement of chambers is not very definite, but generally begins with a quinqueloculine series which becomes more or less biserial later. It differs from Pseudopolymorphina ligua of the European Tertiary in its less regular biserial arrangement of rather short chambers and depressed sutures.

Distribution.-It occurs as an upper Pliocene fossil in Japan and as a living species off the coast. We have specimens from the following localities:

Recent.-Albatross D4807, off Cape Tsiuka, Japan, 44 fathoms.

Upper Pliocene.-Okuwa, Province of Kaga, and Natsukawa, Province of Echigo, Japan.

PSEUDOPOLYMORPHINA SUBOBLONGA var. JUGOSA Cushman and Ozawa, new variety

Plate 23, figures $4 a, b$

Variety differing from the typical form in its surface ornamentation, consisting of a few low longitudinal costae running from the initial end, obscured near the aperture.

Length of holotype $1.05 \mathrm{~mm}$.; breadth $0.30 \mathrm{~mm}$.; thickness 0.25 $\mathrm{mm}$. 
Holotype of variety.-(Cushman Coll. No. 11665.) From Kabama (Sea of Japan), Province of Echizen, Japan. Paratypes in collection of Geological Institute, Imperial University of Tokyo, Japan.

It does not occur with the typical form and is only found as a Recent form.

We have a number of specimens trom the shore sand at Kobama (Sea of Japan), in Province of Echizen. There is also a Recent specimen from Albatross Station D5311 in 88 fathoms, China Sea, off Hongkong.

\section{PSEUDOPOLYMORPHINA STRIATA (Bagg)}

Plate 23, figures $5 a-c$

Polymorphina compressa var. striata BAGG, Maryland Geol. Survey, Miocene, 1904, p. 476, pl. 133, fig. 2.

Polymorphina regina BAGG, Maryland Geol. Survey, Miocene, 1904, p. 478, pl. 133, fig. 7 .

Polymorphina compressa BAGG, Maryland Geol. Survey, Miocene, 1904, p. 476 , pl. 133, fig. 1 .

Test compressed, elongated, base rounded; chambers longer than broad, not much embracing, arranged at first in a nearly contraclockwise, quinqueloculine series, later becoming regularly biserial with the chambèrs alternating; sutures slightly depressed, distinct; wall marked with fine longitudinal costae, typically covering the entire test; aperture radiate.

Adult specimen, length $1.30-1.60 \mathrm{~mm}$; breadth $0.42-0.50 \mathrm{~mm}$; thickness $0.18-0.20 \mathrm{~mm}$.

The present species is different from d'Orbigny's Polymorphina compressa in its arrangement of the early chambers, which is the same as that of $P$. novangliae. From $P$. novangliae it differs in the depressed sutures and more compressed test. The ornamentation of the wall of the test is not always constant, and often a few of the last chambers are without striations.

Distribution.-We have abundant specimens of this species from the Miocene, Choptank formation, 21/2 miles below Governor Run, Chesapeake Bay, Md.; from 1 mile below Governor Run, and from Point of Rocks, about $1 \frac{1}{2}$ miles below Flag Pond, Chesapeake Bay, $\mathrm{Md}$.

\section{PSEUDOPOLYMORPHINA SOLDANII (d'Orbigny)}

Plate 23, figures 6-8

Orthoceratia tuberosa Soldani, Testaceographia, vol. 1, pt. 2, 1791, p. 99, pl., fig. $107 n n$.

Polymorphina soldanii D'Orbigny, Ann. Sci. Nat., vol. 7, 1826, p. 265, No. 12.-Fornasini, Mem. Accad. Sci. Istit. Bologna, ser. 5, vol. 8, 18991900 (1900), p. 388, fig. 38 (in text).-H. B. Brady, PARKer, and Jones, Trans. Linn. Soc., vol. 27, 1870, p. 235, pl. 40, fig. 20.-BAGG, U. S. Geol. Survey, Bull. 513, 1912, p. 74, pl. 19, fig. 8 . 
Polymorphina oblonga Roemer, Neues Jahrb. f. Min. etc., 1838, p. 386, pl. 3, fig. 34 .

Globulina subalpina Gümbel, Abhandl. kön. bay. Akad. Wiss. München, Cl. II, vol. 10, 1868 (1870), p. 646 , pl. 2, figs. $80 a . b$.

Polymorphina obovata Grzy вowski, Pod. Dukli. W. Krakowie, 1894, p. 117, pl. 2 , fig. 23.

Polymorphina proteus Beissel (part), Abhandl. preuss. geol. Landes. Aus., vol. 3,1891 , p. 59 , pl. 11, figs. 4-7 (not 1-3, 8-56; pl. 12, figs. 1-16).

Test elongate, more or less compressed, oblong, rounded at both ends; chambers rounded to oval, arranged at first in a nearly triserial series, later becoming almost biserial; sutures depressed, distinct; wall thick, smooth, often with fistulose tubes; aperture radiate.

Length $1.05-1.50 \mathrm{~mm}$.; breadth $0.50-0.80 \mathrm{~mm}$.; thickness 0.28 $0.40 \mathrm{~mm}$.

In their monograph of Polymorphina, H. B. Brady, Parker, and Jones placed Polymorphina soldanii d'Orbigny, Polymorphina oblonga d'Orbigny (not Roemer), and Polymorphina uvaeformis together, but in the Challenger report Brady separated d'Orbigny's $P$. oblonga from $P$. soldanii without giving any notes.

Pseudopolymorphina soldanii is undoubtedly related to Guttulina oblonga d'Orbigny. From such a form it might be derived by losing its quinqueloculine arrangement of chambers and the chambers becoming shorter and rounded. The present species seems to be very variable in its form. The figures given by Fornasini are much broader than the figures copied by Brady, Parker, and Jones, though both figures present the same general characters.

Polymorphina oblonga Roemer and P. obovata Grzybowski are apparently the same, judged by the figures, and both have compressed tests consisting of rather short, rounded chambers arranged in a somewhat biserial series. After having examined German Oligocene material from several localities, among which there are specimens resembling Polymorphina oblonga Roemer, as well as Pseudopolymorphina soldanii, we are convinced that they should be united.

Figures 4-7 in plate 11 of Polymorphina proteus Beissel, show a biserial arrangement of short chambers and are very close to the present species.

We have several Upper Cretaceous specimens of Pseudopolymorphina soldanii from Maastricht, which are almost the same as Beissel's figures above mentioned.

Polymorphina subalpina Gümbel is also included in the present species with some doubts.

Distribution.-There are specimens in our collection from the following localities:

Pliocene.-England, Crag, Sutton. 
Miocene.-France, Helvetian, Pontlevoy; Moulin du Minoy, Salles; Burdigalien inferieur, Le Coquillat, Leognan; Moulin de l'Eglise, Saucats.

Oligocene.-Germany, Ahnatal, near Cassel.

Cretaceous.-Holland, Maastricht (?).

\section{PSEUDOPOLYMORPHINA HANZA WAI Cushman and Ozawa}

Plate 24, figures $1 a, b$

Pseudopolymorphina hanzawai Cushman and Ozawa, Contr. Cushman Lab. Foram. Res., vol. 4, 1928, p. 16, pl. 1, fig. 15; Jap. Journ. Geol. Geogr., vol. 6,1929 , p. 69 , pl. 13, fig. 4 ; pl. 14, fig. 11 ; pl. 15, figs. 3,4 .

Test large, about twice as long as broad, the later portion somewhat compressed and tending to become biserial in the last chambers, greatest breadth above the middle, broadly rounded at the base; chambers numerous, only slightly longer than broad, arranged in an elongate, closed, sigmoid series becoming biserial; sutures distinct, but very slightly depressed; wall thick, smooth, translucent; aperture radiate, terminal.

Measurements of the figured specimens: $2.25-2.40 \mathrm{~mm}$; breadth 1.10-1.26 mm.; thickness $0.85 \mathrm{~mm}$.

This species differs from Guitulina spicaeformis (Roemer) in its biseral form in the adult and in the very much larger size. It is more closely related to Guttulina yabei from which it is probably derived by the addition of the biserial character.

Distribution.-The types of this species are from the Pliocene of Sawane, Island of Sado, Japan. It also occurs in the Pliocene of Okuwa, Province of Kaga, Japan. We have somewhat similar specimens from Albatross Station D2416 in 276 fathoms off the Carolina coast and a single specimen which much resembles this from the Miocene, Burdigalien moyen, of Le Coquillat, Leognan, France.

PSEUDOPOLYMORPHINA ATLANTICA Cushman and Ozawa, new species

Plate 24, figures $2 a, b$

Polymorphina compressa FuINT (not d'Orbigny), U. S. Nat. Mus., Rept., 1897 (1899), p. 319, pl. 67, fig. 3.

Test ovate (young) to fusiform (adult), obtuse at the base, acute at the apertural end, slightly compressed; chambers nearly clavate, not much overlapping, arranged in a nearly triserial series at the start, becoming biserial later; sutures depressed, distinct; wall smooth, thick; aperture radiate.

Figured specimen, length $1.50 \mathrm{~mm}$.; breadth $0.75 \mathrm{~mm}$.; thickness $0.32 \mathrm{~mm}$.

Holotype.-(U. S. Nat. Mus. Coll. No. 20955.) From Albatross dredgings off the eastern coast of the United States. 
Flint's Polymorphina compressa, described in 1897 , is quite different from d'Orbigny's species, figured in 1846, from the Vienna Basin in its broader test and depressed sutures, and its earlier chambers are more rounded and inflated and the sutures are generally much oblique. Our specimens examined are those described by Flint.

Distribution.-Only known off the Atlantic coast of the United States, 88-440 fathoms. Doctor Flint selected a set of specimens from several stations along the Atlantic coast, but did not keep separate those from the different stations, and so the exact station can not be given.

\section{PSEUDOPOLYMORPHINA PHALEROPEI Cushman and Ozawa, new species}

Plate 24, figures $3 a, b$

Test oblong, but little compressed, rounded at the base; periphery broadly rounded; chambers inflated, as long as wide, slightly embracing, arranged in a nearly biserial series; sutures depressed, very distinct; wall thin, smooth, transparent; aperture radiate.

Length $0.70 \mathrm{~mm}$.; breadth $0.42 \mathrm{~mm}$.; thickness $0.30 \mathrm{~mm}$.

Holotype.-(Cushman Coll. No. 2237.) From the Atlantic coast of Massachusetts in the Woods Hole region, dredged by the United States fisheries steamer Phalerope.

Its round and inflated chambers separated by the deep sutures are the most important character of the species, and there is no other species of the genus which is likely to be confused with the present one.

\section{PSEUDOPOLYMORPHINA PARVA (Clodius)}

Plate 24, figures $4 a, b$

Polymorphina (Guttulina) parva Clodius, Archiv. Ver. Fremde Nat. Mecklenburg, 75 Jahrg, 1922, p. 127, pl. 1, fig. $10 a, b$.

Test elongate, subfusiform, more or less compressed; chambers spherical, arranged in a quinqueloculine series, becoming biserial later; sutures much depressed, distinct; wall smooth, thick; aperture radiate.

Pseudopolymorphina parva is unique in its spherical chambers separated by very deep sutures.

We have no specimen of the present species.

\section{PSEUDOPOLYMORPHINA DOANEI (Galloway and Wissler)}

Plate 24, figures $5 a, b$

Polymorphina doanei Galloway and Wissler, Journ. Pal., vol. 1, 1927, p. 54 , pl. 9 , fig. 8 .

Bulimina contraria BAGG (not Reuss), Bull. 513, U. S. Geol. Survey, 1912, p. 37 , pl. 9, fig. 2 .

Polymorphina nodosaria BAGG, Bull. 513, U. S. Geol. Survey, 1912, p. 71, pl. 21, figs. 2,3 (not fig. 1 ). 
Test but little compressed, elongated, the greatest breadth in the upper half, gradually tapering toward the base, initial end obtuse; chambers rounded, but little embracing, arranged at first in a quinqueloculine series, abruptly becoming biserial, in full grown specimens the later ones tending to become somewhat uniserial, each succeeding chamber very much farther removed from the base; sutures much depressed, very distinct; wall thick, smooth; aperture radiate.

Length of figured specimen $2.20 \mathrm{~mm}$.; breadth $0.65 \mathrm{~mm}$; thickness $0.50 \mathrm{~mm}$.

In general appearance this species is almost identical with Pseudopolymorphina parva excepting its slightly more rounded initial end. It may be possible that the present species is the megalospheric form of $P$. parva. However, as we have no European or topotype specimens representing $P$. parva, we can not definitely say that they are the same species. Therefore until we examine the original specimen $P$. doanei is kept as a good species and is described here.

It is only known from the Pleistocene and Pliocene of California, in which it is rather common.

Galloway and Wissler described it from the lower bed at the D. M. S. and B. quarry, and noted its occurrence in the Pliocene of Timms Point, San Pedro, Calif. We have a series of specimens from both of these localities.

\section{PSEUDOPOLYMORPHINA DECORA (Reuss)}

Plate 24, figures 6-8

Polymorphina decora Reuss, Bull. Acad. Roy. Sci. Belg., ser. 2, vol. 15, 1863 : p. 152 , pl. 3, fig. 41 .

Polymorphina texana Cushman and Applin, Bull. Amer. Assuc. Petr. Geol., vol. 10,1926, p. 173 , pl. 9 , figs. 1,2 .

Test elongated, more or less compressed, periphery rounded, sides nearly parallel; chambers somewhat longer than wide, slightly embracing, alternating, arranged in a nearly biserial series from the start; sutures not depressed, distinct; wall smooth; aperture radiate.

Length $0.75-1.10 \mathrm{~mm}$.; breadth $0.32-0.36 \mathrm{~mm}$.; thickness $0.15-0.18$ $\mathrm{mm}$.

Polymorphina decora, figured by Reuss from the Crag of Antwerp, is evidently a young, few-chambered specimen. An adult manychambered specimen is much elongated with the sides almost parallel.

It resembles Pseudopolymorphina spatulata (Terquem) in its general appearance, but the latter has a thicker test with rather inflated chambers and slightly depressed sutures. These differences are not very distinctive, and there are transitional forms.

Distribution.-Rather common in the Miocene deposits near Bordeaux. Somewhat similar specimens occur in the Eocene of France. 
Miocene.-France, Aquitanian superieur, near Mont de Marsan, St. Avit; Burdigalien superieur, Pont Pourquet, Saucats; Burdigalien inferieur, St. Paul de Dax, Dax; Le Coquillat, Leognan; Moulin de l'Eglise, Saucats.

Eocene.-France, Calcaire grossier, Beauves; Lutetien, Chaussy.

\section{PSEUDOPOLYMORPHINA DUMBLEI (Cushman and Applin)}

Plate 25, figures $1 a, b$

Polymorphina compressa D'Orbigny var. dumblei Cushman and Applin, Bull. Amer. Assoc. Petr. Geol., vol. 10, 1926, p. 173, pl. 9, figs. 4, 5.

Test compressed, elongated, obtuse at the base, more or less acute at the apertural end; chambers slightly longer than wide, more or less compressed, much embracing, arranged at first in a nearly triserial series becoming biserial later; sutures but little depressed, distinct; wall smooth; aperture radiate.

Length $0.70-1.10 \mathrm{~mm}$.; breadth $0.35-0.40 \mathrm{~mm}$.; thickness $0.16-0.20$ $\mathrm{mm}$.

The present species is an ally of Pseudopolymorphina decora of the European Tertiary, and it is often difficult to separate them. The important difference is the shape of chambers, which in the present species are shorter than those of the European species.

Polymorphina texana is a few-chambered species representing a young stage of $P$. decora.

Distribution.-This was originally described as a variety of $P$. compressa but is not related to that species. The types are from the upper Eocene of Texas. It is found in the upper Eocene of Texas, Alabama, and Georgia as well as in samples from Mexico referred to the Alazan clays. Single specimens from the Miocene and the Claiborne are close to this species as well as a few from the Midway, but more material will give added light on their exact relationships. We have no European material to place with this.

Our specimens are from the following localities:

Miocene.-Florida, Choctawhatchee marl, 1 mile east of Red Bay.

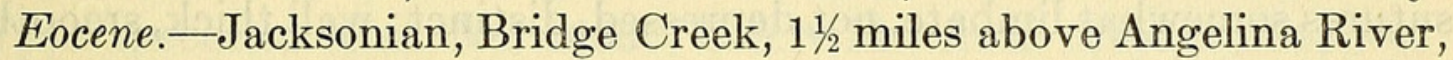
Texas; Powells Landing, east bank of Sepulga River, sec. 35, T. 4 N., R. 13 E., Covington County, Ala.; Conecuh River at Beck, Covington County, Ala.; Cocoa sand, Keysers Hill, one-fourth mile west of Water Valley, Choctaw County, Ala. Jackson, on old Waynesboro Road, 5 miles north of Millen, Jenkins County, Ga.; Rich Hill, Crawford County, Ga. Mexico, Alazan shale, Rio Buena Vista, 9.8 kilometers upstream from Tumbadero, Vera Cruz; Rio Tuxpam, south side just above Agua Nacida, Vera Cruz, Mexico.

$92709-30-7$ 
Plate 25, figures 2, 3

Pseudopolymorphina compressa D'ORBIGNY var. okuwaensis CUSHMAN and Ozaw A, Jap. Journ. Geol. Geogr., vol. 6, 1929, p. 72, pl. 13, fig. 7; pl. 15, figs. 8,9 .

Test compressed, elongated, rounded at the base, acute at the apertural end, margin nearly parallel; chambers slightly compressed, as long as wide, slightly embracing, arranged at first in a nearly triserial series (the microspheric form) later becoming biserial; sutures generally slightly depressed, distinct; wall smooth, thick; aperture radiate.

Length $0.85-1.10 \mathrm{~mm}$.; bread th $0.36-0.50 \mathrm{~mm}$.; thickness $0.15-0.27$ $\mathrm{mm}$.

We formerly described this as a variety of Pseudopolymorphina compressa, but it is very distinct from the latter in its much shorter chambers. It may be compared with the European Pseudopolymorphina decora and American Eocene $P$. dumblei, with which it may be closely related. Its distinction from these two is in the round short chambers, but there are intermediate forms among the above three species.

Distribution.-It is quite abundant in the Japanese Pliocene as well as now living in the same general region.

Recent.-Kobama, Inland Sea of Japan, Province of Echizen, Japan. Upper Pliocene.-Okuwa, Province of Kaga, Japan.

PSEUDOPOLYMORPHINA ISHIKA WAENSIS Cushman and Ozawa

Plate 25, figures 4,6

Pseudopolymorphina ishikawaensis Cushman and Ozawa, Jap. Journ. Geol. Geogr., vol. 6, 1929, p. 70, pl. 13, fig. 5; pl. 15, fig. 5

Test much elongated, somewhat compressed, but the periphery broadly rounded, sides in the adult portion nearly parallel; chambers numerous, biserial, somewhat inflated, only slightly overlapping; sutures somewhat limbate, not depressed, distinct; wall thick, smooth; aperture radiate.

Length 2.30-2.70 mm.; breadth $0.70-0.78 \mathrm{~mm}$; thickness $0-48-$ $0.52 \mathrm{~mm}$.

The elongate and narrow test consisting of oval chambers which are arranged in an almost entirely biserial series will distinguish it from any other species of the genus.

Distribution.-The types of this species are from the Upper Pliocene of Okuwa, Province of Kaga, Japan. It also occurs in the upper Pliocene of Natsukawa, Province of Echigo, and Dainichi, Province of Totomi, Japan. The same species occurs in the Upper Miocene of Kumonyo, Province of Totomi, Japan. 


\section{PSEUDOPOLYMORPHINA ZEUSCHNERI (ReusS)}

Plate 25, figures $5 a-c$

Polymorphina zeuschneri Reuss, Sitz. Akad. Wiss. Wien, vol. 55, pt. 1, 1867, p. 90 , pl. 4 , fig. 1.

Test oblong to more or less fusiform, compressed, broadest at the upper half, rather acute at the initial end; chambers rounded, compressed, arranged in a biserial series; sutures depressed but little, distinct; wall smooth; aperture radiate.

Length of figured specimen $0.80 \mathrm{~mm}$; breadth $0.50 \mathrm{~mm}$; thickness $0.30 \mathrm{~mm}$.

The specimen described by Reuss comes from "Salzthon" and "Steinsalz" in Galicia. We have a specimen from the Miocene of Varpolata in Hungary which is not much different in its foraminiferal fauna from the formation in Galicia.

Polymorphina consecta d'Orbigny, figured later by Fornasini, is from the Miocene of Dax and shows a close resemblance to the present species.

\section{PSEUDOPOLYMORPHINA INDHCA (Cushman)}

\section{Plate 25, figures $7 a, b$}

Polymorphina problema D'ORBIGny var. indica Cushman, Bull. 100, U. S. Nat. Mus., vol. 4, 1921, p. 265, pl. 52, figs. 1, 2; pl. 53, figs. $1 a, b$.

Test large, broad, oblong, but little compressed; chambers inflated, rounded, arranged at first in a quinqueloculine series, later becoming more or less biserial; each succeeding chamber removed farther from the base; sutures much depressed, distinct; wall thick, that of earlier chambers and the posterior half of the later ones with fine longitudinal costae; aperture radiate.

Maximum length $2.50 \mathrm{~mm}$.; breadth $1.60 \mathrm{~mm}$.; thickness $1.00 \mathrm{~mm}$.

The present species is close to Guttulina regina from which it is evidently derived by losing the quinqueloculine arrangement of chambers. The surface ornamentation is not definite, and that of the later chambers is often obscured.

Type specimen (Cat. No. 16056, U.S.N.M.) from Albatross Station D5579, off Sibuko Bay, Borneo, in 75 fathoms (320 m.).

Distribution.-We have three specimens from the type locality. The species also occurs at the neighboring Albatross Station D5580, off Sibuko Bay, in 162 fathoms. A single specimen from off Amino, Japan, completes the known distribution.

PSE UDOPOLYMORPHINA INDICA (Cushman) var. JAPONICA Cushman and Ozawa

Plate 26, figures 1, 2

Pseudopolymorphina indica (Cushman) var. japonica Cushman and Ozawa, Jap. Journ. Geol. Geogr., vol. 6, 1929, p. 71, pl. 13, fig. 6; pl. 15, fig. 6 .

Polymorphina costata Allix, Feuille des Jeunes Naturalistes, vol. 43, 1913, p. 41 , fig. 6 (in text) (?). 
Variety differing from the typical form in having the later chambers more regularly biserial and accordingly the test more compressed.

Length of holotype $3.10 \mathrm{~mm}$; breadth $1.87 \mathrm{~mm}$.; thickness $0.81 \mathrm{~mm}$.

Polymorphina costata Allix reported from the Miocene of Touraine appears to be a young specimen of the present species. We have a specimen like Allix's figure from the Miocene of Pontlevoy. This specimen is fistulose and resembles the young stage of the megalospheric form of Pseudopolymorphina indica var. japonica. We can not say definitely whether or not Allix's species is identical with the present variety. The specific name costata of Allix's species is preoccupied by Egger in 1856, and therefore the present varietal name is not disturbed by his species.

The types of this variety are from the Pliocene of Sawane, island of Sado, Japan. The specimen figured here is from Albatross Station D4807, 44 fathoms, off Cape Tsiuka, Japan.

\section{PSEUDOPOLYMORPHINA RUTILA (Cushman)}

Plate 26, figures $3 a, b$

Polymorphina regina H. B. BRAdy, PARKer, and Jones var. rutila Cushman, U. S. Geol. Survey Prof. Paper 133, 1923, p. 34, pl. 5, figs. 7, 8.

Test compressed, elongate, fusiform, with a strong spine at the base; chambers more or less elongated, not much embracing, alternating; sutures more or less depressed, distinct; wall marked with a few strong, longitudinal costae; aperture radiate.

Maximum length $1.30 \mathrm{~mm}$.; breadth $0.22 \mathrm{~mm}$.; thickness $0.14 \mathrm{~mm}$.

This species is undoubtedly derived from Guttulina costulata Cushman by greatly reducing the quinqueloculine arrangement of chambers in the young. Like Guttulina costulata, it is conspicuous by its surface ornamentation.

Distribution.-This species was described from the lower Oligocene, the Byram calcareous marl at Leaf River, Miss. It occurs also in the Byram marl at Byram, Miss.

PSEUDOPOLYMORPHINA RUTILA (Cushman) var. PARRI Cushman and Ozawa, new variety

Variety differing from the typical in the somewhat broader test and coarser costae.

Holotype of variety.-(Cushman Coll. No. 7833.) From Miocene, Janjukian, soapy clay bed in Polyzoal limestone, Danger Point, Torquay, Victoria, Australia.

This variety is named for Mr. W. J. Parr, of Australia, whose interesting collections have afforded us opportunity to study many of the Australian forms. 
Plate 26, figures $4 a, b$

Test compressed, elongated, greatest breadth in the upper half, gradually tapering toward the initial end; chambers more or less compressed, arranged in a biserial series; sutures slightly depressed, distinct; wall thick, ornamented by a few low longitudinal costae, which are often obscured; aperture radiate.

Length of holotype $1.20 \mathrm{~mm}$; breadth $0.50 \mathrm{~mm}$.

Holotype-(Cat. No. 371261, U.S.N.M.) From Midway Eocene, U. S. G. S. Station $1 / 797$, on west or downthrow side of fault, 2 miles northwest of Lone Oak, Hunt County, Texas.

Its more or less lance-shaped test and coarse longitudinal ornamentation are the important characteristics to separate the present species from any others of the genus.

\section{PSEUDOPOLYMORPHINA OBSCURICOSTATA (Galloway and Wissler) (?)}

Plate 39, figure 6

Polymorphina obscuricostata Galloway and Wissler, Journ. Pal., vol. 1, 1927 , p. 56 , pl. 9, fig. 12 (P. obscurocostata on explanation of plate).

Test compressed, irregularly oval in side view; chambers few, compressed, longer than wide, not much embracing, arranged in a biserial series; sutures slightly depressed, distinct; wall ornamented with about six low obscure costae to a side, extending from the rounded initial end about two-thirds of the way to the aperture; aperture radiate.

Length of the specimen $0.22 \mathrm{~mm}$; width $0.13 \mathrm{~mm}$.; thickness 0.05 $\mathrm{mm}$

The present species is undoubtedly a young specimen of an ornamented Pseudopolymorphina. It resembles Pseudopolymorphina indica and its variety, but the chambers are more elongated and the costae are fewer; therefore we keep it as a good species.

The above description is mainly copied from the original.

Distribution.-Galloway and Wissler described the species from a single specimen which is from the Pleistocene, middle bed, in the D. M. S. and B. quarry, near Lomita, Palos Verdes Hills, Calif.

PSEUDOPOLYMORPHINA VARIATA (Jones, Parker, and H. B. Brady)

Plate 26, figures 5, 6

Polymorphina variata Jones, Parker, and H. B. Brady, Foram. Crag, pt. 1, 1866, pl. 1, figs. 67, 68.-H. B. Brady, PARKer, and Jones, Trans. Linn. Soc., vol. 27, 1870, p. 237, pl. 40, fig. 24.-Jones, Foram. Crag, pt. 2,1895 , pl. 5 , fig. 27 ; pt. 3,1896 , p. 272.

Test suboblong to oblong, compressed, the greatest breadth above the middle; chambers rounded, compressed, arranged in an almost biserial series from the beginning; sutures depressed, but not very 
distinct; wall studded with irregular, angular, low elevations imparting a mottled appearance to the exterior, sometimes marked with strong angular elevations unequally distributed; aperture radiate.

Maximum length $1.60 \mathrm{~mm}$.; breadth $1.25 \mathrm{~mm}$; thickness $0.30 \mathrm{~mm}$.

The present very interesting species is described from the Crag of Sutton for the first time by Jones, Parker, and H. B. Brady, who characterize the species as having the surface with irregular and angular depressions. We have examined material from the same locality and found several specimens showing the same characters as Pseudopolymorphina variata excepting surface ornamentation. Our specimens are ornamented with irregular elevations instead of depressions. We have well preserved specimens from the Miocene of Pontlevoy in France, which are marked by graphically distributed elevations imparting to the surface an appearance of depressions at lower magnification.

Terquem figured two different specimens obtained from the Pliocene of the Isle of Rhodes under the name Polymorphina fischeri. One has a smooth surface, while the other has a many-chambered elongate test, the wall of which, according to his description, is rugose or arenaceous. If his specimen really belongs to the Polymorphinidae, we may suppose it may be rugose and not arenaceous. His smooth specimen is separated as a variety of the present species.

Distribution.-The species seems to be limited to the late Tertiary in Europe. Brady, Parker, and Jones's specimens are from the Crag of Sutton, where it is rather common. We have specimens from the type locality at Sutton and from the Miocene of Pontlevoy, France. Terquem's rough specimen from the Pliocene of the Isle of Rhodes is probably to be placed under this species.

PSEUDOPOLYMORPHINA VARIATA (Jones, Parker, and H. B. Brady) var. FISCHERI (Terquem)

Plate 10, figures 6, 7; Plate 26, figures 7, 8

Polymorphina fischeri Terquem, Mém. Soc. Géol. France, sér. 3, vol. 1, 1878, p. 41 , pl. 3 (8), figs. 37,39 .

Guttulina racemosa Terouem, Mém. Soc. Géol. France, sér. 3, vol. 1, 1878, p. 46 , pl. 4 (9), figs. 20-22 (not figs. 23,24 ).

Polymorphina compressa Jones, Foram. Crag, pt. 3, 1896, p. 258, pl. 1, figs. $54,65,77-80$; and (distorted) pl. 5, figs. 26, 28.

Polymorphina dilatata D'Orbigny, Ann. Sci. Nat., vol. 7, 1826, p. 265, No. 11.-Fornasini, Riv. Ital. Pal., vol. 8, 1902, p. 2, pl. 1, fig. 5.

Polymorphina lecointreae Allix, Feuille des Jeunes Naturalistres, vol. 43, 1913 , p. 34 , fig. 5 (in text).

Polymorphina consecta D'Orbigny, Ann. Sci. Nat., vol. 7, 1826, p. 265, No. 10.-Fornasini, Riv. Ital. Pal., vol. 8, 1902, p. 2, pl. 1, fig. 4.

Variety differing from the typical form in having a smooth surface. Maximum length $2 \mathrm{~mm}$; breadth $1.30 \mathrm{~mm}$.; thickness $0.50 \mathrm{~mm}$. 
As remarked in the case of the typical form, Terquem's species, Polymorphina fischeri, contains both smooth and ornamented forms. The form having a smooth surface is described and figured before the ornamented form, which coincides with Pseudopolymorphina variata. Therefore Terquem's specific name fischeri is used as a varietal name for the smooth variety of $P$. variata.

Jones included a smooth variety from the Crag in Polymorphina compressa, but their difference is very conspicuous. The present variety has compressed but more rounded chambers instead of elongated chambers as in Polymorphina compressa.

Polymorphina dilatata listed by d'Orbigny and figured by Fornasini, considered from the figure, is very close to the present variety. Polymorphina lecointreae Allix, as reported from the Miocene of Touraine, has rather rounded chambers separated by more or less depressed sutures, and may be included in the range of variation of the present variety.

Some figures of Guttulina racemosa Terquem described in the same paper as the present variety appear to be very similar to a young stage of the present variety. They are probably young specimens. Two specimens somewhat resembling Terquem's Guttulina racemosa are figured.

Distribution.-The present variety generally occurs associated with the typical form, and it seems to be limited to the late Tertiary of Europe. The localities of our identified specimens are as follows:

Pliocene.-Crag, of Suffolk, England. Isle of Rhodes.

Upper Miocene.-Pontlevoy, France; near Bordeaux, France.

PSEUDOPOLYMORPHINA OVALIS Cushman and Ozawa, new name

Plate.27, figures $1 a-c$; Plate 29, figures $6 a-c$

Polymorphina ovata D'Orbigny, Foram. Foss. Bass. Tert. Vienne, 1846, p. 233, pl. 13, figs. 1-3 (not of 1826).-H. B. Brady, Rep. Voy. Challenger, Zoology, vol. 9, 1884, p. 564, pl. 72, figs. 7, 8.-Cushman, Bull. 104, U. S. Nat. Mus., pt. 4, 1923, p. 151, pl. 40, figs. 11, 12.

Test fusiform, more or less compressed, elliptical in end view; chambers inflated, much embracing, arranged in a nearly biserial series, each succeeding chamber not much removed from the base; sutures but little depressed, fairly distinct; wall smooth; aperture radiate.

Length $0.85 \mathrm{~mm}$.; breadth $0.65 \mathrm{~mm}$.

D'Orbigny's Polymorphina ovata, described in the Vienna monograph, is evidently different from Polymorphina (Globulina) ovata, named in 1826, but was neither figured nor described by d'Orbigny. Polymorphina ovata, therefore, as a specific name can not be used, and a new name ovalis is proposed. 
Pseudopolymorphina ovalis has a more or less compact test, consisting of rather inflated chambers arranged in an almost biserial series, and it is more or less related to Pyrulina, but the compressed fusiform test having the chambers arranged in a biserial series shows a closer relationship of the present species to Pseudopolymorphina, where we have placed it.

Distribution.-Pseudopolymorphina ovalis is rather rare in the Amphistegina marl of Grunes Kreuz, Nussdorf, in Vienna. It is rarely found in the Recent state, and the specimens noted below are not entirely typical. We have specimens of the present species from the following localities:

Recent.-Albatross Station D3407, in 885 fathoms off the Galapagos Islands, and D4807 in 44 fathoms off Japan. Single specimens from each station are larger than the typical form and may not be the same.

Pliocene.-Belgium, Crag noir, Antwerp.

Miocene.-Austria, Tortonian, Amphistegina marl, Grunes Kreuz, Nussdorf, near Vienna. Hungary, Kostej, Banat. France, Burdigalien inferieur, Moulin de l'Eglise, Saucats.

\section{PSEUDOPOLYMORPHINA OBSCURA (Roemer)}

Plate 27, figures $2 a-b$

Polymorphina obscura Roemer, Neues Jahrb.f. Min., etc., 1838, p. 385, pl. 3, fig. 23.-Reuss, Sitz. Akad. Wiss. Wien, vol. 50, abt. 1, 1864, p. 471, pl. 3, figs. 8-10.

Polymorphina teretiuscula Roemer, Neues Jahrb. f. Min., etc., 1838, p. 385, pl. 3, fig. 24 .

Polymorphina campanulata Roemer, Neues Jahrb. f. Min., etc., 1838, p. 385, pl. 3, fig. 22 .

Polymorphina subdepressa Roemer, Neues Jahrb. f. Min., etc., 1838, p. 385, pl. 3, fig. 28 .

Test elongate, compressed, sides nearly parallel, slightly broader near the apertural end, initial end rounded; chambers not elongated, slightly embracing, arranged at first in a quinqueloculine series, and later biserial; sutures but little depressed, distinct; wall thick, smooth; aperture radiate.

Length of figured specimen $3.30 \mathrm{~mm}$.; breadth $1.25 \mathrm{~mm}$.; thickness $0.65 \mathrm{~mm}$.

We have the same opinion as Reuss, who in the paper on the fauna of the German upper Oligocene, published in 1864, put together under P. obscura: Polymorphina obscura, $P$. teretiuscula, and $P$. campanulata figured by Roemer.

Polymorphina subdepressa v. Münster, described for the first time by Roemer in the same paper as the above three, has a much rounded initial end, few chambers, and short test, and may be considered as the megalospheric form of the present species. The early chambers are not biserial, and for this reason we have placed the species in Pseudopolymorphina. 
Distribution.-We have a good series of the present species from the upper Oligocene of Ahnatal, near Cassel, Germany. There is a single specimen in the collection from the Oligocene of Lattdorf, Germany.

PSEUDOPOLYMORPHINA CURTA Cushman and Ozawa, new species

Plate 27, figures $3 a, b$

Pseudopolymorphina species Cushman and Ozawa, Jap. Journ. Geol. and Geogr., vol. 6, 1929, p. 71, pl. 15, fig. 7 .

Test oval, compressed, rounded at both ends, margin even; chambers few, as long as wide, more or less compressed, slightly embracing, arranged in an almost biserial series; sutures but little depressed, often obscured; wall thin, smooth; aperture radiate.

Length of holotype $0.55 \mathrm{~mm}$.; breadth $0.40 \mathrm{~mm}$; thickness $0.27 \mathrm{~mm}$.

Holotype.-(Cushman Coll. No. 11731.) From 32 fathoms, one-half mile northwest of Eagle Island, Casco Bay, Me.

A characteristic of the species is the oval test composed of a few more or less compressed rounded chambers. Pseudopolymorphina species recorded by us from the upper Pliocene of Sawane, Japan, is very similar to the present species.

Distribution.-In addition to the above localities, we have specimens from Hudson Bay, Richmond Gulf (about 3 miles from entrance, in $15-20$ fathoms).

\section{PSEUDOPOLYMORPHINA SPATULATA (Terquem)}

Plate 27, figures 4, 5

Polymorphina spatulata Terouem, Mém. Soc. Géol. France, sér. 3, vol. 2, 1882 , p. 142 , pl. 14 (22), figs. $32 a, b$.

Polymorphina truncata D'Orbigny, Ann. Sci. Nat., vol. 7, 1826, p. 265, No. 3.-Fornasini, Boll. Soc. Geol. Ital., vol. 19, 1900, p. 152, fig. 6 (in text).

Test slightly compressed, elongated, periphery broadly rounded; chambers inflated, slightly overlapping, arranged at first in a nearly quinqueloculine or triloculine series especially in the microspheric form, abruptly becoming biserial; sutures but little depressed, distinct; wall smooth; aperture radiate.

Maximum length $2.30 \mathrm{~mm}$; ; breadth $0.55 \mathrm{~mm}$.; thickness $0.30 \mathrm{~mm}$.

As is noted in the remark given with Pseudopolymorphina decora, it is difficult to distinguish Pseudopolymorphina spatulata from Pseudopolymorphina decora because of transitional forms. Especially the megalospheric form of the present species, having an almost biserial test, shows a great resemblance to Pseudopolymorphina decora.

Polymorphina truncata d'Orbigny, figured by Fornasini, having alternating rounded chambers, is not different from the present species, although its apertural view is almost circular. 
Distribution.-Our specimens are mostly from the Miocene of France, where the species is common and well developed. We have specimens from the following localities:

Miocene.-France, Aquitanian superieur, St. Avit, near Mont de Marson, near Bordeaux; Burdigalien superieur, Merignac (Gironde); Burdigalien inferieur, Le Coquillat, Leognan; Moulin de l'Eglise, Saucats.

Oligocene.-Upper, Germany, Ahnatal, near Cassel.

PSEUDOPOLYMORPHINA DOLLFUSSI Cushman and Ozawa, new species

Plate 27, figures 6,7

Test cylindrical, but little compressed, rounded at the base, obtuse at the apertural end; chambers elongated, not much embracing, arranged at first in a triserial series, becoming biserial later, each succeeding chamber removed much farther from the base; sutures very little depressed, not very distinct; wall rather thin, smooth; aperture large, radiate.

Length $0.95-1.40 \mathrm{~mm}$.; breadth $0.28-0.35 \mathrm{~mm}$.; thickness $0.18-0.22$ $\mathrm{mm}$.

Holotype.-(Cushman Coll. No. 11739.) From the Miocene, Burdigalien inferieur, Le Coquillat, Leognan, France. Paratype in collection of Geological Institute, Imperial University of Tokyo, Tokyo, Japan.

The present species has a tendency to become more or less uniserial in the later stages, but the sutures are invariably oblique and the chambers alternating.

This species is named for Dr. G. Dollfuss, of Paris, formerly President of the Société Géologique of France, who furnished excellent material from the Miocene of France for our studies.

Distribution.-This species occurs in the Miocene of France. We have specimens from the following localities:

Miocene.-Aquitanian superieur, La Brede, Larriey, near Bordeaux; Burdigalien superieur, Merignac (Gironde); Burdigalien inferieur, La Coquillat, Leognan.

PSEUDOPOLYMORPHINA DOLLFUSSI Cushman and Ozawa var. TENUISTRIATA Cushman and Ozawa, new variety

Plate 27, figures $8 a, b$

Variety differing from the typical in the ornamentation of the test, which consists of very fine longitudinal striations.

Length $0.80-1.10 \mathrm{~mm}$; breadth $0.18-0.25 \mathrm{~mm}$.; thickness $0.15-$ $0.22 \mathrm{~mm}$.

Holotype of variety.--(Cushman Coll. No. 11743.) From the Miocene of St. Paul de Dax, near Bordeaux, France. Paratypes in the collection of the University of Tokyo. 
PSEUDOPOLYMORPHINA JONESI Cushman and Ozawa, new species

Plate 28, figures $1 a-c$

Polymorphina nodosaria Jones, Foram. Crag, pt. 3, 1896, p. 262, pl. 1, figs. 55-58 (Dimorphina).

Polymorphina thouini Jones (not d'Orbigny), Foram. Crag, pt. 3, 1896, p. 261 , pl. 1 , fig. 59 .

Test cylindrical, elongated, rounded at the base; chambers as long as wide, circular in transverse section, arranged at the beginning in a triserial series, later becoming uniserial; sutures but little depressed, distinct; wall smooth; aperture radiate.

Length of holotype $1.60 \mathrm{~mm}$; ; breadth $0.35 \mathrm{~mm}$.

Holotype.-(Cushman Coll. No. 11745.) From Miocene, Burdigalien of St. Paul de Dax, near Bordeaux, France.

Pseudopolymorphina jonesi is different from Reuss's Polymorphina nodosaria and $P$. subnodosa in having the chambers not inflated and the sutures not depressed. Jones's Polymorphina nodosaria and $P$. thouini, figured from the Coralline Crag of Sutton, are the same as the present species. It may be noticed here that d'Orbigny's $D i$ morphina nodosaria, described from the Vienna Basin, is a Marginulina.

Distribution.-Jones's specimens were from the Pliocene Crag of Sutton, England. We have specimens also from the Miocene of St. Paul de Dax, near Bordeaux, France.

\section{PSEUDOPOLYMORPHINA SUBCYLINDRICA (Hantken)}

Plate 28, figures $2 a-c$

Polymorphina subcylindrica Hantren, A Magy. Kir. földt. int. evkönyve, vol. 4, 1875 (1876), p. 51, pl. 14, fig. 14; Mitth. a. d. Jahrb. k. ungar. geol. Anstalt, vol. 4, 1875 (1881), p. 60, same pl. and fig. (misprinted subcyindrica in explanation of plate).

Cristellaria pleurostomelloides KARRER, Sitz. k. Akad. Wiss. Wien, vol. 58 (1), 1868 , p. 171 , pl. 4 , fig. 5 .

Psecadium oblongum Franzenau, Glasnik. kr. nar. drutztva God., vol. 6, 1894 , p. 275 , pl. 4 , fig. 52.

Test elongated, more or less irregularly cylindrical, rounded at the base; chambers longer than wide, arranged at the start in a nearly triserial series, later becoming more or less uniserial, but little embracing; sutures depressed, distinct; wall smooth, thick; aperture radiate.

Length of figured specimen $1.20 \mathrm{~mm}$.; breadth $0.40 \mathrm{~mm}$.; thickness $0.35 \mathrm{~mm}$.

Hantken's figure of the present species shows a nearly triserial arrangement of the earlier three chambers, to which are added two uniserial chambers. The chambers are not much elongated and are separated by depressed sutures. Our figured specimen from the Vienna Basin resembles Karrer's Cristellaria pleurostomelloides from Kostej, and has slightly longer chambers than Hantken's species, although there is no important difference between them. 
Psecadium oblongum Franzenau, judging from his figure, is very close to Hantken's species and is provisionally placed under the present species.

Distribution.-Hantken reported the present species from the Eocene of Ofen (Kleinschwabenberg), where he found only one specimen. Karrer noted its occurrence as very rare. We have a single specimen from the Miocene (Tortonian) of the Vienna Basin.

\section{PSEUDOPOLYMORPHINA DIGITATA (d'Orbigny)}

Plate 28, figures $3 a, b$

Polymorphina digitata d'Orbigny, Guerin-Menevilles Cuvier, Iconographie, Mollusques, 1829-43, p. 9, pl. 3, fig. 3.

Polymorphina nodosaria Franke, Danmarks Geol. Unders. II, Raekke, No.46, 1927, p. 35, pl. 3, fig. 18.

Test elongate, cylindrical, rounded at both ends; chambers short, nearly as long as broad, slightly embracing, arranged in an entirely biserial series; sutures but little depressed, distinct; wall smooth; aperture radiate.

Length of figured specimen $1.95 \mathrm{~mm}$; breadth $0.55 \mathrm{~mm}$.; thickness $0.50 \mathrm{~mm}$.

The present species was only figured and not described by d'Orbigny under the name Polymorphina digitata.

Moreover, neither the locality nor geological formation of the species was mentioned, and accordingly there is great difficulty in determining exactly the species. We have several specimens from the Upper Cretaceous of Maastricht, which in every feature resemble d'Orbigny's figure of Polymorphina digitata, and those specimens are provisionally determined as the same as d'Orbigny's species, and one of them is figured.

Pseudopolymorphina digitata of our identifications resembles in some respects $P$. spatulata from the Miocene of Europe, but the latter is more compressed, and its chambers are longer.

Distribution.-We have specimens of the species from the Upper Cretaceous of Maastricht only.

\section{PSEUDOPOLYMORPHINA LEOPOLITANA (Reuss)}

Plate 28, figures $4 a-c$

Polymorphina leopolitana Reuss, Haidinger's Nat. Abhandl., vol. 4, 1851, p. 28 , pl. 4, fig. 11 .

Polymorphina rudis Reuss, Sitz. Akad. Wiss. Wien, vol. 44, pt. 1, 1861 (1862), p. 319 , pl. 3 , figs. $5-8$.

Test elongated, slightly compressed, rounded at the base; chambers inflated, but little embracing, arranged in a nearly biserial series from the beginning, often tending to become uniserial in later development; sutures depressed, distinct; wall smooth; aperture radiate. 
Length 1.10-1.50 mm.; breadth $0.45-0.65 \mathrm{~mm}$; thickness $0.45-$ $0.65 \mathrm{~mm}$.

Pseudopolymorphina leopolitana is evidently related to $P$. soldanii, and they have some characters in common, such as inflated chambers and slightly compressed test.

The present species however, has a much more elongated test, which lacks a triserial arrangement of chambers in its early stages and becomes more or less uniserial in its later stages.

Reuss separated Polymorphina rudis from Pseudopolymorphina leopolitana by its much larger test and its more nearly uniserial arrangement of chambers. As he noted, Polymorphina rudis is very variable, and we can hardly find two specimens quite alike, therefore it is better to unite Reuss's two species cited above.

Distribution.--Reuss's Polymorphina leopolitana is recorded from the mucronata bed of Lemberg (Cretaceous) and his Polymorphina rudis from Cretaceous tuff of Maastricht, in material from which we found several specimens.

The figured specimen is from the chalk marl, Saxon Cement Works, Cambridge, England.

\section{PSEUDOPOLYMORPHINA MENDEZENSIS (White)}

Plate 28, figures 7-9

Polymorphina mendezensis White, Journ. Pal., vol. 2, 1928, p. 213, pl. 29, fig. 14 .

Test compressed, broadly oval to oblong, rounded at the base; chambers rounded, compressed, arranged at first in a nearly triserial series, becoming biserial, each succeeding chamber removed farther from the base; sutures but little depressed, usually distinct; wall thick, smooth; aperture radiate.

Length $0.60-0.75 \mathrm{~mm}$; breadth $0.35-0.45 \mathrm{~mm}$; thickness 0.20 $0.30 \mathrm{~mm}$.

The present species is very variable in its general outline, some broadly rounded at the end consisting of much compressed chambers, the others much narrower at the initial end as each succeeding more or less inflated chamber is removed farther from the base.

In spite of the variable shape of the test, the arrangement of chambers is rather definite, and is always nearly triserial at the start, becoming biserial later. A quinqueloculine arrangement of chambers is lacking in this species.

Distribution.-Pseudopolymorphina mendezensis is very common in the Upper Cretaceous deposits in North America. We have no European specimen representing the present species.

White recorded it from the base of the Mendez to a point a little above the base of the Velasco. It occurs also in our material from the Navarro formation of Texas in various cores. At the clay pit 3 
miles South of Corsicana, Tex., it is very common. We have specimens from the Chipley well in Florida at 2,520 feet.

\section{PSEUDOPOLYMORPHINA SUBNODOSA (Reuss)}

Plate 29, figure 2

Polymorphina subnodosa Reuss, Sitz. Akad. Wiss. Wien, vol. 42, 1860, p. 362, pl. 2, fig. 15 .

Polymorphina nodosaria Reuss, Sitz. Akad. Wiss. Wien, vol. 48, pt. 1, 1863, p. 58, pl. 7, fig. 85.-H. B. Brady, Parker, and Jones, Trans. Linn. Soc., vol. 27,1870 , p. 233 , pl. 40 , figs. $18 a, b$.

Test almost cylindrical, more or less tapering toward the base; chambers inflated, not much embracing, alternating, arranged in a nearly biserial series, becoming uniserial; sutures oblique, depressed; wall smooth; aperture radiate.

Brady, Parker, and Jones put Reuss's Polymorphina subnodosa and $P$. nodosaria together, reserving the latter name because the former does not represent as good a type as that later described under the name which they have adopted. Polymorphina subnodosa was described and figured as well as $P$. nodosaria, and the former has the priority; therefore we keep the specific name "subnodosa" according to the rule of priority.

We have not found any specimen resembling the present species. The above description is written in accordance with Reuss's figure of the species.

Distribution.-The present species is apparently limited to the Tertiary of Europe. Reuss's records are the middle Tertiary of central Germany and the Crag of Antwerp.

\section{PSEUDOPOLYMORPHINA INCERTA (Egger)}

Plate 29, figures $3-5$

Polymorphina incerta EGGER, Neues Jahrb. fur Min., Jahrg. 1857, p. 286, pl. 13, figs. 19-21.

Polymorphina depressa D'Orbigny, Ann. Sci. Nat., vol. 7, 1826, p. 267, No. 26.

Globulina depressa Terquem, Mém. Soc. Géol. France, sér. 3, vol. 2, 1882, p. 131 , pl. 13 (21), figs. 28-30.

Polymorphina (Globulina) depressa Fonnasini, Riv. Ital. Pal., vol. 8, 1902, p. 2 , pl. 1, fig. 8 .

Polymorphina depauperata Reuss, Sitz. Akad. Wiss. Wien, vol. 55, pt. 1, 1867 , p. 89 , pl. 3 , fig. 9 .

Polymorphina amygdaloides Reuss var. lepida Fornasini, Mem. Istit. Accad. Sci. Bologna, ser. 5, vol. 9, 1900-1902 (1902), p. 71, fig. 24 (in text).

Polymorphina subdilatata EgGer, Neues Jahrb. für Min., Jahrg., 1857, p. 286, pl. 13, figs. 30-33.

Polymorphina media EGGER, Neues Jahrb. für Min., Jahrg., 1857, p. 287, pl. 13, figs. 28, 29.

Polymorphina solidula Terquem, Mém. Soc. Géol. France, sér. 3, vol. 1, 1878 , p. 40 , pl. 3 (8), figs. $31 a-33$. 
Test almost equally compressed on both sides, oval, margin rounded; chambers not numerous, usually five or six, compressed, usually almost as broad as long, arranged in a nearly biserial series; sutures not depressed; wall smooth; aperture radiate.

Length, 0.55-0.75 mm.; breadth, 0.45-0.60 mm.; thickness, 0.18$0.25 \mathrm{~mm}$.

Several different names were given by various authors to the different phases of growth of the present species. Globulina depressa, listed by d'Orbigny from the environs of Beauvais in 1826 and figured much later by both Terquem and Fornasini, having four chambers, evidently represents a young stage of the present species. The name, however, can not be used, as the 1826 species was not described or figured until much later.

Polymorphina solidula Terquem is a form having the last chamber added in a slightly abnormal manner. We have such specimens among our collections of Pseudopolymorphina incerta.

Polymorphina depauperata Reuss is undoubtedly the same as Globulina depressa in every respect.

Polymorphina incerta Egger, having the priority among several specific names proposed for the present species, is an adult and more common form.

Polymorphina amygdaloides var. lepida Fornasini, with slightly acute initial end, and Polymorphina subdilatata Egger are forms of the present species having a more or less elongate test.

Polymorphina foveolata was separated by Reuss from Polymorphina depauperata because of its thicker and more or less irregularly oval test and sparsely distributed surface depressions, but such differences appear to us not as important as the other more essential characters which show no real differences between the above two species.

Polymorphina media Egger has an elongate test and is in some respects unlike the present species, but we think it is better to place it as within the range of variation of Pseudopolymorphina incerta.

Distribution.- One of the most common species distributed widely in the European younger Tertiary deposits. We have the species from the following localities:

Recent.-Italy, shore sand of Rimini on the Adriatic.

Miocene--France, Helvetien, Pontlevoy; Aquitanien superieur, St. Avit, near Mont de Marsen; La Brede, Larriey; Burdigalien superieur, Merignac (Gironde); Burdigalien inferieur, Dax; Moulin de l'Eglise, Saucats; Le Coquillat, Leognan. Hungary, Tortonian, Varpolata.

Eocene.-France, Lutetien, Orbitolites bed, Grignon. England, Bracklesham bed XVII, White Cliff Bay, Isle of Wight. 
Genus PALEOPOLYMORPHINA Cushman and Ozawa, new genus

Test with the early chambers spiral, later ones becoming biserial. Genotype.-P. pleurostomelloides (Franke).

\title{
PALEOPOLYMORPHINA PLEUROSTOMELLOIDES (Franke)
}

\author{
Plate 28, figures $5 a, b$
}

Polymorphina pleurostomelloides Franke, Abhandl. d. preuss. geol. Landesanstalt, vol. 3,1928 , p. 121, pl. 11, fig. 11 .

Test small, more or less cylindrical, tapering toward the initial end; chambers inflated, oval, but little embracing, alternating, arranged in an entirely biserial series, each succeeding chamber much farther removed from the base; sutures oblique, much depressed, distinct; wall smooth; aperture radiate.

The present species quite recently has been described by Franke from the lower Cenomanian marl of Tecklenburg, a locality from which we obtained foraminiferal material from the original author and found three specimens. They are very similar to Pleurostomella, excepting for the radiate aperture. Its development is evidently a biserial one from a spiral ancestry, and as such we have erected a new genus for it and the following species.

Distribution.-Germany, lower Cenomanian, Tecklenburg, Westphalia, near the brickyard of Hollenberg, where it is not rare.

\section{PALEOPOLYMORPHINA GAULTINA (Berthelin)}

Plate 28, figures $6 a, b$

Polymorphina gaultina Berthelin, Mém. Soc. Géol. France, sér. 3, vol. 1, 1880 , p. 58 , pl. 4 , figs. $19 a-c$.

Test small, more or less compressed, fusiform, acute at both ends; chambers $f 6^{\prime} \mathrm{w}$, the lase two much larger than the earlier ones, embracing, arranged in a biserial series, each succeeding chamber removed from the base; sutures but little depressed, distinct; wall smooth; aperture radiate.

Paleopolymorphina gaultina is one of the smallest species among the Polymorphinidae. The test is generally composed of five chambers, of which the last two are much enlarged. It is a well-defined species and can be easily distinguished from any other.

Distribution.-Berthelin described it from the Lower Cretaceous (Albian) of France. We have several specimens from the Gault of Folkestone, England. 


\section{Genus POLYMORPHINA d'Orbigny, 1826}

\section{POLYMORPHINA BURDIGALENSIS d'Orbigny}

Plate 29, figures $7 a-c$

Polymorphina burdigalensis D'ORBIGNy, Ann. Sci. Nat., vol. 7, 1826, p. 265, No. 2; model No. 29.-H. B. Brady, Parker, and Jones, Trans. Linn. Soc., vol. 27, 1870, p. 224, pl. 39, figs. $9 a, b .-$ Cushman and Ozawa, Contr. Cushman Lab. Foram. Res., vol. 4, pt. 1, 1928, p. 16, pl. 2, fig. 10.-Ozawa, Contr. Cushman Lab. Foram. Res., vol. 5, pt. 2, 1929 , p. 35 , pl. 6, figs. 1-3.

Polymorphina burdigalensis D'ORBIGny var. lequilensis Fornasini, Mem. Istit. Bologna Acad. Sci., ser. 5, vol. 9 (1900-1902), p. 73, fig. 26.

Test fusiform to oblong, more or less flattened on one side, unsymmetrically convex on the other; chambers elongate, more embracing on the flattened side, arranged in an almost biserial series from the start; sutures scarcely depressed, distinct; wall smooth, translucent; aperture radiate.

Length of figured specimen $0.75 \mathrm{~mm}$.; breadth $0.40 \mathrm{~mm}$.; thickness $0.25 \mathrm{~mm}$.

Ozawa found that d'Orbigny's original specimen deposited in the paleontological department, Museum of Natural History, Jardin des Plantes in Paris, is lost, and the species has been neither figured nor described by d'Orbigny; therefore the only reference having any authority is a plaster model. Brady, Parker, and Jones figured a model of Polymorphina burdigalensis in their monograph, but as far as the figures are concerned their model is different from that in the Cushman Laboratory, because those figures are the reverse of that form shown by this model; but all models of Polymorphina burdigalensis, including that in the British Museum of Natural History, which was examined, are just the same as this. Apparently this reversal came in the drawing of the figures, a similar reversal being shown in other species in Brady, Parker, and Jones' monograph. According to the Tableaux Méthodique, d'Orbigny's specimen was obtained from the Miocene in the environs of Bordeaux. We have examined much material from the same locality, as well as from Dax, and only one specimen somewhat resembling the model was found. The specimen figured here is just the same as Polymorphina burdigalensis, at least in the degree of embracing of the elongate chambers and an unequal compression on each side of the test, although the arrangement of chambers is not as regular as shown by the model, which should be considered to be somewhat coventionalized.

Fornasini's Polymorphina burdigalensis var. lequilensis, obtained from Lequile, is almost the same as ours.

Distribution.-The locality of our figured specimen is Miocene (Burdigalien inferieur), Moulin de l'Eglise, Saucats, (Gironde), France. 
Plate 29, figures $8 a, b$

Test compressed, oblong, greatest breadth in the upper half tapering toward the acute base, periphery rounded; chambers elon gated, arranged at first in a more or less sigmoid series becoming regularly biserial; sutures slightly depressed, distinct; wall smooth, thin, transparent; aperture radiate.

Length of holotype $1.25 \mathrm{~mm}$.; breadth $0.60 \mathrm{~mm}$.; thickness $0.30 \mathrm{~mm}$. Holotype--(Cushman Coll. No. 9,867.) Recent, off Tripoli.

The early chambers of the species are sigmoidally arranged, but the later ones are regularly biserial and alternating, sometimes becoming very irregular and spreading.

The species is named for Prof. C. Fornasini of Bologna, Italy.

\section{POLYMORPHINA INCAVATA Stache}

Plate 29, figures $9 a, b$

Polymorphina incavata Stache, Novara Exped., Geol. Theil 1, 1864, p. 260, pl. 24, figs. $7 a, b$.

Polymorphina dispar Stache, Novara Exped., Geol. Theil 1, 1864, p. 261, pl. 24 , figs. $8 a, b$.

Test more or less compressed, elongated, rounded at the base; chambers twice as long as wide, more or less inflated, not much embracing, arranged in a biserial series; sutures slightly depressed, distinct; wall smooth; aperture radiate.

We have no specimen which we can identify with the present species, and the above description is given in accord with the original figures. Stache's $P$. dispar is very similar to the present species. It may be a young specimen. It seems to be known only from the Tertiary, Upper Eocene, at Whaingaroa Port, New Zealand.

\section{POLYMORPHINA SUBRHOMBICA Reuss}

\section{Plate 30 , figures $1-3$}

Polymorphina subrhombica Reuss, Sitz. Akad. Wiss. Wien, vol. 44, pt. 1, 1861 (1862), p. 339, pl. 7, fig. 3 .

Test compressed, rhombic (young) to subrhomboidal (adult), symmetrical, margin angular; chambers rather broad, not much embracing, alternating; wall smooth, thick; sutures not depressed, but distinct; aperture radiate.

Maximum length $2.60 \mathrm{~mm}$; 作eadth $1.30 \mathrm{~mm}$.; thickness $0.50 \mathrm{~mm}$.

The present species has fairly large dimensions and even a few chambered specimen attains 1 millimeter in length. It has but a slight resemblance to Polymorphina complanata, with which it has been generally considered to be identical. The narrow elliptical end view is enough to separate the present species from any other of the 
known species of Polymorphina having the chambers arranged in an entirely biserial manner.

Distribution.-Reuss first described Polymorphina subrhombica from the Upper Cretaceous (?) (Eocene (?)) of New Jersey, where it is rather common in the Eocene formation, and from which we have several specimens. The formation formerly supposed to be Cretaceous in New Jersey is probably Eocene.

\section{POLYMORPHINA ACULEATA d'Orbigny}

Plate 30, figure 4

Polymorphina aculeata D'Orbigny, Ann. Sci. Nat., vol. 7, 1826, p. 265, No. 5.-Fornasini, Riv. Ital. Pal., vol. 8,1902 , p. 1, pl. 1, fig. 1 .

Test compressed, elongate, margins almost parallel, acute at both ends, initial end with a spine; chambers compressed, elongate, alternating; sutures but little depressed, distinct; wall ornamented with fine costae, interrupted at the sutures; aperture produced, radiate.

Polymorphina aculeata, listed by d'Orbigny but not figured or described until 1902 by Fornasini, is a well-characterized species reported from the environs of Paris. We have examined material from the Paris Basin, but we could not find any specimen like this. The above description is based on Fornasini's figure.

Distribution.-Known only from the Eocene of the Paris Basin.

POLYMORPHINA LONGISTRIATA Cushman and Ozawa, new species

Plate 30 , figure 5

Polymorphina complanata (D'OrBigny) var. striata Burrows and Holland, Proc. Geol. Assoc., vol. 15, 1897, p. 46, pl. 2, fig. 15.

Test elongate, rhomboidal, compressed, almost symmetrical; chambers compressed, alternating, arranged in an entirely biserial series; sutures slightly depressed, distinct; wall ornamented by longitudinal costae interrupted at the sutures; aperture radiate.

We have examined material which we collected from the Thanet beds of Pegwell Bay, but we did not find any specimen like Polymorphina complanata var. striata described by Burrows and Holland. This seems to be quite distinct from any described species. It is evidently related to Polymorphina complanata d'Orbigny in its much specialized biserial arrangement of chambers, but it is not only ornamented but the test is also much elongated and its chambers are much broader than those of Polymorphina complanata.

A new specific name "longistriata" is proposed.

Its nearest ally seems to be Polymorphina advena Cushman, from which it is separated by its more elongate, angular test, and coarser ornamentation.

Distribution.-The only known record is from the Thanet beds of Pegwell Bay in England. 


\section{POLYMORPHINA PARALLELA Millett}

Plate 30, figures $6 a, b$

Polymorphina regularis var. parallela Mrllett, Trans. Roy. Geol. Soc. Cornwall, 1894, pp. 4, 7 (list), pl., figs. 5, $6 a, b$.

Test compressed, oblong, margins nearly parallel; chambers elongate, compressed, alternating; sutures not depressed; wall smooth, translucent; aperture radiate.

The present species is recorded by Millett under the name of Polymorphina regularis var. parallela. His description runs as follows:

"This variety has the characters both of $P$. regularis and $P$. frondiformis. It differs from the former in having the lateral faces parallel, and from the latter in the fact that the sutures do but rarely reach the central line of the test, leaving a clear space from the oral to the aboral ends."

It is quite distinct from Sigmomorpha regularis in its arrangement of sutures. It resembles in some features Polymorphina frondea, but the latter has the periphery with raised margins.

Distribution.-Millett's specimens are from the Pliocene of St. Erth, England.

\section{POLYMORPHINA ALLENI Cushman and Ozawa, new species}

Plate 30, figures $7 a, b$

Polymorphina complanata Heron-Allen and Earland, Journ. Roy. Micr. Soc., 1909, p. 432 , pl. 17, figs. 3-5.

Test broadly oval, much compressed, symmetrical; chambers curved, elongate, cylindrical, alternating, each succeeding chamber slightly removed from the base; sutures depressed, distinct, uniformly curved; wall rather thin, translucent, smooth; aperture radiate.

Length of holotype $0.70 \mathrm{~mm}$; breadth $0.37 \mathrm{~mm}$; thickness 0.12 $\mathrm{mm}$.

Holotype.-(Cushman Coll. No. 11777.) From Eocene, Bracklesham bed XVIII, White Cliff Bay, Isle of Wight, England.

Heron-Allen and Earland described and figured from Selsey a pretty biserial specimen of Polymorphina under the name of $P$. complanata d'Orbigny. We have a specimen from the Bracklesham bed XVIII, White Cliff Bay of Isle of Wight, which in every respect coincides with Heron-Allen and Earland's species. This is quite distinct from Polymorphina complanata from the Vienna Basin in the uniform, strongly curved, cylindrical chambers, all of which come down much farther toward the base than in $P$. complanata.

To the present species a new specific name alleni is given for Edward Heron-Allen. 
Plate 30 , figures $8 a, b$

Polymorphina cushmani Plummer, Bull. 2644, Univ. Texas, 1927, p. 125, pl. 6 , fig. 9 ; pl. 15 , figs. $1 a-c$.

Test compressed, oblong, broadest at the upper half, rhomboidal in end view, margins angular but not carinate; chambers elongate, alternating in an entirely biserial series; sutures not depressed, straight, often thickened and obscured; wall thick, ornamented in the middle part of the broad faces with raised beads arranged longitudinally from the aperture to the initial end or not more than four, strong, broken costae developing independently of the sutures; aperture radiate.

Maximum length $2.60 \mathrm{~mm}$.; breadth $1.30 \mathrm{~mm}$.; thickness $0.60 \mathrm{~mm}$.

Polymorphina cushmani is one of the best defined species of the genus. Its straight sutures and peculiar ornamentation are the special features that will separate it from the species related to it.

Distribution.-This species seems to be limited to the lower Eocene, Midway, of the Texas region. Mrs. Plummer describes it from the base of a high bluff on west side of Colorado River between the TravisBastrop County line and the mouth of Dry Creek (Bastrop quadrangle), Tex., and $5 \frac{1}{4}$ miles due south and very slightly west of Littig, where the 440 -foot contour cuts a northeast-southwest road (Bastrop quadrangle), Texas. The specimen here figured is from the station near Littig, kindly sent us by Mrs. Plummer. We also have typical specimens from the Midway of Texas in our collection from other Texas localities.

Mrs. Plummer's notes on the occurrence of this species are given here:

In the Midway formation $P$. cushmani is most frequent in the glauconitic sands and clays in the upper part of the transition zone, which in the belt of outcrop northeast of the Mexia area is marked by phosphatic nodules and southwest of this same area by the abundance of Venericardia bulla. In some outcropping clays it is of sufficient abundance to be detected with the aid of a hand lens. Because no other formation in the Texas geologic section has yielded a compressed Polymorphine test bearing strong longitudinal markings, $P$. cushmani becomes very useful as a Midway signpost. The underlying Navarro formation carries very rarely a somewhat similar large species that is much smoother and possesses fewer chambers in its fullest development.

\section{POLYMORPHINA COMPLANATA d'Orbigny}

Plate 30, figures $9 a, b$

Polymorphina complanata D'Orbigny, Foram. Foss. Bass. Tert. Vienne, 1846, p. 234, pl. 13, figs. 25-30.-H. B. Brady, Parker, and Jones, Trans. Linn. Soc., vol. 27,1870 , p. 230 , pl. 40 , figs. $14 a, b$; woodcuts $f-j$.

Test rhombic in outline, much compressed, greatest breadth above the middle, acute toward the initial end; chambers elongate, slender, 
compressed, arranged in a regular biserial series, alternating almost equally upon the two sides, slightly embracing, each succeeding chamber removed farther from the base; sutures slightly depressed, distinct; wall smooth; aperture radiate.

Maximum length $1.25 \mathrm{~mm}$.; breadth $0.95 \mathrm{~mm}$.; thickness $0.15 \mathrm{~mm}$.

Polymorphina complanata is highly specialized and can be easily distinguished from any other described species by its much compressed and rhombic test. The arrangement of the chambers is also very regular and entirely biserial, and a Guttulina-like stage is skipped in this species.

Many forms are recorded as Polymorphina complanata from various parts of the world, but are all different from the species described by d'Orbigny from the Vienna Basin.

Distribution.-The present species is only known from the Tortonian, Amphistegina marl, at Grunes Kreuz, Nussdorf, near Vienna, where it is fairly common. Ozawa collected more than 50 specimens from this locality. D'Orbigny reported its occurrence in the Tortonian clay of Baden, but there is no original or paratype specimen of the present species from Baden, and Ozawa could not find any specimen like the present one in all the material he collected and prepared from that locality.

\section{POLYMORPHINA ADVENA Cushman}

Plate 30, figures $10 a, b$

Polymorphina advena Cushman, U. S. Geol. Survey Prof. Paper 129-F, 1922, p. 132, pl. 31, fig. 4; Contr. Cushman Lab. Foram. Res., vol. 5, 1929 , p. 41 , pl. 7 , fig. 5 .

Test much compressed, broadly ovate; chambers numerous, elongate, alternating, much the broadest near the peripheral end; sutures slightly depressed, very oblique; surface ornamented with numerous fine longitudinal costae, except the last-formed one or two chambers, which are smooth, at least at the apertural end; aperture radiate.

Length $0.40-0.65 \mathrm{~mm}$; breadth $0.22-0.30 \mathrm{~mm}$.; thickness $0.05-$ $0.06 \mathrm{~mm}$.

Type specimen from the Lower Oligocene, Mint Spring marl, Mint Spring Bayou, Vicksburg, Miss. It is also known from the Byram marl of Byram, Miss.

This species is an unusual one for this genus, appearing much more like a Bolivina, but it has the characteristic aperture of Polymorphina. It is perhaps most closely related to Polymorphina complanata d'Orbigny.

POLYMORPHINA FRONDEA (Cushman)

Plate 30, figures $11 a, b$

Bolivina frondea Cushman, U. S. Geol. Survey Prof. Paper 129-F, 1922, p. 126, pl. 29, fig. 3; Prof. Paper 133, 1923, p. 20.

Polymorphina frondea Cushman, Contr. Cushman Lab. Foram. Res., vol. 5, 1929, p. 41. 
Test compressed, of uniform thickness, the broad sides nearly parallel, oblong, broadest above the middle, acuminate toward the initial end, margins with a raised rim; chambers compressed, elongated, alternating; sutures depressed, distinct; wall smooth, often with obscure fine costae; aperture radiate.

Length $0.50-0.65 \mathrm{~mm}$; breadth $0.30-0.40 \mathrm{~mm}$.; thickness $0.04-$ $0.05 \mathrm{~mm}$.

Polymorphina frondea is one of the most clearly marked species of Polymorphina. Its raised margins are very characteristic, and no other known species has such margins. Otherwise, it is closely related to Polymorphina advena, which is always ornamented on its surface and has a rounded periphery.

Distribution.-The species is characteristic of the lower Oligocene of the Coastal Plain region of the United States; Byram marl, Byram, Miss.; Glendon limestone, below waterfall in Glass Bayou, Vicksburg, Miss.; west bank of Conecuh River at McGowan's Bridge, about 1 mile below the mouth of the Sepulga River, Ala.; Marianna limestone, bluff east of small branch about $1 \frac{1}{2}$ miles northeast of Brandon, Miss.; Mint Spring marl, Chickasawhay River, $1 \frac{1}{4}$ miles northwest of mouth of Limestone Creek, 4 miles northwest of Waynesboro, and $1 \frac{112}{2}$ miles southwest of Boice, Miss.; Red Bluff clay, St. Stephen's Bluff, right bank of Tombigbee River, about 9 miles above Jackson, Ala.

\section{POLYMORPHINA CHARLOTTENSIS Cushman}

Plate 31, figures 1-6

Polymorphina charlottensis Cushman, Contr. Cushman Lab. Foram. Res., vol. 1, 1925, p. 41, pl. 6, fig. 9.-Cushman and Ozawa, Jap. Journ. Geol. and Geogr., vol. 6, 1929, p. 72, pl. 13, fig. 8; pl. 15, figs. 11, 12; pl. 16, fig. 1.

Polymorphina compressa Cushman, Bull. 71, U. S. Nat. Mus., pt. 3, 1913, p. 89 , pl. 40 , fig. 3 .

Polymorphina complanata BAGG (not d'Orbigny), Bull. 513, U. S. Geol. Survey, 1912, p. 69 , pl. 20, figs. 13, 14.

Polymorphina biserialis Galloway and Wissler, Journ. Pal., vol. 1, 1927, p. 53 , pl. 9 , fig. 4 .

Polymorphina elongata Galloway and Wissler, Journ. Pal., vol. 1, 1927, p. 54 , pl. 9 , fig. 7 .

Test elongate, more or less compressed, tapering slightly from the broadly rounded initial end, edges more or less angular; chambers compressed, not much elongated, arranged at first in a clockwise, sigmoid series in the microspheric form, but in an almost alternating biserial series in the megalospheric form, each succeeding chamber removed much farther from the base; sutures not depressed, generally limbate and distinct; wall smooth, translucent; aperture radiate.

Maximum length, $3.10 \mathrm{~mm}$.; breadth, $0.85 \mathrm{~mm}$.; thickness; $0.30 \mathrm{~mm}$. Polymorphina charlotiensis is generally very large, attaining 3 millimeters in length. Bagg described and figured the present spe- 
cies under the name Polymorphina complanata d'Orbigny, but the two have almost no features in common excepting the alternating chambers.

Cushman described and figured the microspheric form of the present species from British Columbia.

To the same form Galloway and Wissler later gave the name Polymorphina elongata, which is considered by them to be the same as Bagg's Polymorphina compressa, but Bagg's P. compressa has depressed sutures and more rounded chambers, the characteristies of Pseudopolymorphina, and is quite different from Galloway and Wissler's $P$. elongata. Moreover, $P$. elongata is preoccupied by Fornasini in 1902.

Polymorphina biserialis Galloway and Wissler, reported from the Pliocene of Timms Point, Calif., is evidently a full-grown specimen of the present species.

Distribution.-Polymorphina charlottensis is a species limited to the Pacific as far as known. It is only known from the late Tertiary and as a Recent species. We have specimens from the following localities:

Recent.-Queen Charlotte Sound, British Columbia, 25 fathoms. Albatross D 4825, D 4826, D 4878 off Japan, 84-114 fathoms.

Pleistocene.-Lomita Quarry, Palos Verdes Hills, California.

Pliocene.-Timms Point, San Pedro, California. Natsukawa, Province of Echigo, Japan.

\section{POLYMORPHINA LINGULATA Stache}

Plate 31 , figures $7 a, b$

Polymorphina lingulata Stache, Novara Exped., Geol. Theil, vol. 1, Abt. 2, 1864, p. 255, pl. 24, fig. $1 a, b$.

Polymorphina sacculus Stache, Novara Exped., Geol. Theil, vol. 1, Abt. 2, 1864, p. 259, pl. 24, fig. $6 a, b$.

Polymorphina pernaeformis Stache, Novara Exped., Geol. Theil, vol. 1, Abt.2, 1864, p. 256, pl. 24, fig. $2 a, b$.

Polymorphina gigantea Stache, Novara Exped., Geol. Theil, vol. 1, Abt. 2, 1864, p. 262, pl. 24, fig. $9 a, b$.

Polymorphina cognata Stache, Novara Exped., Geol. Theil, vol. 1, Abt. 2. 1864, p. 257, pl. 24, fig. $3 a, b$.

Polymorphina contorta Stache, Novara Exped., Geol. Theil, vol. 1, Abt. 2, 1864 , p. 257 , pl. 24 , fig. $4 a, b$.

Polymorphina marsupium Stache, Novara Exped., Geol. Theil, vol. 1, Abt. 2, 1864 , p. 258 , pl. 24 , fig. 5 , b.-Chapman, New Zealand Geol. Surv., Pal. Bull. No. 11, 1926, p. 68 , pl. 5, fig. 5 .

Polymorphina regularis MÜnster var. lingulata Chapman, New Zealand Geol. Surv., Pal. Bull. No. 11, 1926, p. 67, pl. 5, figs. 1, 3, 4, 6.

Polymorphina regularis MÜnster var. pernaeformis Chapman, New Zealand Geol. Surv. Pal. Bull. No. 11, 1926, p. 67, pl. 5, fig. 2.

Polymorphina regularis Chapman, New Zealand Geol. Surv., Pal. Bull. No. $11 ; 1926$, p. 67 , pl. 5, fig. $9 a, b$.

Test compressed, oval (young) to oblong (adult), tapering toward both ends; chambers elongated, alternating, arranged in a nearly 
biserial series from the start; sutures not depressed, limbate, distinct; wall smooth; aperture radiate.

Ozawa examined the original specimens of $P$. lingulata, $P$. pernaeformis, $P$. cognata, $P$. contorta, $P$. marsupium, and $P$. sacculum deposited in the department of geology and paleontology, Museum of Natural History of Vienna, and is convinced that the difference among these species is not more than the range of variation of individuals of one species.

We have no specimens like the present species. It closely resembles $P$. charlottensis found in the Pacific, but the test is much broader, consisting of elongated chambers. Polymorphina subrhombica from the lower Eocene of New Jersey appears to be very close to Polymorphina lingulata, but it has straight sutures, wider chambers and a more compressed test.

Distribution.-Stache's species were from the Tertiary of New Zealand.

\section{POLYMORPHINA SCHLUMBERGERI Cushman and Ozawa, new species}

Plate 31 , figures $8 a, b$

Test compressed, fusiform in outline, rather obtuse at both ends, margin even, periphery rounded; chambers compressed, elongated, arranged at first in a contraclockwise, sigmoid series, later becoming regularly biserial; sutures not depressed, distinct; wall smooth, rather thick, polished; aperture radiate.

Length of holotype $0.90 \mathrm{~mm}$.; breadth $0.50 \mathrm{~mm}$.; thickness $0.20 \mathrm{~mm}$. Holotype.-(Cushman Coll. No. 11791.) From the Miocene, Aquitanian superieur, St. Avit, near Mont de Marsan, France.

In its arrangement of chambers it is very similar to Polymorphina fornasinii, but it has a rather obtuse end, the sutures not depressed, and the later chambers more elongate.

\section{POLYMORPHINA HOWCHINI Cushman and Ozawa, new species}

\section{Plate 31, figures $9 a, b$}

Test elongated, compressed, broadly rounded at the base, more or less tapering toward the obtuse apertural end; periphery rounded; chambers, much longer than broad, slightly inflated, overlapping, alternating in a biserial series; sutures very little depressed, not very distinct; wall thick, partly ornamented by numerous fine costae better developed near the base; aperture large, radiate.

Length of holotype $2 \mathrm{~mm}$.; breadth $1.05 \mathrm{~mm}$.; thickness $0.45 \mathrm{~mm}$. Holotype.-(Cushman Coll. No. 9771.) From the Lower Pliocene, McDonalds, Muddy Creek, Hamilton, Victoria, Australia.

The present species is fairly large, and in general outline it resembles Polymorphina frondiformis from the Crag of England, but it is much 
thicker and the numerous costae, although only partly developed, are much finer. It is named for Rev. W. Howchin, of Australia.

\section{POLYMORPHINA FRONDIFORMIS Searles Wood}

Plate 31 , figures $10 a, b$

Polymorphina frondiformis Searles Wood, in Morris, Catal. Brit. Fossils, 1843, p. 62.-Jones, Parker, and H. B. Brady, Crag. Foram., Pal. Soc., vol. 19, 1866, App. i, ii (footnotes), pl. 1, figs. 62, 63, 69.-H. B. Brady, Parker, and Jones, Trans. Linn. Soc., vol. 27, 1870, p. 241, pl. 41, figs. $33 a-c$.-Jones, Foram. Crag., pt. 3, 1896, p. 271, pl. 1, figs. 62,$63 ;$ pl. 4 , figs. $11-14$.

Test elongate, oval, greatest breadth above the middle, more acute toward the base than the apertural end; chambers elongate, compressed, not much embracing, arranged in an entirely biserial series, each succeeding chamber removed much farther from the base; wall rather thick, ornamented with irregular, rough, longitudinal costae, interrupted at the sutures, sometimes almost smooth; sutures but little depressed, not very distinct; aperture radiate.

Our largest specimen measures, length $3.40 \mathrm{~mm}$.; breadth $1.60 \mathrm{~mm}$.; thickness $0.30 \mathrm{~mm}$.

Polymorphina frondiformis with generally large dimensions is one of the most specialized and well-defined species of the genus. Its surface ornamentation is not definite, but is usually present to a greater or less extent. It consists of circular or oval beads or of more or less interrupted costae distributed unequally in a longitudinal direction over the flat sides of the test.

Distribution.-The present species appears to be limited to the Crag in England, in which it is rather common. Searles Wood first reported it from the Crag at Sutton, near Colchester, where our specimens were also obtained. Brady, Parker, and Jones record it from the Coralline Crag of East Anglia.

\section{Genus SIGMOMORPHINA Cushman and Ozawa, 1928}

\section{SIGMOMORPHINA NYSTI (Reuss)}

Plate 32 , figures $1 a, b$

Polymorphina regularis Münster var. nysti Reuss, Bull. Acad. Roy. Sci. Belg., sér. 2, vol. 15, 1863, p. 152, pl. 3, fig. 42.

Test compressed, lanceolate, greatest breadth in the upper half, tapering toward the base, margin angulate; chambers elongated, arranged in an open, clockwise, sigmoid series, each succeeding chamber removed much farther from the base; sutures not depressed, almost straight, distinct; wall smooth; aperture radiate.

Length of figured specimen $1.15 \mathrm{~mm}$.; breadth $0.45 \mathrm{~mm}$.; thickness $0.20 \mathrm{~mm}$. 
The present species is described by Reuss as a variety of Polymorphina regularis and the varietal name "nysti" is only used in the explanation of the figure. It is related to the German Oligocene species $S$. regularis in some features, but the present species has shorter and noninflated chambers and the test is narrower with straight sides.

Distribution.-Reuss recorded this species from the Crag of Antwerp. We have found it in the Miocene, Burdigalien inferieur, Le Coquillat, Leognan, France, a specimen from this locality being figured here.

\section{SIGMOMORPHINA JACKSONENSIS (Cushman)}

Plate 32 , figures $2 a, b$

Polymorphina jacksonensis Cushman, Contr. Cushman Lab. Foram. Res., vol. 2, 1926, p. 35 , pl. 5, figs. $5 a, b$.

Polymorphina compressa Nuttall, Quart. Journ. Geol. Soc., vol. 84, 1928, p. 93 , pl. 6 , figs. 18,19 .

Test broad and compressed, periphery broadly rounded, apertural end narrowed to a slightly produced aperture; chambers elongate, slightly inflated, embracing, arranged in a contraclockwise, sigmoid series, each succeeding chamber removed farther from the base; sutures very slightly depressed, distinct, almost straight; wall thick, smooth; aperture radiate.

Maximum length $1.10 \mathrm{~mm}$.; breadth $0.65 \mathrm{~mm}$; thickness $0.25 \mathrm{~mm}$.

Sigmomorphina jacksonensis more or less resembles S. regularis in some features, but the latter has more inflated chambers arranged in a clockwise, sigmoid series.

Distribution.-The type locality for this species is near Blue Springs, Jackson County, Fla. The other localities of our specimens are as follows: Upper Eocene, Jackson, Miss. Jackson, west bank of Chickasawhay River, 1 1/2 miles south of Shubuta, Wayne County, Ala.; on small stream entering Conecuh River, NE. 1/4 sec. 6, T. 3 N., R. 15 E., 1 mile east of Beck, Covington County; about $3 \frac{1}{2}$ miles southeast of Cullomburg, road from Bladen Springs to Millry. Cocoa sand, Cocoa post office. Ocala limestone, branch at road in sec. 7, T. 6 N., R. 6 E., 11/2 miles southwest of Perdue Hill, Monroe County, Ala. Barnwell sand, Barnwell County, S. C. Claiborne, Lisbon formation, 1 mile north of Watubbee Station, Clarke County, Miss. It occurs at numerous other Claiborne localities not listed here. Trinidad, Mount Moriah beds, Vistabella quarry.

SIGMOMORPHINA JACKSONENSIS (Cushman) var. COSTIFERA (Cushman)

Plate 32 , figurse $3 a, b$

Polymorphina jacksonensis Cushman var. costifera Cushman, Contr. Cushman Lab. Foram. Res., vol. 2, 1926, p. 35.

Variety differing from the typical in the ornamentation of the test, which in the variety has several rounded longitudinal costae on the 
basal portion of the test, sometimes covering a large portion of the surface. As a rule the variety and the typical form do not occur together, although both occur at Jackson, Miss., and at a station 1 mile east of Beck, Covington County, Ala.

Maximum length $1.20 \mathrm{~mm}$; breadth $0.50 \mathrm{~mm}$.; thickness $0.13 \mathrm{~mm}$.

Distribution. - The localities of the variety in our collection are all from the upper Eocene. Jackson formation, Mississippi, roadside on hill above pumping station, Jackson; Bluff on Garlands Creek, about 5 miles northeast of Shubuta, Clarke County; large ravine about 1 mile south of Yazoo City, Yazoo County. Alabama, east bank of Sepulga River, about 4 miles northeast of Brooklyn, Conecuh County; road from Perdue Hill to Claiborne, Monroe County; bank of small stream entering Conecuh River, northeast $1 / 4$ sec. 6, T. $3 \mathrm{~N}$, R. 15 E., 1 mile east of Beck, Covington County. Georgia, Rich Hill, Crawford County, 6 miles southeast of Roberta. Florida, road near Blue Springs, Jackson County. South Carolina, Barnwell sand, Barnwell County.

A few specimens evidently of this variety are from the Gosport sand of the Claiborne, near Claiborne, Ala.

\section{SIGMOMORPHINA CHAPMANI (Heron-Allen and Earland)}

Plate 32 , figures 4,5

Polymorphina chapmani Heron-Allen and Earland, Journ. Roy. Micr. Soc., 1924, p. 163, pl. 10, figs. 60-63.

"Test compressed, sharp at the marginal edges; thickest at a point between the edge and the median line, which is somewhat depressed; consisting of 4 to 6 pairs of chambers, rapidly increasing in size, arranged alternately on each side of the median line. The whole shell has a spiral twist to the extent of about a quarter of a convolution on this median axis. Sutures flush and obscure but thick. Aperture typical but inconspicuous. Not infrequent and one of the most striking forms in the deposits. Its structure is very obscure, but it appears to represent a thin and sharply carinate and twisted form of P. humboldti Bornemann. Length 0.80-1.50 mm."

Distribution.-Janjukian, "Filter quarry," Batesford, Victoria, Australia.

Sigmomorphina chapmani is one of the best defined species among the genus. We have examined material from Filter quarry, but no specimen of this species was found; therefore Heron-Allen and Earland's description is cited above, and their figures are copied here.

SIGMOMORPHINA NUTTALLI Cushman and Ozawa, new species

Plate 32, figures $6 a, b$

Test compressed, more or less inflated in the median, longitudinal area, rounded at the hase, periphery somewhat acutely edged; 
chambers elongated, arranged in a clockwise, sigmoid series, each succeeding chamber much farther removed from the base; sutures not depressed, distinct; wall smooth; aperture radiate.

Length of holotype $0.90 \mathrm{~mm}$.; breadth $0.45 \mathrm{~mm}$.; thickness 0.20 $\mathrm{mm}$.

Holotype.-(Cushman Coll. No. 11799.) From the Eocene, Mount Moriah beds, yellow sandy clay overlying orbitoidal limestone, Vistabella quarry, Trinidad, British West Indies.

In general features it is very similar to $S$. jacksonensis, but the sigmoid arrangement of chambers in the present species is clockwise, while in S. jacksonensis, it is contraclockwise. We have no specimens of $S$. jacksonensis having a clockwise arrangement of chambers. The species from Trinidad, although they are represented by but few specimens, are clockwise. Therefore the Trinidad specimens are separated from the Jackson species, and the specific name nuttalli is given for Dr. W. L. F. Nuttall who has described many species from Trinidad.

\section{SIGMOMORPHINA FLINTII (Cushman)}

Plate 32, figures $7 a-c$

Polymorphina flintii Cushman, Bull. 104, U. S. Nat. Mus., pt. 4, 1923, p. 155, pl. 40 , fig. 10.

Test oval or somewhat rhomboidal, compressed, margin more or less angulate; chambers elongated, slightly inflated, arranged in a clockwise, sigmoid series, each succeeding chamber removed farther from the base; sutures distinct, but very slightly depressed; wall smooth, thick; aperture radiate.

Maximum length, $2.50 \mathrm{~mm}$.; breadth, $1.35 \mathrm{~mm}$.; thickness, $0.55 \mathrm{~mm}$.

This is a large well-characterized species in its more or less compressed test, consisting of elongated chambers arranged in a clockwise sigmoid series.

Distribution.-This species occurs at a large number of Albatross stations off the eastern coast of the United States at depths ranging from 56-72 fathoms. Somewhat similar specimens occur in the upper Pliocene of Natsukawa, Province of Echigo, Japan, and in the Miocene, Janjukian, of Filter quarry, Batesford, Victoria, Australia.

\section{SIGMOMORPHINA PSEUDOREGULARIS Cushman and Thomas}

Plate 32, figures $8 a-c$

Sigmomorpha (Sigmomorphina) pseudoregularis Cushman and Thomas, Journ. Pal., vol. 3, 1929, p. 178, pl. 23, figs. $5 a-c$.

Polymorphina regularis Stadnichenko (not von Münster), Journ. Pal., vol. 1, 1927, p. 231, pl. 38 , figs. $18,19$.

Test large; length about twice the width and thickness a little more than half the width; median longitudinal ridge on both sides with sutures sloping backward, both right and left sets beginning at 
right side of ridge, the left set crossing the ridge and bending in a gentle curve backward, while those on the right begin at the right of the ridge and extend backward in a more nearly direct fashion, both sets reaching the periphery and giving the shell only a semiequitant appearance, the two sides so nearly equal as to give a bilateral symmetry; aperture round, radiate, the apertural end showing four chambers.

Length of holotype, $0.70 \mathrm{~mm}$; width, $0.32 \mathrm{~mm}$.; thickness, $0.12 \mathrm{~mm}$. Holotype.-Cat. No. 371021, U.S.N.M.

It differs from any other known Sigmomorphina in its strongly inflated longitudinal ridge developed in the portion corresponding to the line of the apertures of each of the sigmoid series of chambers.

Distribution.-Eocene, $17 \frac{1}{2}$ miles south of Palestine Road on Grapeland Road, first creek crossed by fording north of Grapeland, Houston County, Tex. It occurs in the Mount Selman and Cooks Mountain greensands of the Eocene of Texas.

SIGMOMORPHINA REGULARIS (v. Münster)

Plate 33, figures $1 a, b$

Polymorphina regularis v. Münster, in Roemer, Neues Jahrb. für Min., ete., 1838, p. 385, pl. 3, fig. 21.-Reuss, Sitz. Akad. Wiss. Wien, vol. 18, 1855 (1856), p. 247, pl. 7, figs. 70-73.-H. B. Brady, PArker, and Jones, Trans. Linn. Soc., vol. 27, 1869, p. 229, pl. 40, figs. $13 a-c$.-Weller, Geol. Surv.New Jersey, Paleontology, vol. 4, 1907, p. 253, pl. 3, figs. $29-31$.

Polymorphina anceps Philippi, Beitr. Kennt. Tert. nordwest. Deutschlands, 1843, p. 41, pl. 1, fig. 34.-Reuss, Sitz. Akad. Wiss. Wien, vol. 18, 1855 (1856), p. 246 , pl. 6 , fig. 68 ; pl. 7 , fig. 69 ; vol. 50, abt. 1,1864 , p. 472 , pl. 3 , figs. 11,12 ; pl. 4, figs. 1-3; Denkschr. k. Akad. Wiss. Wien, vol. 25, 1865, p. 155, pl. 4, figs. 9-11.-H. B. Brady, Parker, and Jones, Trans. Linn. Soc., vol. 27, 1870, p. 223, pl. 39, fig. $8 a-c$.

Polymorphina compressa Philippi, Beitr. Kennt. Tert. nordwest. Deutschlands, 1843 , p. 69 , pl. 1, fig. 35 .

Polymorphina humboldti Bornemann, Zeitschr. deutsch. geol. Gesell., vol. 7, 1855, p. 347, pl. 18, figs. 7, 8.-H. B. Brady, Parker, and Jones, Trans. Linn. Soc., vol. 27, 1870, p. 236, pl. 40, figs. $21 a$, b.-Reuss, Sitz. Akad. Wiss. Wien, vol. 62, pt. 1, 1870, p. 488.- v. Sснцicht, Foram. Septar. Pietzpuhl, 1870, pl. 32, figs. 23-26, 29-32, 35-38.

Test oval (young) to oblong (adult), compressed, broadest in the upper half, margin angular; chambers compressed, long, arranged in a clockwise, sigmoid series, each succeeding chamber removed much farther from the base; sutures not depressed, limbate; wall smooth, translucent; aperture radiate.

Maximum length of our specimens, $2.70 \mathrm{~mm}$.; breadth, $1.20 \mathrm{~mm}$.; thickness, $0.65 \mathrm{~mm}$.

This species has been described by German authors under different names as the above synonymy shows. This is not surprising; 
and if we compare only the figures, we are easily led to separate them into many species.

Roemer's figures of Polymorphina regularis are fairly well drawn and show the characteristics of the species-a clockwise sigmoid arrangement of chambers, each succeeding chamber removed farther from the base. Accordingly, the side view shows that on the right side more than two-thirds of the surface is occupied by a series of regularly arranged, not much embracing, elongate chambers, while on the left is a series of a lesser number of much embracing, wide, and short chambers.

Bornemann's figures of Polymorphina humbolditi appear to be more inflated than Polymorphina regularis, but all of Bornemann's specimens are few chambered and undoubtedly represent young stages of the present species as his measurements show. Bornemann's specimens measure from $0.6 \mathrm{~mm}$. to $1.5 \mathrm{~mm}$. in length while Roemer's specimen having numerous chambers is much larger, attaining almost $3 \mathrm{~mm}$. in length. We have a good series of the species from young to adult obtained from Cassel, Germany.

Strictly speaking, it is not certain whether or not Reuss's Polymorphina regularis is the same as that figured by Roemer, because, when he described Polymorphina anceps Philippi in $1855^{10}$ he placed under its synonymy the Polymorphina regularis described by him in 1851 and Polymorphina compressa Philippi not Polymorphina regularis v. Münster in Roemer. Moreover, he gave the precedence to Polymorphina anceps described later than Polymorphina regularis. However, his figures of Polymorphina anceps in the same paper are all given the name of Polymorphina regularis. Reuss's figures show that his Polymorphina anceps or regularis has the chambers regularly alternating in a biserial series as in Polymorphina compressa and $P$. anceps reported by Philippi, and as far as his figures are concerned his species as well as Philippi's Polymorphina anceps differs from either Polymorphina regularis v. Münster or Polymorphina humboldti Bornemann.

We have examined a large number of specimens obtained from the Oligocene deposits of various localities in Germany, but could not find any specimen like Philippi's Polymorphina anceps which, according to Reuss, is not rare. Therefore it may be supposed that Polymorphina anceps is the same as Polymorphina regularis, and the figures of the species given by Philippi and Reuss are much conventionalized according to their conception of the Polymorphinidae. Specimens having a sigmoid arrangement of chambers are very often mistaken by various authors and not well drawn. 
Distribution.-Sigmomorphina regularis is one of the specialized species and appears to be limited to the German Oligocene and possibly the Cooper marl of the United States. We have specimens from the following localities:

Oligocene.-Germany, Ahnatal, near Cassel (abundant); Hermsdorf, near Berlin; Doberg, near Bünde; Escherhausen; Düsseldorf; Dickholzen, Hildesheimeswald.

Upper Eocene.-Cooper marl, United States, Cooper River, S. C.; pit on United States Highway No. 17 about 1 mile south of Moncks Corner, Berkeley County, S. C.

\section{SIGMOMORPHINA FRONDICULARIFORMIS (Galloway and Wissler)}

Plate 33, figures $2 a, b$

Polymorphina frondiculariformis Galloway and Wissler, Journ. Pal., vol. 1, 1927, p. 55, pl. 9, fig. 6 .

Sigmomorpha (Sigmomorphina) frondiculariformis Cushman and Ozawa, Contr. Cushman Lab. Foram. Res., vol. 4, 1928, pl. 2, fig. 12.-Cushman, Special Publ. No. 1, Cushman Lab. Foram. Res., 1928, pl. 27, fig. 12.-Cushman and Ozawa, Jap. Journ. Geol. Geogr., vol. 6, 1929, p. 81 , pl. 17, fig. 23 .

Frondicularia inaequalis BAGG (not Costa), Bull. 513, U. S. Geol. Survey, 1912, p. 60 , pl. 18, figs. $1,2$.

Test elongate, lanceolate, compressed, the initial end with a prominent spine; chambers elongated, compressed, arranged in a contraclockwise sigmoid series, each succeeding chamber only slightly removed from the base; sutures slightly depressed, distinct; wall smooth; aperture produced, radiate.

Maximum length $2 \mathrm{~mm}$; breadth $0.70 \mathrm{~mm}$.; thickness $0.20 \mathrm{~mm}$.

The present species is one of the well defined species of the genus. Its elongated chambers arranged in an open sigmoid series and its strong initial spine are the characteristics of the species by which it is easily distinguished from others of the genus.

Distribution.-This species is only known from the later Tertiary in California and Recent off the coast. It is common in the upper Pliocene of Timms point, San Pedro, Calif., and rare in the Pleistocene of Lomita quarry, Palos Verdes Hills. We also have the species from off La Jolla, Calif.

\section{SIGMOMORPHINA TORTA (Galloway and Wissler)}

\section{Plate 33, figure 3}

Polymorphina torta Galloway and Wissler, Journ. Pal., vol. 1, 1927, p. 55 , pl. 9 , fig. 5 .

Sigmomorphina torta Cushman and Ozawa, Jap. Journ. Geol. Geogr., vol. 6, 1929 , p. 81.

Test elongate, elliptical, acuminate toward the base, compressed and twisted, the initial end with a blunt spine; chambers elongate, 
slightly twisted, not much embracing, arranged in a contraclockwise sigmoid series, each succeeding chamber removed farther from the base; sutures but little depressed, distinct; wall smooth; aperture produced, radiate.

Maximum length $1.50 \mathrm{~mm}$; breadth $0.35 \mathrm{~mm}$.

Sigmomorphina torta is evidently related to Sigmomorphina frondiculariformis from which it is derived by having the chambers shortened and more or less curved and accordingly the test is twisted. It is one of the most specialized species of the genus.

Distribution.-Galloway and Wissler described the species from the Pleistocene D. M. S. and B. quarry, Lomita, Palos Verdes Hills, and from the Pliocene of Timms Point, Calif. We have specimens from both localities, and also Recent specimens from off the southern California coast.

\section{SIGMOMORPHINA SEMITECTA (Reuss)}

Plate 33 , figures 6,7

Polymorphina semitecta Reuss, Sitz. Akad. Wiss. Wien, vol. 55, pt. 1, 1867, p. 91, pl. 3, fig. 10 .

Polymorphina lucida D'Orbigny, Ann. Sci. Nat., vol. 7, 1826, p. 266, No. 18.-Fornasini, Mem. Accad. Sci. Istit. Bologna, ser. 5, vol. 10, 1902, p. 51 , fig. 50 (in text).

Test compressed, oval to ovate, broadly rounded at the base, tapering toward the aperture; chambers elongate, arranged in a clockwise sigmoid series, all extending down to the base, but not involute; sutures scarcely depressed, distinct; wall smooth, the apertural end often with fistulose tubes; aperture radiate.

Length $0.55 \mathrm{~mm}$.; breadth $0.37 \mathrm{~mm}$.; thickness $0.12 \mathrm{~mm}$.

The nearest ally of the present species is Sigmomorphina undulosa, which has elongated chambers arranged in a sigmoid series, but each succeeding chamber is much farther removed from the base and not extending down to the base, as in the present species.

Guttulina lucida d'Orbigny, figured by Fornasini, is undoubtedly a young specimen of the present species.

Distribution.-We have specimens referable to the present species from the following localities:

Miocene.-France, Aquitanien superieur, La Brede, Larriey. Hungary, Tortonian shell sand, Varpolata.

Eocene.-France, Lutetien, Parnes (Les Bôves).

SIGMOMORPHINA SEMITECTA (Reuss) var. TERQUEMIANA (Fornasini)

Plate 33, figures 4, 5; Plate 34, figures 2, 3; Plate 35, figure 1.

Polymorphina amygdaloides Reuss var. terquemiana Fonnasini, Mem. Accad.

Istit. Sci. Bologna, ser. 5, vol. 9, 1900-1902 (1902), p. 72, fig. 25 (in text).

Polymorphina amygdaloides Terquem, Mém. Soc. Géol. France, sér. 3, vol.

2, 1882, p. 141, pl. 14 (22), figs. $30,31$.

$92709-30-9$ 
Polymorphina pauperata Terquem, Mém. Soc. Géol. France, sér. 3, vol. 1, 1878 , p. 38 , pl. 3 (8), figs. 11 a to 19.

Globulina varians Terquem, Mém. Soc. Géol. France, sér. 3, vol. 2, 1882, p. 128, pl. 13 (21), figs, 9-16.

Variety differing from the typical in its more elongate lanceolate test consisting of elongated chambers and more acute initial end.

Polymorphina pauperata Terquem, described from the Pliocene of the Isle of Rhodes, is a compressed lanceolate form having an acute initial end. It is a few-chambered specimen and resembles a compressed Globulina. We have several such specimens which are invariably small, and they appear to us to represent a young stage of the present variety. Globulina varians Terquem from the Eocene of Vaudancourt may be also placed under the present species, as far as his first and second figures are concerned.

Distribution.-We have specimens more or less typical from the following localities:

Recent.-Mediterranean, 10-14 fathoms, off the island of Delos.

Pliocene.-Italy, Castel Arquato.

Miocene.-France, Burdigalien inferieur, Le Coquillat, Leognan; Moulin de l'Eglise, Saucats.

- Eocene.-France, Lutetien, Chaussy; Grignon. United States, Jackson, east bank of Sepulga River, about 4 miles northeast of Brooklyn, Conecuh County, Ala.; Rich Hill, Crawford County, Ga.

\section{SIGMOMORPHINA SCHWAGERI (Karrer)}

Plate 34, figures $1 a-c$

Polymorphina schwageri KarRer, Abhandl. k. k. geol. Reichs., vol. 9, 1877, p. 384 , pl. 16 b, fig. 43 .

Polymorphina (Guttulina) megapolitana Clodius, Archiv. Ver. Fremde Nat. Mecklenburg, 75 Jahr., 1922, p. 126, pl. 1, fig. 9 a-c.

Polymorphina regularis Hosıus, Ver. Nat. Hist. Vereins Pr. Rheinlande, vol. 50,1893 , p. 107 , pl. 2 , fig. 8 .

Test elongate, equilateral, equally compressed on either side, margin rounded; chambers slightly inflated, not much overlapping, arranged in a clockwise sigmoid series, each succeeding chamber removed farther from the base; sutures but little depressed, distinct; wall thick, smooth; aperture radiate.

Length of figured specimen $1.80 \mathrm{~mm}$.; breadth $0.95 \mathrm{~mm}$.; thickness $0.30 \mathrm{~mm}$.

Karrer's Polymorphina schwageri is fairly well drawn in its sigmoid arrangement of chambers, although he did not describe it correctly. It is a well-defined species, and there is no other to be confused with it. Sigmomorphina regularis has the same arrangement of chambers, but it is more compressed, especially on the margin. 
Polymorphina megapolitana, described by Clodius from the Miocene of Mecklenburg, is placed under the present species although it has a spine at the initial end.

Distribution.-The present species seems to be limited to the later Tertiary in Europe. Karrer described it from Lapugy in Siebenburgen. Clodius's specimens are also from the Miocene. We have it from the Crag of Sutton, England, and from the Miocene, Burdigalien inferieur, Le Coquillat, Leognan, France. A form very similar to this occurs in the upper Pliocene, Natsukawa limestone, Natsukawa, Province of Echigo, Japan.

\section{SIGMOMORPHINA UNDULOSA (Terquem)}

Plate 34 , figures 4,5

Polymorphina amygdaloides Terquem (not Reuss), Mém. Soc. Géol. France, sér. 3 , vol. 1, 1878, p. 39, pl. 3 (8), figs. 22,25 (not 23, 24, 26-30).

Polymorphina undulosa Terouem, Mém. Soc. Géol. France, sér. 3, vol. 1, 1878 , p. 41 , pl. 3 (8), figs. $35 a, b$, (not 36 ).

Test oval to ovate, compressed; chambers elongated, embracing, arranged in a contraclockwise sigmoid series, each succeeding chamber not much removed from the base; sutures depressed, distinct; wall smooth, rather thin, often covered with fistulose tubes; aperture radiate.

Maximum length $0.60 \mathrm{~mm}$; ; breadth $0.30 \mathrm{~mm}$.; thickness $0.15 \mathrm{~mm}$.

This species is undoubtedly related to Guttulina lactea, from which it is derived by losing the quinqueloculine arrangement of chambers and becoming sigmoidal. The direction of the sigmoid arrangement of chambers appears not to be definitely fixed, and rarely there are some specimens showing a clockwise sigmoid arrangement of chambers.

Some figures of Polymorphina amygdaloides Terquem (the first figure of the species, 22 , and fig. $25, ? 26$ ), described in 1878, coincide with the present species, but the specific name amygdaloides is preoccupied by Reuss in 1856 (Globulina amygdaloides Reuss in 1851); therefore undulosa is chosen for the present species.

Distribution.-S. undulosa occurs in European late Tertiary deposits as well as in the Recent state. We have specimens of the species from the localities listed below:

Recent.-Atlantic, Lord Bandon, dredgings southwest of Ireland; coast of Iceland; coast of Brazil; Dry Tortugas, Fla., 18 fathoms.

Pliocene.-England, Crag of Sutton.

SIGMOMORPHINA LAMARCKI Cushman and Ozawa, new species

Plate 34, figures $6 a-c$

Test oval, rounded at the base, obtuse at the apertural end, compressed, periphery rounded; chambers much longer than wide, 
slightly compressed, slightly embracing, arranged in a clockwise sigmoid series, each succeeding chamber farther removed from the base; sutures somewhat depressed, distinct; wall entirely ornamented by numerous fine costae, rather thick; aperture radiate.

Length of holotype $0.62 \mathrm{~mm}$.; breadth $0.32 \mathrm{~mm}$.; thickness $0.15 \mathrm{~mm}$. Holotype-(Cushman Coll. No. 11840.) From the Eocene (Lutetien), Campbon, France.

The general outline is very similar to Sigmomorphina semitecta, but it is ornamented and the test has a tendency to elongate. The specific name is given for Lamarck.

SIGMOMORPHINA PEARCEYI Cushman and Ozawa, new species

Plate 35 , figures 2,3

Polymorphina inflata Pearcey, Trans. Roy. Soc. Edinburg, vol. 49, 1914, p. 1,023 , pl. 2 , figs. $14-16$.

Test elongate, clavate, the greatest breadth in the upper half, tapering toward the base, apertural end rounded; chambers more or less compressed, early ones elongated, later becoming rounded, generally the last one much inflated and large, arranged in a contraclockwise sigmoid series, each succeeding chamber, especially the last one or two, removed farther from the base; sutures depressed, distinct; wall smooth, thin, translucent; aperture near the center of the last chamber, with short entosolenian tube.

Length of largest specimen $0.80 \mathrm{~mm}$.; breadth $0.50 \mathrm{~mm}$.; thickness $0.45 \mathrm{~mm}$.

Holotype-(Cushman Coll. No. 11841.) From off Dry Tortugas, Fla., 18 fathoms.

The later chambers of the present species tend to become more circular and are removed farther from the base, yet they are arranged in a sigmoid series. This species is well characterized and for the first time described by Pearcey under the name "Polymorphina inflata," but the name is preoccupied first by Zittel in 1876, and secondly by Terquem in 1886. Zittel's Polymorphina inflata is apparently a mistake for P. lactea Williamson, as explained by Sherborn. Globulina inflata Reuss is different from either Zittel's or Terquem's $P$. inflata.

We can not use the specific name "inflata" for the present species; therefore "pearceyi" is proposed for Pearcey, the first recorder of the species.

Distribution.-It is a very rare species. Pearcey recorded it from the Scottish Antarctic Expedition collections. We have one specimen from the Eocene of Val di Lonte, Italy, and two specimens from the Atlantic, off Gaspé, between Ship Head and Cape Bonne Ami, 30 fathoms, and off the Tortugas, Fla., 18 fathoms. The range of these three specimens seems to show that even though they seem very much alike, more material may show that these are not all the same. 


\section{SIGMOMORPHINA CRASSA (Roemer)}

Plate 35 , figures 4,5

Polymorphina crassa Roemer, Neues Jahrb. f. Min. etc., 1838, p. 385, pl. 3, fig. 27.-Reuss, Sitz. Akad. Wiss. Wíen, vol. 18, 1855 (1856), p. 250, pl. 8 , fig. 82 .

Polymorphina crassatina v. MüNster, Neues Jahrb. f. Min., etc., 1838, p. 385 , pl. 3 , fig. 30 .

Guttulina robusta Reuss, Sitz. Akad. Wiss. Wien, vol. 18, 1855 (1856), p. 246, pl. 6, fig. 65 .

Polymorphina problema D'ORBIGny var. deltoidea Reuss, Denkschr. k. Akad. Wiss. Wien, vol. 25,1865 , p. 154 , pl. 4 , fig. 8 .

Polymorphina insignis Reuss, Sitz. Akad. Wiss. Wien, vol. 18, 1855 (1856), p. 248, pl. 7 , figs. 74,75 .

Test broadly oval to oblong, greatest width above the middle; chambers inflated, arranged at first in a quinqueloculine series, becoming biserial later, each succeeding chamber removed much farther from the base; sutures depressed, distinct; wall thick, smooth; aperture radiate.

Maximum length $2.25 \mathrm{~mm}$; ; breadth $1.60 \mathrm{~mm}$.; thickness $0.45 \mathrm{~mm}$.

Sigmomorphina crassa is fairly large, and even a young specimen, which may closely resemble Guttulina problema in general features, is much larger than an adult of that species. This circumstance has led Reuss to give the present species several specific names in different stages of growth. Our study of a large number of specimens obtained from the German Oligocene, showed that Reuss's Polymorphina problema var. deltoidea is a young phase of $P$. crassa. His Guttulina robusta, together with Polymorphina (Guttulina) crassatina Münster, has one more chamber added. Polymorphina insignis, a very large specimen attaining to $2.6 \mathrm{~mm}$. in length, is the adult and has the later chambers arranged in a sigmoid series as in Sigmomorphina crassa (Roemer).

Distribution.-The present species seems to be restricted to the German Oligocene where specimens are fairly common. We have abundant specimens from the upper Oligocene of Ahnatal, near Cassel, Germany.

\section{SIGMOMORPHINA SCHENCKI Cushman and Ozawa, new species}

Plate 35 , figures $6 a, b$

Test compressed, broadly ovate, greatest breadth near the base; chambers elongated, embracing, arranged in a clockwise sigmoid series, each succeeding chamber slightly removed from the base; sutures not depressed, distinct; wall rather thick, smooth; aperture radiate.

Length of holotype $1.20 \mathrm{~mm}$.; breadth $0.90 \mathrm{~mm}$.; thickness $0.40 \mathrm{~mm}$. Holotype-(Cushman Coll. No. 10147.) From the Oligocene (Keasey shale), Oregon. 
In the general outline, it resembles Japanese Pliocene Sigmomorphina kotoi, but it is much larger and the chambers broader compared with the length. It more or less resembles Sigmomorphina crassa from the German Oligocene, but it has an advanced sigmoid arrangement of chambers, and the chambers are much elongated.

The species is named for Dr. H. G. Schenck of the Geological Department of Stanford University.

SIGMOMORPHINA KOTOI Cushman and Ozawa, new species

Plate 35, figures $7 a, b$

Test compressed, ovate, broadly rounded at the base, tapering toward the aperture, periphery somewhat angulate; chambers more or less compressed, elongated, arranged in a clockwise sigmoid series, each succeeding chamber slightly removed from the base; sutures not depressed, distinct; wall smooth, translucent; aperture radiate.

Length of holotype $0.65 \mathrm{~mm}$.; breadth $0.40 \mathrm{~mm}$.; thickness $0.17 \mathrm{~mm}$. Holotype.-(Cushman Coll. No. 11848.) From the upper Pliocene, Natsukawa, in Province of Echigo, Japan.

The characteristic feature of the present species is its ovate test composed of elongated chambers which extend down to the base. The species is named for Emeritus Prof. B. Koto, Imperial University of Tokyo, Japan.

Distribution.-Known only from the upper Pliocene of Japan.

\section{SIGMOMORPHINA TRINITATENSIS Cushman and Ozawa, new species}

Plate 36, figures 1,2

Test elongated, greatest breadth near the base, broadly rounded at the base, uniformly tapering toward the acute apertural end; chambers elongated, more or less cylindrical, embracing, arranged in a clockwise sigmoid series; sutures not depressed, distinct; wall rather thick, smooth; aperture radiate.

Length of holotype $1.45 \mathrm{~mm}$.; breadth $0.90 \mathrm{~mm}$.; thickness $0.55 \mathrm{~mm}$.

Holotype.-(Cushman Coll. No. 11849.) From the Eocene, Hermitage quarry, Dumfries Road, Trinidad, British West Indies.

The elongated test, somewhat like an isosceles triangle in its side view, is very characteristic of the species.

Distribution.-In addition to the Trinidad specimens, we have a very similar specimen from the Eocene of Vincentown, N. J.

\section{SIGMOMORPHINA BORNEMANNI Cushman and Ozawa, new species}

Plate 36 , figures $3 a, b$

Polymorphina dilatata Reuss, Zeitschr. deutsch. geol. Ges., vol. 3, 1851, p. 83 , pl. 6 , fig. 49 .

Test compressed, equilaterally triangular with rounded peripheries and angles, initial end slightly produced, margin thin and rather 
acute; chambers compressed, elongate, arranged in a clockwise sigmoid series, each succeeding chamber not much removed from the base; sutures not depressed but distinct; wall smooth, thick; aperture radiate.

Length of figured specimen $0.90 \mathrm{~mm}$; breadth $0.75 \mathrm{~mm}$; thickness $0.40 \mathrm{~mm}$.

Holotype.-(Cushman Coll. No. 11851.) From middle Oligocene, Hermsdorf, near Berlin, Germany.

Sigmomorphina bornemanni bears a close relationship to $S$. regularis and might be taken as a young stage of the latter, and naturally Reuss himself placed it under Polymorphina anceps ( $=S$. regularis). If however, we compare the species with a young specimen of Sigmomorphina regularis, for example, such specimens as figured by Bornemann under the name of $P$. humboldti, it is not difficult to separate them. In Sigmomorphina bornemanni each succeeding chamber is added laterally and all chambers extend down almost to the base, while in S. regularis, even in its young stage, each succeeding chamber is removed from the base so that the test is much elongated. Sigmomorphina bornemanni might be considered to represent the microspheric form of $S$. regularis, but we have no evidence to assume it.

Polymorphina dilatata is preoccupied by d'Orbigny, therefore a new specific name bornemanni is given for Bornemann. It must be noticed here that Guttulina dilatata Reuss described from the Vienna Tertiary is different from the present species, although some authors have considered them the same.

Distribution.-Reuss described the present species from the Oligocene of Hermsdorf near Berlin where it occurs rarely. We have specimens from the original locality as well as from the Oligocene of Düsseldorf, and Ahnatal, near Cassel.

\section{SIGMOMORPHINA GALLOWAYI Cushman and Ozawa, new species}

Plate 36 , figures $4 a, b$

Test compressed, more or less twisted, oval in side view, caudate at the initjal end; chambers elongated, slightly compressed, arranged in a contraclockwise sigmoid series, each succeeding chamber not much removed from the base; sutures but little depressed, distinct; wall smooth, rather thin, transparent; aperture radiate.

Length of holotype $0.90 \mathrm{~mm}$.; breadth $0.55 \mathrm{~mm}$.; thickness $0.22 \mathrm{~mm}$. Holotype.-(Cushman Coll. No. 11855.) From Albatross D4807, coast of Japan.

The twisted, compressed, oval test is characteristic of the species. Its nearest ally is Sigmomorphina aliceae, which is more elongated, and the chambers shorter and broader. This species is named for Dr. J. J. Galloway, of Columbia University.

Distribution.-Known only from off the coast of Japan. 
Plate 36, figures $5 a-c$

Polymorphina trilocularis BAGG, U. S. Geol. Survey Bull. 513, 1912, p. 75, pl. 20, figs. 15-18.

Sigmomorpha trilocularis Cushman and Ozawa, Jap. Journ. Geol. Geogr., vol. 6,1928 , p. 74 , pl. 16, fig. 5 .

Test small, ovate, more or less rounded at the base, rather acute toward the apertural end; chambers much elongated and slender, roundly triangular in cross section, slightly embracing, arranged in a contraclockwise sigmoid series, each succeeding chamber removed from the base; sutures depressed, distinct; wall smooth, thin; aperture radiate.

Maximum length $0.90 \mathrm{~mm}$; breadth $0.35 \mathrm{~mm}$.; thickness $0.20 \mathrm{~mm}$.

Its elongated, slender chambers arranged in a more or less sigmoid series are the characteristics of the species. Its sigmoid arrangement of chambers is somewhat variable, and often it is closed, showing more or less a quinqueloculine series.

Distribution.-Only known in the North Pacific region as a late Tertiary fossil and as a Recent species. We have the species from the following localities:

Recent.-Off coast of southern California.

Pliocene.-Timms Point, San Pedro, Calif. Upper Pliocene, Natsukawa, Province of Echigo, Japan.

SIGMOMORPHINA YOKOYAMAI Cushman and Ozawa

Plate 36, figures $6 a, b$

Sigmomorpha (Sigmomorphina) yokoyamai Cushman and Ozawa, Contr. Cushman Lab. Foram. Res., vol. 4, 1928, p. 18, pl. 1, fig. 16; Jap. Journ. Geol. Geogr., vol. 6, 1929, p. 75, pl. 13, figs. 12-14; pl. 16, figs. 7, 8.

Test ovate, greatest breadth toward the base, tapering toward the apertural end, periphery sharply angled and carinate in the adult; chambers comparatively few in the megalospheric form, more numerous in the microspheric; chambers elongated and very narrow, arranged in an open sigmoid series and added so that the axis of each chamber is somewhat oblique giving a peculiar twisted appearance to the test; sutures distinct, very slightly depressed; wall thin, transparent, with longitudinal costae which are continuations from the ridges of the radiate apertures of each chamber, in some specimens with additional costae covering the entire surface; aperture radiate, terminal, somewhat produced into a cylindrical neck.

Length of holotype $0.93 \mathrm{~mm}$; ; breadth $0.50 \mathrm{~mm}$.

This species is common and shows some variations in the surface ornamentation, some of the specimens being smooth except for the costae of the central portion, others being costate throughout. This is one of the most striking species of the Japanese collection and is 
named for Dr. M. Yokoyama, who described the fossil mollusks from the same locality.

Distribution.-Our specimens are from the upper Pliocene of Sawane, island of Sado, and from Natsukawa, Province of Echigo, Japan.

\section{SIGMOMORPHINA SAWANENSIS (Cushman and Ozawa)}

Plate 38, figures $1 a, b$

Sigmomorpha sawanensis Cushman and Ozawa, Jap. Journ. Geol. Geogr., vol. 6,1929 , p. 74 , pl. 16 , fig. 6 .

Test ovate, greatest breadth just above the base, tapering toward the apertural end; chambers numerous, elongate, about five times as long as broad in the adult, each chamber reaching nearly to the base, arranged in a contraclockwise sigmoid series; sutures distinct, slightly depressed; wall of medium thickness, smooth, translucent; aperture radiate.

Measurement of the holotype specimen: Length $0.76 \mathrm{~mm}$; breadth $0.33 \mathrm{~mm}$.; thickness $0.25 \mathrm{~mm}$.

This has a very much more elongate form than Sigmomorphina sadoensis and is more involute than that species, the chambers being very much longer and inclosing the earlier ones. It differs from the European Sigmomorphina semitecta in its more broadly rounded base.

Distribution.-The type specimens are from the upper Pliocene of Sawane, island of Sado, Japan. We have additional specimens from the upper Pliocene of Natsukawa, Province of Echigo, Japan.

SIGMOMORPHINA VAUGHANI Cushman and Ozawa, new species

Plate 38 , figures $2 a-c$

Test almost rhombic with three rounded angles and acute apertural angle, compressed, and more or less twisted, margin of the lower half, wavy; chambers compressed, elongated, arranged in a clockwise sigmoid series, each succeeding chamber farther removed from the base; sutures slightly depressed, distinct; wall smooth; aperture radiate.

Length of holotype $0.80 \mathrm{~mm}$; breadth $0.62 \mathrm{~mm}$.; thickness 0.30 $\mathrm{mm}$.

Holotype-(Cat. No. 371262, U.S.N.M.) From the Eocene (Cooper marl) at Ingleside marl pit, Charleston, S. C. (U. S. Geol. Survey 6319).

It differs from Sigmomorphina bornemanni from the German Oligocene in its twisted test, wavy margins and more or less depressed sutures. This species is named for Dr. T. Wayland Vaughan of the Scripps Institution of Oceanography.

Distribution.-Upper Eocene, United States, Cooper marl. In addition to the type locality this species also occurs in the Cooper 
marl of Cooper River, S. C. and in a pit on the United States Highway No. 17, about 1 mile south of Monck's Corner, Berkeley County, S. C.

\section{SIGMOMORPHINA WILLIAMSONI (Terquem)}

Plate 38 , figures 3,4

Polymorphina williamsoni Terquem, Mém. Soc. Géol. France, sér. 3, vol. 1,1878, p. 37.

Polymorphina lactea WALker and JACoB var. oblonga Williamson, Recent Foram. Great Britain, 1858, p. 71, pl. 6, figs. 149, 149a.-Millett, Journ. Roy. Micr. Soc., 1903, p. 262, pl. 5, fig. 5.-СhapMan, Journ. Linn. Soc. Zool., vol. 30, 1910, p. 413, pl. 55, fig. 12.-Cushman; Bull. 104, U. S. Nat. Mus., pt. 4, 1923, p. 147 , pl. 40 , figs. $7,8$.

Polymorphina compressa Egger, Abhandl. kön. bay. Akad. Wiss., München, Cl. II, vol. 18 , 1893, p. 309, pl. 9, figs. 11-13.

Polymorphina formosa Egger, Abhandl. kön. bay. Akad. Wiss., München, Cl. II, vol. 18,1893 , p. 440 , pl. 9, figs. 17-19.

Polymorphina mucronata Terquem (not Terquem, 1878), Essai Class. Anim. Dunkerque, 1881, p. 130, pl. 17, fig. 3.

Polymorphina oblonga, H. B. Brady, Parker, and Jones, Trans. Linn. Soc., vol. 27, 1870, p. 222, pl. 39, figs. $7 a, b$. -Terquem, Essai Class. Anim. Dunkerque, 1875, p. 37, pl. 5, fig. 11.-Heron-Allen and Earland, Proc. Roy. Irish Acad., vol. 31, pt. 64, 1913, p. 100, pl. 8, fig. 17.

Dimorphina millettii Sideвоттом, Journ. Roy. Micr. Soc., 1918, p. 145, pl. 5, figs. 15, 16.

Test ovate to oblong, compressed, of nearly equal thickness, sides nearly parallel, rounded at both ends; chambers elongated, embracing, arranged in a contraclockwise, sigmoid series, each succeeding chamber extending down to the base; sutures scarcely depressed, but distinct; wall smooth, thin, nearly transparent; aperture long, radiate, furnished with an entosolenian tube.

Maximum length $0.92 \mathrm{~mm}$.; breadth $0.42 \mathrm{~mm}$.; thickness $0.20 \mathrm{~mm}$.

Sigmomorphina williamsoni is a well-marked species and is first recorded by Williamson from Southport, England, under the name "Polymorphina lactea var. oblonga." Brady, Parker, and Jones used the varietal name as the specific name, but much later Terquem changed the name "oblonga" to "williamsoni," as oblonga is preoccupied by d'Orbigny.

Polymorphina formosa Egger and P. mucronata Terquem, characterized by an oblong test with almost parallel peripheries, resemble the present species and can be included in it, although $P$. mucronata has a spine at the initial end.

Polymorphina compressa Egger (not Philippi, not d'Orbigny) is rather shorter than the typical specimen, but is to be placed in the synonymy of the present species.

Often the present species apparently shows an alternating chamber on one side on account of an incomplete overlapping of chambers, but the real arrangement of the chambers is always sigmoidal. 
Dimorphina millettii, described by Sidebottom from off the east coast of Australia, 465 fathoms, having an elongated quadrangular test with a sigmoid arrangement of the chambers, is very similar to S. williamsoni. The difference is only an extra chamber which is added on the top of the main test. Such specimens, having a round extra chamber, are often found in shallow water off England and Belgium.

Distribution.-S. williamsoni appears to be rather common in the shallow water off England and Belgium, from where we have numerous specimens. Some forms very similar to the present species are reported from off east Australia. We also have a few fossil specimens which are something like the present species, but not enough material to be positive of the identification.

\section{SIGMOMORPHINA CONCAVA (Williamson)}

Plate 38 , figures 5-7

Polymorphina lactea WALKER and JACOB var. concava Williamson, Recent Foram. Great Britain, 1858, p. 72, pl. 6, figs. 151, 152.

Excepting the last attached part, the test is oval and much compressed; chambers elongate, much embracing unequally on either side, each succeeding chamber extending down to the base, attached part (or chamber ?) generally highly convex, leaving a large space between the test and the foreign object, but without visible aperture; sutures not depressed, distinct; wall smooth, rather thin and almost transparent; aperture radiate.

Williamson was the first who noticed an unmistakably parasitic species of the Polymorphinidae which he named Polymorphina concava. We have several attached specimens, some of which are the same as that figured by Williamson. The present species is undoubtedly a specialized one among the Polymorphinidae. No other species having a test resembling that of Sigmomorphina concava is known, therefore Williamson's species is taken as a valid one.

Distribution.-Sigmomorphina concava seems to be extremely rare. Williamson gives Brixham, England, as the locality whence his specimens were obtained. We have specimens from off the Belgian coast, from the Mediterranean, and off the island of Delos, 10-14 fathoms. We have also a specimen here figured from the Pliocene of 'Monte Mario, near Rome.

SIGMOMORPHINA ALICEAE Cushman and Ozawa, new species

Plate 38, figures $8 a, b$

Test oblong, compressed, twisted nearly $180^{\circ}$, greatest width in upper half, tapering toward the initial end; chambers elongated, especially the early ones, later ones becoming broader, compressed, not much embracing, arranged in a contraclockwise sigmoid series, 
each succeeding chamber farther removed from the base; sutures but little depressed, distinct; wall of medium thickness, smooth; aperture radiate.

Maximum length $1.55 \mathrm{~mm}$.; breadth $0.80 \mathrm{~mm}$.; thickness $0.35 \mathrm{~mm}$.

Holotype.-(Cat. No. 20856, U.S.N.M.) From Albatross D4805, off Japan.

Sigmomorphina aliceae is twisted, as is S. torta, from which it is quite distinct in its flat later chambers. In general appearance, it resembles Sigmomorphina pearceyi, but the latter has inflated chambers, and the test is not twisted as much as in the present species. The specific name is given for Alice E. Cushman, who took much care in preparing our manuscript and in checking our proofs.

Distribution.-Known only from off the coast of Japan.

Genus SIGMOIDELLA Cushman and Ozawa, 1928

Sig MOIDELla ELEGanTiSsima (Parker and Jones)

Plate 39, figure $1 a-c$

Polymorphina elegantissima PARKer and Jones, Phil. Trans., vol. 155, 1865, Table X, p. 438.-H. B. Brady, Parker, and Jones, Trans. Linn. Soc., vol. 27, 1870, p. 231, pl. 40, figs. $15 b, c$ (not $a$ ).-H. B. Brady, Rep. Voy. Challenger, Zoology, vol. 9, 1884, p. 566, pl. 72, fig. 13 (not figs. 12, 14, 15).-Flint, U. S. Nat. Mus. Rept., 1897, p. 319, pl. 67, fig. 4.-BAGG, Maryland Geol. Surv. (Eocene), 1901, p. 247, pl. 63, fig. 11; (Miocene), 1904, p. 476, pl. 133, fig. 3.-Cushman, Bull. 71, U. S. Nat. Mus., pt. 3, 1913, p. 90, pl. 38, fig. 1; U. S. Nat. Mus., Bull. 100, vol. 4, 1921, p. 267, pl. 54, figs. 1, 2.-Nuttall, Quart. Journ. Geol. Soc., vol. 84, 1928, p. 93, pl. 6, fig. 10.

Sigmoidella elegantissima Cushman and Ozawa, Jap. Journ. Geol. \& Geogr., vol. 6,1929 , p. 76 , pl. 16 , figs. $10,11$.

Test compressed, almost circular excepting the slightly acute, apertural end, margins angular; chambers elongate, overlapping, arranged in a clockwise sigmoid series, each succeeding chamber becoming much larger and embracing those previously formed, but in old age specimens, the last one or two chambers not extending down to the base; sutures not depressed, but generally distinct; wall smooth; aperture radiate.

Maximum length $2 \mathrm{~mm}$.; breadth $1.60 \mathrm{~mm}$.; thickness $0.85 \mathrm{~mm}$.

This beautiful species is only mentioned by Parker and Jones in 1864 and is first figured and described by H. B. Brady, Parker, and Jones in 1870. The species is discussed in detail in our paper on the Polymorphinidae found in Japan.

Distribution.- It is one of the most abundant species in warm seas of the Australian region extending into the Philippine region, where it is abundant, but not as far north as Japan, where it is replaced by Sigmoidella kagaensis Cushman and Ozawa. It occurs in the late Tertiary of the Australian and East Indian region. It is also com- 
mon in the Tertiary of Trinidad, where numerous other species now living in the Indo-Pacific are found fossil. Our specimens represent the following localities:

Recent.-Pacific, Philippine expedition, Albatross D5143, vicinity of Jolo, 19 fathoms; D5145, off Jolo, 23 fathoms; D5146, 24 fathoms, D5148, 17 fathoms, both Sulu Archipelago, vicinity of Siasi; D5151, 24 fathoms, D5152, 34 fathoms, both Sulu Archipelago, off Tawi Tawi Group; D5178, 78 fathoms, D5179, 37 fathoms, both off Romblon; D5282, 248 fathoms, China Sea, off southern Luzon; D5318, 340 fathoms, China Sea, off Formosa; D5569, 303 fathoms, north of Tawi Tawi; D5580, 162 fathoms, Darvel Bay, Borneo; D2668, 9 fathoms, off Hongkong; Dusky Sound, New Zealand.

Pliocene.-Saloenia, Benkoelan, Sumatra.

Miocene.-Australia, Balcombian, lower beds, Muddy Creek, Victoria. Janjukian, soapy clay bed in polyzoal limestone, Danger Point, Torquay, Victoria. Green marl, Bird Rock cliffs, Torquay, Victoria; Filter Quarry, Batesford, Victoria. Trinidad, "Sagrina beds," Orapouche Lagoon, Trinidad Point; "Uvigerina bed," Cipero section; from oil-stained shales, just north of Point Bontour.

Oligocene.-Australia, Clifton Bank near Hamilton, Victoria.

Eocene.-Trinidad, Cipero section and Mount Moriah beds, yellow sandy clay, underlying orbitoidal limestone, Vistabella quarry.

\section{SIGMOIDELLA KAGAENSIS Cushman and Ozawa}

Plate 39, figures 2, 5

Sigmoidella kagaensis Cushman and Ozawa, Contr. Cushman Lab. Foram. Res., vol. 4, 1928, p. 19, pl. 2, fig. 14; Jap. Journ. Geol. \& Geogr., vol. 6, 1929 , p. 76 , pl. 13 , fig. 15 ; pl. 16 , fig. 9 .

Polymorphina elegantissima H. B. Brady, PARKer, and Jones, Trans. Linn. Soc., vol. 27,1870 , p. 231 , pl. 40 , fig. 15 a.

Test broadly ovate, base very broadly rounded, apertural end somewhat tapering, sides nearly parallel for more than half the length, compressed, periphery subacute; chambers elongate, narrow, five or six times as long as broad, arranged in an open, clockwise sigmoid form, resulting in a test in which, when viewed from either side, one elongate chamber appears at the left and all other visible chambers are in a series of gradually increasing length on its right, and involute; sutures very distinct, curved, not depressed, except on the growing edge, which is depressed; wall smooth, translucent; aperture terminal, radiate.

Length of holotype $1.50 \mathrm{~mm}$; breadth 0.70 .; thickness $0.34 \mathrm{~mm}$.

The arrangement of the chambers in the species is in many ways similar to that seen in Sigmoilina in the Miliolidae except that the aperture is always at one end. It is closely related to Sigmoidella elegantissima, but is a more elongate and narrow form and probably 
represents a cool water relative of Sigmoidella elegantissima (Parker and Jones).

Distribution.-Our specimens represent the following localities:

Recent.-Off Japan, Kobama (abundant). Albatross D4883, 53 fathoms, about 20 miles southwest of Nagasaki entrance, Eastern Sea; Inland Sea. Philippines, D5143, 19 fathoms, off Jolo Jolo; D5311, 88 fathoms, China Sea, near Hongkong.

Pleistocene.-Japan, Alluvium, Kehi, Province of Tajima.

Pliocene.-Upper, Japan, Kumomya, Province of Totomi; Okuwa, Province of Kaga; Ono, Province of Kochi; Natsukawa, Province of Echigo. Lower Pliocene, Beaumaris, near Melbourne, Victoria, Australia.

Miocene.-Australia, Janjukian, polyzoal marl, overlying limestone, Filter quarries, Batesford, Victoria.

Sigmoidella PLUMMeraE Cushman and Ozawa, new species

Plate 39, figures $3 a, b$

Test compressed, ovate, broadly rounded at the base, acute toward the aperture, periphery angular; chambers elongated, more or less compressed, arranged in a contraclockwise sigmoid series, each succeeding chamber embracing the earlier one, but often the last chamber not extending down to the initial end; sutures not depressed, usually distinct; wall rather thin, smooth; aperture radiate.

Length of holotype $0.70 \mathrm{~mm}$.; breadth $0.35 \mathrm{~mm}$.; thickness 0.22 $\mathrm{mm}$.

Holotype-(Cushman Coll. No. 11879.) From the Eocene, Cooks Mountain formation, Smithville, Tex.

The main difference between the present species and Sigmoidella elegantissima is the sigmoid arrangement of chambers, that of the present species being contraclockwise, while that of S. elegantissima is clockwise.

Distribution.-It is common in the Eocene in the United States, especially in the Claiborne, but ranges from the Cooper marl to the Midway. We have it from numerous localities from South Carolina to Texas. The species is named for Mrs. Helen J. Plummer.

SIGMOIDELLA MARGARETAE Cushman and Ozawa, new species

Plate 39 , figures $4 a, b$

Test much compressed, ovate in outline, periphery very angular; chambers compressed, elongated, arranged in a contraclockwise sigmoid series, each succeeding chamber extending down to the base and embracing the earlier ones; sutures not depressed, distinct; wall smooth, rather thin; aperture radiate.

Length of holotype $0.50 \mathrm{~mm}$.; breadth $0.25 \mathrm{~mm}$.; thickness $0.10 \mathrm{~mm}$. 
Holotype.-(Cushman Coll. No. 11882.) From the upper Pliocene of Terao Miura, Japan. We have a single specimen from Albatross D4807 off Japan.

In its contraclockwise sigmoid arrangement of chambers and the general outline of the test it is similar to Sigmoidella plummerae from the Eocene of North America. However, compared with the American species, it is much more compressed, with a very angulate periphery and a thinner wall.

When we described Sigmoidella elegantissima in our recent paper we remarked that we had examined very many specimens which showed the sigmoid series of chambers clockwisely arranged, and a single specimen was found with a contraclockwise arrangement. Now we are convinced that this single specimen is not Sigmoidella elegantissima, but is quite distinct from that species in its much compressed test and more acute apertural end. This determination is confirmed by the occurrence of specimens having a contraclockwise arrangement of chambers in the Japanese late Tertiary.

The specific name is given for Miss Margaret $\mathrm{S}$. Moore, who made all the drawings for the figures in this paper.

\section{Genus GLANDULINA d'Orbigny, 1826}

\section{GLANDULINA LAEVIGATA d'Orbigny}

Plate 40, figures $1 a, b$

Nodosaria (Glandulina) laevigata D'ORBigny, Ann. Sci. Nat., vol. 7, 1826, p. 252, No. 1, pl. 10, figs. 1-3.

Glandulina laevigata D'Orbigny, Foram. Foss. Bass. Tert. Vienne, 1846, p. 29, pl. 1, figs. 4, 5 .

Test fusiform the initial end very acute and often with spine in the microspheric form, obtuse in the megalospheric form, circular in cross section; chambers inflated, much overlapping, arranged at first in a biserial series, abruptly becoming uniserial in the microspheric form, entirely uniserial in the megalospheric form; sutures not depressed, distinct; wall smooth, rather thick; aperture radiate.

There are at least two kinds of Glandulina; this one is derived from Pyrulina, and the other from Marginulina. Therefore it is almost impossible to give any synonymy without examining the actual specimens. D'Orbigny listed the present species from the Adriatic Sea, Tertiary of the environs of Siena, and Tertiary of the Vienna Basin. We have examined abundant specimens from the last two localities and found that d'Orbigny's G. laevigata is evidently related to Pyrulina. Such specimens figured by d'Orbigny in the Tableau and also in the Vienna Basin monograph have invariably an early stage consisting of biserial chambers. 
Plate 40 , figures $2 a, b$

Psecadium acuminatum Reuss, Sitz. Akad. Wiss. Wien, vol. 62, pt. 1, 1870, p. 478.-v. Schlicht, Foram. Pietzpuhl, 1870, pl. 25, figs. 1-10.

Test elongate, fusiform to cylindrical, circular in section, greatest breadth near the apertural end, distinctly acute toward the initial end; chambers rounded, arranged in an entirely uniserial series; sutures not depressed, distinct; wall smooth, translucent; aperture often with an entosolenian tube, which is visible from the exterior, radiate.

Length of holotype $0.43 \mathrm{~mm}$.; breadth $0.18 \mathrm{~mm}$.

Holotype--(Cushman Coll. No. 11884.) From the Oligocene of Pietzpuhl, Germany.

The present species is fairly well figured by $v$. Schlicht under the name of Atractolina, to which Reuss gave the name Psecadium acuminatum, but we include it in Glandulina. The name acuminata is preoccupied by d'Orbigny, and accordingly the new specific name reussi is proposed.

Distribution.-We have only a single specimen from the Oligocene of Pietzpuhl, Germany, the type locality.

\section{GLANDULINA DIMORPHA (Bornemann)}

\section{Plate 40, figures 3-5}

Guttulina dimorpha Bonnemann, Zeitschr. deutsch. geol. Gesell., vol. 7, 1855 , p. 345 , pl. 17 , fig. 5 .

Guttulina vitrea Bornemann, Zeitschr. deutsch. geol. Gesell., vol. 7, 1855, p. 346 , pl. 17 , fig. 8 .

Polymorphina proteiformis Reuss, Bull. Acad. Roy. Sci. Belg., ser. 2, vol. 15, 1863 , p. 151 , pl. 2 , figs. $30-35$ (not fig. 36 ; pl. 3 , figs. $37-40$ ).

Psecadium nussdorfensis Karrer, Abhandl. k. k. Geol. Reichs., vol. 9, 1877, p. 379 , pl. 16 b, fig. 23.

Polymorphina vitrea Bornemann var. glandulinoides Fornasini, Mem. Accad. Soc. Istit. Bologna, ser. 5, vol. 9, 1900-1902 (1902), p. 66, fig. 18 (in text).

Test fusiform (young microspheric form) to cylindrical (adult), acuminate (microspheric) or rounded (megalospheric) at the initial end; chambers inflated, arranged in a nearly triserial series in the young, becoming uniserial later in the microspheric form, or entirely uniserial, but not regularly so in the megalospheric form; sutures slightly depressed, generally distinct; wall smooth; aperture radiate.

Maximum length $1.20 \mathrm{~mm}$; d diameter $0.44 \mathrm{~mm}$.

The present species is undoubtedly derived from Pyrulina fusiformis. The early stage of the microspheric form of Glandulina dimorpha resembles Pyrulina fusiformis, yet its septa even in the young state tend to be placed at right angles to the exterior wall. 
Guttulina vitrea (Bornemann) has the acute initial end and its septa becoming parallel to each other; however, it may represent the microspheric form of the present species.

Polymorphina glandulinoides Fornasini is undoubtedly a typical microspheric form.

The first figure of Polymorphina proteiformis Reuss, as well as Psecadium nussdorfensis, is characterized by the rounded initial end and almost parallel septa. They are considered to represent the megalospheric form of the present species.

Distribution.-We have specimens from the upper Oligocene of Ahnatal, near Cassel, Germany, and from the Miocene of Nussdorf in the Vienna Basin.

$92709-30-10$ 


\section{EXPLANATION OF PLATES}

\section{Plate 1}

Fig. 1. Eoguttulina polygona (Terquem). $\times 80$. From Jurassic, Kimmeridge clay, Ely, England. $a, b$, side views; $c$, basal view.

2. Eoguttulina liassica (Strickland). $\times 80$. From Jurassic, lower Lias, Chettenham, Gloucestershire, England. $a, b$, side views; $c$, basal view.

3. Eoguttulina anglica Cushman and Ozawa. $\times 45$. From Cretaceous, Cambridge greensand, Saxon Cement Works, Cambridge, England. $a$, $b$, side views; $c$, basal view.

4. Quadrulina rhabdogonioides(Chapman). $\times 40$. (After Chapman.) Cretaceous, lower Greensand, Bargate beds of Surrey, Littleton, England. $a$, side view; $b$, apertural view.

5. Quadrulina frondicularioides (Chapman). $\times$ 45. (After Chapman.) Cretaceous, lower Greensand, Bargate beds of Surrey, Littleton, England. $a$, side view; $b$, apertural view.

6. Quadrulina lagenalis (Terquem). (After Terquem.) Lower Lias, Quenleu-les-Metz, France. $a$, side view; $b$, apertural view.

7, 8. Guttulina bulloides (Reuss). $\times 30 . \quad$ From Miocene of Pontlevoy, France. 7, Young specimen. $8 a, b$, side views; $8 c$ basal view.

9. Guttulina adhaerens (Olszewski). $\times$ 40. From Cretaceous, Chalkmarl, Saxon Cement Works, Cambridge, England. $a$. $b$, side views; $c$, basal view.

10. Guttulina bartschi Cushman and Ozawa. $\times$ 45. From Albatross D5178, 78 fathoms off Romblon, Philippines. $a$, $b$, side views; $c$, basal view. 


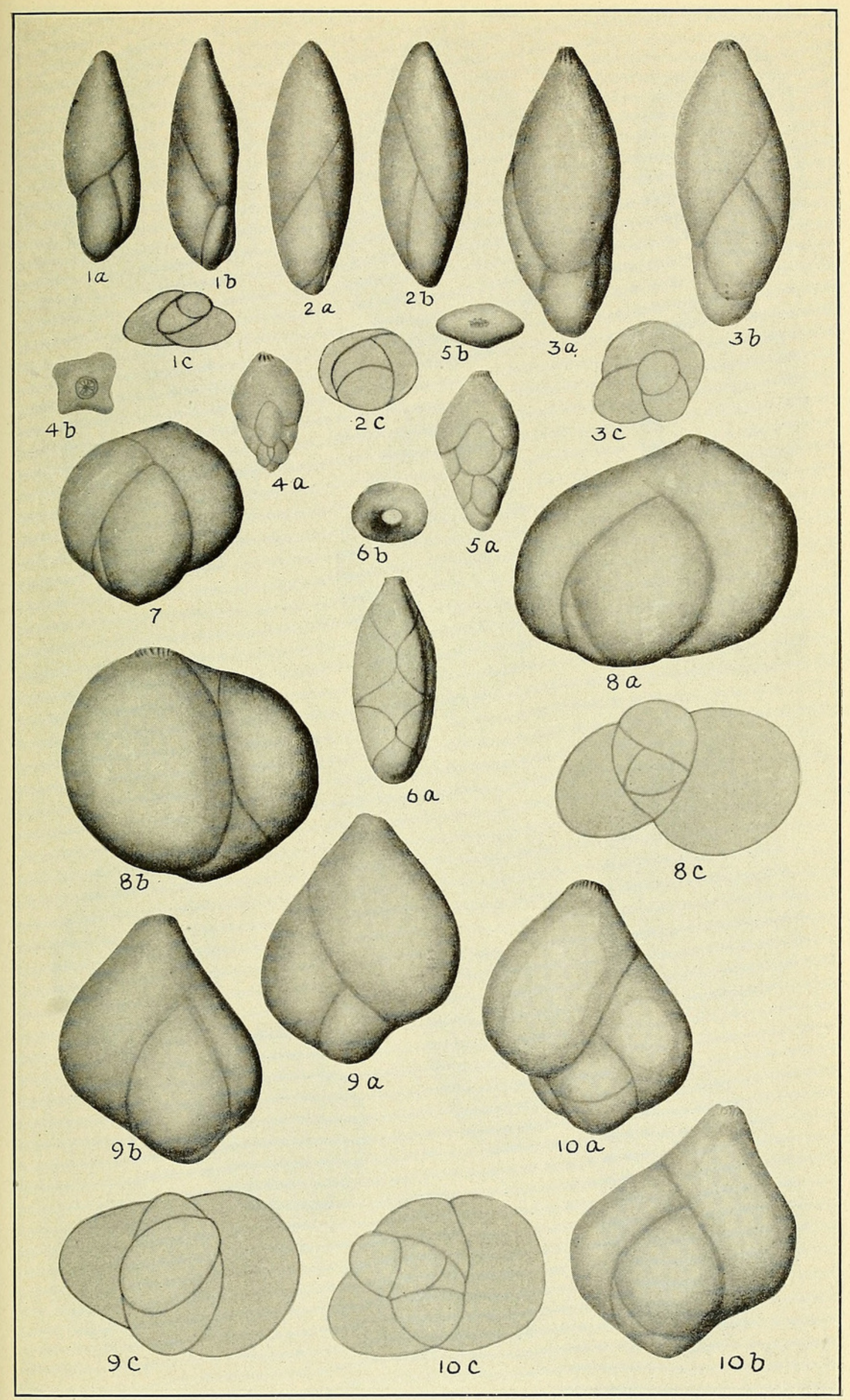

FORAMINIFERA OF THE FAMILY POLYMORPHINIDAE

FOR EXPLANATION OF PLATE SEE PAGE 146. 


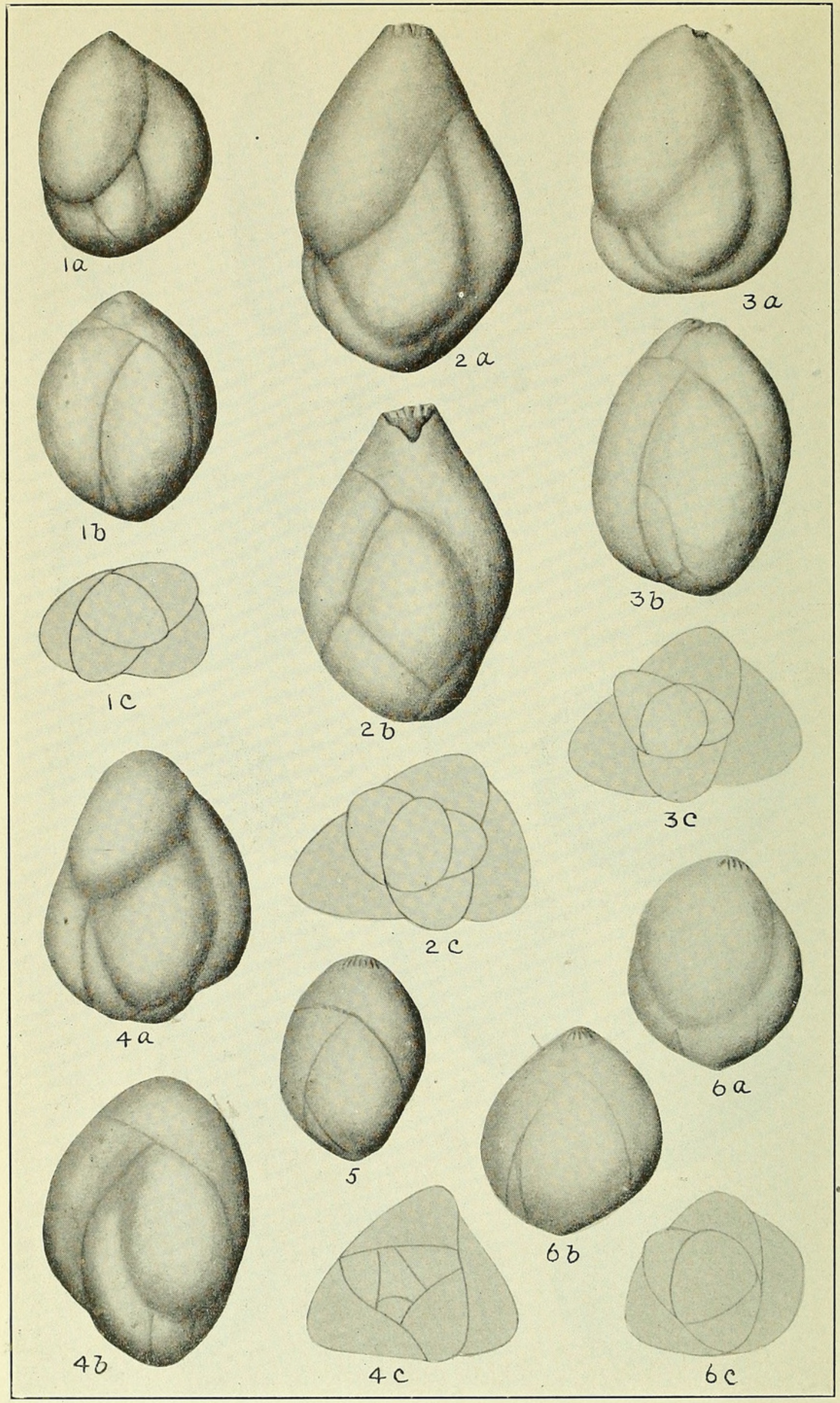

FORAMINIFERA OF THE FAMILY POLYMORPHINIDAE

FOR EXPLANATION OF PLATE SEE PAGE 147 


\section{Plate 2}

\section{All figures Guttulina problema d’Orbigny}

Figs. 1, 2. From Pliocene, Castel Arquato, Italy. $\times 45 . a, b$, side views; $c$, basal view.

3, 4. From Miocene, Burdigalien inferieur, Le Coquillat, Leognan, France. $\times 35$. $a, b$, side views; $c$, basal view.

5. From Upper Oligocene, Ahnatal, near Cassel, Germany. $\times 45$.

6. From Cretaceous, Flysch, Austria. $\times 35 . a, b$, side views; $c$, basal view. 
Plate 3

Figs. 1. Guttulina problema d'Orbigny. $\times 45 . \quad$ Pliocene, Stazzano, Italy. $a, b$, side views; $c$, basal view.

2, 3. Guttulina orientalis Cushman and Ozawa. $\times 35$. Pliocene, Sawane, Island of Sado, Japan. $a, b$, side views; $c$, basal view.

4, 5. Guttulina irregularis (d'Orbigny). Miocene, Tortonian, Amphistegina marl, Nussdorf, near Vienna, Austria. $a, b$, side views; $c$, basal view. 4, adult. $\times 25$. 5, young. $\times 35$.

148 


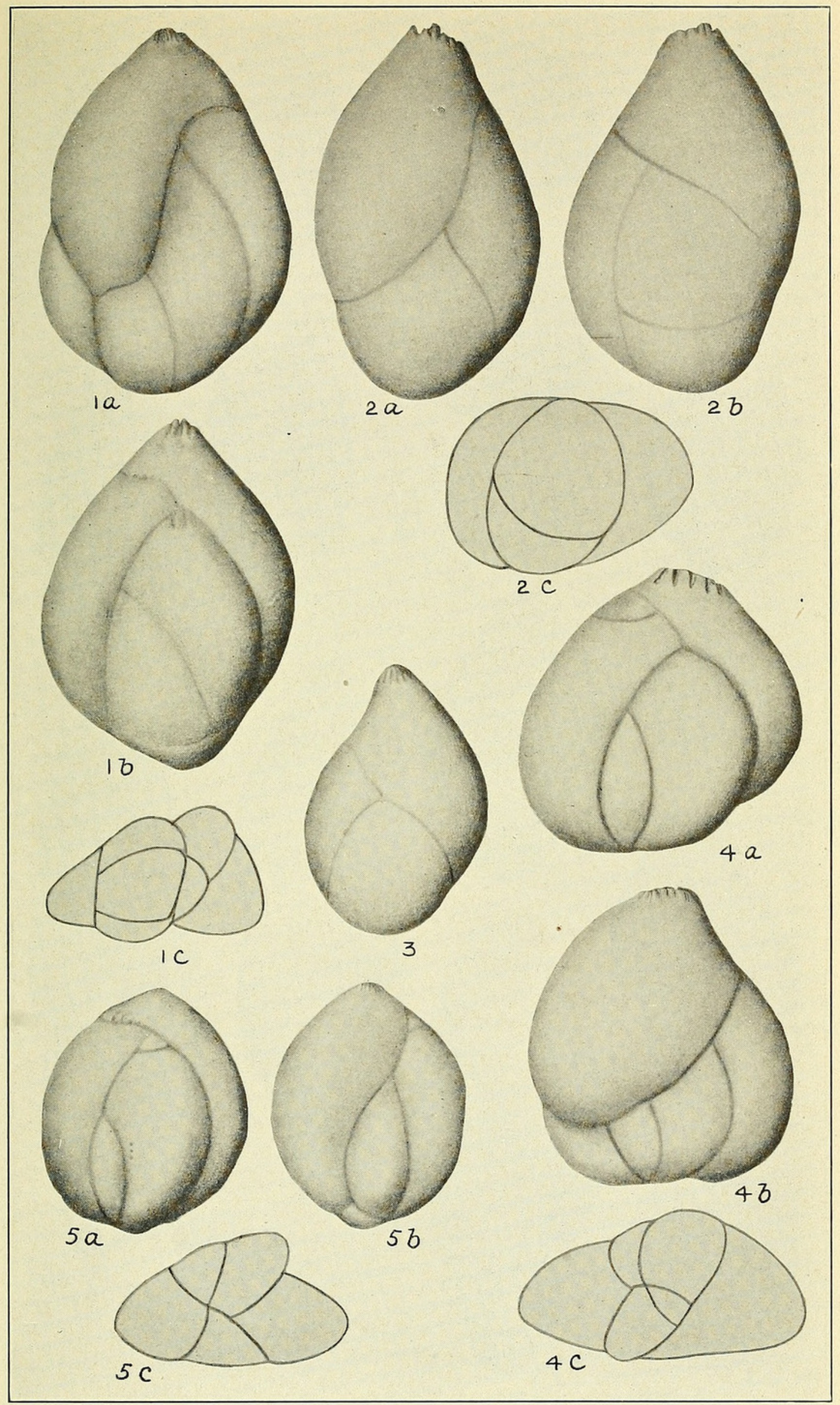

FORAMINIFERA OF THE FAMILY POLYMORPHINIDAE

FOR EXPLANATION OF PLATE SEE PAGE 148. 


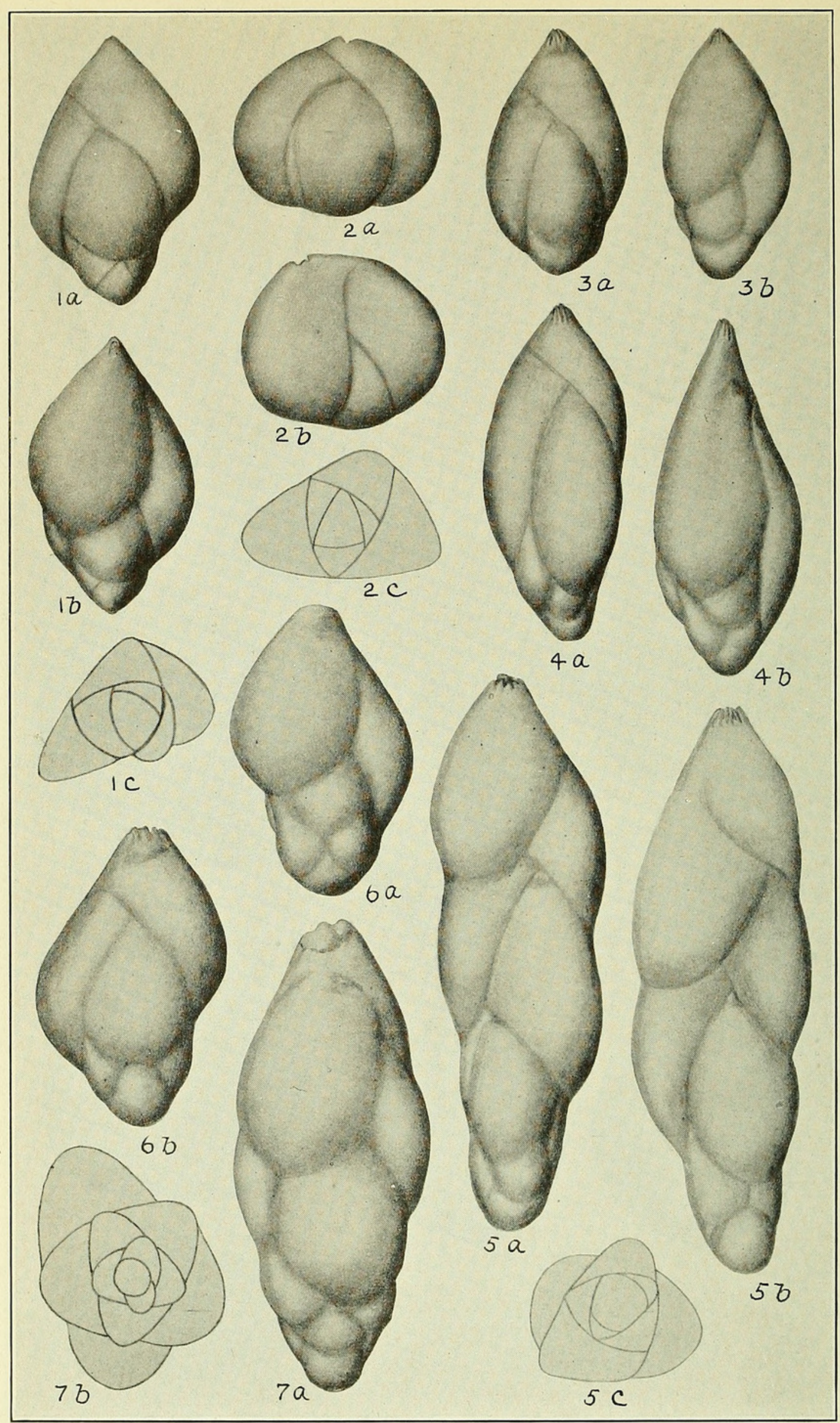

FORAMINIFERA OF THE FAMILY POLYMORPHINIDAE

FOR EXPLANATION OF PLATE SEE PAGE 149. 


\section{Plate 4}

Fig. 1. Guttulina frankei Cushman and Ozawa. $\times 45$. Middle Oligocene, Söllingen, Germany. $a, b$, side views; $c$, basal view.

2. Guttulina trigonula (Reuss). $\times 80$. Cretaceous, Lower Gault, Cambridge Brickyard, Cambridge, England. $a, b$, side views; $c$, basal view.

3-5. Guttulina austriaca d'Orbigny. $\times 45$. Miocene, brickyard of Baden, near Vienna, Austria. 3, 4, early stages. 5, adult. $a, b$, side views; $c$, basal view.

6, 7. Guttulina yabei Cushman and Ozawa. $\times 35$. Pliocene, Sawané, Island of Sado, Japan. $6 a, b$, side views of young specimen. 7, adult, $a$, side view; $b$, basal view. 
Plate 5

FIgs. 1, 2. Guttulina spicaeformis (Roemer). $\times 45$. Oligocene, Düsseldorf, Germany. $a, b$, side views; $c$, basal view.

3. Guttulina spicaeformis (Roemer) var. australis (d'Orbigny). $\times 45$. Recent, off Loggerhead Key, Dry Tortugas, Fla., 18 fathoms. $a, b$, side views; $c$, basal view.

4-6. Guttulina hantkeni Cushman and Ozawa. $\times 35$. Eocene, New Jersey. $4 a$, early stage; $b$, adult. 6 , holotype. Kleinzeller near Ofen, Hungary. Adult.

7. Guttulina pulchella d'Orbigny. $\times 45$. Recent, off Loggerhead Key, Dry Tortugas, Fla., 18 fathoms. $a, b$, side views; $c$, basal view. 


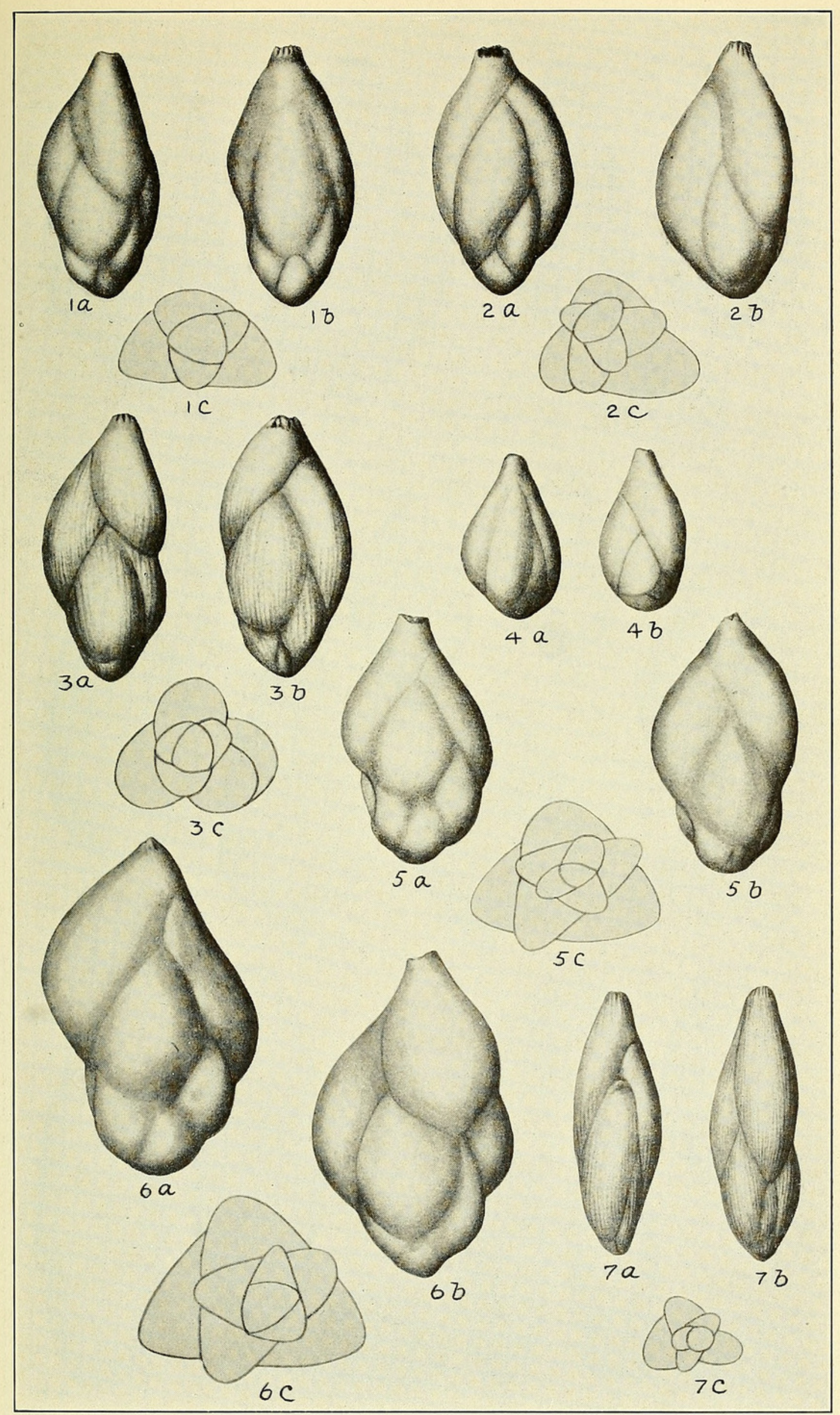

FORAMINIFERA OF THE FAMILY POLYMORPHINIDAE

FOR EXPLANATION OF PLATE SEE PAGE 150. 


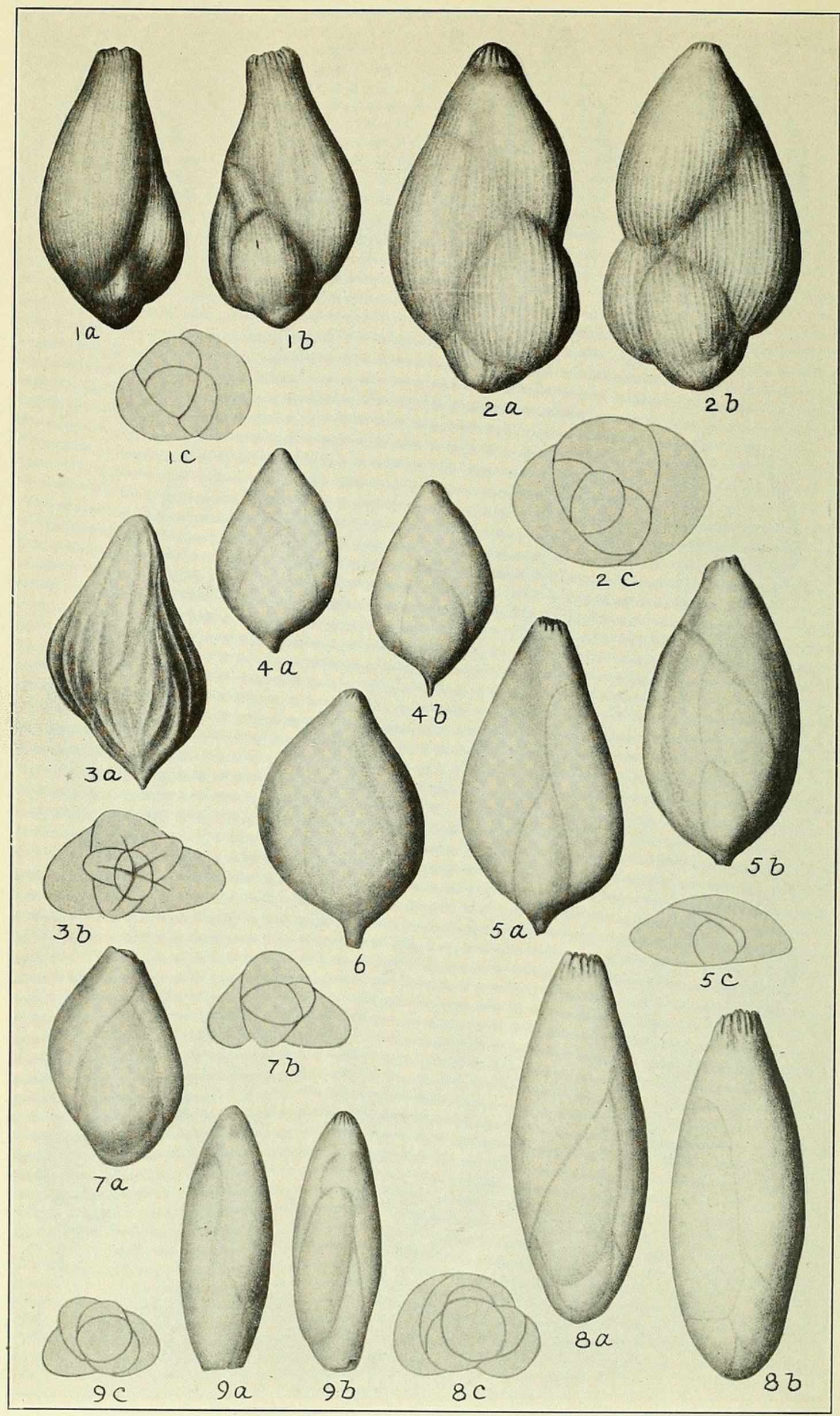

FORAMINIFERA OF THE FAMILY POLYMORPHINIDAE

FOR EXPLANATION OF PLATE SEE PAGE 151. 


\section{Plate 6}

Figs. 1, 2. Guttulina regina (H. B. Brady, Parker, and Jones). $\times 45 . \quad 1$, young specimen from Newcastle Beach, New South Wales. 2, adult from off Tawi Tawi Group, Philippines, 34 fathoms. $a, b$, side views; $c$, basal view.

3. Guttulina costatula Galloway and Wissler. $\times 65$. Pleistocene, Lomita Quarry, Palos Verdes Hills, California. $a$, side view; $b$, basal view.

4, 5. Guttulina caudata d'Orbigny. $\times 80$. 4, young specimen, Eocene, Lutetien moyen, Grignon, France. 5, older specimen, Eocene, Lutetien, Vaudancourt, France. $a, b$, side views; $c$, basal view.

6. Guttulina adhaerens (Olszewski) var. cuspidata Cushman and Ozawa, n. var. $\times 45$. Cretaceous, chalk marl, Folkestone, England.

7. Guttulina adhaerens (Olszewski). $\times 45$. Cretaceous, chalk marl, Folkestone, England. $a$, side view; $b$, basal view.

8. Guttulina praelonga (Egger). $\times 35$. Upper Oligocene, Ahnatal, near Cassel, Germany.

9. Guttulina guttiformis(Terquem). $\times 45$. Miocene, Burdigalien inferieur, Le Coquillat, Leognan, France. $a, b$, side views; $c$, basal view. 


\section{Plate 7}

FIgs. 1, 2. Guttulina irregularis (d'Orbigny). $\times 45$. Early stages, middle Oligocene, Hermsdorf, near Berlin, Germany. $a$, $b$, side views; $c$, basal view.

3. Guttulina irregularis d'Orbigny var. nipponensis Cushman and Ozawa, n. var. $\quad \times 45$. Upper Pliocene, Okuwa, Province of Kaga, Japan. $a, b$, side views; $c$, basal view.

4, 5. Guttulina jarvisi Cushman and Ozawa. $\times 30$. Eocene, Cipero section, Trinidad, British West Indies. 4, young. 5, adult. $a, b$, side views; $c$, basal view. 


$$
\begin{aligned}
& 0900 \\
& 000 \\
& 09
\end{aligned}
$$




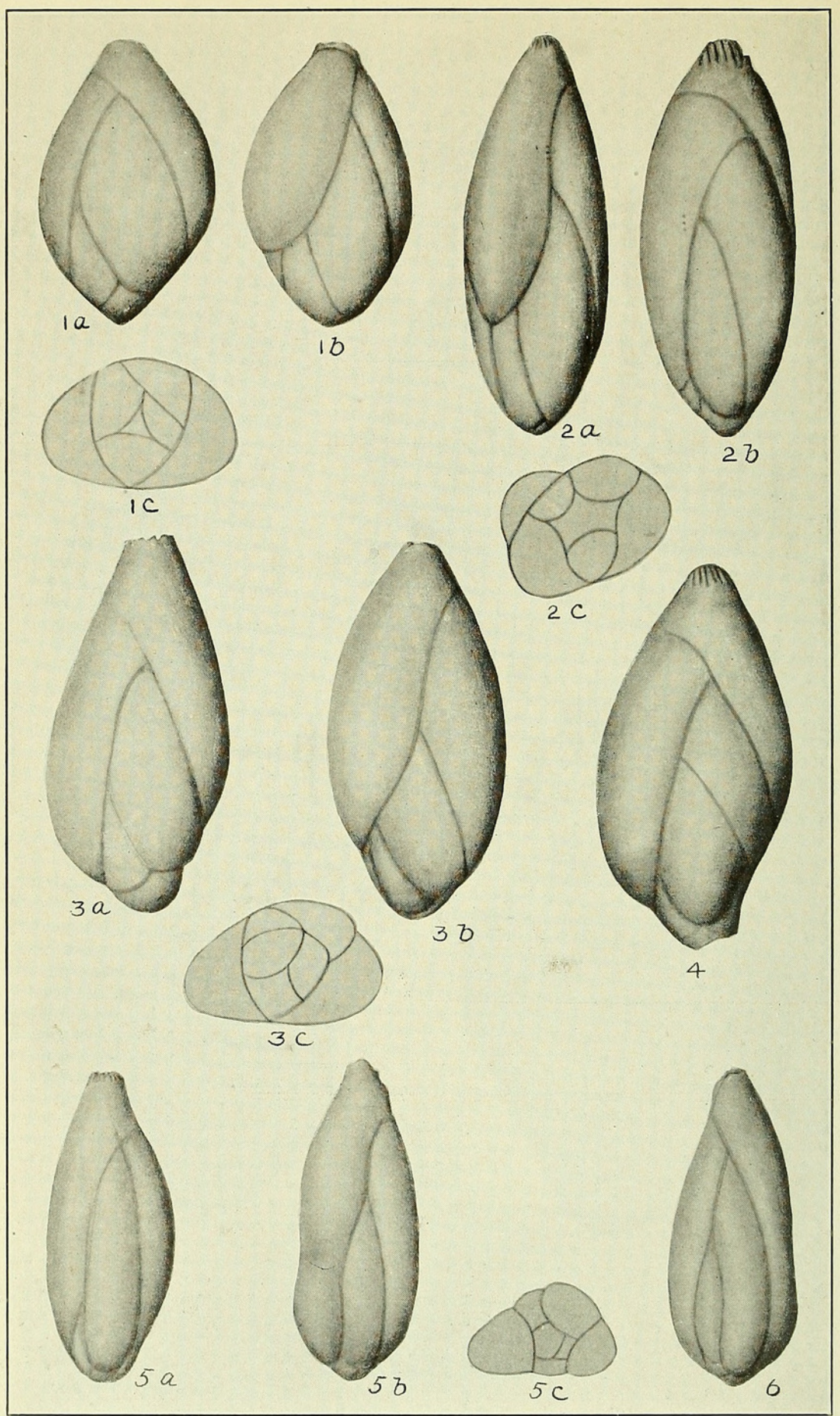

FORAMINIFERA OF THE FAMILY POLYMORPHINIDAE FOR EXPLANATION OF PLATE SEE PAGE 153. 


\section{Plate 8}

Figs. 1, 2. Guttulina lehneri Cushman and Ozawa. $\times 35$. Eocene, San Fernando, Trinidad, British West Indies. 1, young, 2, adult. Holotype.

3, 4. Guttulina yamazakii Cushman and Ozawa. $\times 35$. 3, upper Pliocene, Natsukawa, Province of Echigo, Japan. 4, holotype, from Albatros D4807, off Japan. $a, b$, side views; $c$, basal view.

5, 6. Guttulina kishinouyi Cushman and Ozawa. $\times 40$. Upper Pliocene, Natsukawa, Province of Echigo, Japan. 5, holotype. 6, paratype. $a, b$, side views; $c$, basal view. 
Plate 9

Figs. 1, 2. Guttulina baileyi Cushman and Ozawa. $\times 30 . \quad 1$, Holotype, Albatross D2416, coast of Carolina, 276 fathoms. 2, Albatross D5151, off Tawi Tawi Group, Philippines, 24 fathoms. $a$, $b$, side views; $c$, basal view.

3. Guttulina roemeri (Reuss). $\times 45$. Upper Oligocene, Ahnatal, near Cassel, Germany. $a, b$, side views; $c$, basal view.

4. Guttulina roemeri (Reuss) var. gigas (Karrer). $\times 60$. Miocene, Tortonian, Amphistegina marl, Grunes Kreuz, Nussdorf, near Vienna, Austria. $a, b$, side views; $c$, basal view.

154 


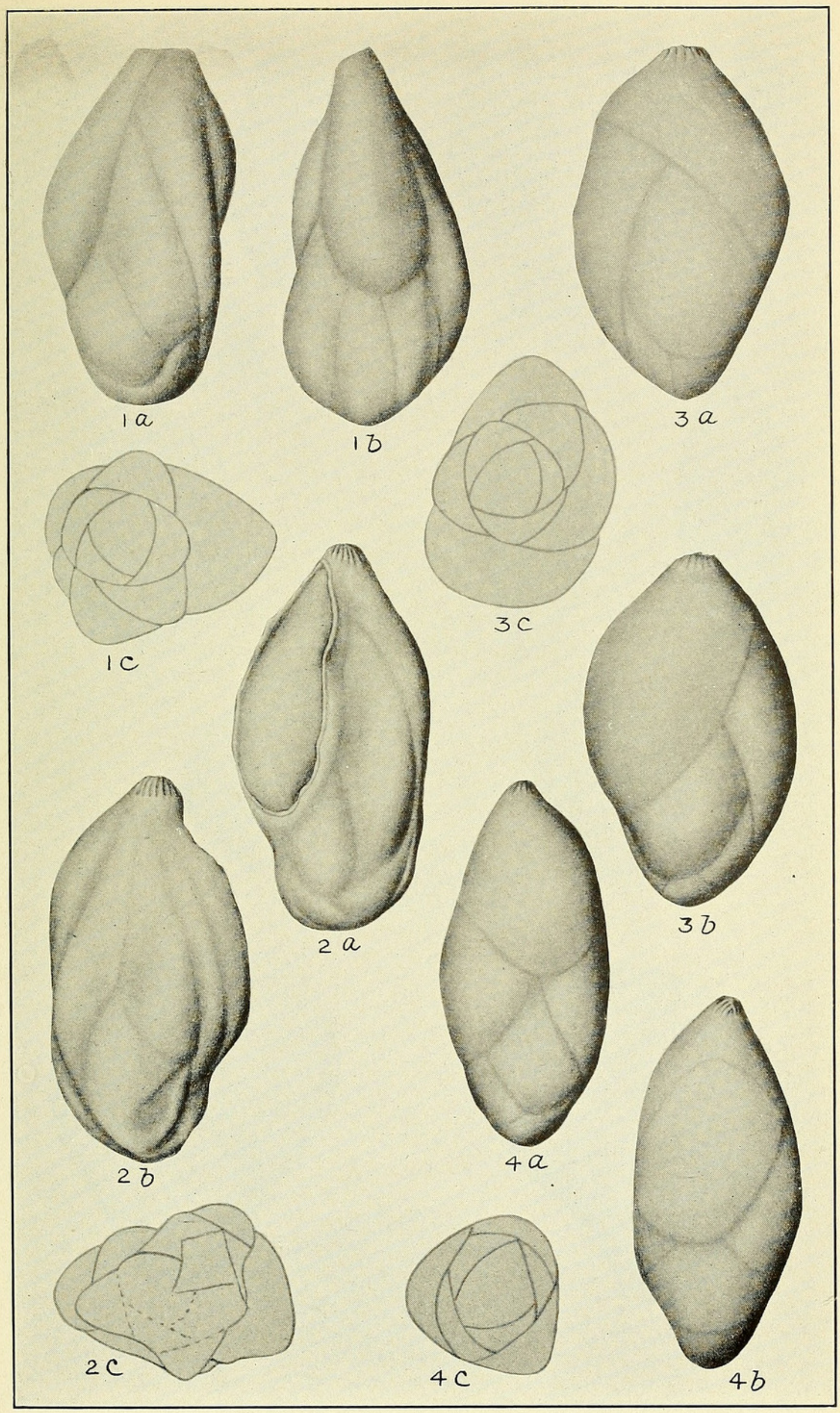

FORAMINIFERA OF THE FAMILY POLYMORPHINIDAE FOR EXPLANATION OF PLATE SEE PAGE 154. 


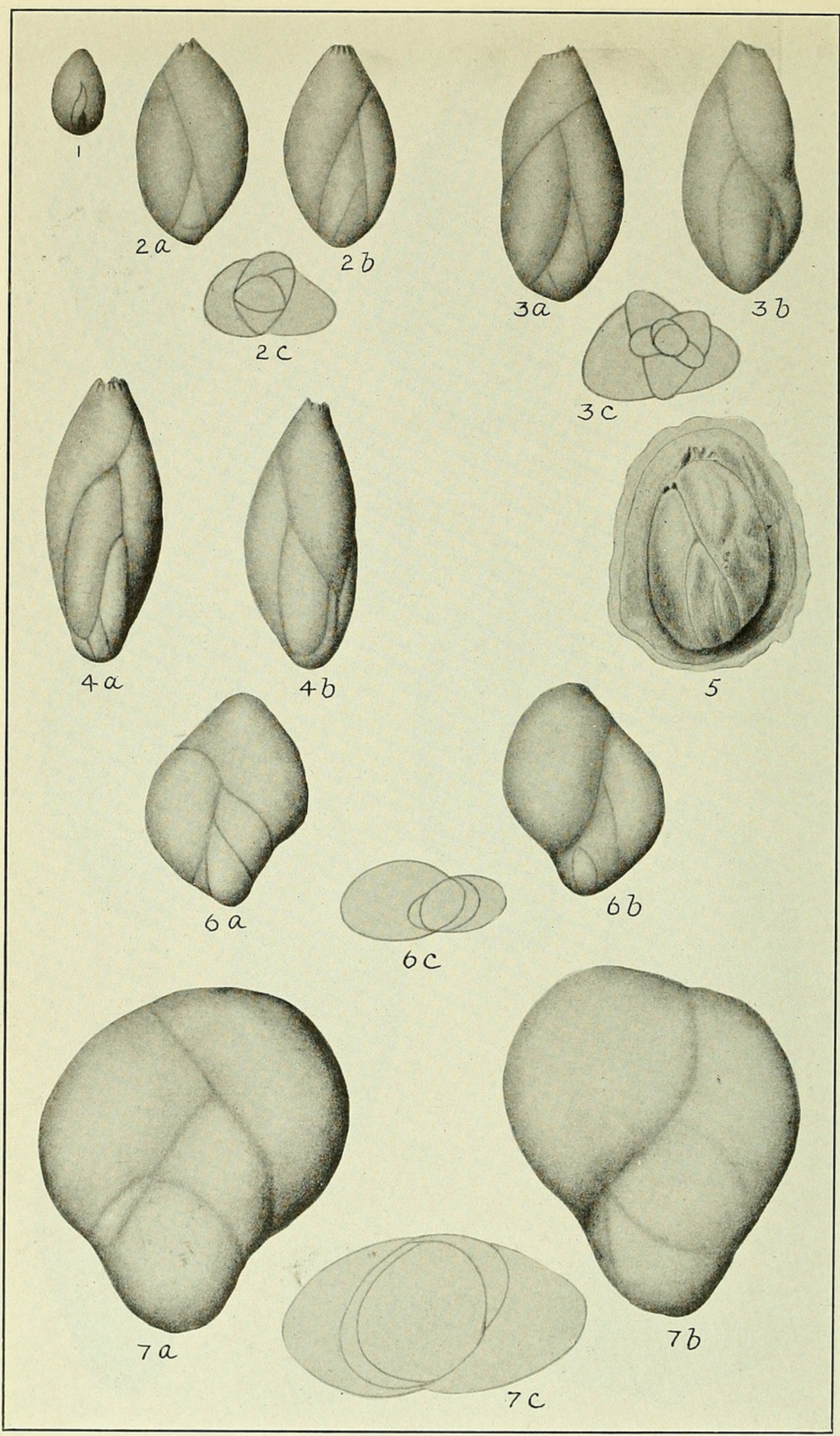

FORAMINIFERA OF THE FAMILY POLYMORPHINIDAE

FOR EXPLANATION OF PLATE SEE PAGE 155. 
Plate 10

Figs. 1-4. Guttulina lactea (Walker and Jacob). 1, copied from Walker and Jacob's original figure. 2-4, from off Bantry Bay, southwest Ireland, $37 \frac{1}{2}$ fathoms. $a, b$, side views; $c$, basal view.

5. Guttulina lactea (Walker and Jacob) var. earlandi Cushman and Ozawa, n. var. $\times 65$. Selsey Bill, England (After Heron-Allen and Earland).

6, 7. Pseudopolymorphina variata (Jones, Parker, and H. B. Brady) var. fischeri (Terquem). 6, adult. Pliocene, Crag, Sutton, England. $\times 30$. 7, young. $a, b$, side views; $c$, basal view. $\times 45$. Miocene, Burdigalien inferieur, Moulin de l'Eglise, Saucats, France. 
Plate 11

Fig. 1. Guttulina schafferi Cushman and Ozawa. $\times 45$. Tortonian, Amphistegina marl, Grunes Kreuz, Nussdorf, near Vienna, Austria. $a, b$, side views; $c$, basal view.

2. Guttulina woodsi Cushman and Ozawa. $\times 80$. Cretaceous, lower Gault, Barnwell pit, Cambridge, England.

3. Guttulina quinquecosta Cushman and Ozawa. $\times 45$. Plocene, Timms Point, San Pedro, Calif. $a, b$, side views; $c$, basal view.

4. Guttulina paalzowi Cushman and Ozawa. $\times 35$. Cretaceous, Maastricht, Holland. $a$, side view; $b$, basal view.

5. Guttulina regina (H. B. Brady, Parker, and Jones) var. crassicostata Cushman and Ozawa. $\times 45$. Lower Pliocene, Beaumaris, near Melbourne, Victoria, Australia. $a, b$, side views; $c$, basal view.

6. Guttulina emersoni (Bagg). $\times 25 . \quad$ (After Bagg.)

156 


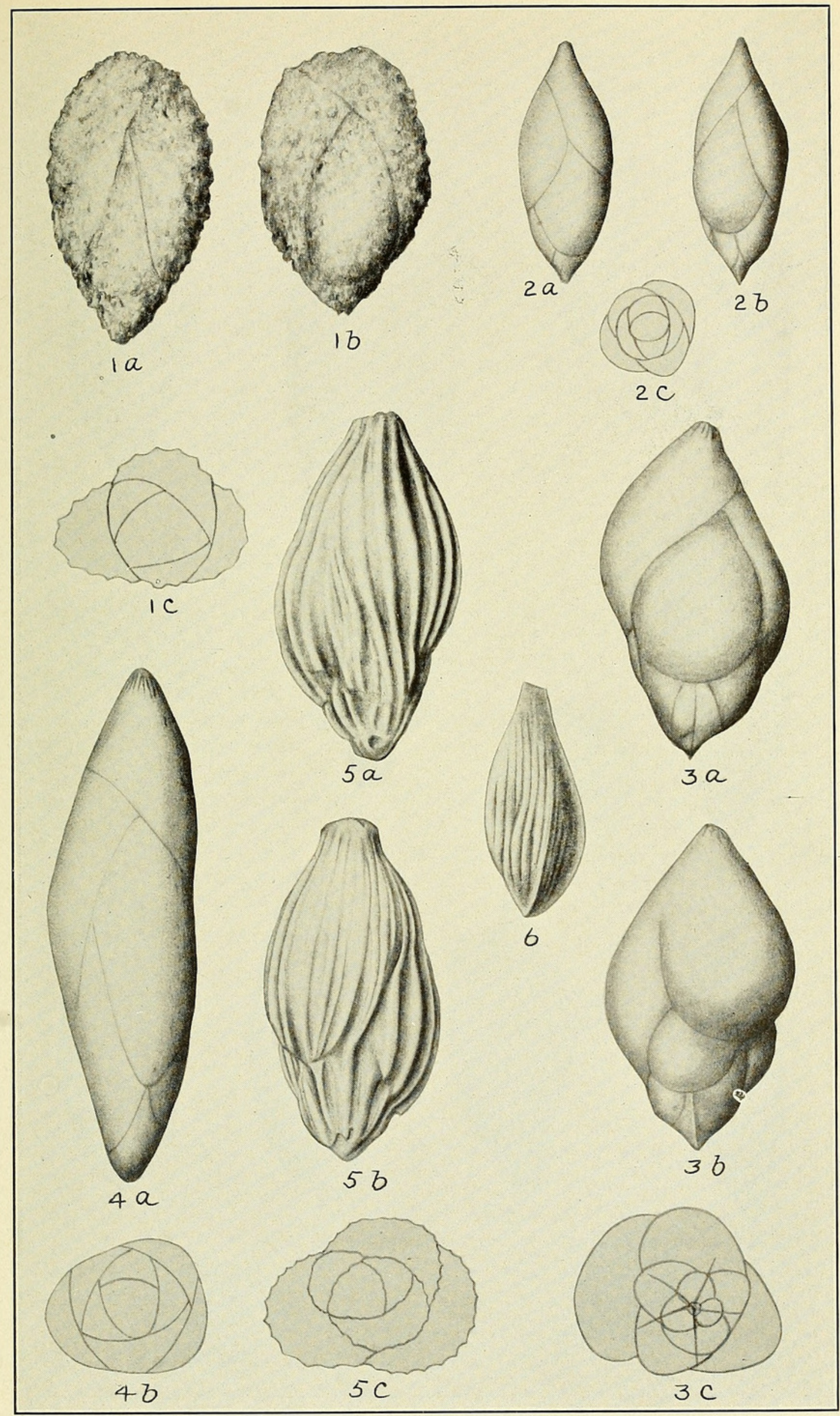

FORAMINIFERA OF THE FAMILY POLYMORPHINIDAE FOR EXPLANATION OF PLATE SEE PAGE 156. 


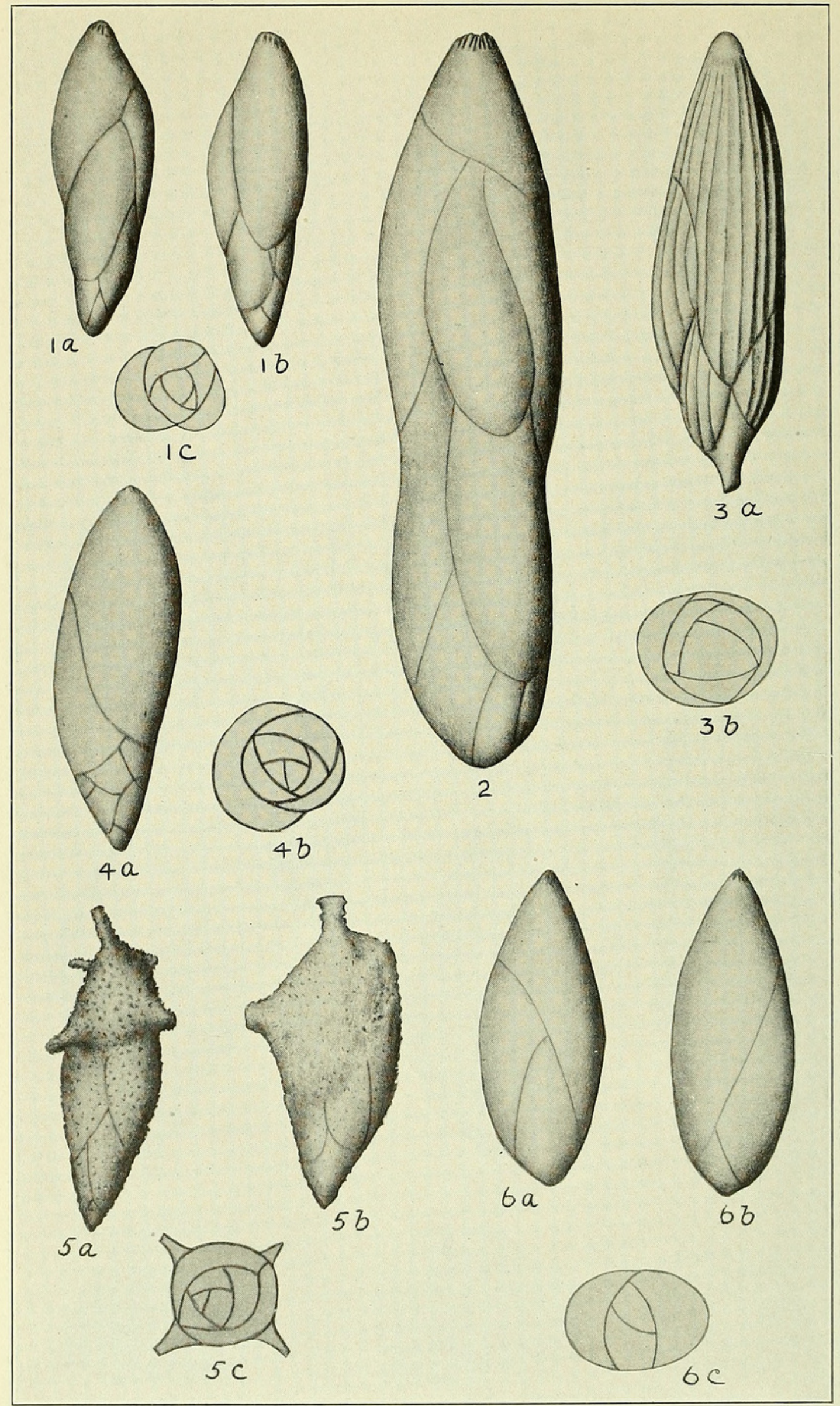

FORAMINIFERA OF THE FAMILY POLYMORPHINIDAE FOR EXPLANATION OF PLATE SEE PAGE 157. 
Figs. 1, 2. Guttulina dawsoni Cushman and Ozawa. $\times 35$. Gaspé Bay. 1, holotype. 2, abnormally large specimen occurring with the typical form. $a, b$, side views; $c$, basal view.

3. Guttulina costulata (Cushman). $\times 80$. Lower Oligocene, Mint Spring marl, Mint Spring Bayou, Vicksburg, Miss. a, side view; $b$, basal view.

4. Pyrulina labiata (Schwager). $\times 45$. Pliocene, Fiji. $a$, side view; $b$, basal view.

5. Pyrulina extensa (Cushman). $\times 45$. Pacific. a, Nero 1063, 1,884 fathoms. $b$, Nero 2061, 1,670 fathoms. $a, b$, side views; $c$, basal view.

6. Globulina prisca Reuss. $\times 65$. Cretaceous, Cambridge greensand, Saxon Cement Works, Cambridge, England. $a, b$, side views; c, basal view. 
Plate 13

Fig. 1. Pyrulina gutta d'Orbigny. $\times 45$. Lowest Eocene, Wansin, Belgium. $a, b$, side views; $c$, basal view.

2. Pyrulina vicksburgensis (Cushman). $\times 80$. Lower Oligocene, Mint Spring marl, at waterfall in Mint Spring Bayou, Vicksburg, Miss. $a, b$, side views; $c$, basal view.

3-8. Pyrulina fusiformis (Roemer). $\times 45$. Upper Oligocene. 3-5, Ahnatal, near Cassel, Germany. 3, 4, early stages. 5, adult. 6, young. Cretaceous, chalk marl, Saxon Cement Works, Cambridge, England. 7, 8, Miocene. Tortonian, brickyard at Baden, near Vienna, Austria. 158 


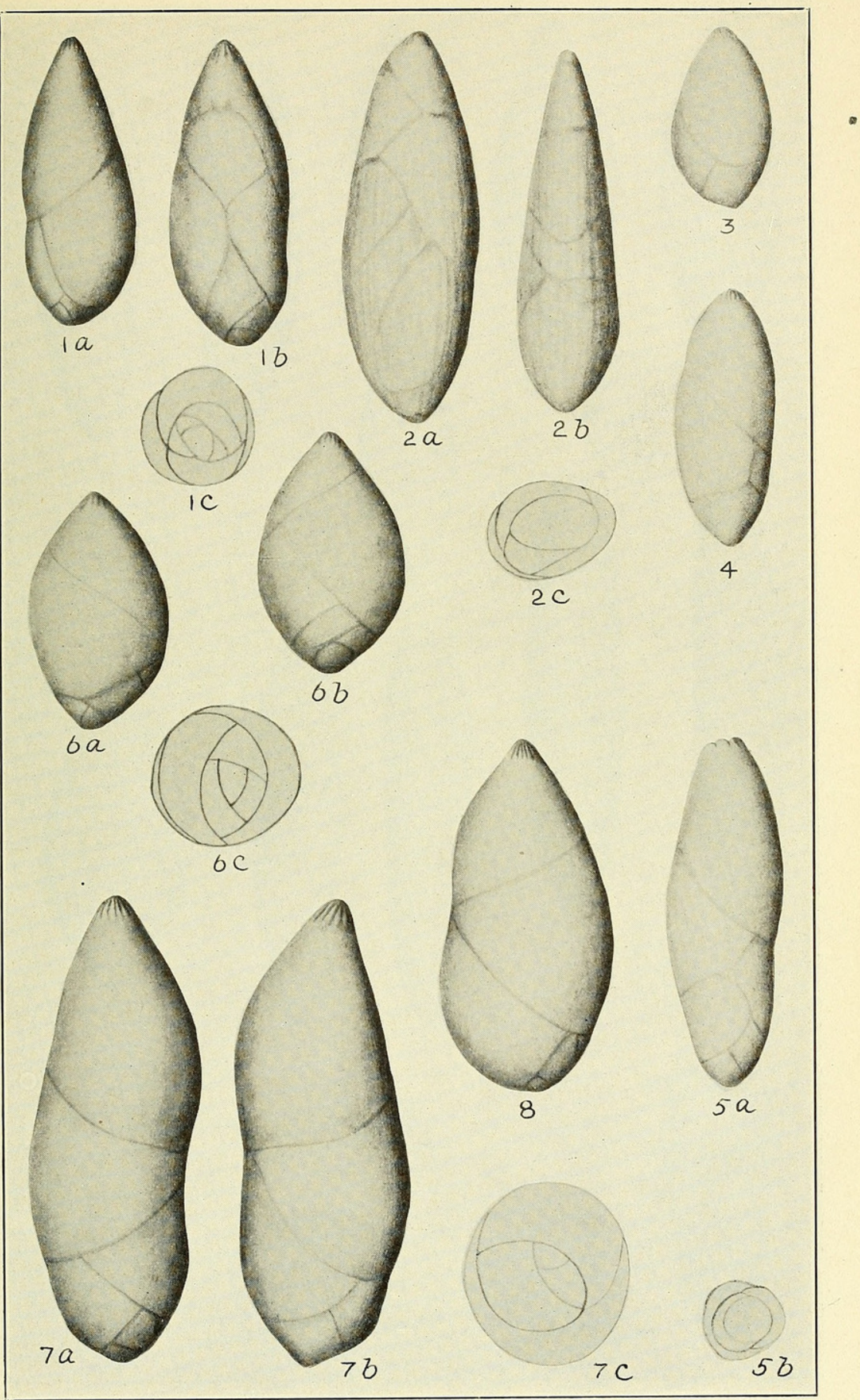

FORAMINIFERA OF THE FAMILY POLYMORPHINIDAE

FOR EXPLANATION OF PLATE SEE PAGE 158. 


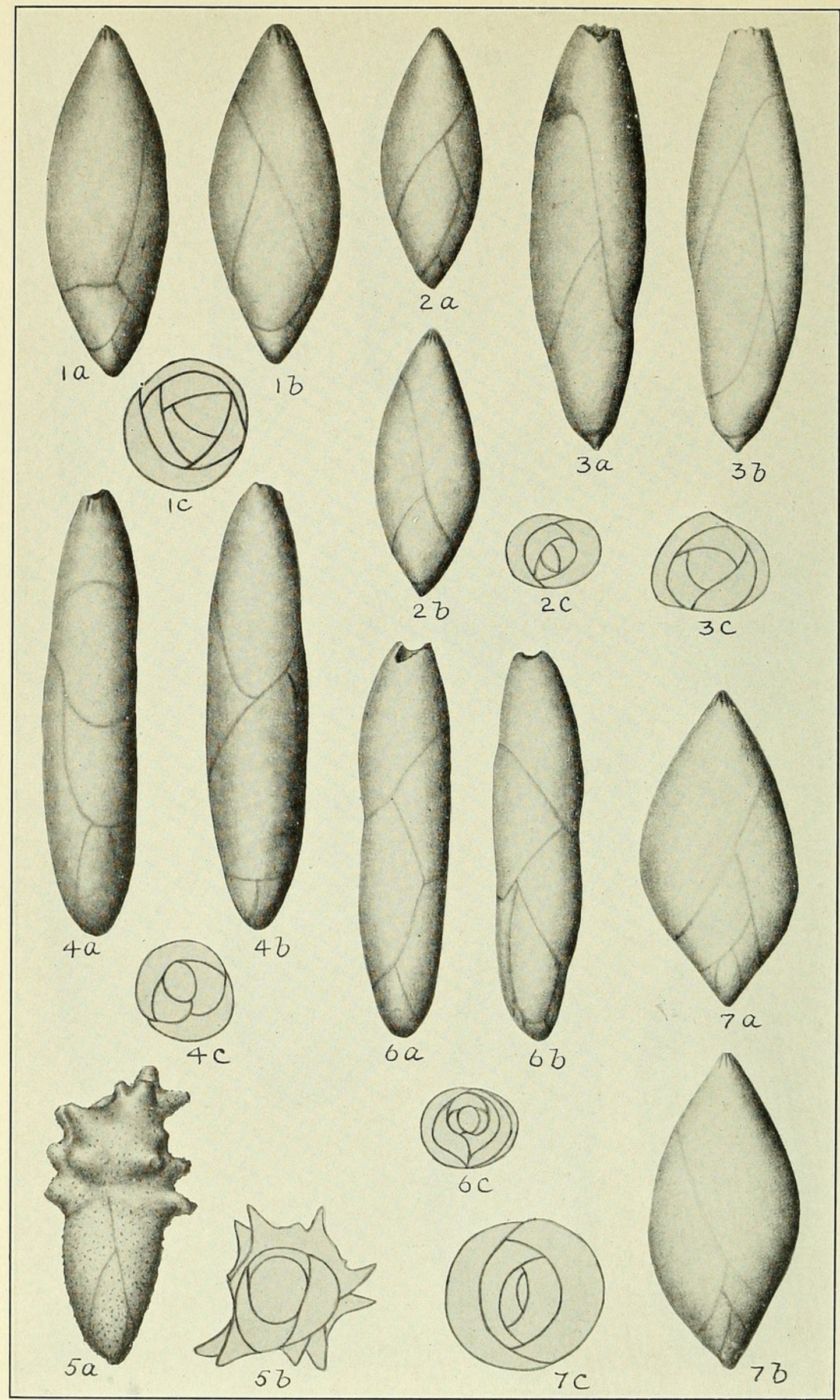

FORAMINIFERA OF THE FAMILY POLYMORPHINIDAE

FOR EXPLANATION OF PLATE SEE PAGE 159. 
Plate 14

Figs. 1-5. Pyrulina cylindroides (Ro€mer). 1; $\times 45$. Middle Oligocene, Hermsdorf, near Berlin, Germany. 2, $\times 80$. Cretaceous, lower Gault, Barnwell pit, Cambridge, England. 3, $\times 45$. Upper Oligocene, Ahnatal, near Cassel, Germany. 4, $\times 45$. a, Cretaceous, upper Senonian, Dasbeck; $b$, Hanover, Westphalia, Germany. $5, \times 45$. Fistulose form, Cretaceous, Cambridge greensand, Saxon Cement Works, Cambridge, England.

6. Pyrulina thouini (d'Orbigny). $\times 45$. Eocene, Lutetien moyen, Grignon, France. $a, b$, side views; $c$, basal view.

7. Pyrulina acuminata d'Orbigny. $\times 45$. Cretaceous, Craie blanc, Bougival, France. $a, b$, side views; $c$, basal view. 


\section{Plate 15}

Figs. 1-3. Pyrulina albatrossi Cushman and Ozawa. 1, $\times 25$. Albatross D2160, 167 fathoms, off Cuba. 2, 3, $\times 65$. Albatross D2756, 417 fathoms, off Brazil. 3, with an extra chamber.

4. Pyrulina reticulosa Cushman and Ozawa. $\times 45$. Off Japan, Albatross D4882, 248 fathoms. $a$, side view; $b$, basal view.

5. Globulina rotundata (Bornemann) var. pyrula (Fornasini). $\times 35$. (After type figure.) Pliocene, Siena, Italy.

6, 7. Globulina glacialis Cushman and Ozawa. $\times$ 65. Pleistocene, glacial clay, north side of the glen, near Montreal, Canada. 6, holotype, with an extra chamber. $a, b$, side views; $c$, basal view.

8. Guttulina semicostata (Marsson). $\times 30$. (After Marsson.) $a, b$, side views; $c$, apertural view.

9. Globulina landesi (G. D. Hanna and M. A. Hanna). $\times 65$. Recent, off Kobama, Province of Echizen, Japan. $a$, side view; $b$, basal view.

10. Globulina dentimarginata (Chapman). $\times 40$. (After Chapman.) a, outer surface; $b$, attached side.

160 


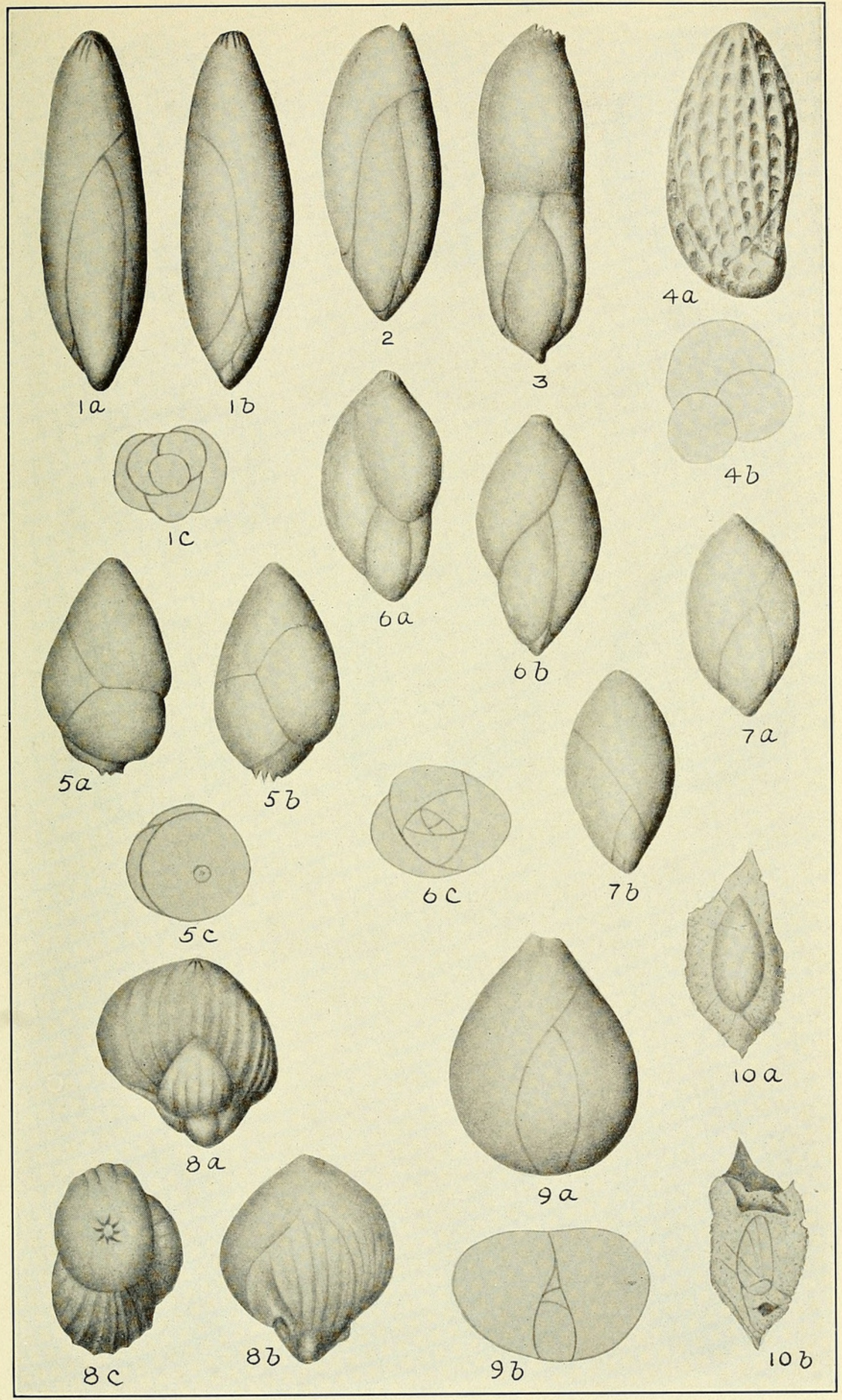

FORAMINIFERA OF THE FAMILY POLYMORPHINIDAE FOR EXPLANATION OF PLATE SEE PAGE 160. 


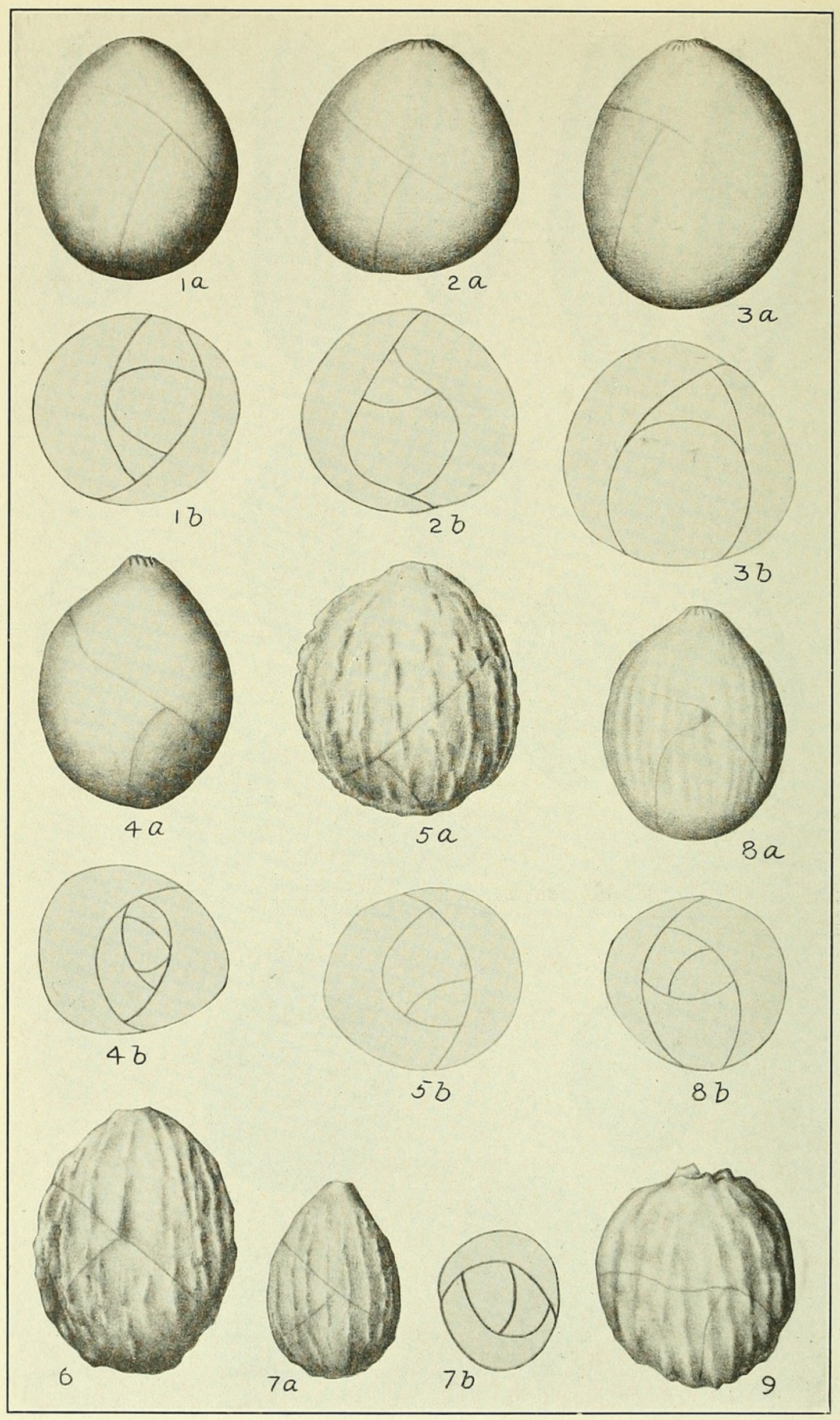

FORAMINIFERA OF THE FAMILY POLYMORPHINIDAE

FOR EXPLANATION OF PLATE SEE PAGE 161. 


\section{Plate 16}

Figs. 1-4. Globulina gibba d'Orbigny. 1, $\times 35$. Miocene, St. Paul de Dax, near Bordeaux, France. $2, \times 45$. Miocene, Tortonian, Amphistegina marl, Grunes Kreuz, Nussdorf, near Vienna, Austria. $3, \times 65$. Eocene, Lutetien, Grignon, France. 4, $\times 35$. Miocene, Perchtoldsdorf, near Vienna, Austria.

5-7. Globulina gibba d'Orbigny var. striata Egger. $\times 80 . \quad 5$, Drawn from Egger's paratype, from Miocene, near Ortenburg, Germany. 6, Miocene, Tortonian, Varpolata, Hungary. 7, Miocene, near Ortenburg, Germany.

8. Globulina gibba d'Orbigny var. myristiformis (Williamson). $\times 65$. From Lord Bandon dredgings, off southwest Ireland. a, side view; $b$, basal view.

9. Globulina gibba d'Orbigny var. ornata (Karrer). $\times 45 . \quad$ Miocene, Kostej, Banat, Hungary.

$92709-30-12$ 


\section{Plate 17}

Fig. 1. Globulina inaequalis Reuss var. spinata Cushman and Ozawa, $\times 80$. Upper Oligocene, Ahnatal, near Cassel, Germany.

2. Globulina gibba d'Orbigny var. verrucosa Cushman and Ozawa, $\times 80$. Eocene, Lutetien, Campbon, France. $a$, side view; $b$, basal view.

3. Globulina gibba d'Orbigny var. fissicostata Cushman and Ozawa. $\times 60$. Upper Oligocene, Ahnatal, near Cassel, Germany.

4, 5. Globulina gibba d'Orbigny var. punctata d'Orbigny. $\times 45.4$, Eocene, Lutetien, Grignon, France. 5, Miocene, Tortonian, Vosslau, near Baden, Vienna, Austria.

6, 7. Globulina gibba d'Orbigny var. tuberculata d'Orbigny. $\times 35 . \quad$ Miocene, Tortonian, Amphistegina marl, Grunes Kreuz, Nussdorf, Vienna, Austria.

8, 9. Globulina gibba d'Orbigny var. globosa (v. Münster). $\times 45.8$, Miocene, Tortonian, Amphistegina marl, Grunes Kreuz, Nussdorf, Vienna, Austria. 9, upper Oligocene, Ahnatal, near Cassel, Germany. 


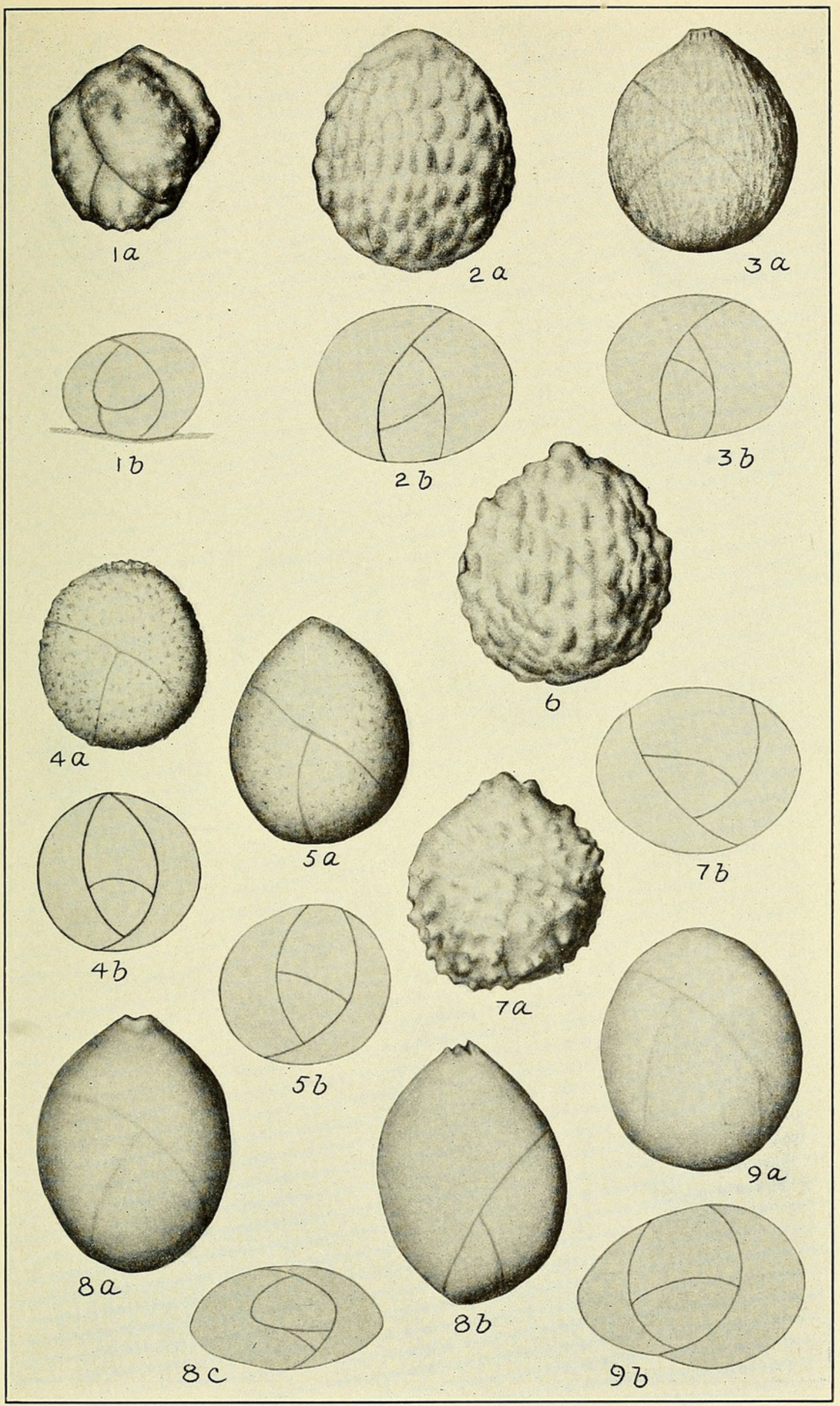

FORAMINIFERA OF THE FAMILY POLYMORPHINIDAE FOR EXPLANATION OF PLATE SEE PAGE 162 


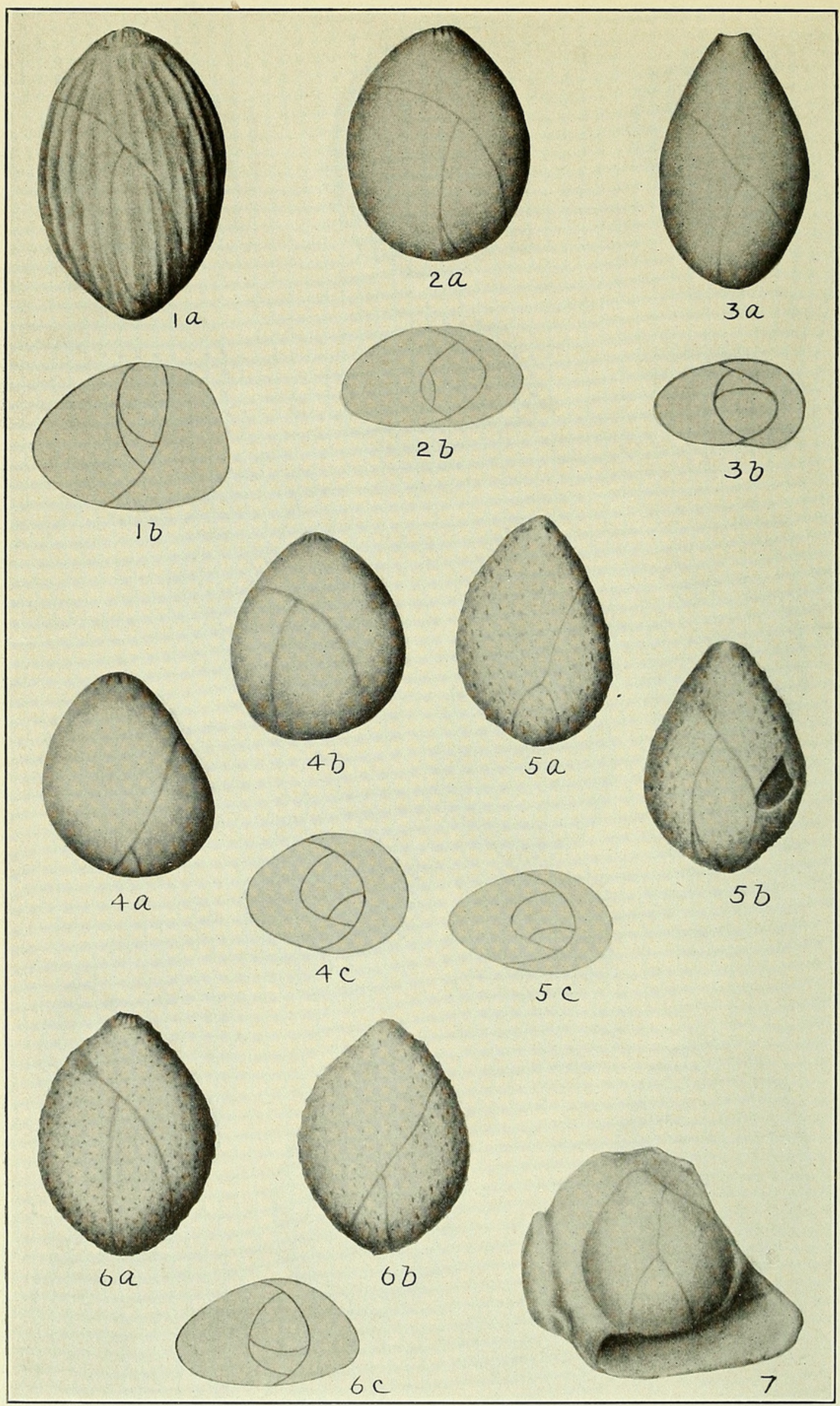

FORAMINIFERA OF THE FAMILY POLYMORPHINIDAE FOR EXPLANATION OF PLATE SEE PAGE 163. 


\section{Plate 18}

Fig. 1. Globulina gibba d'Orbigny var. longitudinalis Cushman and Ozawa, $\times$ 60. Pliocene, Castel Arquato, Italy. $a$, side view; $b$, basal view.

2-4. Globulina inaequalis Reuss. 2, $\times$ 45. Miocene, Tortonian sand, Strebersdorf, Bisamberg, near Vienna, Austria. $3, \times 65$. Eocene, Lutetien, Parnes (Les Bôves), France. 4, $\times 45$. Middle Oligocene, Hermsdorf, near Berlin, Germany.

5,6. Globulina inaequalis Reuss var. caribaea d'Orbigny. $\times 80 . \quad 5$, off Dry Tortugas, Fla., 12 fathoms. 6, Albatross D2150, Caribbean Sea, 382 fathoms.

7. Globulina inaequalis Reuss var. dollfussi Cushman and Ozawa, $\times 45$, Miocene, Burdigalien inferieur, Le Coquillat, Leognan, France. 
Plate 19

Figs. 1, 2. Globulina lacrima Reuss. 1, $\times 45$. Cretaceous, upper Senonian, Dasbeck, near Hanover, Westphalia Germany. 2, $\times 65$. Cretaceous, upper Senonian, Galling, near Siegsdorf, upper Bavaria, Germany.

3. Globulina lacrima Reuss var. horrida Reuss. $\times$ 80. Cretaceous, upper Senonian, Galling, near Siegsdorf, upper Bavaria, Germany.

4. Globulina lacrima Reuss var. ericia Cushman and Ozawa. $\times 45$. Cretaceous, chalk marl, Saxon Cement Works, Cambridge, England.

5-7. Globulina lacrima Reuss var. subsphaerica (Berthelin). $\times 80$. 5, 6, Cretaceous, chalk marl, Saxon Cement Works, Cambridge, England. 7, Cretaceous, lower Gault, Storey's Way, Cambridge, England.

8. Globulina gibba d'Orbigny var. cognata (Franzenau). $\times 45$. Pliocene, Sepik River, New Guinea. $a, b$, side views; $c$, basal view.

9. Globulina ampulla (Jones). $\times 80 . \quad$ Eocene, Bracklesham bed XVIII, White Cliff Bay, Isle of Wight, England. $a, b$, side views; $c$, basal view. 


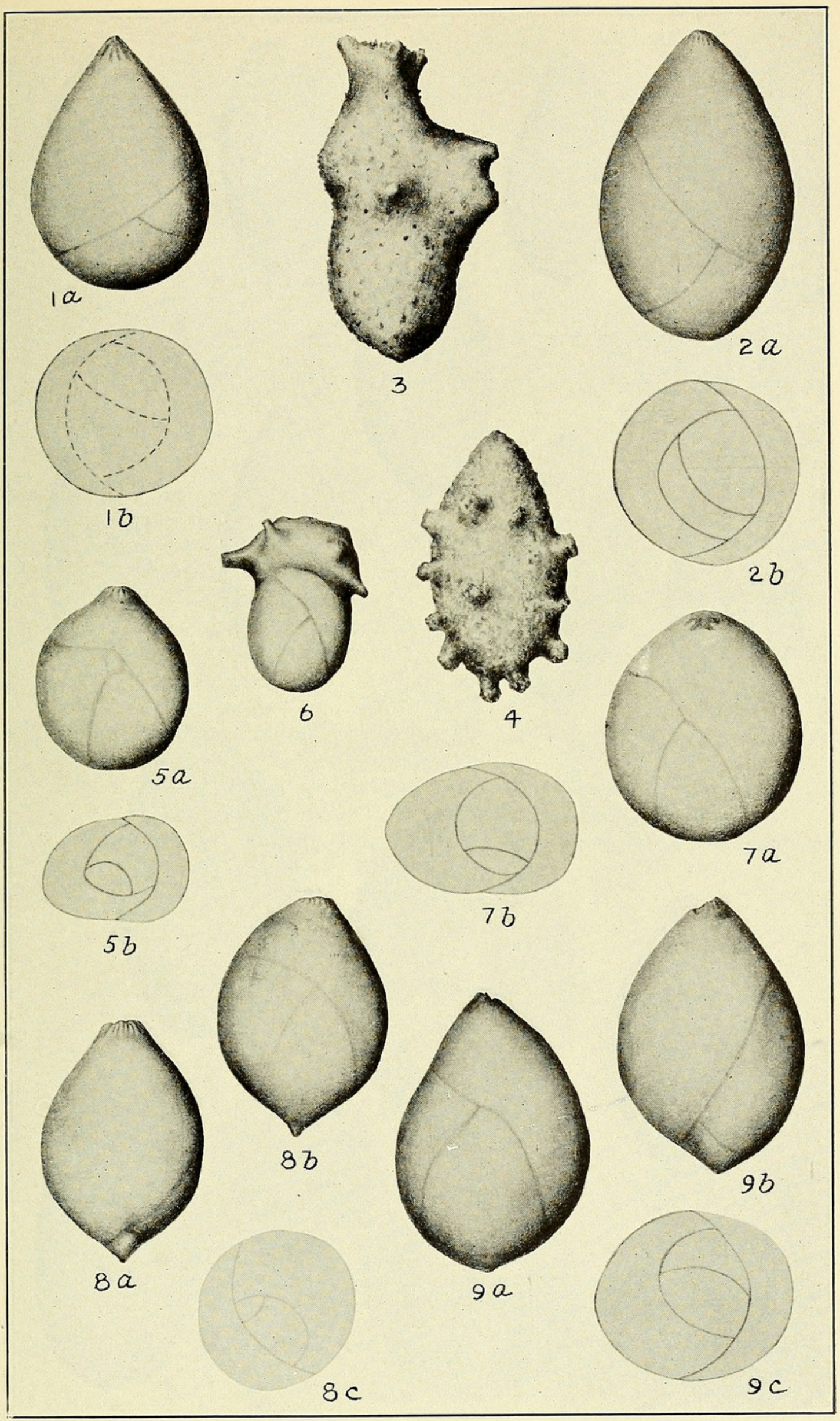

FORAMINIFERA OF THE FAMILY POLYMORPHINIDAE

FOR EXPLANATION OF PLATE SEE PAGE 164. 


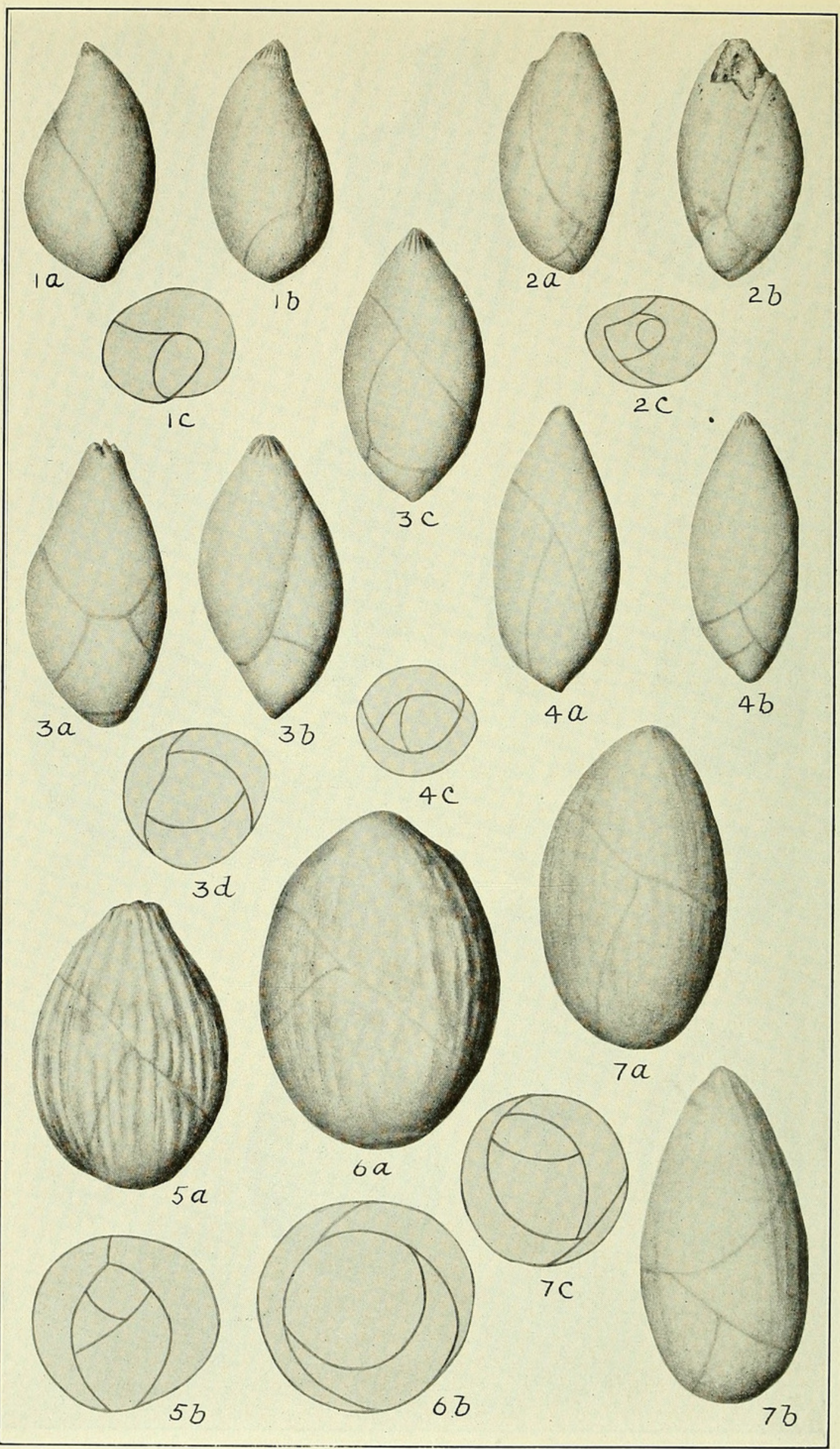

FORAMINIFERA OF THE FAMILY POLYMORPHINIDAE

FOR EXPLANATION OF PLATE SEE PAGE 165. 


\section{Plate 20}

FIg. 1. Globulina flexa Cushman and Ozawa. $\times 45$. Upper Oligocene, Doberg, near Bünde, Germany. $a, b$, side views; $c$, basal view.

2. Globulina exserta (Berthelin). $\times 45$. Cretaceous, chalk marl, Folkestone, England. $a, b$, side views; $c$, basal view.

3, 4. Globulina minuta (Roemer). $3, \times 45$. Oligocene, Düsseldorf, Germany. $4, \times 65$. Middle Oligocene, Hermsdorf, near Berlin, Germany.

5. Globulina granulosa Egger. $\times 45$. Miocene, Burdigalien inferieur, Moulin de l'Eglise, Saucats, France.

6. Globulina gibba d'Orbigny var. myristiformis (Williamson). 80. Beach, Lido, Venice, Italy. $a$, side view; $b$, basal view.

7. Globulina granulosa Egger (?). $\times 45 . \quad$ Miocene, Burdigalien, St. Paul de Dax, near Bordeaux, France. $a, b$, side views; $c$, basal view. 


\section{$2 \mathrm{BHL}$ Biodiversity Heritage Library}

1930. "A monograph of the Foraminiferal family Polymorphinidae, recent and fossil." Proceedings of the United States National Museum 77(2829), 1-185.

View This Item Online: https://www.biodiversitylibrary.org/item/100823

Permalink: https://www.biodiversitylibrary.org/partpdf/41030

\section{Holding Institution}

Smithsonian Libraries

\section{Sponsored by}

Biodiversity Heritage Library

\section{Copyright \& Reuse}

Copyright Status: Public domain. The BHL considers that this work is no longer under copyright protection.

This document was created from content at the Biodiversity Heritage Library, the world's largest open access digital library for biodiversity literature and archives. Visit BHL at https://www.biodiversitylibrary.org. 